Florida International University FIU Digital Commons

$11-15-2006$

\title{
Synthesis of multisubstituted halo-olefins via Pd- catalyzed cross-coupling reactions : applications in nucleoside chemistry
}

Daniela Andrei

Florida International University

DOI: $10.25148 /$ etd.FI14032316

Follow this and additional works at: https://digitalcommons.fiu.edu/etd

Part of the Chemistry Commons

\section{Recommended Citation}

Andrei, Daniela, "Synthesis of multisubstituted halo-olefins via Pd-catalyzed cross-coupling reactions : applications in nucleoside chemistry" (2006). FIU Electronic Theses and Dissertations. 1287.

https://digitalcommons.fiu.edu/etd/1287 
FLORIDA INTERNATIONAL UNIVERSITY

Miami, Florida

SYNTHESIS OF MULTISUBSTITUTED HALO-OLEFINS VIA PD-CATALYZED

CROSS-COUPLING REACTIONS. APPLICATIONS IN NUCLEOSIDE CHEMISTRY

A dissertation submitted in partial fulfillment of the

requirements for the degree of

DOCTOR OF PHILOSOPHY

in

CHEMISTRY

by

Daniela Andrei 
To: Interim Dean Mark Szuchman

College of Arts and Sciences

This dissertation, written by Daniela Andrei, and entitled Synthesis of Multisubstituted Halo-olefins via Pd-catalyzed Cross-coupling Reactions. Applications in Nucleoside Chemistry, having been approved in respect to style and intellectual content, is referred to you for judgment.

We have read this dissertation and recommend that it be approved.
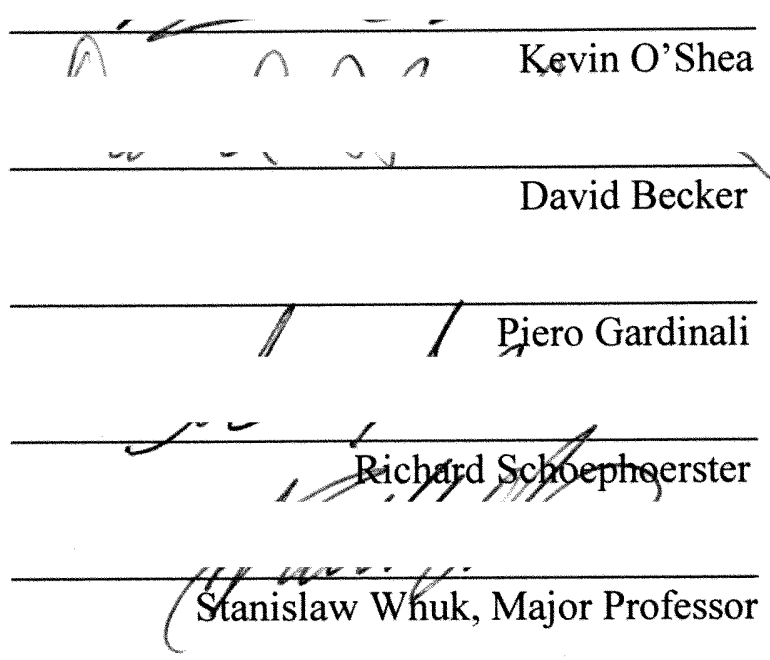

Date of Defense: November 15, 2006

The dissertation of Daniela Andrei is approved.

Interim Dean Mark Szuchman

College of Arts and Sciences

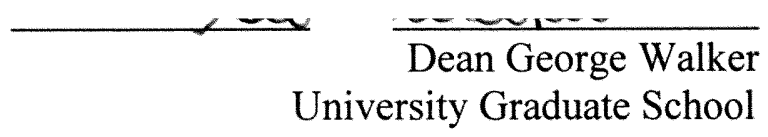

Florida International University, 2006 


\section{DEDICATION}

To Geanina, Bogdan, Viorel and my parents. 


\section{ACKNOWLEDGMENTS}

I will be forever grateful of my major professor, Dr. Stanislaw F. Wnuk, for all the valuable experience and knowledge that I have acquired as a graduate student in his lab. His dedication and enthusiasm to teach, support and encourage me through all these years are deeply appreciated.

I also would like to extend my gratitude to my committee members: Dr. O'Shea, Dr. Becker, Dr. Gardinali and Dr. Schoephoerster for their guidance and suggestions. I am also very thankful of Dr. Lees for all his help and kindness. Many thanks also go to Dr Wnuk's entire group who has offered me their friendship.

Most importantly, I would like to thank God for his never ending blessing. 


\begin{abstract}
OF THE DISSERTATION
SYNTHESIS OF MULTISUBSTITUTED HALO-OLEFINS VIA PD-CATALYZED

CROSS-COUPLING REACTIONS. APPLICATIONS IN NUCLEOSIDE CHEMISTRY

by
\end{abstract}

Daniela Andrei

Florida International University, 2006

Miami, Florida

Professor Stanislaw Wnuk, Major Professor

The enzyme $S$-adenosyl-L-homocysteine (AdoHcy) hydrolase effects hydrolytic cleavage of AdoHcy to adenosine (Ado) and L-homocysteine (Hcy). The cellular levels of AdoHcy and Hcy are critical because AdoHcy is a potent feedback inhibitor of crucial transmethylation enzymes. Also, elevated plasma levels of Hcy in humans have been shown to be a risk factor in coronary artery disease.

On the basis of the previous finding that AdoHcy hydrolase is able to add the enzyme-sequestered water molecule across the 5',6'-double bond of (halo or dihalohomovinyl)-adenosines causing covalent binding inhibition, we designed and synthesized AdoHcy analogues with the $5^{\prime}, 6^{\prime}$-olefin motif incorporated in place of the carbon-5, and sulfur atoms. From the available synthetic methods we chose two independent approaches: the first approach was based on the construction of a new C5'C6' double bond via metathesis reactions, and the second approach was based on the formation of a new $\mathrm{C} 6$ ' $-\mathrm{C} 7$ ' single bond via Pd-catalyzed cross-couplings.

Cross-metathesis of the suitably protected 5'-deoxy-5'-methyleneadenosine with racemic 2-amino-5-hexenoate in the presence of Hoveyda-Grubb's catalyst followed by standard 
deprotection afforded the desired analogue as $5^{\prime} E$ isomer of the inseparable mixture of $9^{\prime} R / S$ diastereomers. Metathesis of chiral homoallylglycine [(2S)-amino-5-hexenoate] produced AdoHcy analogue with established stereochemistry $E$ at $\mathrm{C}^{\prime}$ 'atom and $S$ at C9' atom. The 5'-bromovinyl analogue was synthesized using the brominationdehydrobromination strategy with pyridinium tribromide and DBU.

Since literature reports on the Pd-catalyzed monoalkylation of dihaloalkenes $\left(\mathrm{Csp}^{2}-\mathrm{Csp}^{3}\right.$ coupling) were scarce, we were prompted to undertake model studies on Pdcatalyzed coupling between vinyl dihalides and alkyl organometallics. The 1-fluoro-1haloalkenes were found to undergo Negishi couplings with alkylzinc bromides to give multisubstituted fluoroalkenes. The alkylation was trans-selective affording pure $Z$ fluoroalkenes. The highest yields were obtained with $\mathrm{PdCl}_{2}(\mathrm{dppb})$ catalyst, but the best stereochemical outcome was obtained with less reactive $\mathrm{Pd}\left(\mathrm{PPh}_{3}\right)_{4}$. Couplings of 1,1dichloro-and 1,1-dibromoalkenes with organozinc reagents resulted in the formation of monocoupled 1-halovinyl product. 
1. INTRODUCTION

1.1. S-Adenosyl-L-Homocysteine Hydrolase ……................................................... 1

1.1.1. Biological Functions of S-Adenosyl-L-Homocysteine Hydrolase .................... 1

1.1.2. Mechanism of $S$-Adenosyl-L-Homocysteine Hydrolase Action ....................... 4

1.1.3. Hydrolytic Activity of AdoHcy Hydrolase with Halovinyl Adenine ................. 7

1.1.4. Hydrolytic Activity of AdoHcy Hydrolase with Halohomovinyl Adenine

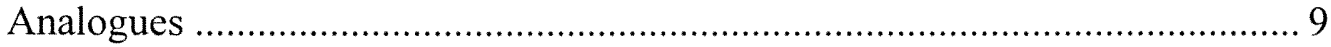

1.2. The Alkene - Metathesis Reaction ................................................................... 14

1.2.1. Introduction into the Alkene - Metathesis Reaction ...................................... 14

1.2.2. Metathesis Reaction in Nucleoside Chemistry ............................................. 19

1.3. Palladium-Catalyzed Cross-Coupling Reactions ................................................ 24

1.3.1. Introduction to Pd-catalyzed Cross-Coupling Reaction.................................. 24

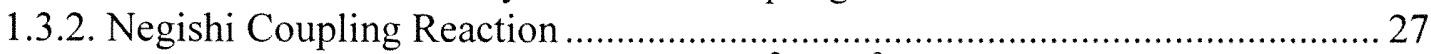

1.3.3. Negishi Cross-Couplings Involving $\mathrm{Csp}^{2}-\mathrm{Csp}^{3}$ Centers. ................................ 30

1.3.4. Negishi Cross-Couplings with Dihalovinyl Derivatives.................................. 33

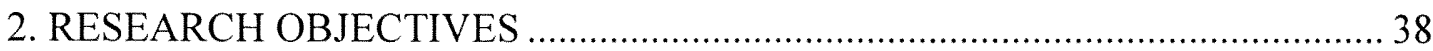

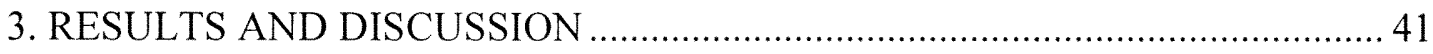

3.1. Are L-Adenosine and Its Derivatives Substrates for S-Adenosyl-L-

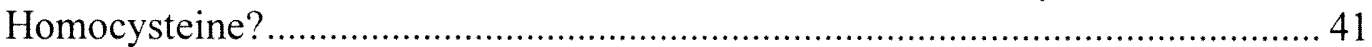

3.1.1. Synthesis of L-Adenosine and L-Adenosine 5'-Oximes. .............................. 41

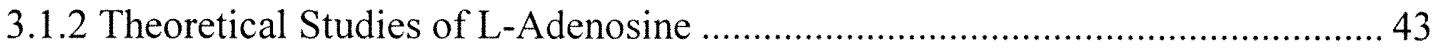

3.1.2.1. Computational Results with L-Adenosine ................................................ 43

3.1.2.2. Docking of L-Adenosine to the Closed Structure of AdoHcy

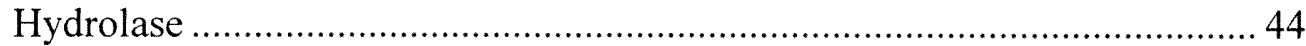

3.1.3. Interaction of AdoHcy Hydrolase with L-Adenosine ................................... 45

3.2. Design and Synthesis of S-Adenosylhomocysteine Analogues with the Sulfur and C5' Atoms Replaced by the Vinyl Unit........................................ 46

3.2.1. Metathesis Approach between the 5'-Deoxy-5'- Methyleneadenosine and the Racemic Homoallylglycine Precurosors. ......................................... 47

3.2.2. Metathesis Approach between the 5'-Deoxy-5'-Methyleneadenosine and the Chiral Homoallylglycine Precursors. ............................................... 53

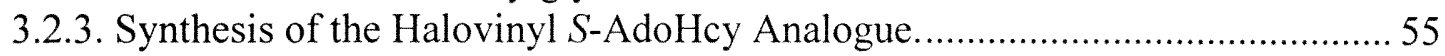

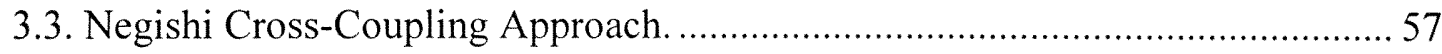

3.3.1. Couplings with 1-Fluoro-1-Haloalkenes..................................................... 57

3.3.2. Couplings with 1,1-Dichloro- and 1,1-Dibromoalkenes................................ 65

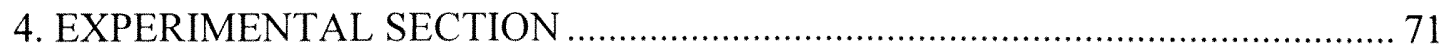

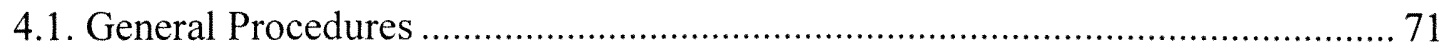

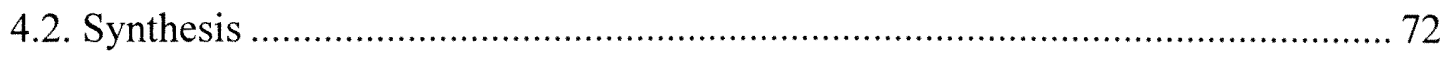




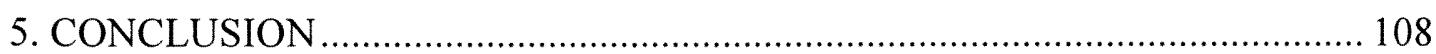

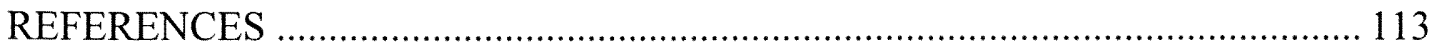

VITA 


\section{LIST OF FIGURES}

FIGURE

PAGE

1. The Mechanism of $S$-adenosyl-L-Homocysteine Hydrolase. .................................. 5

2. Selected Inhibitors of the AdoHcy Hydrolase ....................................................... 8

3. The 6'-Halo(vinyl)homoadenosine and Related Aristeromycin Analogues............ 9

4. The Selected Vinyl and Homovinyl Analogues of Ado and HomoAdo.................12

5. The Dihalo-Vinylhomoadenosine Analogues................................................... 13

6. Possible Mechanism by which 6'-Bromo-6'-Fluoro(homovinyl)adenosine Inactivates AdoHcy Hydrolase.

7. Commonly Used Metathesis Catalysts. ……..................................................... 18

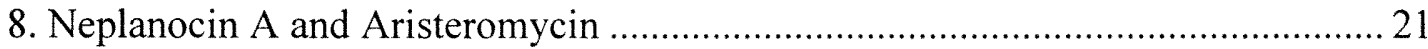

9. A General Catalytic Cycle for Pd-Catalyzed Cross-Coupling Reactions. .............. 26

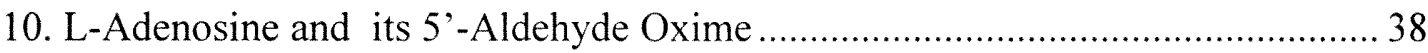

11. List of Chemical Structures for Chemicals............................. 111 


\section{LIST OF SCHEMES}

SCHEME

PAGE

1. The Role of AdoHcy Hydrolase in Regulating AdoMet Dependent Biological Methylation.

2. Mechanism of Inactivation of AdoHcy Hydrolase by EDDFHA ......................... 11

3. Types of Olefin Metathesis Reactions …………............................................. 15

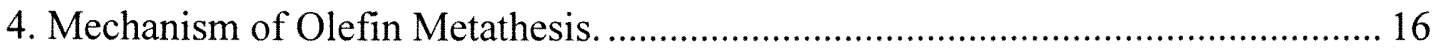

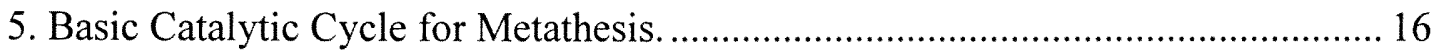

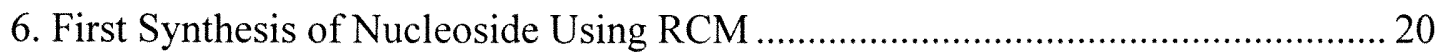

7. Synthesis of the Carbocyclic Analogue of Ribavirin Using RCM ........................20

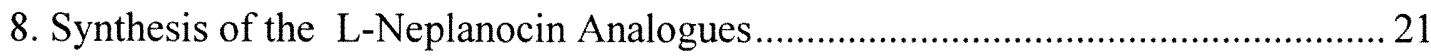

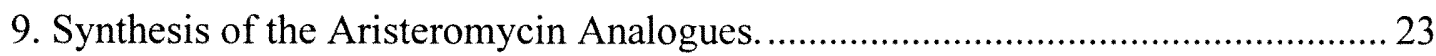

10. Synthesis of the Acyclic Nucleosides via Cross-Metathesis Reaction ................. 24

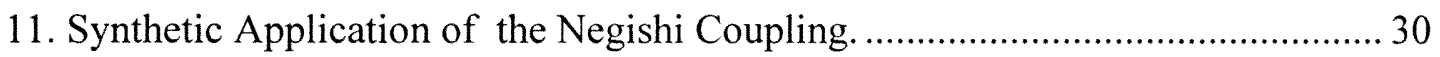

12. Negishi Cross-Couplings of the Alkyl Electrophiles under "Ligandless" Condition................................................................. 31

13. The Pd-Catalyzed Alkyl-Alkenyl Coupling with an Alkylzinc in a Total Synthesis of (-) -Discodermolide ..................................................................... 32

14. Negishi Cross-Couplings of Aryl and Vinyl Chlorides with Alkylzincs............... 33

15. Pd-Catalyzed Double-Alkylation of $\beta, \beta$-Dichlorostyrene................................. 34

16. Pd-Catalyzed Trans-Selective Monoalkylation of 1,1-Dichloro-1-Alkenes and

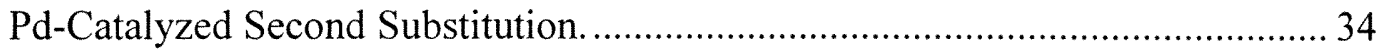

17. Pd-Catalyzed Trans-Selective Monoalkylation of 1,1-Dichloro-1-Alkenes with Alkylzinc Reagents. 
18. Putative Mechanism for the Competitive Formation of the Monoand Dialkylation Products.

19. Cross-Coupling of the Internal Z-Chloroalkenes with Grignard Reagents in the Presence of Pd Catalysts Containing Bulky Trialkylphosphines.

20. Retrosynthetic Analysis of the AdoHcy Analogues. 39

21. Synthesis of the L-Adenosine and L-Adenosine 5'-oximes. 42

22. Retrospective Analysis for the Unsaturated S-Adenosyl-L-Homocysteine Analogues.

23. Synthesis of the Protected 5'-Deoxy-2',3'-O-Isopropylidene-5'-Methylene Adenosine Precursors.

24. Synthesis of the Amino Acid Precursors for Metathesis Approach. 50

25. Cross-Metathesis between 5'-Deoxy-5'-Methyleneadenosine and Unsaturated $N$-Boc or $N$-Benzoyl Protected Amino Acids.

26. Enantioselective Hydrolysis of the Alkenyl- $\alpha$-Amino Acid Ester......................... 54

27. Cross-Metathesis of Adenosine Precursor with $S$-Amino Acid Derivative.......... 55

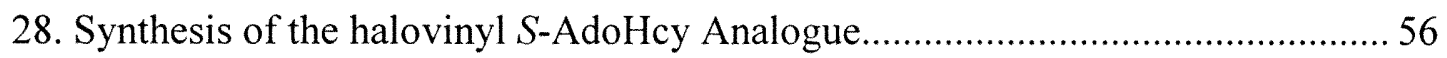

29. Stereoselective Synthesis of 1-Fluoro-1-Haloalkenes. ........................................... 58

30. Couplings of 1-Fluoro-1-Haloalkenes with Alkylzincs.......................................5 59

31. Effect of the Pd Catalyst on the Efficiency of Negishi Coupling ........................ 63

32. Establishing the Stereochemistry of Couplings with 1,1-Dihaloalkenes.............. 63

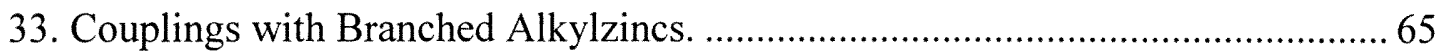

34. Synthesis of 1,1-Dichloro- and 1,1-Dibromoalkenes.............................................6 66

35. Screening of Pd Catalyst for the Monoalkylation Reaction...................................67

36. Pd-Catalyzed Trans-Selective Monoalkylation of 1,1-Dichloro- and 1,1Dibromoalkenes with Alkylzinc Reagents. 68 


\section{INTRODUCTION}

\subsection{S-Adenosyl-L-homocysteine hydrolase}

\subsubsection{Biological functions of $S$-adenosyl-L-homocysteine hydrolase}

The normal cellular role of $S$-Adenosyl-L-homocysteine hydrolase (AdoHcy hydrolase) is regulating $S$-Adenosyl-L-methionine (AdoMet) dependent biological methylation reactions (Scheme 1). ${ }^{1}$ AdoMet is involved in the methylation of many biomolecules, from small molecular weight neurotransmitters (e.g., histamine) to macromolecules (e.g., proteins, nucleic acids) and the various methyltransferases which catalyze these reactions have themselves been targets for drug design. ${ }^{2,3}$ AdoMet is also decarboxylated by AdoMet decarboxylase to dcAdoMet. S-Adenosyl-L-homocysteine (AdoHcy) is the byproduct of these methylation reactions and functions as a feedback inhibitor of these methyltransferases. Alteration of the cellular AdoMet/AdoHcy ratio results in serious perturbation of biological methylation of viral RNA. ${ }^{4}$ AdoHcy hydrolase provides the only known mechanism for AdoHcy catabolism in eukaryotes, catalyzing its hydrolysis to adenosine (Ado) and L-homocysteine (Hcy). Although the in vitro reaction favors the synthetic direction, subsequent metabolic conversions of adenosine and homocysteine within the cell assure the reaction will run in the hydrolytic direction. ${ }^{5}$

The cellular enzyme $S$-Adenosyl-L-homocysteine hydrolase effects hydrolytic cleavage of AdoHcy to give Ado and Hcy (Scheme 1). ${ }^{4,6}$ AdoHcy hydrolase plays a significant role in controlling the intracellular level of Hcy that is a cystathionine synthetase- catalyzed precursor to cysteine and methionine. The metabolism of AdoHcy by this enzyme is the only known source of Hcy in mammalian cells. ${ }^{7}$ The elevated 
plasma Hcy levels in humans have been demonstrated to be a risk factor for coronary artery disease in clinical studies. ${ }^{8}$ Inhibitors of AdoHcy hydrolase have the potential to reduce the risk of developing coronary heart disease by lowering the cellular level of Hcy. Although, supplementation with B-vitamins and folic acid has been shown to be effective in lowering plasma Hcy level in homocysteinemia patients with residual activity of cystathionine synthetase $\mathrm{e}^{8 \mathrm{~b}, 9}$, inhibitors of AdoHcy hydrolase have also the potential to regulate plasma level of Hcy. ${ }^{8}$
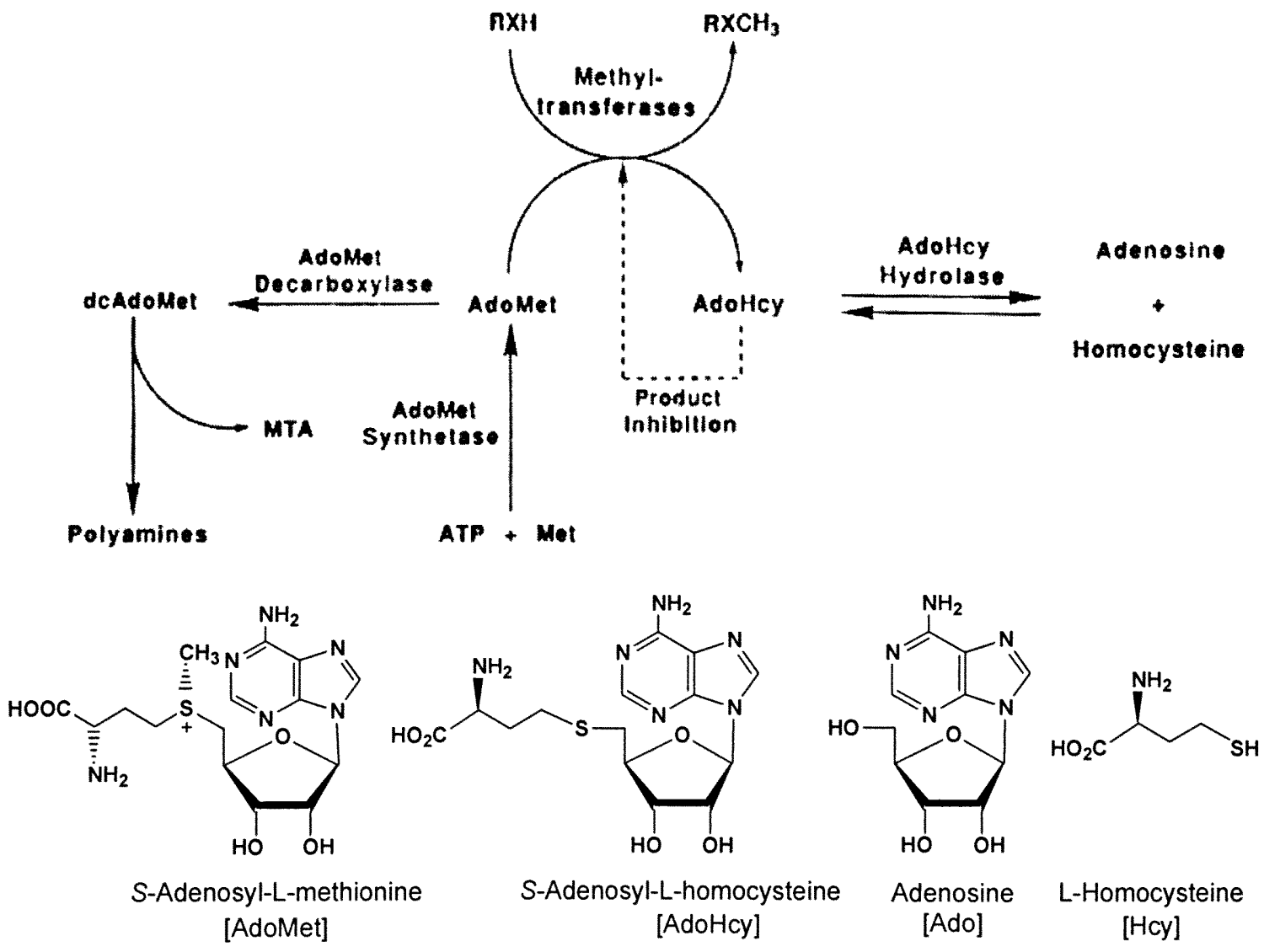

Scheme 1. The Role of AdoHcy hydrolase in regulating AdoMet dependent biological methylation. 
Study of the distribution of AdoHcy hydrolase in various mammalian tissues revealed that the enzyme activity was highest in the liver, kidney and pancreas; intermediate in the spleen and low in brain and heart. ${ }^{4}$ The liver of the mouse contains around twelve times more AdoHcy hydrolase than the kidney, which in turn has five times more AdoHcy than the brain. A one molar equivalent of copper is bound per subunit of mouse liver enzyme. ${ }^{10}$ In copper-deficient mice there was a $45 \%$ decrease in the hepatic level of AdoHcy. ${ }^{11}$ The binding of copper by enzyme means that there is a role for its involvement in copper metabolism.

AdoHcy hydrolase has attracted attention as a target for drug design $n^{6,12,13}$ because inhibitors of this enzyme are known to exhibit antiviral ${ }^{13,14,15}$, antiparasitic ${ }^{16}$, antiarthritic $^{17}$ and immunosuppressive effects ${ }^{18}$. Inhibition of the cellular AdoHcy hydrolase results in an intracellular build-up of AdoHcy, giving rise to an increase in the intracellular AdoHcy/AdoMet ratios and the subsequent inhibition of fundamental AdoMet dependent methylation reactions. The relationships established are particularly well recognized for the antiviral effect of AdoHcy. De Clercq and Cools found a linear relationship between the $\log \mathrm{IC}_{50}$ values (concentration which inhibits vaccinia virus replication by $50 \%$ ) and their $\log K_{\mathrm{i}}$ values (inhibition potency of AdoHcy hydrolase) for a series of AdoHcy hydrolase inhibitors. ${ }^{13}$

AdoHcy hydrolase inhibitors are potent as well as broad-spectrum antiviral agents, inhibiting the replication of a variety of (-) RNA viruses and double-stranded RNA viruses. ${ }^{13 a}$ This type of inhibitors are not particularly active against (+) RNA viruses or DNA viruses, except for vaccinia and African swine fever viruses. ${ }^{13 a .19}$ Their wide range of activity is in contrast to almost all clinically used nucleoside antiviral drugs, which are 
usually specific toward a particular species or strain of virus. ${ }^{6 a}$ Broad-spectrum antiviral drugs offer many advantages over narrow-spectrum agents; it is often difficult in clinical diagnoses to identify a viral pathogen in a short time. For instance in acute infections, viral chemotherapy must start as soon as the patient presents clinical symptoms. Thus, the development of broad-spectrum antiviral drugs is highly desired.

\subsubsection{Mechanism of $S$-adenosyl-L-homocysteine hydrolase action}

The mechanism by which AdoHcy hydrolase catalyzes the conversion of AdoHcy to Ado and Hcy (Figure 1) was established by Palmer and Abeles. ${ }^{20}$ The first step in the enzymatic reaction involves oxidation of the 3'-hydroxyl group of AdoHcy by the enzyme-bound $\mathrm{NAD}^{+}\left(\mathrm{E} \cdot \mathrm{NAD}^{+}\right)$to form $\mathrm{E} \cdot \mathrm{NADH}$ and 3'-keto-AdoHcy (oxidative activity of the enzyme). The 3'-keto group increases the acidity of the C-4' proton, allowing for abstraction of this proton by a base in the active site of the enzyme. Subsequently, $\beta$-elimination of Hcy results in the formation of the intermediate 3'-keto4',5'-didehydro-5'-deoxyAdo, (KDDA). Michael type addition of water (hydrolytic activity of the enzyme) to the 5' position of KDDA affords 3 '-ketoAdo, which is then reduced by the enzyme bound $\mathrm{NADH}$, resulting in the formation of Ado and regenerating the $\mathrm{NAD}^{+}$form of the enzyme. Palmer and Abeles also found that 4',5'-didehydro-5'deoxyadenosine, DDA is an alternative substrate of the enzyme and its oxidation at C3' gave enone KDDA directly. Isotopes studies ${ }^{21,22}$ and also general kinetic studies ${ }^{23 a}$ reinforced this mechanism. ${ }^{20}$

Porter and Boyd showed that neither the apoenzyme nor the reduced form of AdoHcy hydrolase $(\mathrm{E} \cdot \mathrm{NADH})$ was catalytically active. ${ }^{23 b}$ The mechanism suggests that breakage of the C5'-S bond (elimination of the Hcy from 3'-keto-AdoHcy) and the 
formation of $\mathrm{C} 5$ '-O bond (addition of water to the KDDA) were dependent on the oxidative activity of the enzyme. Parry and Askonas studied the stereochemistry ${ }^{22}$ of this reaction and found a syn geometry of the addition of Hcy to KDDA. Thus, the overall reaction catalyzed by AdoHcy hydrolase occurs with retention of configuration at $\mathrm{C}^{\prime}$ '. It also follows that the elimination step is catalyzed by an enzyme which also exhibits a syn geometry.
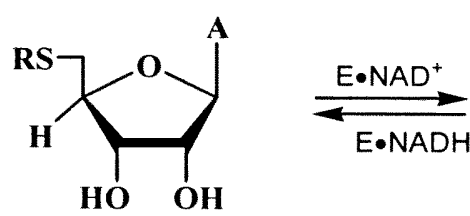

HO
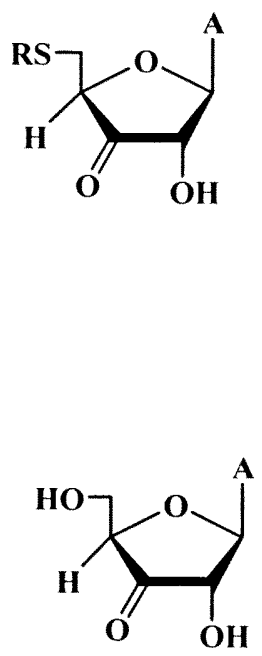
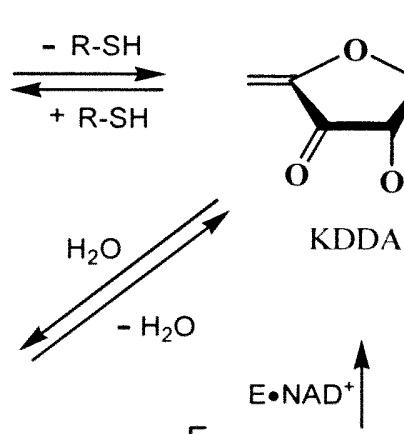

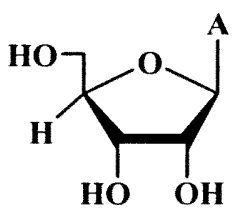

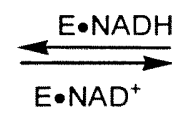

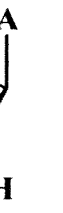


However, Borchardt and his coworkers have demonstrated that these two catalytic activities of AdoHcy hydrolase can be considered independent of each other. ${ }^{25}$ Borchardt et al. defined type I-mechanism-based inhibitors of AdoHcy hydrolase as inhibitors that serve as substrates for "oxidative" activities of the enzyme. These inhibitors are oxidized to the 3'-keto derivatives and they convert the enzyme from its active form $\left(\mathrm{NAD}^{+}\right)$to its inactive form (NADH) (cofactor depletion mechanism). A striking feature of all these first-generation AdoHcy hydrolase inhibitors is the similarity in their broad-spectrum antiviral activity, indicating a common mechanism of action. The type II-mechanismbased inhibitors of AdoHcy hydrolase were defined as inhibitors which use the "oxidative" and/or the "hydrolytic" activity of the enzyme to produce electrophiles on the active site, which in turn react with the protein nucleophiles to modify the enzyme (covalent inactivation mechanism). ${ }^{6 \mathrm{~b}, 12 \mathrm{a}, 24,26}$ These second-generation AdoHcy hydrolase inhibitors have added to the body of evidence indicating that inhibition of this enzyme results in the inhibition of viral replication. Finally, type III inhibitors are those that use neither the "oxidative" nor the "hydrolytic" activity, but they are reversibly bound to the enzyme. $^{12 \mathrm{a}, 26}$

The X-ray crystal structure of a substrate-bound NADH form of human AdoHcy hydrolase has been determined. ${ }^{27}$ In this crucial experiment the pure NAD ${ }^{+}$-form of the enzyme was inactivated with 9-(2,3-dihydroxycyclopent-4-en-1-yl)adenine [DHCeA], to give crystal of the 3'-ketoDHCeA/NADH form of human AdoHcy suitable for X-ray crystallographic analysis. The sequestered water molecules at the active site were found to be hydrogen bounded to His55, Asp131 and His301. The water molecule seems to have a dual role in the catalytic mechanism. It is not only the sole candidate for the 
catalytic base responsible for the $\mathrm{H}^{\prime}$ ' abstraction initiating Hcy elimination but it may also add to the intermediate enone in the formation of 3 '-ketoAdo. ${ }^{266,27} \mathrm{~A}$ crystal structure of AdoHcy hydrolase from rat liver in the substrate-free $\mathrm{NAD}^{+}$form shows an open catalytic site in the absence of substrate. ${ }^{28}$ This identified Glu55 as a proton acceptor from the 3'-OH during the abstraction of the $\mathrm{H}^{\prime}$ ' by $\mathrm{NAD}^{+}$and His54 or Asp130 as general acid-base catalyst. The Cys194 was proposed to modulate the oxidation state of the bound $\mathrm{NAD}^{+}$. However, these two crystal structures do not define clearly the binding site for the homocysteine moiety of AdoHcy at the active site of the enzyme.

\subsubsection{Hydrolytic activity of AdoHcy hydrolase with halovinyl adenine analogues}

Various adenosine analogs and adenine carboxylic nucleosides have been shown to be potent inhibitors of AdoHcy hydrolase (Figure 2) ${ }^{6 a, 12 b, 13 a, 29,30}$ Many of these compounds are type I mechanism-based inhibitors of AdoHcy hydrolase, ${ }^{6 a, 12 b}$ which inactivate the enzyme by reducing the enzyme-bound $\mathrm{NAD}^{+}$to $\mathrm{NADH}$. In the process of inactivation, the inhibitor is oxidized stoichiometrically to the corresponding $3^{\prime}$-keto nucleoside. ${ }^{6 \mathrm{a}, 12 \mathrm{~b}}$

McCarthy and co-workers synthesized vinyl fluoride analogs of 4',5'-didehydro-5'deoxyadenosine as potential mechanism-based inhibitors. ${ }^{31}$ Of the vinyl fluorides synthesized, (Z)-4',5'-didehydro-5'-deoxy-5'-fluoroadenosine (ZDDFA, 1, Figure 2) was

shown to be the most potent inhibitor of AdoHcy hydrolase. ${ }^{31}$ In addition to being a potent inhibitor, ZDDFA was of interest mechanistically because it was first reported as a 
type II mechanism-based inhibitor (reduce the $\mathrm{E} \cdot \mathrm{NAD}^{+}$to $\mathrm{E} \cdot \mathrm{NADH}$ and release fluoride ion quantitatively).
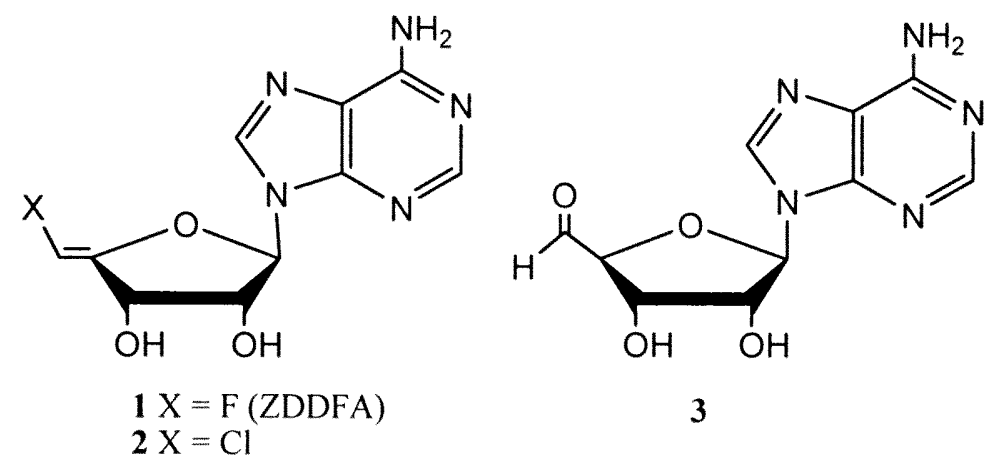

Figure 2. Selected inhibitors of AdoHcy hydrolase.

Borchardt and his coworkers have demonstrated that vinyl fluoride $\mathbf{1}$ is not a type II inhibitor but rather a "pro-inhibitor" that is converted by the hydrolase into adenosine 5'aldehyde 3 (and its epimer) which inactivates the enzyme by the type I mechanism. The "hydrolytic" activity of AdoHcy hydrolase removes the fluoride anion from $\mathbf{1}$ by addition-elimination process. It was proved that the "hydrolytic" activity of the enzyme was independent of its "oxidative" activity. ${ }^{66.25}$ The Ado-5'-aldehyde 3 was independently synthesized and shown to be equally potent inhibitor of AdoHcy hydrolase. $^{32}$ The 5'-chloromethylene analog 2 was found to be a time-dependent inactivator of the AdoHcy with potency comparable to that of its 5'-fluoromethylene analogue $1 .^{33,34}$ 


\subsubsection{Hydrolytic activity of AdoHcy hydrolase with halohomovinyl adenine Analogues}

The AdoHcy hydrolase is also capable of adding water across the isolated 5',6'double bond of the 6'-halo(vinyl)homoAdo derivative $4^{35,36}$ (Figure 3). The synthesis of homovinyl halides $4^{36,37,38}$ was based on the vinyl sulfones and organotin chemistry developed by Wnuk and others. The 6'-halo(vinyl) homoAdo analogues 4 were found to be concentration and time dependent inactivators of AdoHcy hydrolase. The inhibition potencies were correlated with anticancer and antiviral activities of $\mathbf{4}$ and it was found to be in the order of $\mathrm{I}>\mathrm{Br}>\mathrm{Cl}>\mathrm{F}$ (and $E>Z) .{ }^{36}$

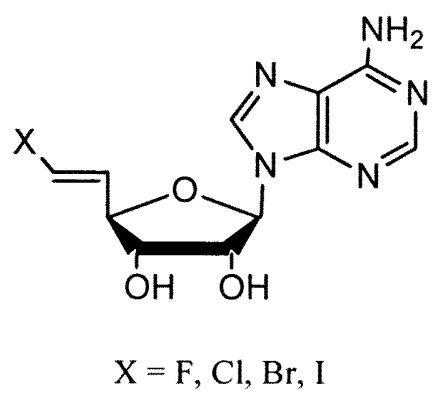

4

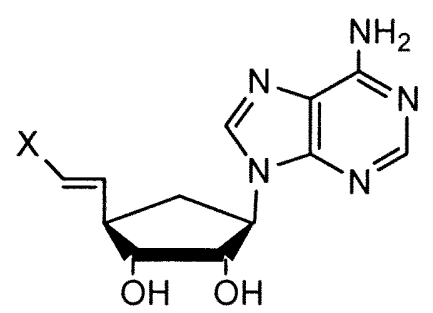

$\mathrm{X}=\mathrm{F}, \mathrm{I}$

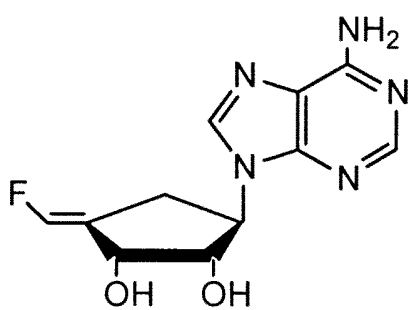

6

Figure 3. The 6'-halo(vinyl)homoadenosine and related aristeromycin analogues.

Surprisingly, AdoHcy hydrolase possesses the catalytic power to effect addition of water to the isolated double bond of 4 . Scheme 2 shows the mechanism by which the fluorine derivative, (E)-5',6'-didehydro-6'-deoxy-6'-fluoro-homoadenosine (EDDFHA) 4 is processed by AdoHcy hydrolase. The reaction was shown to proceed by three pathways: pathway a, water attack at the 6'-position of EDDFHA and elimination of fluoride ion results in the formation of homoadenosine 6'-carbox-aldehyde (HACA), which degrades chemically to form Ade; pathway b, water attack at the 5' position of EDDFHA results in 
the formation of 6'-deoxy-6'-fluoro-5'-hydroxyhomoadenosine (DFHHA) and pathway c, oxidation of EDDFHA results in the formation of the NADH form of the enzyme (inactive form) and 3'-keto-EDDFHA, which could react with water at either the C5' or C6' positions. The partition ratios among the three pathways were determined to be $\mathrm{k}_{3^{\prime}} \cdot \mathrm{k}_{6^{\prime}}: \mathrm{k}_{5^{\prime}}=1: 29: 79$, with one lethal event (enzyme inactivation) occurring every 108 nonlethal turnovers. ${ }^{36 \mathrm{~b}}$

To eliminate ribosyl ring cleavage during inhibition of AdoHcy hydrolase by 4, the 6'halo (vinyl) homoaristeromycin derivatives 5 (Figure 3) were prepared in which the furanosyl ring oxygen was replaced by a methylene unit. ${ }^{39}$ This type of modification was expected to provide analogues that could not suffer cyclopentanyl ring cleavage by $\beta$ elimination ( $\mathrm{H}^{\prime}$ ' and the ring oxygen $\mathrm{O}^{\prime}$ ') as observed for homoadenosine 6'-aldehyde (HACA, Scheme 2). Inactivation of AdoHcy hydrolase by $5(X=F)$ involved addition of water at the vinyl $\mathrm{C}^{\prime}$ ' or $\mathrm{C}^{\prime}$ ' (with elimination of fluoride) and oxidation of $\mathrm{C} 3$ '. The partition ratio among three pathways were found to be: $\mathrm{k}_{3}{ }^{\circ} \mathrm{k}_{6}{ }^{\circ} \mathrm{k}_{5},=1: 1.7: 0.6$.

The 4',5'-didehydro-5'-deoxy-5'-fluoroaristeromycin 6 was also synthesized (Figure 3) and it was found not to be a substrate for the hydrolytic activity of the enzyme since incubation of AdoHcy hydrolase with $\mathbf{6}$ did not result in the release of fluoride ion. ${ }^{40 a}$ However, independently synthesized aristeromycin 5'-aldehyde as well as 6 were found to be potent type I inhibitors. ${ }^{40}$ It is possible that enzyme-mediated protonation of the ribosyl ring oxygen of $\mathbf{1}$ (as well 4) enhances the electrophilicity of the C5', making the 5 ' position more susceptible to attack by the enzyme-bound water. 

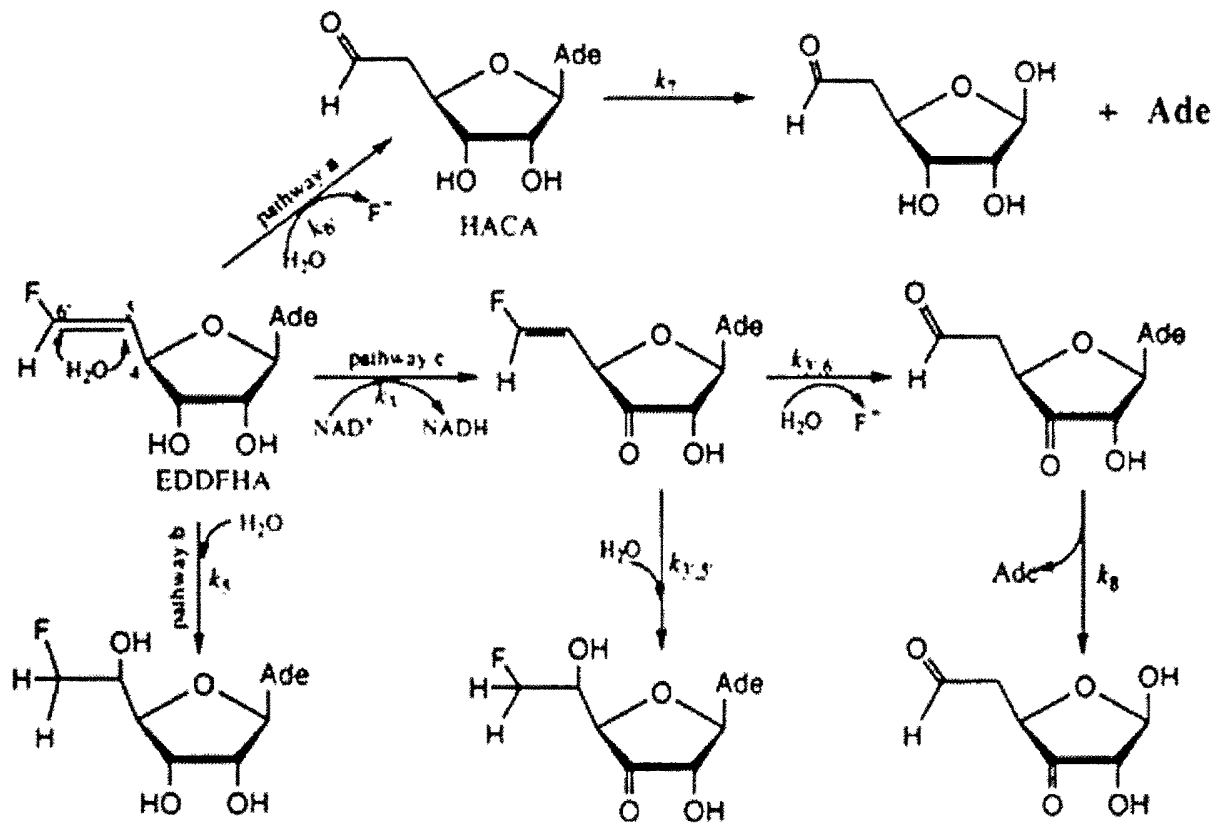

Scheme 2. Mechanism of inactivation of AdoHcy hydrolase by EDDFHA

To probe "pure" hydrolytic activity of the AdoHcy hydrolase, analogues of vinyl halides 1 and 4 without an oxidizable function (hydroxyl group) at C3'have been targeted. $^{41}$ The 3'-deoxy modification gave halovinyl analogue 7 and halohomovinyl analogue 10 with greater differences in stereoelectronic effects and lack of a hydrogenbond acceptor at C3' (Figure 4). In other series, the 3'-hydroxyl group was replaced with fluoro 8 or chloro 9 substituents to give a closer stereoelectronic analogue to the natural substrates, but still preventing the oxidative activity at $\mathrm{C} 3$ '. The $3^{\prime}-$ modified analogues 7 10 were found to be weak inhibitors of AdoHcy in a sharp contrast to the 3'-hydroxy analogues 1 and $\mathbf{4}$. They were not substrates for the "hydrolytic" activity of the enzyme. ${ }^{41}$ Thus, it is secure to conclude, that the 3'-hydroxyl group is essential for effective 
inhibitors/substrate binding to AdoHcy hydrolase, and such binding is required for execution of the "hydrolytic" activity of the enzyme.

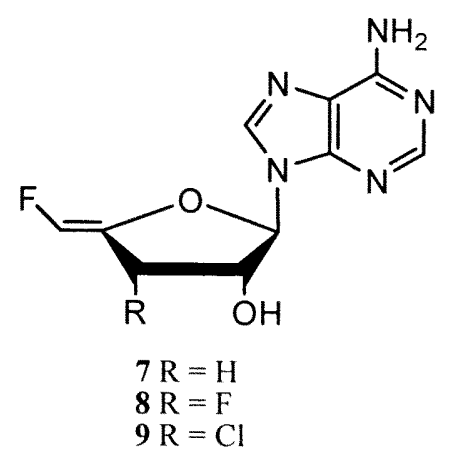

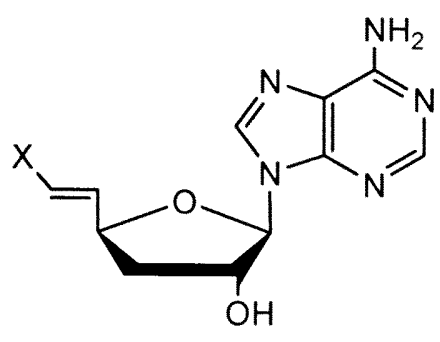

$10 \mathrm{R}=\mathrm{I}, \mathrm{Br}, \mathrm{F}$

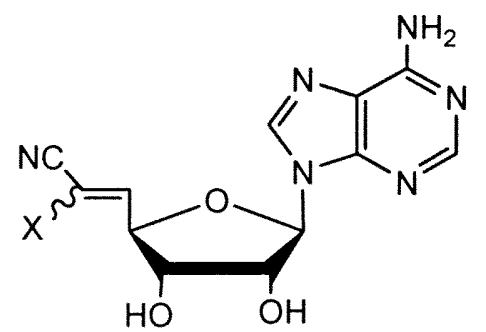

$11 \mathrm{X}=\mathrm{H}$

$12 \mathrm{X}=\mathrm{Cl}$

Figure 4. The selected vinyl and homovinyl analogues of Ado and homoAdo.

Recently, 6'-cyano-5',6'-didehydro-6'-deoxyhomoadenosine $11^{30}$ and 6'-chloro6'-cyano-5',6'-didehydro-6'-deoxyhomoadenosine $12^{30}$ were also synthesized and tested as new mechanism-based inhibitors of AdoHcy hydrolase (Figure 4). Nucleoside (E)-11 was identified as a type I inhibitor of the enzyme, whereas inactivation of the enzyme by nucleoside $(Z)-\mathbf{3}$ and $(E)$-12 was accompanied by the formation of a covalent labeling of AdoHcy hydrolase.

The geminal and vicinal (dihalo)homovinyl analogues 13-15 were also designed as potential new substrates for the hydrolytic activity of AdoHcy hydrolase. (Figure 5). ${ }^{42}$ These types of analogues were found to be the first examples of type II (covalent) inhibitors that are activated by the "hydrolytic" activity of the enzyme without prior oxidation at $\mathrm{C} 3$ '. 


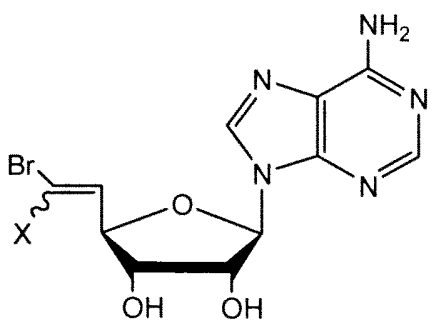

$13 \mathrm{X}=\mathrm{F}$

$14 \mathrm{X}=\mathrm{Br}$

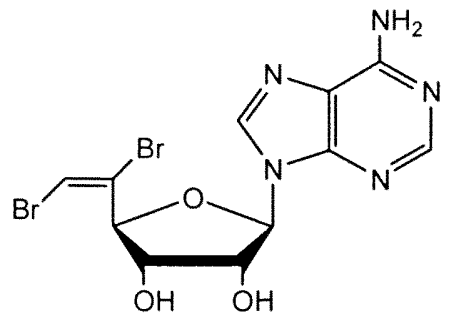

15

Figure 5. The dihalo-vinylhomoadenosine analogues.

Inactivation of the enzyme with [bromo(fluoro)] homovinyl analogue $\mathbf{1 3}$ was shown to be concentration and time-dependent and resulted in covalent linkage between the enzyme and the inhibitor with concomitant release of halide ions $\left(\mathrm{F}^{-}\right.$and $\mathrm{Br}^{-43}$. The enzyme-mediated addition of water to $\mathbf{1 3}$ at $\mathrm{C}^{\prime}$ ' of the 5',6'-double bond (followed by elimination of bromide ion) generates an electrophilic acyl fluoride 16 (Figure 6). Nucleophilic attack by a proximal Arg 196- $\mathrm{NH}_{2}$ group forms a covalent adduct 17 (lethal event). The enzyme maintains its original $\mathrm{NAD}^{+} / \mathrm{NADH}$ content indicating no oxidation

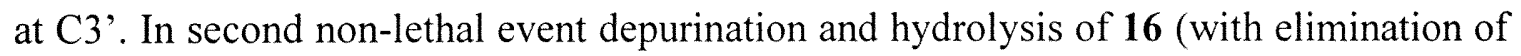
fluoride ion) produced hexose-derived 6-carboxylic acid. ${ }^{43}$

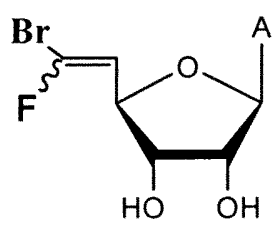

13

.
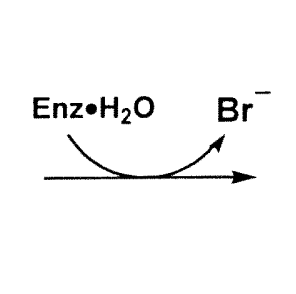

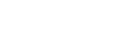




\subsection{The Alkene-metathesis reaction}

\subsubsection{Introduction into the alkene - metathesis reaction}

Olefin metathesis reaction is a unique carbon skeleton redistribution in which unsaturated carbon-carbon bonds are rearranged in the presence of metal carbine complexes. ${ }^{44}$ With the advent of efficient catalyst, this reaction has emerged as a powerful tool for the formation of carbon-carbon bonds in organic chemistry. ${ }^{45}$ In fact, with the exception of palladium-catalyzed cross-coupling reactions, no other group of reactions has had such a profound impact on the formation of carbon-carbon bonds in the last quarter of a century. ${ }^{46}$ The number of applications of this reaction has dramatically increased in the past few years. Of particular significance, this type of reaction utilizes no additional reagents beyond a catalytic amount of metal carbine and the only other product from the reaction is, in most cases, a volatile olefin, such as ethylene. ${ }^{45}$ The history of alkene metathesis is a fascinating one, beginning with its unexpected discovery nearly 50 years ago through the design and application of the latest initiators available today. ${ }^{44 b, 47}$

There are several classes of olefin metathesis reactions (Scheme 3). In the cross-metathesis reaction $(\mathrm{CM})$ a mixtures of products are obtained unless a volatile byproduct (ethylene) is produced that can be removed from the reaction mixture. Ring closing metathesis (RCM) is favored for the production of unstrained rings and is driven both entropically and by the elimination of a volatile alkene. Ring opening metathesis (ROM) is only favored at very high olefin concentration, or more commonly with strained olefins. The same general features will hold true for the polymerization reactions. 

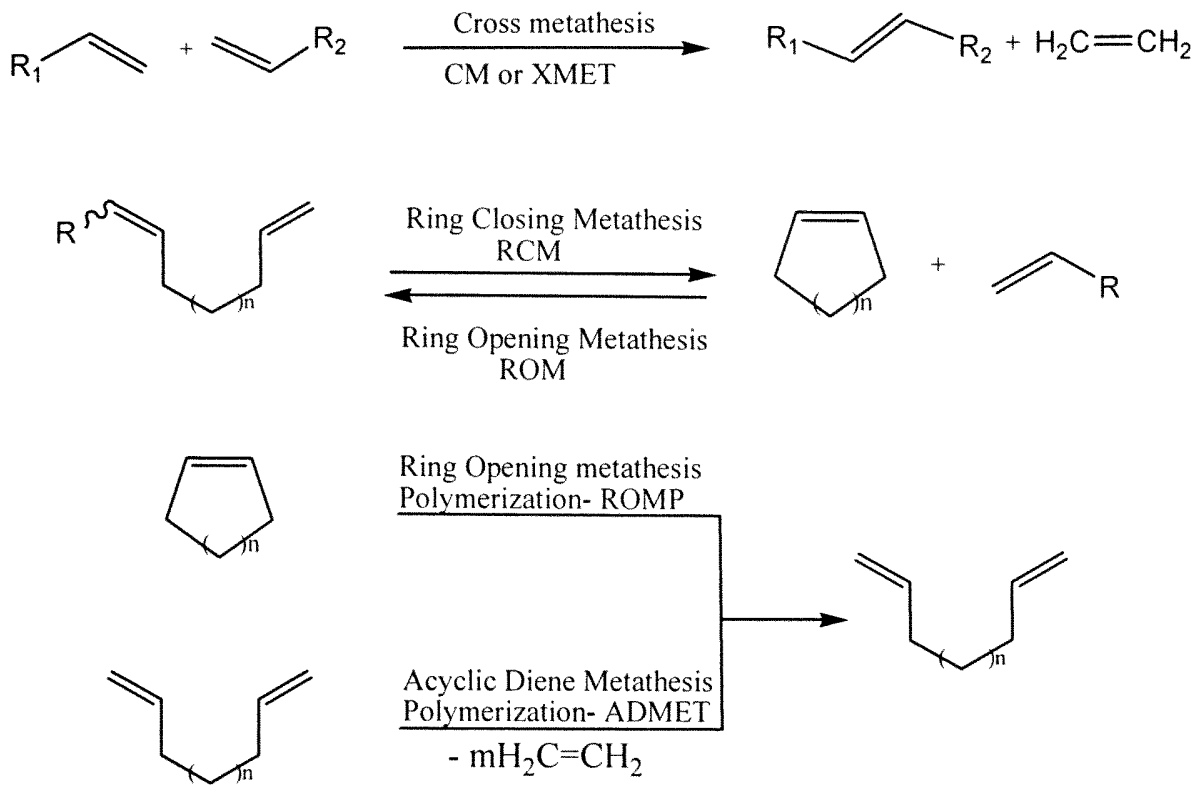

Scheme 3. Types of olefin metathesis reactions

The elucidation of the mechanistic pathway was, itself, the culmination of nearly two decades of extensive research by numerous groups, and the subject of lively debate in the literature during that time. The generally accepted mechanism of alkene metathesis was originally proposed by Herisson and Chauvin ${ }^{48}$ in 1971 with key experimental evidence for its validity subsequently being provided by the Casey ${ }^{49}, \mathrm{Katz}^{50}$ and Grubbs groups $^{51}$, and invokes metal carbine intermediates as key propagating species in the catalytic cycle. Chauvin proposed that olefin metathesis involves interconversion of an olefin and a metal alkylidene. This process is believed to occur via a metal-cyclobutane intermediate by alternating $[2+2]$ cycloadditions and cycloreversions (Scheme 4$)$. The basic catalytic cycle for metathesis is depicted in scheme 5 . 

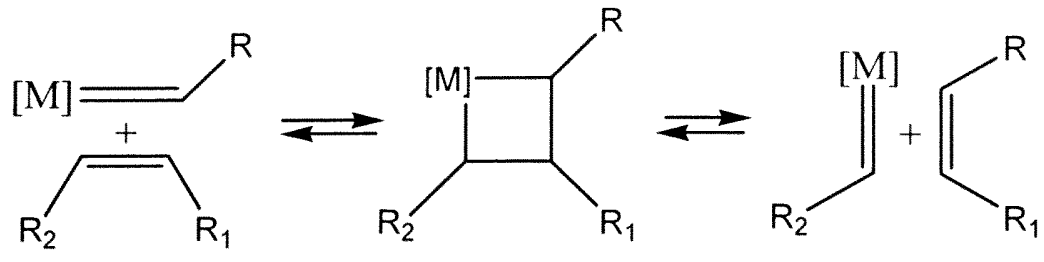

Scheme 4. Mechanism of olefin metathesis.

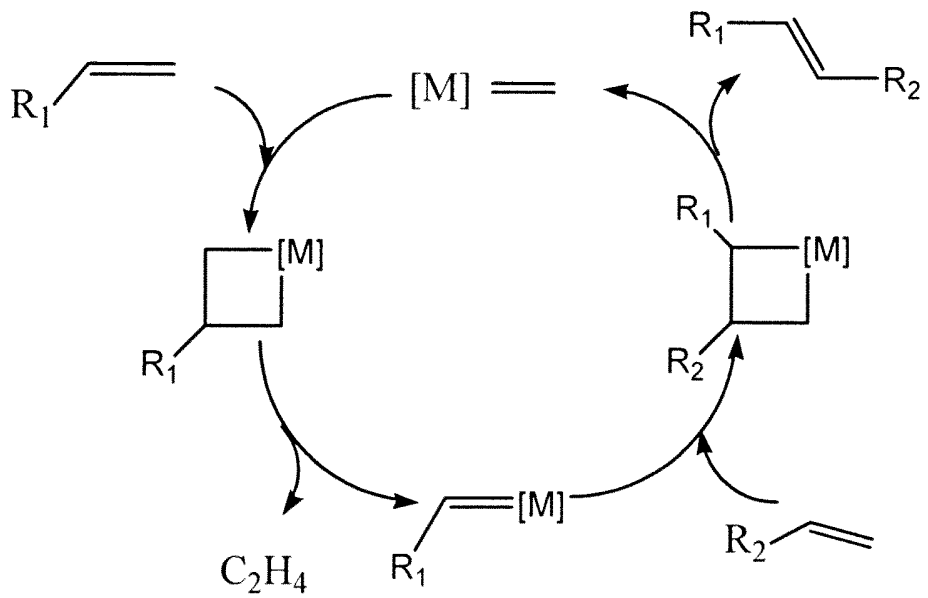

Scheme 5. Basic catalytic cycle for metathesis.

The success of the alkene-metathesis reaction and the many stunning and ingenious situations in which it has been applied are largely due to the advent of today's readily available catalyst systems that display high activity and excellent functionalgroup tolerance. ${ }^{46}$ Some of typical metathesis catalyst which are commercially available are shown in Figure 7. 
The molybdenum-based catalyst (Schrock catalyst) was introduced by the Schrock group ${ }^{52}$ and represented the first real groundbreaking advance in catalyst design since the tungsten carbenes initially used by Katz. ${ }^{53}$ Schrock catalyst displays excellent metathesis activity with a variety of alkene substrates and it is particularly useful for the formation of sterically crowded systems. The only drawback of this catalyst is its pronounced sensitivity to oxygen, moisture and certain polar or protic functional groups owing to the electrophilicity of the high-oxidation-state transition-metal center. ${ }^{54}$

Grubbs and co-workers subsequently introduced ruthenium-based carbene complexes. ${ }^{55}$ The ruthenium reacts preferentially with carbon-carbon double bonds over most other functional groups which makes these ruthenium-catalysts unusually stable towards alcohols, amides, aldehydes and carboxylic acids. ${ }^{56}$ Because of this aspect, it is possible to increase the functional group tolerance of an olefin metathesis catalyst by focusing on a transition metal, such as ruthenium. ${ }^{56}$

The first and second generation Grubbs catalyst exhibit much greater functionalgroup tolerance than the Schrock catalyst. The Hoveyda-Grubbs catalyst shows efficiencies similar to those of Grubbs catalyst second generation but with a different substrate specificity. The exchange of the $\mathrm{PCy}_{3}$ ligand with the isopropyl ether leads to different reactivities. For instance, in contrast to Grubbs second generation catalyst, which proved to be an excellent catalyst for yne-ene $\mathrm{CM}$, analogous reaction with Hoveyda-Grubbs second generation catalyst yielded only traces of the desired products. Polymerisation of the alkyne component was not observed. Substantial differences in terms of reactivity were found also in RCM reactions. The recyclable catalyst is unique in catalyzing RCM, ROMP and CM reactions with highly electron-deficient substrates. ${ }^{57}$ 
<smiles>CCc1cccc(C(C)C)c1N=C(N=CC(C)(C)c1ccccc1)OC(C)(C(F)(F)F)C(F)(F)F</smiles>

Schrock catalyst<smiles>CC(C)(C)[R](Cl)(Cl)C=Cc1ccccc1</smiles>

Grubbs first generation catalyst

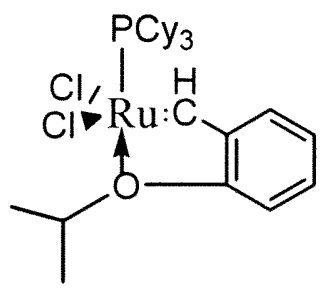

Hoveyda-Grubbs first generation catalyst<smiles>Cc1cc(C)c(N2CCN(c3c(C)cc(C)cc3C)C2[Z10](Cl)(Cl)[P-](Cl)(Cl)Cl)c(C)c1</smiles>

Grubbs second generation catalyst

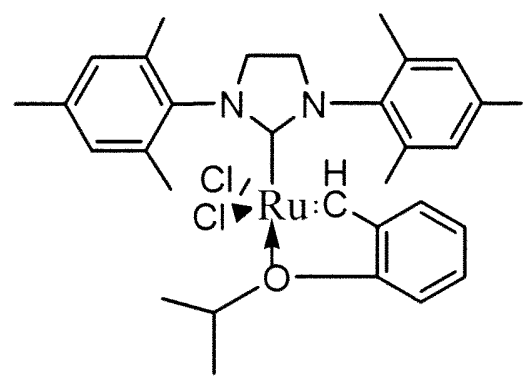

Hoveyda-Grubbs second generation catalyst

Figure 7. Commonly used metathesis catalysts. 


\subsubsection{Metathesis reaction in nucleoside chemistry}

The intense search for clinically useful nucleoside derivatives has resulted in a wealth of new approaches to their synthesis. In this context, the olefin metathesis reaction $^{45,47 b, 58,59}$ has emerged over the past decade as a powerful reaction that has fundamentally changed the outlook on nucleoside chemistry.

Historically, the first synthesis of nucleoside analogues using metathesis was achieved in 1996 by Crimmins and King ${ }^{60}$ utilizing chiral (S)-4-benzyl-2-oxazolidinones through a strategy combining three key transformations: (1) an asymmetric aldol addition to establish the relative and absolute configuration of the pseudosugar, (2) a ring-closing metathesis (RCM) to construct the carboxylic ring and (3) a Trost-type palladium(0) substitution to introduce the heterocyclic base (Scheme 6). The cyclisation by RCM of diene 22, was achieved in the presence of Grubbs first generation catalyst giving enantiomerically pure cyclopentenol $\mathbf{2 3}$ in $97 \%$ yield.

Kuang et al. ${ }^{61}$ have prepared the carbocyclic analogue of ribavirin 26 in a similar approach, starting from the anti-aldol $\mathbf{2 4}$, which then underwent a ring-closing metathesis in the presence of Grubbs first generation catalyst to yield 25 in $96 \%$ (Scheme 7). Further treatment of 25 with $\mathrm{LiBH}_{4} / \mathrm{MeOH} / \mathrm{THF}$ at $0^{0} \mathrm{C}$ followed by reaction with $m \mathrm{CPBA}$ gave the corresponding non-racemic epoxy diol. After protecting the hydroxyl groups, the resulting epoxide was reacted with triazole in the presence of $\mathrm{NaH}$ to give the desired ring-opening product as the major isomer. Then treatment with ammonia followed by hydrogenolytic deprotection provided carbocyclic ribavarin $\mathbf{2 6}$ in a moderate yield. 
<smiles>O=C1N[C@@H](Cc2ccccc2)CO1</smiles><smiles></smiles>

1. $n$-BuLi, THF, $-78^{\circ} \mathrm{C}$,

$\underset{\text { 2. } \mathrm{TiCl}_{4}(-) \text {-sparteine, }}{\stackrel{\mathrm{CH}_{2}=\mathrm{CH}\left(\mathrm{CH}_{2}\right)_{2} \mathrm{C}(\mathrm{O}) \mathrm{OPiv}}{\longrightarrow}}$ $\mathrm{CH}_{2} \mathrm{Cl}_{2}, \mathrm{R}-\mathrm{CH}=\mathrm{CH}-\mathrm{CHO}$

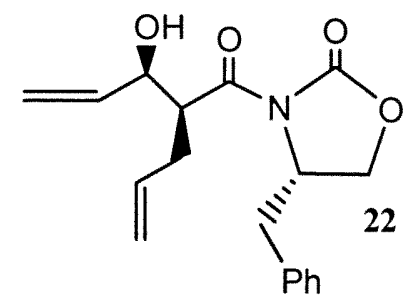

22

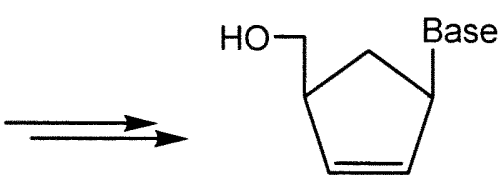

Scheme 6. First synthesis of nucleoside using RCM
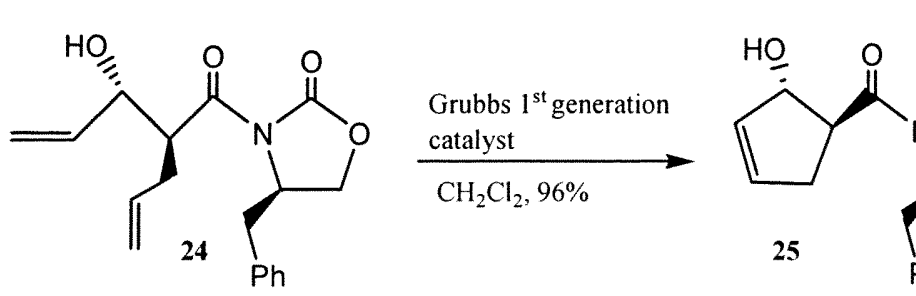

25<smiles>NC(=O)c1ncn(C2CC(CO)(CO)C(O)C2O)n1</smiles>

Scheme 7. Synthesis of carbocyclic analogue of ribavirin using RCM.

Among the nucleoside analogues prepared by metathesis approach, synthesis of neplanocins and aristeromycins analogues represent a major part of existing literature. Neplanocin A, 27, \{(-)-9-[trans-2',trans-3'-dihydroxy-4'-(hydroxymethyl)-cyclopent-4'enyl]adenine\}, (Figure 8), has a wide range of biological activities and it is a strong 
inhibitor of AdoHcy hydrolase. ${ }^{62}$ Analogs of L-neplanocins ${ }^{63} 32$ have been synthesized starting from methyl $\alpha$-D-galactopyranoside 28 as depicted in scheme 8 .<smiles>Nc1ncnc2c1ncn2C1C=C(CO)C(O)C1O</smiles>

Neplanocin A

27<smiles>Nc1ncnc2c1ncn2C1CC(CO)CC1O</smiles>

Aristeromycin

32<smiles>Nc1nccc2c1ncn2C1CC(O)C2COC21</smiles>

3-deaza-aristeromycin

33

Figure 8. Neplanocin A and Aristeromycin<smiles>COC1O[C@H](CO)[C@@H](O)[C@H](O)[C@H]1O</smiles>

28<smiles>C=C[C@H](OBr)[C@@H](OBr)[C@@H](OCc1ccccc1)C(=O)CBr</smiles>

29<smiles>C=C[C@@H](OCc1ccccc1)[C@@H](OCc1ccccc1)C(=C)COc1ccccc1</smiles>

30

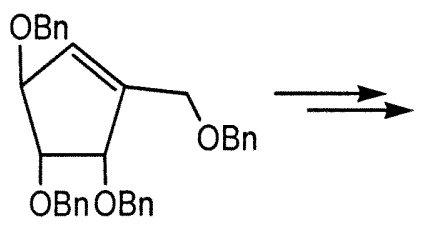

31<smiles></smiles>

32

Scheme 8. Synthesis of L-neplanocins analogues 
After benzylation and demethylation on the anomeric position of $\mathbf{2 8}$, reaction with methyltriphenyl phosphonium bromide and subsequent oxidation gave optically pure Ltagatose [L-lyxo-hexulose] as a single isomer. Oxidation of L-tagatose produced the ketoderivative 29. A second Wittig reaction on $\mathbf{2 9}$ afforded the $(+)$ diene $\mathbf{3 0}$ in $77 \%$ yield. The 1,6-hepta diene 30, which bears the three asymmetric centers of the final molecule, underwent $\mathrm{RCM}$ in the presence of Grubbs catalyst in refluxing benzene to give the cyclopentene derivative 31 in $90 \%$ yield. After removal of the benzyl group using sodium metal in liquid ammonia, the heterocycles were introduced under Tsuji-Trost allylic amination. Also, a synthesis of D-neplanocin has been realized by $\operatorname{Jin}^{64}$ through a similar approach, using a RCM, starting from protected D-ribose.

The naturally occurring carbocyclic nucleoside, aristeromycin 32, (Figure 8) is also known to be an inhibitor of AdoHcy hydrolase. Borchardt and his co-workers reported the synthesis of modified analogues of this compound ${ }^{65,66}$ using a nonmetathesis approach. Of the carbocyclic purine nucleosides tested, the most potent inhibitor of AdoHcy hydrolase were the carbocyclic adenosine (aristeromycin) itself and 3-deaza-carbocyclic adenosine $\mathbf{3 3}^{67}$ (Figure 9) both of which totally inhibited the enzyme at concentrations of $0.2 \mu \mathrm{M}$.

In most of cases, the aristeromycin analogues $\mathbf{4 0}$ have been synthesized involving the key cyclopentenone intermediate 39 (Scheme 9). The cyclopentenone intermediate is in fact a versatile starting point for the preparation of many other carbocyclic nucleosides. ${ }^{68,69}$ 


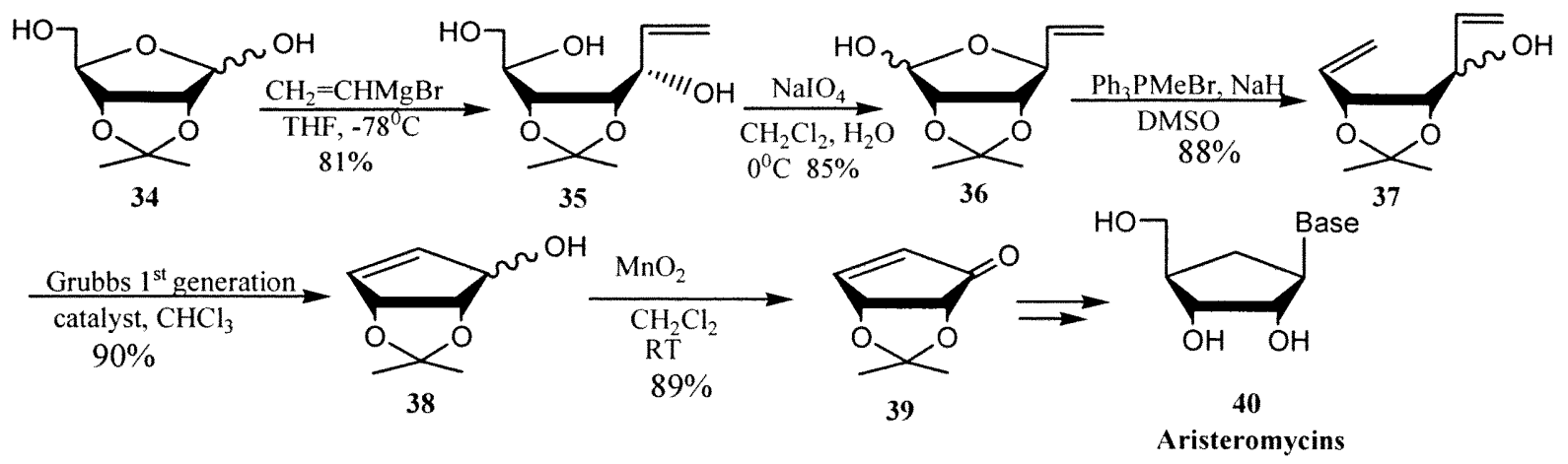

Scheme 9. Synthesis of the aristeromycin analogues.

Synthesis of the arysteromycin analogues started with the protected D-ribose $\mathbf{3 4}$ being treated with vinylmagnesium bromide to give triol 35 . Oxidative cleavage of triol 35 with sodium metaperiodate gave the lactol $\mathbf{3 6}$ in $85 \%$ yield. Wittig reaction of $\mathbf{3 6}$ with triphenylphosphonium methylidene afforded the diene 37. Ring closing-metathesis of diene 37 using Ru-Grubbs catalyst gave the allylic alcohol 38 (90\%) which was converted to the D-cyclopentanone 39 in $89 \%$ yield. In the following steps the cyclopentanone intermediate $\mathbf{3 9}$ is used in the synthesis of arysteromycins $\mathbf{4 0}{ }^{69}$

Agrofoglio and his co-workers ${ }^{58 \mathrm{~b}}$ reported a method for the synthesis of $E$ unsaturated acyclic nucleosides via a combination of palladium-catalyzed allylic alkylation and ruthenium-based cross-metathesis (CM). This approach provides an efficient and reliable route to new nucleoside analogues such as $\mathbf{4 3}$ (Scheme 10). Thus, the cross-metathesis (CM) of protected allylic diol $\mathbf{4 1}$ with allylic pyrimidine derivatives 42 was achieved by using Grubbs $2^{\text {nd }}$ generation catalyst. The tolerance of the ruthenium metathesis catalyst towards basic tertiary amines is less understood as most examples reported in literature use a deactivated nitrogen (amide, carbamate). ${ }^{58 b, 70}$ 


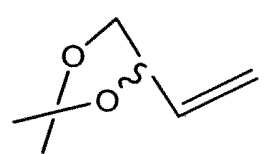

41<smiles>[X]c1cn(CC=C)c(=O)nc1[X]</smiles>

$\underset{\text { catalyst, } \mathrm{CH}_{2} \mathrm{Cl}_{2}}{\stackrel{\text { Grubbs } 2^{\text {nd }} \text { generation }}{\longrightarrow}}$

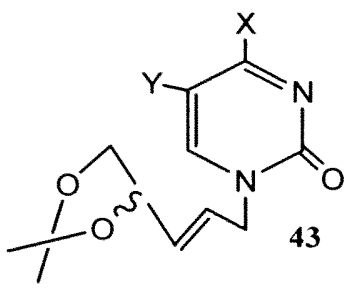

$\mathrm{X}=\mathrm{OH} ; \mathrm{NHBz}$

$\mathrm{Y}=\mathrm{H}, \mathrm{CH}_{3}, \mathrm{I}$

Scheme 10. Synthesis of acyclic nucleosides via cross-metathesis reaction

Less than a decade has elapsed since Crimmins ${ }^{60}$ reported the first use of metathesis reaction for nucleoside. From the work published by this time, it is apparent that metathesis has played and will most likely continue to play, a major role in the synthesis of new nucleosides.

\subsection{Palladium-catalyzed cross-coupling reactions}

\subsubsection{Introduction to $\mathbf{P d - c a t a l y z e d ~ c r o s s - c o u p l i n g ~ r e a c t i o n ~}$}

The palladium-catalyzed cross-coupling of an organometal $\left(R^{1} M\right)$ with an organic electrophile $\left(\mathrm{R}^{2} \mathrm{X}\right)$ has emerged over the past thirty years as one of the most general and selective methods for carbon-carbon bond formation (eq.1) ${ }^{71}$. Currently, it appears to be generally superior to related methods involving the use of $\mathrm{Ni}, \mathrm{Cu}$ of $\mathrm{Fe}$ catalysts in its scope and stereo-, regio- and chemoselectivities. ${ }^{72}$ The $\mathrm{R}^{1}$ group of $\mathrm{R}^{1} \mathrm{M}$ can be aryl, alkenyl, alkynyl, allyl, benzyl, alkyl, cyano, propargyl, enoxy; while the $\mathrm{R}^{2}$ group of $\mathrm{R}^{2} \mathrm{X}$ can be aryl, alkenyl, alkynyl, allyl, benzyl, propargyl, alkyl or acyl.

$$
\mathrm{R}^{1} \mathrm{M}+\mathrm{R}^{2} \mathrm{X} \stackrel{\mathrm{PdL} n(\text { cat })}{\longrightarrow} \mathrm{R}^{1}-\mathrm{R}^{2}+\mathrm{MX}
$$

Eq.1. Pd-catalyzed cross-coupling of an organometal $\left(R^{1} M\right)$ with an organic electrophile $\left(\mathrm{R}^{2} \mathrm{X}\right)$. 
The Pd-catalyzed cross-coupling can be performed with organometals containing any of these metals including $\mathrm{Zn}, \mathrm{Al}, \mathrm{Zr}, \mathrm{B}, \mathrm{Sn}, \mathrm{Li}, \mathrm{Mg}, \mathrm{In}, \mathrm{Si}, \mathrm{Cu}, \mathrm{Mn}$ (Table 1).

Taking the mechanism for organopalladium chemistry into account, several points should be addressed. Reactions involved in formation of organopalladium intermediates are done in the presence of phosphine ligands. These ligands coordinate at palladium and play an important role in the reaction by influencing the reactivity. One point is the relative weakness of the C-Pd bond and the instability of alkylpalladium species in which there is $\beta$-hydrogen. The transition metal-catalyzed coupling reactions occur in a sequence of: (a) oxidative-addition; (b) transmetallation (alkylation)/isomerization and (c) reductive- elimination. These three steps provide a powerful catalytic method for the new carbon-carbon bond formation (Figure 9). Transmetallation is the most characteristic of the cross-coupling reactions because this process combines the quality of the transition metal and the main group metal reagent. However, this step is also the one that is the least understood because of its highly dependence on the nature of organometallic reagents and the conditions of the reaction.

Table 1. Transition metal-catalyzed cross-coupling reactions

\begin{tabular}{|lll|}
\hline Name Reaction & $\mathbf{R}^{1} \mathbf{M}$ & $\mathbf{R}^{2} \mathbf{X}$ \\
\hline Kumada-Corriu & $\mathrm{R}^{1}-\mathrm{MgX}$ or $\mathrm{R}^{1}-\mathrm{Li}$ & aryl, alkenyl \\
\hline Suzuki-Miyaura & $\mathrm{R}^{1}-\mathrm{BR}_{2}^{\prime}$ & aryl, alkenyl, alkyl \\
\hline Negishi & $\mathrm{R}^{1}-\mathrm{ZnX}^{\prime} \mathrm{R}^{1}-\mathrm{AlX}, \mathrm{R}^{1}-\mathrm{ZrX}$ & aryl, alkenyl, alkynyl, acyl \\
\hline Hiyama & $\mathrm{R}^{1}-\mathrm{SiX}_{3}$ & triflates, alkenyl, aryl \\
\hline Stille & $\mathrm{R}^{-} \mathrm{Sn}(\mathrm{alkyl})_{3}$ & aryl, alkynyl, acyl \\
\hline
\end{tabular}


The coupling reaction begins with oxidative-addition of an electrophilic component to $\mathrm{Pd}$ catalyst. The $\mathrm{Pd}$ catalyst such as $\mathrm{Pd}\left(\mathrm{PPh}_{3}\right)_{4}, \mathrm{Pd}_{2}(\mathrm{dba})_{3}, \mathrm{PdCl}_{2}(\mathrm{dppb})$, with or without an extra ligand are used. The reaction rates and yields vary with the choice of $\operatorname{Pd}(0)$ or $\operatorname{Pd}(\mathrm{II})$ used. The stoichiometric ratio between palladium and ligand is aslo very important. Excess of phosphine retards the oxidative-addition step that is often the rate-determining step.

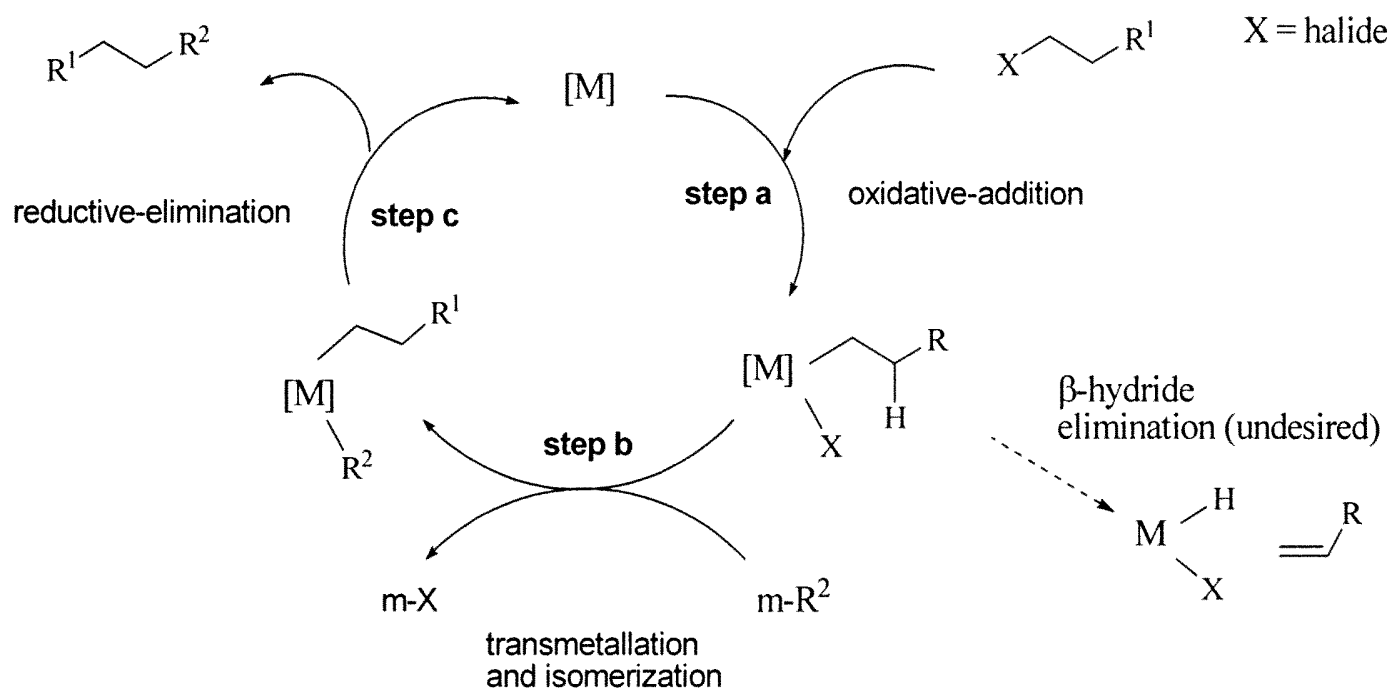

$[\mathrm{M}]=\mathrm{Pd}, \mathrm{Cu}, \mathrm{Ni}, \mathrm{Fe}, \mathrm{Rh} \ldots ; \mathrm{m}=\mathrm{Li}, \mathrm{Mg}, \mathrm{Zn}, \mathrm{B}, \mathrm{Al}, \mathrm{Si}, \mathrm{Cu}, \mathrm{Sn}, \mathrm{Zr} \ldots$

Figure 9. A general catalytic cycle for Pd-catalyzed cross-coupling reactions.

The most studies of the coupling reactions have been focused on forming of the $\mathrm{C}_{\mathrm{sp}}{ }^{2}$ $\mathrm{C}_{\mathrm{sp}}{ }^{2}$ and $\mathrm{C}_{\mathrm{sp}}-\mathrm{C}_{\mathrm{sp}}{ }^{2}$ bonds. There has been considerably less progress in developing effective cross-couplings involving $\mathrm{C}_{\mathrm{sp}}{ }^{3}$ centers with the exception of couplings between $\mathrm{C}_{\mathrm{sp}}{ }^{2}$ as electrophiles and $\mathrm{C}_{\mathrm{sp}}{ }^{3}$ as nucleophiles. ${ }^{73}$ Moreover, the monocross-coupling reactions of 1,1-dihalovinyl electrophiles with $\mathrm{C}_{\mathrm{sp}}{ }^{2}$ or $\mathrm{C}_{\mathrm{sp}}$ nucleophiles are less common ${ }^{74}$ and monocouplings between 1,1-dihalovinyl electrophiles and $\mathrm{C}_{\mathrm{sp}}{ }^{3}$ nucleophiles are 
scarced. ${ }^{72,75,76}$ Couplings of two $\mathrm{sp}^{3}$ centers of unactivated alkyls do not show much success due to the slow oxidative-addition of alkyl halides and the $\beta$-hydride elimination from organopalladium (II) intermediates. The final steps in Pd-mediated reactions are the elimination of Pd to form a carbon-carbon bond. Organopalladium species with two organic substituents show tendency to decompose with recombination of the organic groups by reductive elimination.

\subsubsection{Negishi coupling reaction}

In 1972, after the discovery of Ni-catalyzed coupling of alkenyl and aryl halides with Grignard reagents, it became apparent that in order to improve the functional group tolerance of the process, the organometallic coupling partners should contain less electropositive metals than lithium and magnesium. In 1976, E. Negishi and his coworkers reported the first stereospecific Ni-catalyzed alkenyl-alkenyl and alkenyl-aryl cross-coupling of alkenylalanes (organoaluminums) with alkenyl- and aryl halides. ${ }^{77,78}$ Extensive research by Negishi showed that the best results (reaction rate, yield, stereoselectivity) are obtained when organozincs are coupled in the presence of $\mathrm{Pd}(0)$ catalysts. $^{79,80,81}$ The Pd- or Ni-catalyzed stereoselective cross-coupling of organozincs and aryl, alkenyl, or alkynyl halides is known as the Negishi cross-coupling reaction (eq. 2). 


$$
\begin{aligned}
& \text { NiLn or PdLn } \\
& \mathrm{R}^{1}-\mathrm{X}+\mathrm{R}^{2}-\mathrm{Zn}-\mathrm{X} \\
& \text { catalytic } \\
& \text { solvent/ L (ligand) } \\
& \mathrm{R}^{1}-\mathrm{R}^{2} \\
& \text { coupled product } \\
& \mathrm{R}^{1}=\text { aryl, alkenyl, } \quad \mathrm{R}^{2}=\text { aryl, alkenyl, allyl, } \quad \mathrm{L}=\mathrm{PPh}_{3} \text {, dppe, dppp } \\
& \text { alkynyl, acyl benzyl, homoallyl, dppb, dppf, } \\
& \mathrm{X}=\mathrm{Cl}, \mathrm{Br}, \mathrm{I} \text {, OTf, OAc } \mathrm{X}=\mathrm{Cl}, \mathrm{Br}, \mathrm{I}
\end{aligned}
$$

Equation 2. Negishi cross-coupling reaction

The general features of the Negishi cross-coupling reaction are:

- both Ni and Pd-phosphine complexes work well as catalysts. However, Pd-catalyst tend to give somewhat higher yields and better stereoselectivity, and their functional group tolerance is better;

- the active catalysts are relatively unstable $\mathrm{Ni}(0)$ and $\mathrm{Pd}(0)$-complexes but these can be generated in situ from more stable $\mathrm{Ni}(\mathrm{II})$ and $\mathrm{Pd}(\mathrm{II})$-complexes with a reducing agent (e.g. 2 equiv. of DIBAL-H or $n$-BuLi);

- in the absence of the transition metal catalyst, the organozinc reagents do not react with the alkenyl halides to any appreciable extent;

- the most widely used ligand is $\mathrm{PPh}_{3}$, but other achiral and chiral phosphine ligands have been successfully used;

- the various organozinc reagents can be prepared by either direct reaction of the organic halide with zinc metal or activated zinc metal or by transmetallation of the corresponding organolithium of Grignard reagent with a zinc halide $\left(\mathrm{ZnX}_{2}\right)^{82,83}$; also many of organozinc reagents are commercially available; 
- the use of organozinc reagents allows for a much greater functional group tolerance in both coupling partners than in the Kumada cross-coupling where organolithiums and Grignard reagent are utilized as coupling partners.

- other advantages of the use of organozincs include: high reactivity, high regio- and stereoselectivity, wide scope and applicability, few side reactions and almost no toxicity; - the reaction is mostly used for coupling of two $\mathrm{C}\left(\mathrm{sp}^{2}\right)$ carbons but $\mathrm{C}\left(\mathrm{sp}^{2}\right)-\mathrm{C}(\mathrm{sp})$ as well $\mathrm{C}\left(\mathrm{sp}^{2}\right)-\mathrm{C}\left(\mathrm{sp}^{3}\right)$ are also well known;

- besides organozincs, compounds of $\mathrm{Al}$ and $\mathrm{Zr}$ can also be utilized;

- if the organoaluminium or organozirconium derivatives are not sufficiently reactive, they can be transmetallated by the addition of zinc salts, and this protocol is reffered to as the double metal catalysis; ${ }^{84}$

- of all the various organometals ( $\mathrm{Al}, \mathrm{Zr}, \mathrm{B}, \mathrm{Sn}, \mathrm{Cu}, \mathrm{Zn})$, organozincs are usually the most reactive in Pd-catalyzed cross-coupling reactions and do not require the use of additives (e.g. bases as in Suzuki coupling) to increase the reactivity. ${ }^{85}$

Some of the limitations of the Negishi cross-coupling reaction are: $\bullet$ propargylzincs do not couple well but homopropargylzincs do; $\bullet$ secondary and tertiary alkylzincs may undergo isomerization, but cross-couplings of primary alkyl- and benzylzincs give good results; $\bullet$ due to the high reactivity of organozincs, $\mathrm{CO}$ insertion usually does not happen unlike in the case of less reactive organotins (Stille cross-coupling).

The mechanism of the Negishi reaction follows the same pathway as the general catalytic cycle for the Pd-catalyzed cross-coupling reactions described above in section 1.3 .1 . 
The Negishi cross-coupling reaction has been widely utilized in organic synthesis. For instance, the Negishi reaction was used during the final stages of the total sythesis of Caerulomycin $\mathrm{C}$ for the preparation of the bipyridyl system by $\mathrm{T}$. Sammakia et $\mathrm{al}^{86}$ (Scheme 11). The highly substituted 6-bromopyridine was coupled, in the presence of the $\mathrm{Pd}_{2}(\mathrm{dba})_{3} / \mathrm{PPh}_{3}$ catalyst system, with 2- lithiopyridine, which was transmetallated by $\mathrm{ZnCl}_{2}$ in situ to the corresponding organozinc reagent. Interestingly, the analogous Stille cross-coupling using 2-tributylstannyl pyridine was far less efficient and gave a low yield of the desired product.
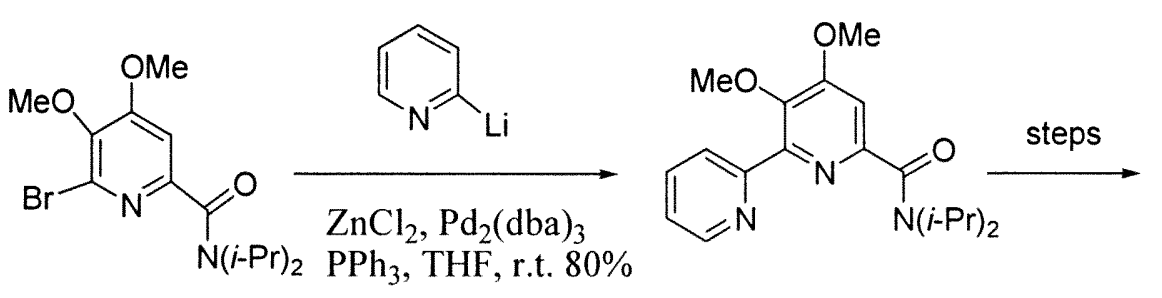<smiles>COc1cc(/C=N/O)nc(-c2ccccn2)c1OC</smiles>

Caerulomycin C

Scheme 11. Synthetic application of Negishi coupling.

\subsubsection{Negishi cross-couplings involving $\mathrm{Csp}^{2}-\mathrm{Csp}^{3}$ centers.}

Alkyl halides and related electrophiles are much less reactive toward Pd than unsaturated organic electrophiles including those containing aryl, alkenyl, alkynyl, acyl as well as allyl, benzyl, and propargyl groups. The lower reactivity of alkyl halides toward Pd has been explained in terms of the lack of a proximal $\pi$ bond. A difference in reactivity of at least a 100 -fold between alkenyl and alkyl iodides has been observed. ${ }^{87}$ Until recently, the use of alkyl electrophiles lacking proximal $\pi$ bonds had been considered very difficult, and therefore the task of Pd-catalyzed alkylation had been achieved by using 
alkylmetals. Mainly, for this reason, Pd-catalyzed alkylation of alkenyl derivatives has been accomplished via the alkyl-alkenyl coupling. However, alkyl halides are not inert towards Pd. For example, the use of highly nucleophilic Pd-complexes containing bulky trialkylphosphines, such as $\mathrm{PCyp}_{3}(\mathrm{Cyp}=$ cyclopentyl $)$ and $\mathrm{PCy}_{3}(\mathrm{Cy}=$ cyclohexyl $)$, has permitted the alkenyl-alkyl coupling between alkenylzinc derivatives and alkyl iodides, bromides, and tosylates. ${ }^{88}$ Fu et al. ${ }^{89}$ also developed the first ligandless palladium based method for Negishi cross-coupling of alkyl electrophiles: $\operatorname{Pd}(\mathrm{acac})_{2}$ (bis[acetylacetonato]Pd(II)) catalyzed reactions of functionalized alkyl halides/tosylates with organozirconium reagents (Scheme 12). In view of the attractiveness of ligandless catalyst (cost, simplicity, easy purification), this method added a significant new dimension to the development of effective processes for coupling alkyl electrophiles.

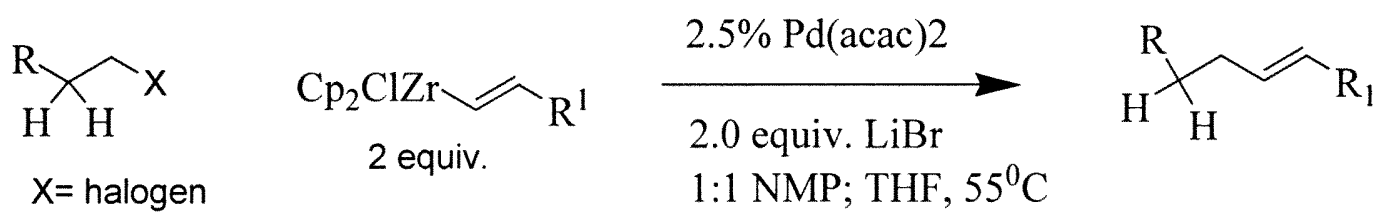

Scheme 12. Negishi cross-couplings of alkyl electrophiles under "ligandless" conditions.

Despite recent promising developments such as those mentioned above, the Pdcatalyzed alkylation of alkenyl derivatives is still achieved mostly by alkyl-alkenyl coupling protocol. In this regard, alkylzincs are generally superior to the other alkylmetals that have been examined to date, although alkylborons ${ }^{90}$ and alkylmagnesiums $\mathrm{s}^{91}$ are satisfactory in many cases. It is important to mention that in the Pd-catalyzed alkylation with alkylzincs or in general with organozincs, the precise 
composition of alkylzincs, which significantly depends on the methods of their generation, affects the course of the subsequent cross-coupling process. One important determining factor is the alkyl/Zn ratio. In a synthesis of (-)-discodermolide, it was proved to be necessary to add 3 equiv. of $t$ - $\mathrm{BuLi}$ to an alkyl iodide premixed with $\mathrm{ZnCl}_{2}$ (Scheme 13). ${ }^{92}$

A large number of natural products and related compounds have been synthesized by using the Pd-catalyzed alkenylation of alkylzinc derivatives. ${ }^{87,90-96}$

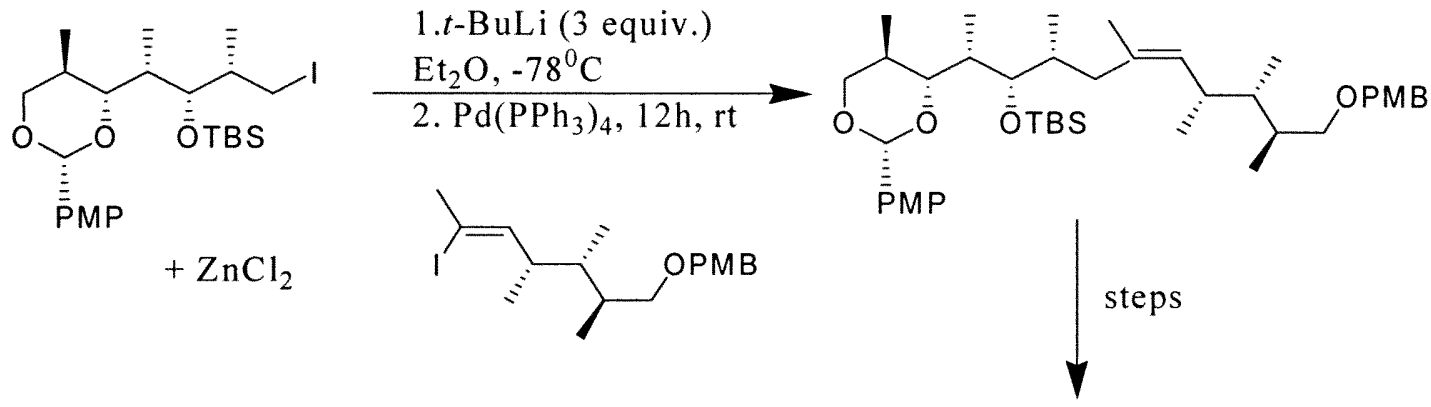

(-)-discodermolide

Scheme 13. The Pd-catalyzed alkyl-alkenyl coupling with an alkylzinc in a total synthesis of (-)-Discodermolide

Dai and $\mathrm{Fu}^{73 \mathrm{~b}}$ have also described the Negishi cross-coupling of aryl and vinyl chlorides with alkylzincs (Scheme 14). Among aryl halides, chlorides are arguable the most useful class of substrates for coupling reactions, due to their lower cost and the wider diversity of available compounds. ${ }^{97}$ The commercially available, air-stable catalyst $\operatorname{Pd}\left(\mathrm{P}(t-\mathrm{Bu})_{3}\right)_{2}$ can effect the Negishi cross-coupling of a wide range of aryl and vinyl chlorides with alkylzinc reagents in a single protocol. Besides primary alkylzinc reagents, branched alkylzincs were also used in this protocol. The Negishi couplings of branched 
alkylzincs gave desired coupling products and also isomerization products, due to the isomerization of alkyl group, mostly secondary to primary.

$$
\underset{\mathrm{R}-\mathrm{Cl}}{\operatorname{aryl} \text {; vinyl }} \underset{1.5 \text { equiv. }}{\mathrm{ClZn} \text {-alkyl }} \frac{2 \% \mathrm{Pd}\left(\mathrm{P}(t-\mathrm{Bu})_{3}\right)_{2}}{\mathrm{THF} / \mathrm{NMP}, 100^{\circ} \mathrm{C}} \mathrm{R} \text { - alkyl }
$$

Scheme 14. Negishi cross-couplings of aryl and vinyl chlorides with alkylzincs

\subsubsection{Negishi cross-couplings with dihalovinyl derivatives}

Although the development of the monosubstitution reaction of the dihalo-alkenes with aryl, ${ }^{98}$ alkenyl, ${ }^{74 a, b}$ and alkynyl metals ${ }^{74 \mathrm{e}}$ and related nucleophiles has been reasonably successful, the Pd- or Ni-catalyzed monoalkylation has not been, ${ }^{99}$ except in one isolated example published in 1987 by Minato et al.. ${ }^{76 a}$ In fact, this was the first successful regioand stereoselective monoalkylation and -arylation of 1,1-dichloro-1-alkenes by organozinc or Grignard reagents in the presence of $\mathrm{PdCl}_{2}(\mathrm{dppb})$ as a catalyst, $(\mathrm{dppb}=$ diphenylphosphine butane) which produced 1-substituted (Z)-chloro-alkenes (Scheme 15). ${ }^{76 a}$ In the only example of trans-selective monoalkylation reported in this paper, $n$ $\mathrm{BuZnCl}$ led to the desired monobutylated product, trans 2- chloro-1-phenyl-1-hexene $\mathbf{4 5}$ while the use of $n$-BuMgBr did not afford the desired product. The Pd-catalyzed second alkylation of the monobutylated intermediate with $n$-HexMgBr led to the formation of the trisubstituted alkene 46 in $77 \%$ yield (Scheme 15). Most probably, the first-stage alkylation was strongly aided by the fact that the starting material was $\beta, \beta-$ dichlorostyrene, since attempts to achieve analogous trans-selective monoalkylation of 2- 
alkyl-substituted 1,1-dichloro- or 1,1-dibromo-1-alkenes under the same conditions failed. $^{76 a}$

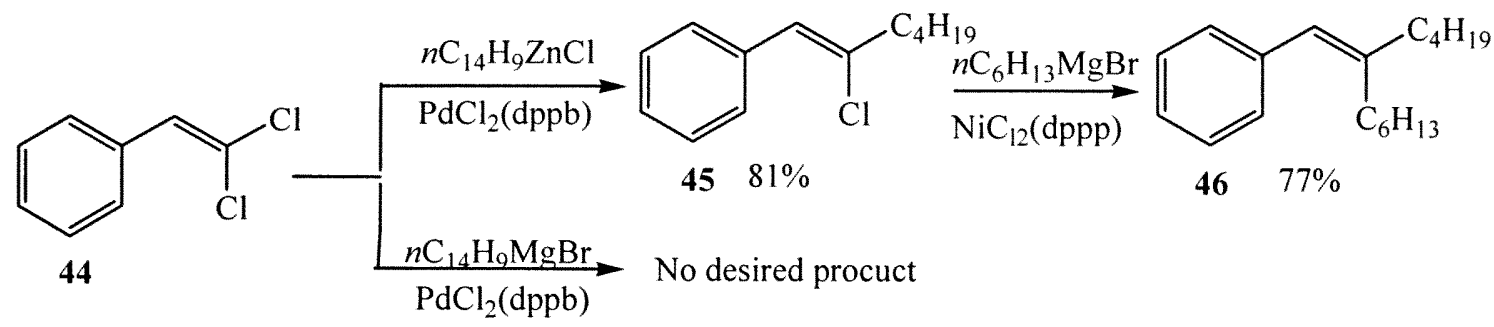<smiles>c1ccc(P(CCCCP(c2ccccc2)c2ccccc2)c2ccccc2)cc1</smiles>

Scheme 15. Pd-catalyzed double-alkylation of $\beta, \beta$-dichlorostyrene. ${ }^{76 a}$

Since the discovery of the Pd-catalyzed highly trans-selective monosubstitution of 1,1-dichloro-1-alkenes followed by the second Pd-catalyzed substitution to produce trisubstituted alkenes (Scheme 16) ${ }^{76 a}$, its development as a method for not only the selective synthesis of monosubsituted products $^{74 c, 100}$ but also for disubstitution products $^{74,76 a}$ has attracted considerable attention from synthetic chemists.<smiles>[R]C=C([X])[X]</smiles><smiles>[R2][R17](C)(C)CC</smiles><smiles>[R]C=C([R])[X]</smiles>

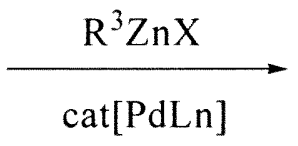<smiles>[R]C=C([R])[R]</smiles>
$\mathrm{X}=\mathrm{Cl}, \mathrm{Br}, \mathrm{I}$

Scheme 16. Pd-catalyzed trans-selective monoalkylation of 1,1-dichloro-1-alkene and Pd-catalyzed second substitution. 
In this regard, recently Tan and $\mathrm{Negishi}^{76 \mathrm{~b}}$ reported a widely applicable Pdcatalyzed trans-selective method for the monoalkylation of unactivated 1,1-dichloro-1alkenes followed by the second Pd-catalyzed substitution for the selective synthesis of the $E$ and $Z$ trisubstituted alkenes. A systematic screening of Pd catalysts, additives, and solvents was conducted, which led to an optimized set of conditions that involve $5 \mathrm{~mol} \%$ of $\left[\mathrm{PdCl}_{2}\right.$ (dpephos) $]$ (dpephos $=$ bis(o-diphenyl-phosphanylphenylether) as a catalyst/ligand and dimethylformamide (DMF) as solvent (scheme 17). In some cases, the use of one molar equivalent of $N$-methylimidazole (NMI) relative to an alkyl zinc reagent has been shown to improve the yields.

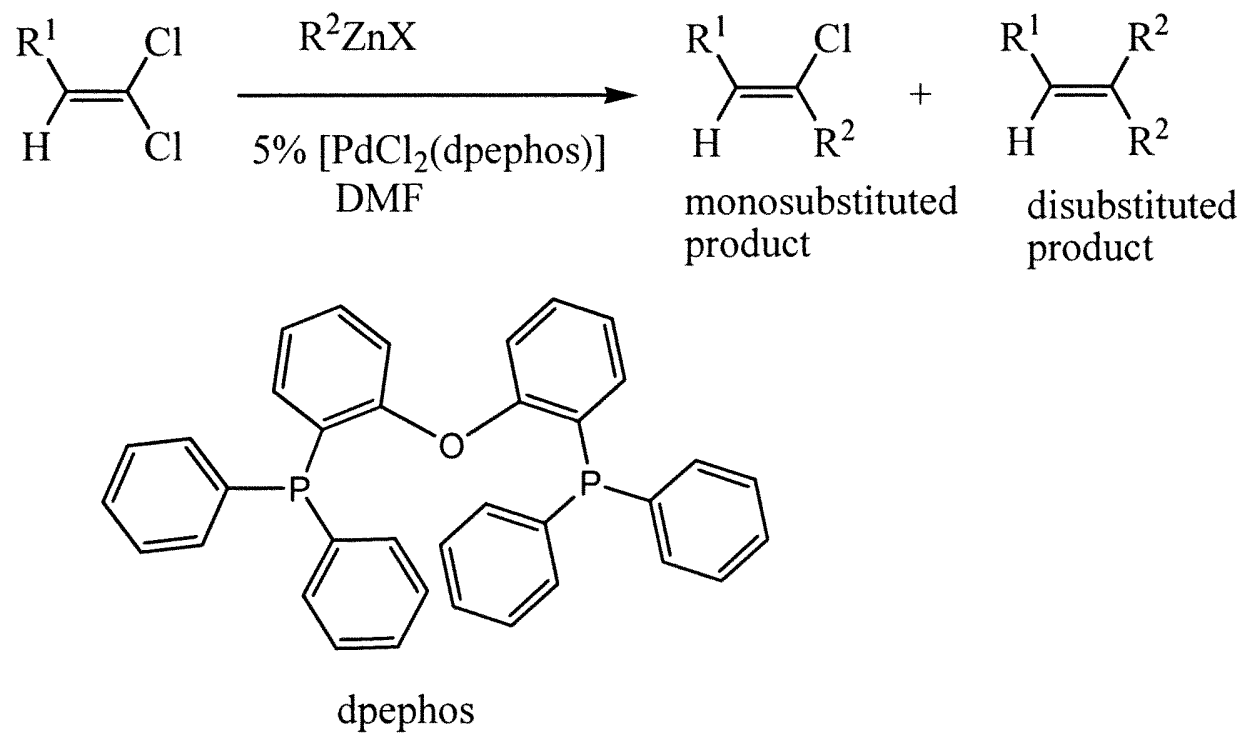

Scheme 17. Pd-catalyzed trans-selective monoalkylation of 1,1-dichloro-1-alkenes with alkylzinc reagents.

There is no example in literature on the monoalkylation of 1,1-dibromo-1-alkenes. In fact, Negishi ${ }^{76 \mathrm{~b}}$ reported that coupling of 1,1-dibromo-1-alkenes has a very high tendency to produce dialkylated products. Thus, even $\beta, \beta$-dibromostyrenes would produce only their dialkylation products. The success observed with 1,1-dichloro-1- 
alkenes but not with 1,1-dibromo-1-alkenes was explained in the mechanistic terms (Scheme 18). ${ }^{76 b}$
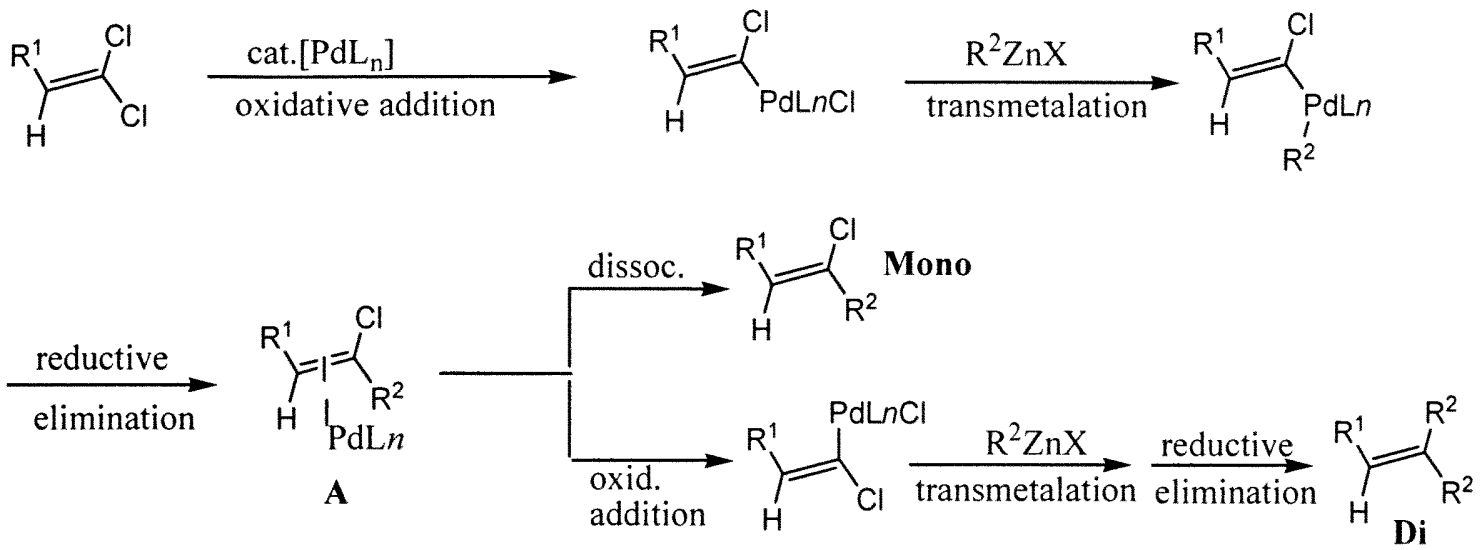

Scheme 18. Putative mechanism for the competitive formation of the mono- and dialkylation products.

Although the intricate mechanistic details remain unclear, the following characteristics are worth mentioning: the difference between dppb and dpephos ligands in the selective monoalkylation of alkyl-substituted 1,1-dichloroalkenes is noticeable, and it is clear that competitive formation of the disubstitution products is the major side reaction to be minimized. In order to minimize this side reaction, the suppressing of the second substitution through promotion of catalyst dissociation from the putative monosubstituted alkene-Pd $\pi$-complex $\mathbf{A}$ (scheme 18) is required. It is possible that the ethereal oxygen atom of dpephos may exert a chelation effect to facilitate the dissociation of alkenes. Although unwanted, the formation of the disubstitution product must undoubtedly be responsible for the high stereoselectivity ( $>98 \%$ ) attainable by Pdcatalyzed trans-selective monosubstitution through kinetic resolution in the second stage of disubstitution, in which the undesired cis-monosubstituted isomer of $\mathbf{A}$ must be 
significantly more reactive than $\mathbf{A}$ itself. In this sense, the observed formation of the disubstitution products must be a good thing in disguise to a certain extent. ${ }^{76 \mathrm{~b}}$

With the development of a widely applicable and satisfactory protocol for the transselective monoalkylation of 1,1-dichloro-1-alkenes, the second Pd-catalyzed substitution of relatively unreactive internal $Z$ chloroalkenes was also investigated. Negishi ${ }^{76 \mathrm{~b}}$ reported that the use of $\mathrm{Cy}_{3} \mathrm{P}(\mathrm{Cy}=$ cyclohexyl $)$ or $\mathrm{Cyp}_{3} \mathrm{P}(\mathrm{Cyp}=$ cyclopentyl $)$ as ligands, led to the formation of the desired alkylation products in high yields (scheme 19). Pdcomplexes with $\mathrm{Cy}_{3} \mathrm{P}$ or $\mathrm{Cyp}_{3} \mathrm{P}$ appear to be generally satisfactory catalysts for the second substitution with Grignard reagents containing alkyl, aryl, alkenyl and allyl groups. Although this protocol has not yet been applied to the synthesis of natural products, it promises to be applicable to the synthesis of natural products containing $Z$ trisubstituted alkenes, such as discodermolide ${ }^{92 b, 101}$ and hennoxazole A. ${ }^{102}$
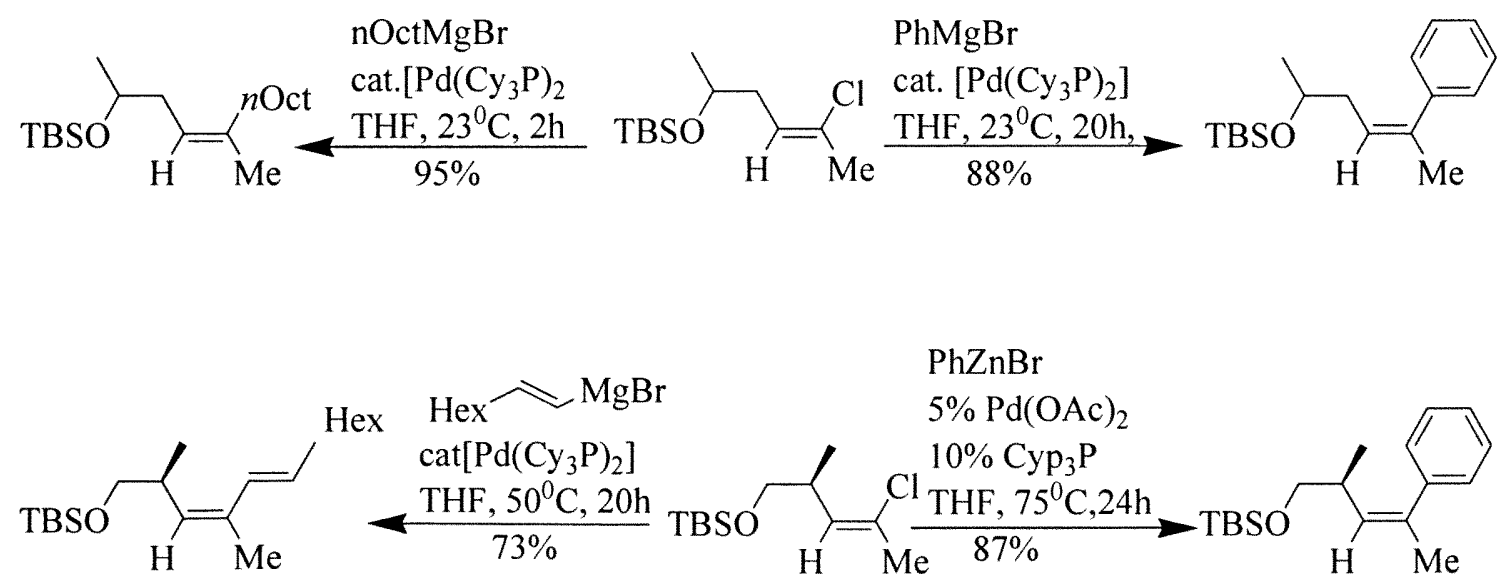

Scheme 19. Cross-coupling of internal Z-chloroalkenes with Grignard reagents in the presence of Pd catalysts containing bulky trialkylphosphines. 


\section{RESEARCH OBJECTIVES}

The purpose of this dissertation was to design and to synthesize potential inhibitors of $S$-adenosyl-L-homocysteine (AdoHcy) hydrolase, which should utilize the hydrolytic activity of the enzyme during the inhibition process. The first targets were Ladenosine $\mathbf{A}$ and its 5'-aldehyde oxime derivative $\mathbf{B}$, enantiomers of the natural substrate (Figure 10). They were designed on the basis that some unnatural L-nucleoside analogues possess more potent antiviral activity against HIV and HBV viruses than their natural Dcounterparts. We have planned to examine the possibility of whether L-adenosine and its derivatives can act as (un)likely substrates and/or inhibitors of AdoHcy hydrolase. The enzymatic studies on the interaction of L-adenosine and its 5'-oxime derivatives with AdoHcy hydrolase and computational studies of substrates specificity of the enzyme toward L-adenosine were performed in order to evaluate these targets.

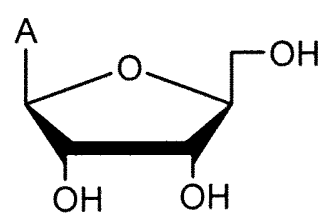

A

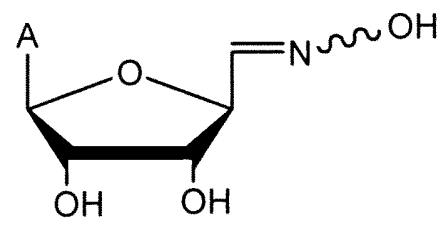

B

Figure 10. L-adenosine and its 5'-aldehyde oxime

The second targets were AdoHcy analogues of type $\mathbf{C}$ in which the sulfur and $\mathrm{C5}^{\prime}$ atoms in the $S$-adenosyl-L-homocysteine were replaced by the vinyl or the halovinyl "unit". Such compounds should be substrates for the hydrolytic activity of the enzyme. They should form "stable" complexes with the enzyme that would help to identify key binding groups at the active site of AdoHcy that interact with Hcy moiety and participate in 
subsequent elimination and hydrolytic activity steps. However, such analogs due to the lack of the leaving group (sulfur replaced by $\mathrm{sp}^{2}$ carbon) can not undergo elimination of the Hcy surrogate upon oxidation of the 3'-hydroxyl to its 3'-keto derivative. It is believed that, the individual steps can be "frozen" and the proteins at the active site of the enzyme identified. These unsaturated AdoHcy analogues were attempted to be synthesized via metathesis between 5'-deoxy-5'-methylene adenosine $\mathbf{G}$ and racemic or chiral unsaturated amino acid derivatives F (Scheme 20). Successive brominationdehydrobromination at the $\mathrm{C}^{\prime}$ '- $\mathrm{C}^{\prime}$ ' double bond of $\mathbf{C}(\mathrm{X}=\mathrm{H})$ was expected to afford AdoHcy analogues with $\mathrm{C} 5^{\prime}$ and sulfur atom replaced by the halovinyl unit.<smiles>Nc1ncnc2c1ncn2C1OC2OC1C(O)C2O</smiles>

\section{AdoHcy}

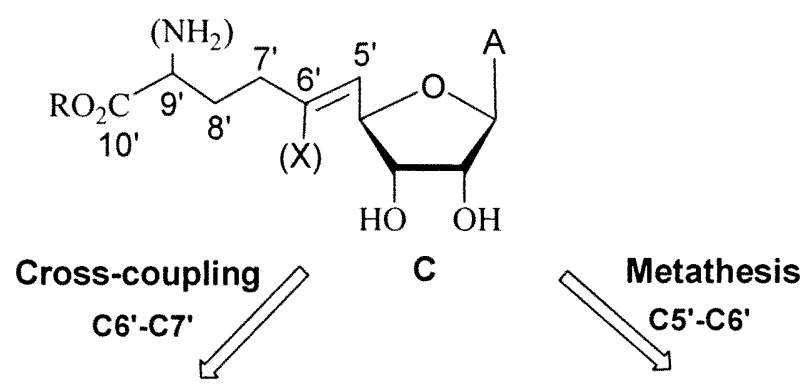

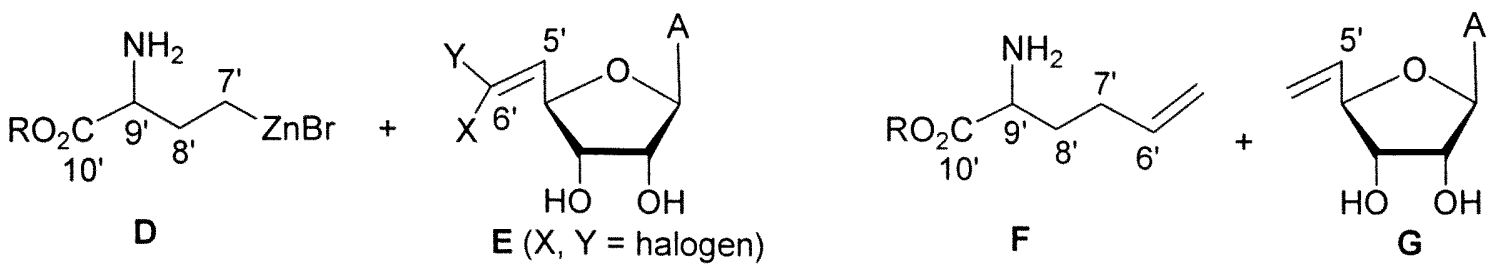

Scheme 20. Retrosynthetic analysis of AdoHcy analogues 
The analogues with halovinyl "units" were also envisioned to be synthesized directly via the Pd-catalyzed cross-coupling reactions between dihalohomovinyl nucleoside derivatives $\mathbf{E}$ and organozinc reagents $\mathbf{D}$ (Scheme 20). Since the literature reports on the Pd-catalyzed monoalkylation of dihaloalkenes $\left(\mathrm{sp}^{2}-\mathrm{sp}^{3}\right.$ coupling) were scarce, we were prompted to undertake model studies on Pd-catalyzed cross-coupling between vinyl dihalides and alkyl organometallics. We undertook effort to develop a novel Negishi monoalkylation of 1-fluoro-1-iodo, bromo or chloro- alkenes, derived from the conjugated or unconjugated aldehydes and ketones with primary, secondary and tertiary alkylzinc bromides as a novel method for the synthesis of the internal fluoroalkenes. We have also attempted cross-couplings between 1,1-dichloroalkenes and 1,1-dibromoalkenes with alkylzinc bromides. This type of coupling required developing of a novel methodology to differentiate two identical halogens in order to provide access to the multisubstituted chloro or bromo alkenes. 


\section{RESULTS AND DISCUSSION}

\subsection{Are L-adenosine and its derivatives substrates for $S$-adenosyl-L-homocysteine}

\section{hydrolase?}

\subsubsection{Synthesis of L-adenosine and L-adenosine 5'-oximes.}

The first targets of this thesis were L-adenosine $\mathbf{5 2}$ and its 5'-aldehyde oxime derivative 55. The L-adenosine 52 was prepared from L-xylose 44 utilizing the Moyround and Strazewski protocol (Scheme 21). ${ }^{103}$ In the first step of synthesis, L-xylose was acetonated in the presence of sulfuric acid to give the 1,2-O-isopropylidene- $\alpha$-Lxylofuranose $\mathbf{4 5}$. Compound $\mathbf{4 5}$ was then silylated with tert-butyldiphenylsilyl chloride at the primary 5- hydroxyl group under standard conditions to give 46 in $90 \%$ yield. The inversion of configuration at $\mathrm{C} 3$ was accomplished via an oxidation/reduction procedure. Thus, ketone 47 was obtained by treatment of 46 with $\mathrm{CrO}_{3}$ /pyridine complex in $\mathrm{CH}_{2} \mathrm{Cl}_{2}$. The subsequent reduction step was performed with $\mathrm{NaBH}_{4}$ in EtOH and led to the Lribosyl derivative 48 . Deacetonization of 48 with $\mathrm{MeOH} / \mathrm{H}_{2} \mathrm{SO}_{4}$ and $O$-methylated at $\mathrm{Cl}$ in one pot followed by $O$-benzoylation gave 1-O-Methyl-2,3,5-tri- $O$-benzoyl-Lribofuranose 49 (as a mixture of $\alpha$ and $\beta$-anomers) in $80 \%$ yield of sufficient purity to be used in the next glycosidation step. According to Vorbruggen ${ }^{104 a}$ the best leaving group for the formation of the required oxonium intermediate is acetate at $\mathrm{Cl}$ and in the $\beta$ position. Treatment of $\mathbf{4 9}$ with a mixture of glacial acetic acid, acetic anhydride and sulfuric acid at $0{ }^{\circ} \mathrm{C}$ led to the standard ribosyl donor $1-O$-acetyl-2,3,4- tri- $O$-benzoyl-Lribofuranoside $\mathbf{5 0}$ as an $\alpha / \beta$ mixture (1:3). The pure $\beta$-anomer was obtained after column chromatography. The introduction of the $\beta$-N-glycosidic bond was accomplished through the well-establish procedure reported by Vorbruggen. ${ }^{104 b, c}$ Thus, subjection of $\mathbf{5 0}$ with 6- 
$N$-benzoyladenine in the presence of TMSOTf, MFSTA in 1,2-dichloroethane gave protected L-adenosine derivative $\mathbf{5 1}$ in $86 \%$ yield. The standard deprotection of $\mathbf{5 1}$ with $\mathrm{NH}_{3} / \mathrm{MeOH}$ furnished the L-adenosine $\mathbf{5 2}$ in high yield.
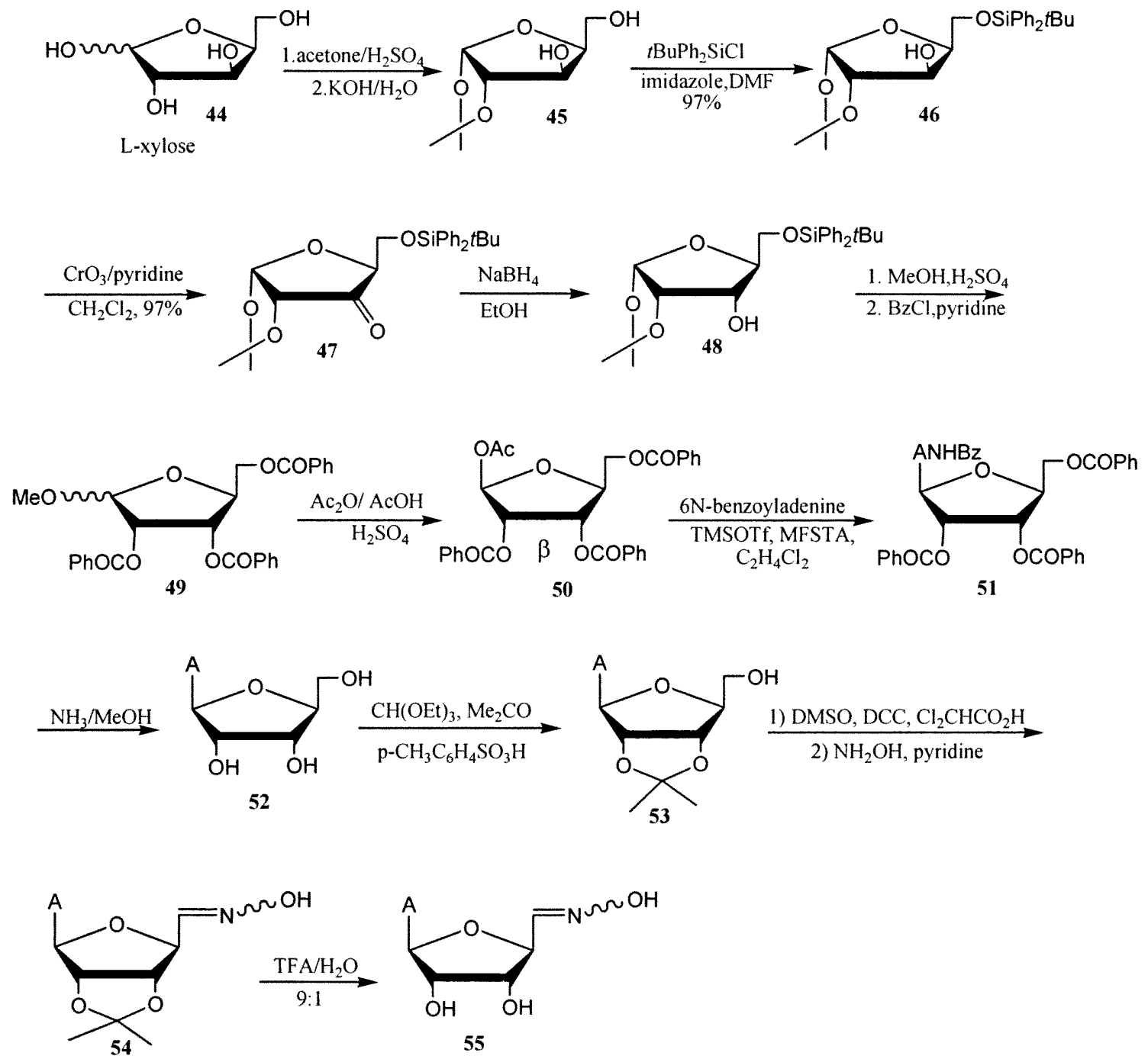

Scheme 21. Synthesis of L-adenosine and L-adenosine 5'-oximes. 
The 2',3'-O-isopropylidene-L-adenosine $\mathbf{5 3}$ was prepared by treatment of Ladenosine 52 in the presence of trietyl orthoformate in dried acetone with ptoluenesulfonic acid monohydrate. Moffat oxidation of 2',3'-O-isopropylidene-Ladenosine $\mathbf{5 3}$ gave crude 5'-aldehyde that was treated with hydroxylamine hydrochloride in pyridine to give the protected oxime $54(E / Z, \sim 6: 1 ; 80 \%)$. Acid-catalyzed removal of isopropylidene group gave $\mathbf{5 5}(E / Z, 6: 1 ; 89 \%)$. Oximes $\mathbf{5 5}$ have spectroscopic properties identical to those of their known enantiomer, adenosine 5'-carboxaldehyde oximes. ${ }^{105}$

\subsubsection{Theoretical studies of L-adenosine}

\subsubsection{Computational results with L-adenosine.}

In order to find the differences for the preferred protein:ligand binding modes, interaction strengths and binding specificity for the adenosine and L-adenosine the AutoDock simulations were perfomed. For each protein:ligand pair 128 LGA (Lamarckian Genetic Algorithm) docking runs were performed, with each run producing one possible binding mode or solution. The 128 solutions were first sorted in terms of the binding mode, i.e. the position and orientation of the ligand relative to the protein target. The solutions having rms (root mean square) deviations in ligand atomic positions of less than $0.5 \AA$ were grouped into a cluster. The total number of clusters generated measures the specificity of binding. A small number of clusters indicates that the ligand has only a few possible binding modes, and interacts with a specific site (or sites) on the target protein. On the other hand, a large number of clusters implies the existence of a wide range of binding modes and lack of specific ligand:target interactions. The second step in sorting solutions involves identification of the solution of lowest binding energy within 
each cluster and ranking the different clusters according to this energy value. The solution with the lowest energy in the top ranked (i.e. lowest-energy) cluster, as well as all solutions with energies higher by up to $5.0 \mathrm{kcal} / \mathrm{mol}$ were considered as possible binding modes for ligand and target.

\subsubsection{Docking of L-adenosine to the closed structure of AdoHcy hydrolase}

A summary of the AutoDock results is presented in Table 2. For the L-Ado, AutoDock produced 24 clusters out of 128 runs (Table 2). The first cluster consisted of 26 solutions, with the average docking energy of $-16.3 \mathrm{kcal} / \mathrm{mol}$. The positions of the first and second clusters are about $2 \AA$ away from the substrate in the 1A7A crystal structure, indicating that L-Ado does not fit into the inhibitor/substrate binding site. Comparison of the AutoDock results suggests that L-Ado should be a poor substrate of AdoHcy hydrolase compared to D-Ado. The binding of L-Ado to the protein is both weaker (higher energy) and less specific (larger number of clusters) compared to D-Ado. The binding energy difference $\Delta \mathrm{E}=-18.9-(-16.3)=-2.6 \mathrm{kcal} / \mathrm{mol}$ corresponds to a change in the binding constant by a factor of $\exp (-\Delta \mathrm{E} / \mathrm{RT})=76$ at room temperature. The microscopic reason for these effects appears to be a lack of fit between L-Ado and the inhibitor/substrate binding site. Lack of the structural fit was recently observed by

computer overlaid structures of $\mathrm{D}$ and $\mathrm{L}$ enantiomers of $6^{\prime}(E)$ (bromohomovinyl)adenosine (e.g., $\mathrm{C}: \mathrm{X}=\mathrm{Br}, \mathrm{Y}=\mathrm{H}){ }^{106}$ 
Table 2. Summary for autodock results for D-Ado and L-Ado docking to the closed form of AdoHcy hydrolase

\begin{tabular}{|c|c|c|c|}
\hline & $\begin{array}{c}\text { Total number of } \\
\text { clusters }^{\mathrm{a}}\end{array}$ & $\begin{array}{c}\text { Av. Energy of top } \\
\text { cluster }^{\mathrm{b}}(\mathrm{kcal} / \mathrm{mol})\end{array}$ & $\begin{array}{c}\text { Number of solutions } \\
\text { in } \\
\text { top of cluster }\end{array}$ \\
\hline D-Ado & 16 & $-18.9+/-0.3$ & 21 \\
\hline L-Ado & 24 & $-16.3+/-0.3$ & 26 \\
\hline
\end{tabular}

${ }^{a}$ Clustering of a total of 128 runs. ${ }^{b}$ Average binding energy of the first cluster for L-Ado and second cluster for D-Ado. ${ }^{c}$ Standard deviation over solutions within cluster.

The docking results are approximate. The scoring is based on an empirical energy function, solvation effects treated with a highly simplified model, and only ligand flexibility taken into account, with the protein structure kept fixed. ${ }^{107}$ The binding energy difference calculated here, $-2.6 \mathrm{kcal} / \mathrm{mol}$, is only slightly greater in magnitude than the estimated standard error of the method, $2 \mathrm{kcal} / \mathrm{mol}$. Thus, the AutoDock results should be only considered as qualitative. The calculated binding energy results are in qualitative agreement with the observed inhibitory effects. Additionally, the simulations suggest that L-Ado has a lower specificity and worse fit into the known active site than D-Ado.

\subsubsection{Interaction of AdoHcy hydrolase with L-Adenosine}

L-Adenosine $\mathbf{5 2}$ and its 5 '-oxime derivatives $\mathbf{5 5}$ were evaluated for their ability to inhibit the activity of recombinant human placental AdoHcy hydrolase by incubating the enzyme with the compounds at $200 \mu \mathrm{M}$ for $20 \mathrm{~min}$ at $37^{\circ} \mathrm{C}$. The AdoHcy hydrolase activity was determined by assaying the enzyme's ability to catalyze the conversion of Ado and Hcy to AdoHcy. Under these conditions, both $\mathbf{5 2}$ and $\mathbf{5 5}$ were inactive as inhibitors of the AdoHcy hydrolase. In contrast, adenosine-5'-carboxaldehyde oximes 
under these conditions produce $72 \%$ inhibition of the enzyme. Adenosine-5'carboxaldehyde oxime is known to be a potent inhibitor of AdoHcy hydrolase with $K_{\mathrm{i}}$ and $k_{\text {inact }}$ values of $0.67 \mu \mathrm{M}$ and $0.16 \min ^{1}$, respectively ${ }^{105}$ and is a substrate for the enzyme hydrolytic activity. ${ }^{108}$

Our findings ${ }^{106 \mathrm{a}}$ are in agreement with a recent report $^{106 \mathrm{~b}}$ where the (halohomovinyl) and acetylenic derivatives of L-adenosine were found to be much weaker inhibitors than the corresponding analogues derived from adenosine. ${ }^{35}$ In conclusion, docking calculations showed that binding of L-Ado is not as specific as that of D-Ado for human AdoHcy hydrolase and that the binding energy of the DAdo/enzyme complex is lower than that of the L-Ado/enzyme complex. These results might explain why L-Ado and its analogues were found to be inactive as inhibitors of AdoHcy hydrolase, and therefore not good candidates for drug design targeting AdoHcy hydrolase and/or transmethylation enzymes.

\subsection{Design and synthesis of S-adenosylhomocysteine analogues with the sulfur and $\mathrm{C}^{\prime}$ ' atoms replaced by the vinyl unit.}

The second targets of this thesis were S-adenosyl-L-homocysteine analogues of type $\mathbf{A}$ and $\mathbf{B}$ with the sulfur and $\mathrm{C}^{2}$ ' atoms replaced by the vinyl or homovinyl unit (Scheme 22). Retrosynthetic analyses of compound $\mathbf{A}$ indicate that the easiest approach would be to start synthesis from the parental nucleoside and the suitable constructed amino acid units. First approach was envisioned to be metathesis via construction of a new C5'-C6' double bond using two terminal alkenes in the presence of Grubbs catalyst. 
The second approach employed Negishi coupling to construct a new C6'-C7' single bond between dihalonucleoside derivative with the corresponding organozinc reagent.<smiles>Nc1ncnc2c1ncn2[C@@H]1O[C@H](CSCC[C@H](N)C(=O)O)[C@@H](O)[C@H]1O</smiles>

\section{Metathesis}<smiles></smiles>
$\mathbf{A ~ X}=\mathbf{H}$
B X $=$ halogen

(C5'-C6'double bond)

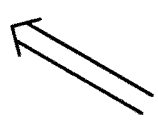

Negishi cross-coupling (C6'-C7'single bond)

Scheme 22. Retrospective analysis for the unsaturated S-adenosyl-L-homocysteine analogues.

\subsubsection{Metathesis approach between the 5'-deoxy-5'-methyleneadenosine and the racemic homoallylglycine precursors.}

In order to explore the metathesis approach the protected 5'-deoxy-5'methyleneadenosine derivatives (e.g. 60 or 61) and the 6-carbon amino acid, e.g. homoallylglycine 65 or 66 bearing a terminal double bond were prepared. Synthesis of the protected 5'-deoxy-2',3'-O-isopropylidene-5'methyleneadenosine started with adenosine 56 which was dissolved in acetone and treated with $p$-toluenesulfonic acid and 
ethyl orthoformate. Crystallization of the crude product from $\mathrm{MeOH}$ gave 2',3'-Oisopropylidene adenosine $\mathbf{5 7}$ in $97 \%$ yield (Scheme 21). Moffat oxidation of the 5 '-OH group in $\mathbf{5 7}$ with dicyclocarbodiimide (DCC) in DMSO in the presence of dichloroacetic acid at ambient temperature afforded crude 5'-aldehyde which was in situ treated with (toluenesulfonylmethylene)triphenylphosporane $\mathrm{e}^{35}$ to produce 9-[5,6-dideoxy-2,3-Oisopropylidene-6-( $p$-toluenesulfonyl)- $\beta$-D-ribo-hex-5(E)-enofuranosyl]adenine $\mathbf{5 8}$ in $80 \%$ yield after purification on silica gel column. ${ }^{1} \mathrm{H}$ NMR spectrum confirmed the structure and the trans configuration was assigned on the basis of the magnitude of the coupling constant $\left(J_{6^{\prime}-5}=15.1 \mathrm{~Hz}\right)$. Reflux of $\mathbf{5 8}$ in toluene with tributyltin hydride in the presence of AIBN effected stanylo-detosylation via a radical addition-elimination reaction. The 9[6-(tributylstannyl)-5,6-dideoxy-2,3-O-isopropylidene- $\beta$-D-ribo-hex-5-enofuranosyl] adenine 59 was obtained in $71 \%$ yield as a separable mixture of $E / Z$ isomers $(\sim 5: 1)$. The stereochemical composition of the mixture was established based on the coupling constant analysis in ${ }^{1} \mathrm{H}$ NMR spectrum $\left[\mathbf{5 9}(E)\left(J_{6^{\prime}-5^{\prime}}=19.1 \mathrm{~Hz}\right), \mathbf{5 9}(Z)\left(J_{5^{\prime}-6^{\prime}}=12.8 \mathrm{~Hz}\right)\right]$. Treatment of $59(E / Z)$ with $\mathrm{NH}_{4} \mathrm{~F}$ in $\mathrm{MeOH}$ at reflux for $48 \mathrm{~h}$ produced a more polar 9[5,6-dideoxy-2,3- $O$-isopropylidene- $\beta$-D-ribo-hex-5-enofuranosyl]adenine $\mathbf{6 0}$ in $90 \%$ yield after purification on silica gel column. Splitting pattern for protons of the terminal alkene group at $\delta 5.13\left[\left(\mathrm{~d}, J_{6^{\prime}-5^{\prime}}=10.4 \mathrm{~Hz}\left(\right.\right.\right.$ cis $\left.\left.^{\prime}\right), J_{6^{\prime} \cdot 6^{\prime}}{ }^{\prime}=1.2 \mathrm{~Hz}\right)$ and $5.25\left[J_{6^{\prime}-{ }^{\prime}},=17.2 \mathrm{~Hz}\right.$ (trans) H6"] were confirmed on ${ }^{1} \mathrm{H}$ NMR spectrum. In order to protect the amino group from the adenine ring, compound $\mathbf{6 0}$ was dissolved in dried pyridine and reacted with benzoyl chloride to provide 61a in $95 \%$ yield. Treatment of $\mathbf{6 0}$ with excess of benzoyl chloride afforded $\mathbf{6 1 b}$ in $98 \%$ yield. 


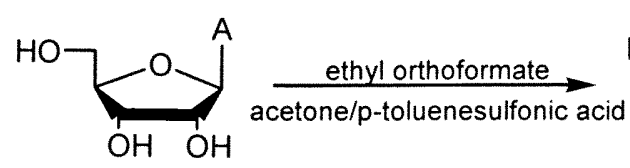

56

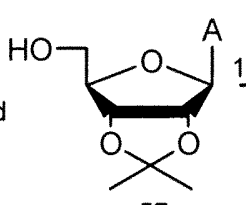

57

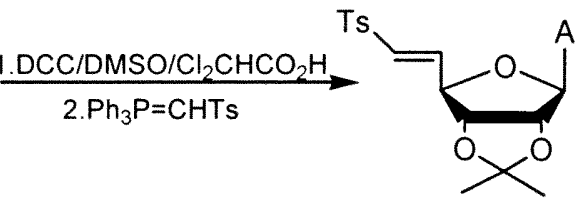

$\mathrm{Bu}_{3} \mathrm{SnH}$

AIBN

toluene<smiles>BC1O[C@@H](C=C)OC(C)(C)O1</smiles>

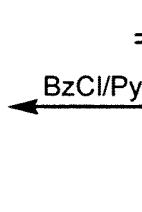

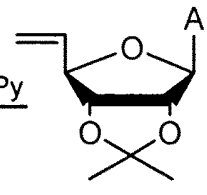

60

$\mathrm{NH}_{4} \mathrm{~F} / \mathrm{MeOH}$

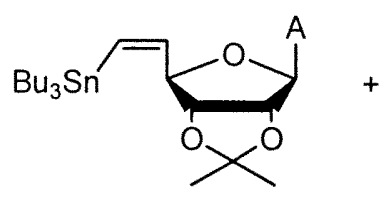

$59 Z$

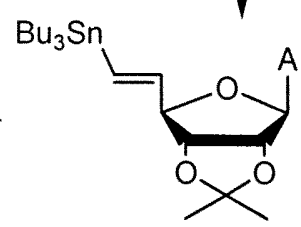

$59 E$
a. $B=A^{N H B z}$
b. $B=A^{B z 2}$

Scheme 23. Synthesis of the protected 5'-deoxy-2',3'-O-isopropylidene-5'-methylene adenosine

The synthesis of the unsaturated amino acid precursors (homoallylglycine) for the metathesis approach is depicted in scheme 24 . Thus, the unsaturated $\alpha$-amino acid 63 was obtained in $72 \%$ in phase-transfer catalyzed $\mathrm{S}_{\mathrm{N}} 2$ reaction ${ }^{109}$ between commercially available $N$-(diphenylmethylene)glycine ethyl ester 62 and 4-bromo-1-butene. ${ }^{1} \mathrm{H}$ NMR spectrum of 63 confirmed the presence of the characteristic splitting for a terminal alkene. Acid deprotection ${ }^{110}$ of $\mathbf{6 3}$ afforded the corresponding racemic mixture of amino acid 64 in $96 \%$ yield with the appropriate number of carbons suitable for the metathesis approach. It is worthy to note that there is an extra carbon in chain as compared with homocysteine, because one of the carbon will be lost during metathesis with 5'-deoxy-5'methyleneadenosines 60 or 61 . Benzoylation of the amino group in 64 with $\mathrm{BzCl}$ in pyridine gave the $\mathrm{N}$-benzoyl aminoacid $\mathbf{6 5}$ in $89 \%$ yield as a white solid after purification on silica gel column. ${ }^{1} \mathrm{H}$ NMR spectrum of $\mathbf{6 5}$ showed peaks from the aromatic protons at 
$\delta 7.38-7.52(\mathrm{~m}, 5 \mathrm{H}, \mathrm{Ar})$. Compound $\mathbf{6 5}$ had also UV for better control of the subsequent metathesis reaction. Treatment of $\mathbf{6 4}$ with $(\mathrm{tBuO})_{2} \mathrm{CO}$ and $\mathrm{NaHCO}_{3}$ in dioxane provided $N$-Boc aminoacid derivative 66.

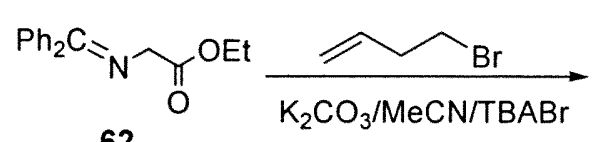

62

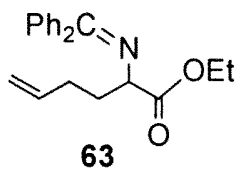

63<smiles>C=CCCC(N)C(=O)OCC</smiles>

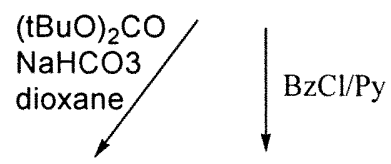<smiles>C=CCCC(N)C(=O)OCC</smiles>

Scheme 24. Synthesis of the amino acid precursors for metathesis approach.

Attempted cross-metathesis ${ }^{45,46,47 b, 70}$ between 5'-deoxy-2',3'-O-isopropylidene5 '-methylene adenosine 60 with $N$-benzoyl 65 or $N$-Boc 66 protected amino acids bearing the terminal double bond in the presence of $1^{\text {st }}$ and $2^{\text {nd }}$ (2-imidazolinylidene-Ru) generation Grubbs catalysts ${ }^{46,47 b}$ failed to give desired products $67 \mathbf{a}$ or $68 \mathbf{a}$ (Scheme 25). Also, metathesis of the 6-N-benzoyl adenosine substrate $61 \mathrm{a}$ with 65 or 66 in the presence of the same catalysts did not afford the desired products. However, treatment of 61a with 65 in the presence of Hoveyda-Grubb's catalyst ${ }^{111 a, b}$ led to the formation of metathesis product $67 \mathrm{~b}(51 \%)$ in addition to dimer $73(11 \%)$ as a less polar compound. Self-metathesis of adenosine substrate 61a was not observed. Metathesis of the $6-\mathrm{N}, \mathrm{N}-$ dibenzoyl 61b with 65 gave 67c in $60 \%$ yield in addition to dimer 73 (18\%). Interestingly, metathesis of the 5'-deoxy-5'-methylene adenosine 60 having 6-amino 
group unprotected with $\mathbf{6 5}$ or $\mathbf{6 6}$ even in the presence of Hoveyda-Grubb's catalyst did not yield the corresponding cross-metathesis products $67 \mathbf{a}$ or $68 \mathrm{a}$. This means that the protection of 6-amino group of adenine plays an important role in cross-metathesis reaction and more than likely is necessary.

The cross-metathesis reaction $\left(\mathrm{CH}_{2} \mathrm{Cl}_{2}\right.$, at $\left.65^{\circ} \mathrm{C}\right)$ between protected 5'-deoxy-5'methylene adenosine $61 \mathrm{a}$ or $61 \mathrm{~b}$ with racemic $N$-Boc protected aminoacid 66 in the presence of Hoveyda-Grubbs catalyst gave the desired products $68 \mathrm{~b}(61 \%)$ and $68 \mathrm{c}^{111 \mathrm{c}}$ (76\%) respectively, (Scheme 25). The self-metathesis of nucleosides substrates or amino acid byproducts were not isolated from the reaction mixtures. In agreement with literature reports, ${ }^{112}$ the cross-metathesis products 67 and 68 were found to be predominantly the trans-isomers. Column chromatography on silica gel afforded products 67 and 68 as pure $5^{\prime} E$ isomers of the $1: 1$ mixture of $9^{\prime} R / S$ diastereomers. ${ }^{1} \mathrm{H}$ NMR and mass spectrometry confirmed the structure of 67 and 68. The $E$ stereochemistry for 67 and 68 was established from ${ }^{1} \mathrm{H}$ NMR spectra based on the magnitude of $J_{\mathrm{H} 5^{\prime}-\mathrm{H} 6^{\prime}}$. For example, the $5^{\prime}$ proton in 68c appears at $\delta 5.58\left(\mathrm{dd}, J_{\mathrm{H} 5^{\prime}-\mathrm{H} 4^{\prime}}=7.3 \mathrm{~Hz}\right.$ and $\left.J_{\mathrm{H} 5^{\prime}-\mathrm{H} 6^{\prime}}=15.2 \mathrm{~Hz}\right)$ while the $6^{\prime}$ proton resonates at $\delta 5.73\left(\mathrm{dt}, J_{\mathrm{H} 6^{\prime}-\mathrm{H} 7^{\prime} / 7^{\prime \prime}}=6.5 \mathrm{~Hz}\right.$ and $\left.J_{\mathrm{H} 5^{\prime}-\mathrm{H} 6^{\prime}}=15.2 \mathrm{~Hz}\right)$.

The next step in the synthesis of desired AdoHcy analogues was deprotection of products 67 and 68 . Thus, treatment of $68 \mathrm{c}$ (or $68 \mathrm{~b}$ ) with 1:1 mixture of the saturated (at $0{ }^{0} \mathrm{C}$ ) methanolic ammonia solution and methanol for $48 \mathrm{~h}$ at $\sim 0{ }^{0} \mathrm{C}$ removed the $6-N$ benzoyl group(s) and afforded a partially separable mixture of methyl 69 and ethyl 70 esters $(\sim 3: 2, \sim 92 \%$ total yield). The use of diluted methanolic ammonia solution was important since saturated solution of $\mathrm{NH}_{3} / \mathrm{MeOH}$ led to the formation of the amidation byproducts in substantial yield (up to $40 \%$ ). 


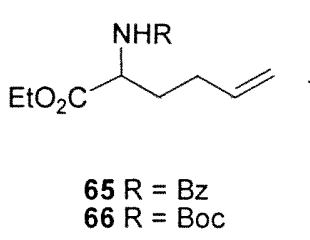

$66 R=B O C$

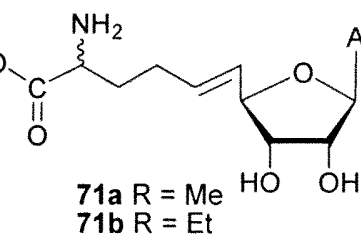
$\mathrm{NaOH} / \mathrm{H}_{2} \mathrm{O}$<smiles>[Y][C@H](C)OOO</smiles>

Cmpds 67-68: a $B=A$

b $B=A^{N H B z}$

c $B=A^{B z 2}$
TFA/ $\mathrm{H}_{2} \mathrm{O}$

$60 \mathrm{~B}=\mathrm{A}$

$61 \mathrm{~b} B=A^{B z 2}$ 61a $B=A^{N H B z}$
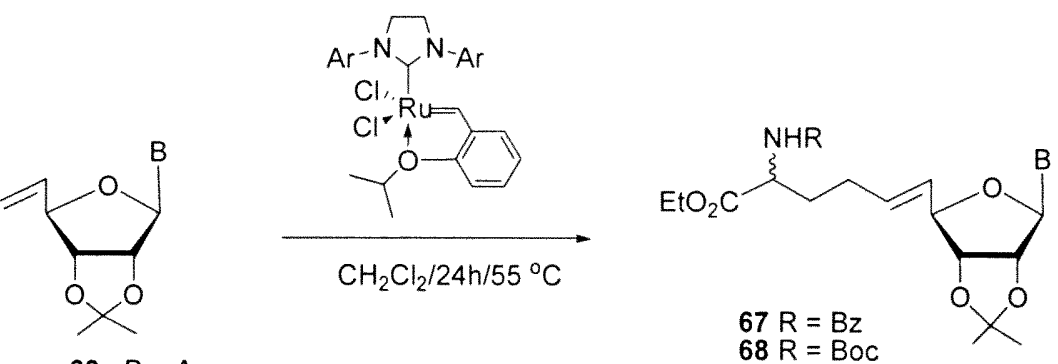

$68 R=B O C$

$\mathrm{NH}_{3} / \mathrm{MeOH} \mid \mathrm{R}=\mathrm{BOC}$<smiles>[Y]CCOC(=O)C(CCC=C(C)C)N[R]</smiles>

73

69

70

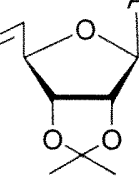<smiles>CC(C)NC(=O)NC(C)CCC=CC1OC2COC1C1OCOC21</smiles>

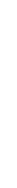




\subsubsection{Metathesis approach between the 5'-deoxy-5'-methylene adenosine and the chiral homoallylglycine precursors.}

In order to synthesize AdoHcy analogue having the L-configuration for the amino group which corresponds to the natural aminoacids, we first attempted separation of $9^{\prime} R / S$ diastereomers in products 67 and 68. Unfortunately, separation of $9^{\prime} R / S$ diastereomers in 67 or $\mathbf{6 8}$ was unsuccessful. Then we turned our attention to the synthesis of AdoHcy analogue with 9'S configuration employing a chiral amino acid precursor, e.g., (S)-homoallylglycine. Given that the methods available for the preparation of enantiomerically pure unnatural aminoacids usually require multistep synthesis, ${ }^{113}$ we chose the enantioselective hydrolysis of racemic 66 as a way to provide chiral $(S)$ homoallylglycine.

Treatment of 66 with $\alpha$-chymotrypsin in phosphate buffer $^{114}(0.1 \mathrm{M}, \mathrm{pH} 8)$ produced the unreacted $(R)$-ester $66(\sim 50 \%)$ and $(S)$-acid $74(\sim 50 \%)$ (Scheme 26$)$. In order to establish the enantiomeric purity of $\mathbf{6 6}$ as $R$ enantiomer, the Mosher test was applied. Optically active $\alpha$-methoxy- $\alpha$-(trifluoromethyl)phenyl acetic acid (MTPA acid), known as the Mosher reagent, was originally developed in $1969^{115}$ for use in determination of the enantiomeric purity of chiral alcohols and amines by NMR spectroscopy. The use of of this reagent was subsequently expanded to chromatographic resolution of chiral alcohols ${ }^{116}$ and assigning the absolute configuration of its chiral esters based on the empirical correlation between their NMR chemical shift and the absolute stereochemistry of the alcohol. ${ }^{117}$ In our case, treatment of ester 66- $R$ with TFA/ $\mathrm{H}_{2} \mathrm{O}$ followed by acylation with (R)-2-methoxy-2-(trifluoromethyl)phenyl-2-phenylacetyl chloride ${ }^{118}\left[(R)\right.$-MPTA-Cl] gave $76 R / S$. Analysis of the ${ }^{19} \mathrm{~F}$ NMR spectra $[\delta-69.55(\mathrm{~s}$, 
$0.98 \mathrm{~F})$ and $-69.8(\mathrm{~s}, 0.02 \mathrm{~F})]$ established the stereochemistry for 66 as $R$ in agreement with Mosher' correlations. The acid 74-S was next converted into the methyl ester 75- $S$ in reaction with diazomethane in ethanol (Scheme 26). It is worthy to note that the metathesis of the "free" carboxylic acid precursor 74-S with $61 \mathrm{a}$ or $61 \mathrm{~b}$ in the presence of Hoveyda-Grubbs catalyst did not yield the desired product.
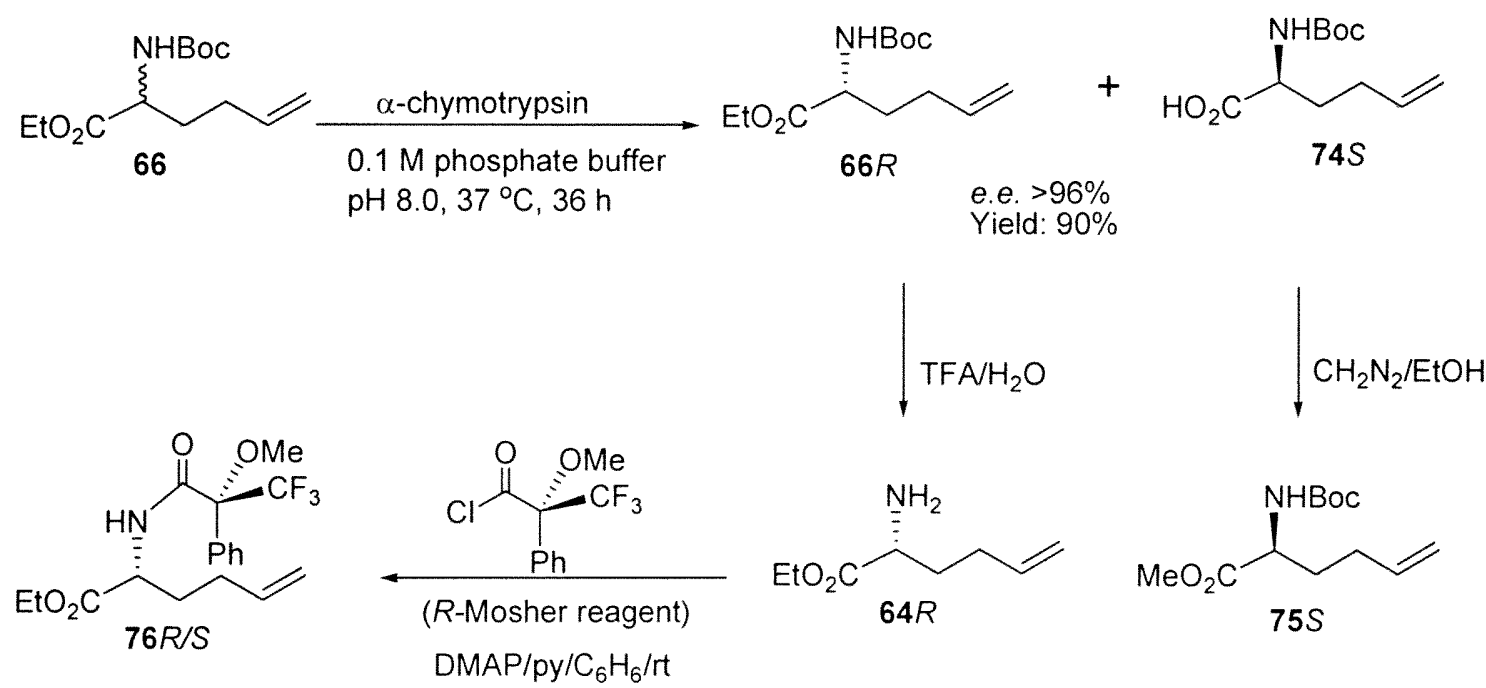

Scheme 26. Enantioselective hydrolysis of alkenyl- $\alpha$-amino acid ester.

Once the chiral amino acid precursor 75-S was synthesized, we attempted the cross-metathesis reaction between $\mathbf{6 1 b}$ and $75-S$ which afforded $77-S$ in $77 \%$ yield (Scheme 27). Standard deprotection of 77-S with diluted $\mathrm{NH}_{3} / \mathrm{MeOH}$ gave $69-\mathrm{S}$ in $91 \%$ yield. Acid deprotection with TFA/ $\mathrm{H}_{2} \mathrm{O}$ yielded methyl ester $71 \mathrm{a}-S(90 \%)$ as a single $E$ isomer after purification on RP-HPLC. Alterantively, metathesis of $\mathbf{6 1} \mathbf{b}$ with $\mathbf{6 6 -} R$ gave ethyl ester derivative $68 \mathrm{c}-R$. Contrary to the products $67-72$ obtained from racemic homoallylglycine, the ${ }^{13} \mathrm{C}$ NMR spectra for the products obtained from $(S)$ - and $(R)$ - 
homoallylglycine substrates showed a single set of peaks. 'H NMR spectrum also showed some spectral differences especially for $\mathrm{H} 2$ and $\mathrm{H} 8$ from the adenine base.

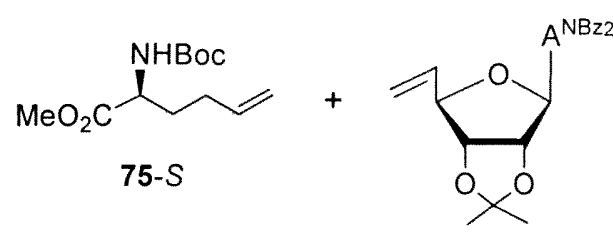

61b

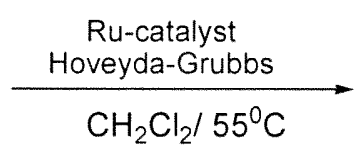

TFA/ $\mathrm{H}_{2} \mathrm{O}$<smiles>[Y]C1OC(/C=C/CC[C@@H](N)C(=O)OC)C(O)C1O</smiles>

$71 a-S$<smiles>[Y16][C@@H]1OC(/C=C/CC[C@@H](N)C(=O)OC)[C@H]2OC(C)(C)O[C@H]12</smiles>

$77-5$

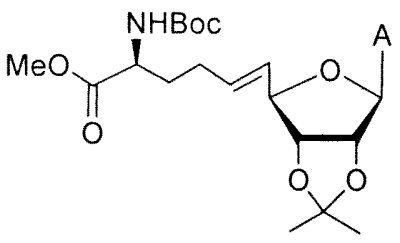

$69-5$

Scheme 27. Cross-metathesis of adenosine precursor with $S$-amino acid derivative.

\subsubsection{Synthesis of the halovinyl $S$-AdoHcy analogue.}

Taking into consideration that AdoHcy hydrolase is able to add water across to the isolated 5',6'-double bond of a 6'-halo(vinyl)homoAdo derivative, ${ }^{35,36}$ we have also attempted the synthesis of bromovinyl analogue of type B (scheme 22). This synthesis was executed using the bromination-dehydrobromination strategy (Scheme 28). Thus, treatment of $68 \mathbf{c}$ with pyridinium tribromide ${ }^{119}$ in dioxane gave the $5^{\prime}, 6^{\prime}$-dibromo diastereomers $\mathbf{7 8}$ in a very high yield. ${ }^{1} \mathrm{H}$ NMR and LC-MS spectra confirmed the structure of 78. In fact, ${ }^{1} \mathrm{H}$ NMR spectrum showed no presence of the olefinic protons and the LC-MS spectrum showed the characteristic peaks pattern $\left(\mathrm{M}^{+}+2\right.$ and $\left.\mathrm{M}^{+}+4\right)$ due to the presence of two bromine atoms. Compound $\mathbf{7 8}$ underwent dehydrobromination 
with 1,8-diazobicyclo[5.4.0] undec-7-ene (DBU) in THF yielding $\mathbf{7 9 b}$ as a single isomer. Also one of the 6-N-benzoyl protective group was partially cleaved and formation of 79a was observed. Standard deprotection of $79 \mathbf{a} / 79 \mathbf{b}$ mixture with diluted $\mathrm{NH}_{3} / \mathrm{MeOH}$ gave 80 as an inseparable mixture of methyl and ethyl esters. Treatment of $\mathbf{8 0}$ with TFA/ $\mathrm{H}_{2} \mathrm{O}$ removed both Boc and isopropylidene protection group affording 81. Saponification of 81 with solution of $\mathrm{NaOH}$ followed by RP-HPLC purification gave 82 as a single $E$ isomer in 54\% overall yield (Scheme 28).
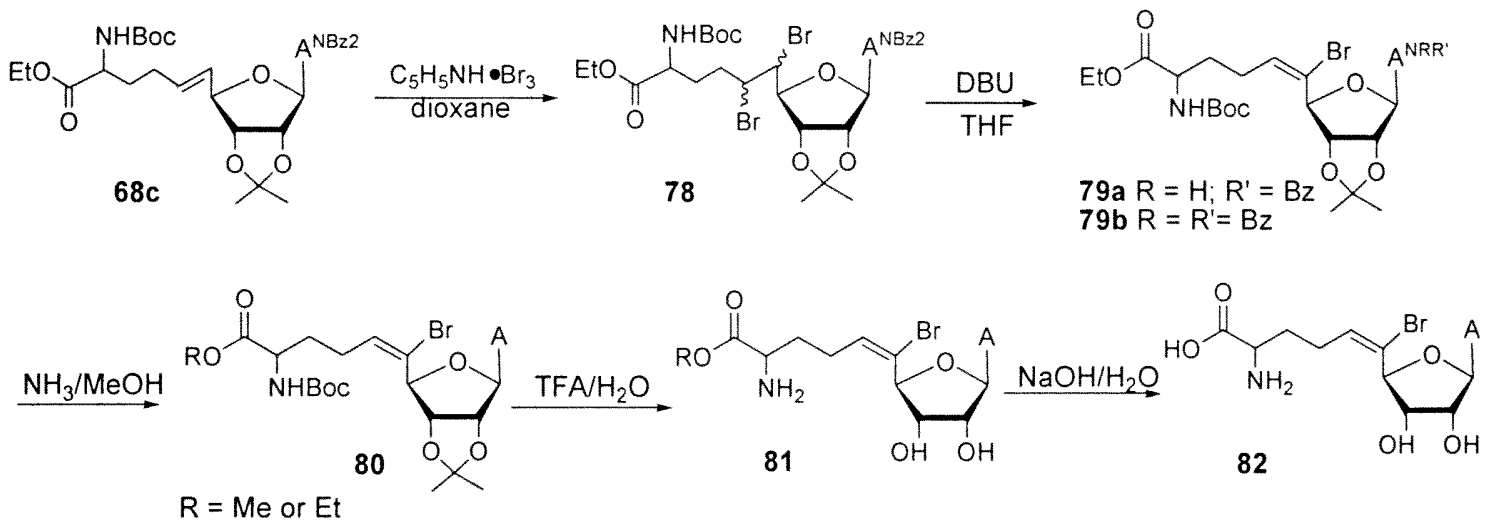

Scheme 28. Synthesis of the halovinyl S-AdoHcy analogue.

The regioselectivity of the $\mathrm{HBr}$ elimination and therefore position of the bromine at $5^{\prime}$ (versus $6^{\prime}$ ) in $\mathbf{7 9 - 8 2}$ was assigned based on the COSY experiment. The COSY experiment showed a strong cross-peak correlation between protons $\mathrm{H} 6$ ' $-\mathrm{H} 7$ ' but did not show any cross-peak between protons $\mathrm{H}^{\prime}$ '-H5'. Also 'HNMR spectrum supported this assignment. In fact, 'H NMR spectrum showed the presence of the H6' as a triplet at $\delta$ $6.40\left(J_{6^{\prime}-7^{\prime} / 7^{\prime \prime}}=7.6 \mathrm{~Hz}\right)$, rather then the expected doublet with $J_{5^{\prime}-4^{\prime}}$ for H5' in the case of 6'bromo regioisomer. 
The $E$ configuration of products $\mathbf{7 9 - 8 2}$ is expected from a specific anti-addition in the pyridinium tribromide bromination of the $E$ alkene $68 \mathrm{c}$ which is followed by an E2 (anti elimination) process of $\mathrm{HBr}$ from 78. This was also supported by the NOESY analysis of 82 in which the cross-peak between $\mathrm{H} 4^{\prime}$ and $\mathrm{H}^{\prime} / 7^{\prime \prime}$ was observed while no cross-peak between $\mathrm{H}^{\prime}$ ' and $\mathrm{H} 6$ ' was detected.

\subsection{Negishi cross-coupling approach}

\subsubsection{Coupling with 1-fluoro-1-haloalkenes}

Since the elimination of $\mathrm{HBr}$ gave 5'-bromovinyl analogue $\mathbf{8 2}$ instead of the more desired 6'-bromo analogue, we turned our attention to the coupling approach. On the basis of retrosynthetic analysis, the synthesis of analogue type $\mathbf{A}$ or $\mathbf{B}$ (see scheme 22) can be accomplished using Pd-catalyzed cross-coupling reaction between $s p^{2}$ hybridized carbon of dihalohomovinyl precursor of adenosine and $s p^{3}$ hybridized carbon of the corresponding organozinc reagent, Negishi coupling, to form a new $\mathrm{C}^{\prime}-\mathrm{C} 7$ ' single bond as a key step. Since literature reports on the Pd-catalyzed monoalkylation of dihaloalkenes $\left(\mathrm{Csp}^{2}-\mathrm{Csp}^{3}\right.$ coupling) were $\mathrm{scarce}^{76,99}$, we were prompted to undertake model studies on Pd-catalyzed cross-coupling between vinyl dihalides and alkyl organometallics.

Taking into account that the fluoride is unreactive ${ }^{71 a}$ towards couplings, we first accomplished Pd-catalyzed monoalkylation between a series of 1-fluoro-1-haloalkenes 86-88, derived from the conjugated or unconjugated aldehydes and ketones with alkyl zinc-bromides reagents. The corresponding 1-fluoro-1-haloalkenes were synthesized using McCarthy's procedure. ${ }^{120}$ In the first step aldehydes 83a-c and ketone 83d 
underwent condensation with sulfonyl-stabilized fluorophosphonates to give (fluoro)vinyl sulfones $\mathbf{8 4}$ in high yield. The radical-mediated stannyldesulfonylation of 84 with $\mathrm{Bu}_{3} \mathrm{SnH} / \mathrm{AIBN}$ yielded (fluoro)vinyl stannanes $\mathbf{8 5}$. In the last step of synthesis, 85 underwent the halodestannylation ${ }^{35}$ with NIS or NBS or $\mathrm{Cl}_{2}$ to give 1-fluoro-1-iodo(86), 1-fluoro-1-bromo- (87) and 1-fluoro-1-chloroalkenes (88) (Scheme 29). It is noteworthy that dihaloalkenes of series $\mathbf{c}$ with a benzyloxy substituent at allylic carbon are structural analogues of the dihalohomovinyl nucleoside or ribofuranosyl precursors which also possesses oxygen atom at carbon $\delta$ from the $\alpha$-halovinyl carbon.

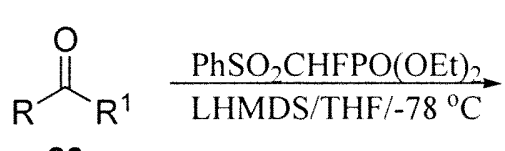

83<smiles></smiles>

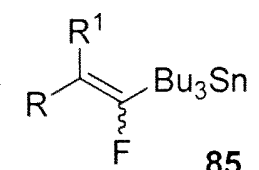<smiles>[R]/C(C)=C(/[R])[18F]</smiles>
$R^{1}$

\section{Compds $83-88$}

$R$ $\mathrm{Ph}$ H

b $\mathrm{PhCH}_{2} \mathrm{CH}_{2} \quad \mathrm{H}$

C $\mathrm{PhCH}_{2} \mathrm{OCH}_{2} \quad \mathrm{H}$ d $\mathrm{Ph}$ $\mathrm{CH}_{3}$

Scheme 29. Stereoselective synthesis of 1-fluoro-1-haloalkenes. 
Having the desired starting materials synthesized, we attempted couplings of the 1-fluoro-1-haloalkenes 86-88 with different types of primary alkylzinc bromides in the presence of $\mathrm{Pd}$ catalyst in benzene at $65^{\circ} \mathrm{C}$ (Scheme 30). Thus, treatment of 1-fluorovinyl iodide 86a $(E / Z, 95: 5)$ with 2 equiv. of primary alkylzinc bromide $\left[\mathrm{BrZn}\left(\mathrm{CH}_{2}\right)_{3} \mathrm{CO}_{2} \mathrm{Et}\right]$ in the presence of $\mathrm{Pd}\left(\mathrm{PPh}_{3}\right)_{4}$ in benzene $\left(65^{\circ} \mathrm{C}, 10 \mathrm{~h}\right)$ gave fluoro alkenoate $89 \mathrm{a}$ as a single $Z$ isomer $\left(J_{\mathrm{F}-\mathrm{H}(\text { trans })}=39.8 \mathrm{~Hz}\right)$ in $70 \%$ yield (Scheme 30; Table 3, entry 1$)$. Analogous treatment of $86 \mathbf{a}(E / Z, 95: 5)$ with alkylzinc bromides containing double bond $\left[\mathrm{BrZn}\left(\mathrm{CH}_{2}\right)_{3} \mathrm{CH}=\mathrm{CH}_{2}\right]$ or acetal functionality $\left[\mathrm{BrZn}\left(\mathrm{CH}_{2}\right)_{2} \mathrm{CH}\left(\mathrm{OCH}_{2}\right)_{2}\right]$ gave $\mathbf{9 0 a}(\mathrm{Z})$ or 91a $(Z)$, respectively (Table 3 , entries 5 and 6 ). The couplings occurred with retention of configuration via trans-selective alkylation, but $E / Z$ descriptors changed due to the change in Cahn-Ingold-Prelog priority at the reaction center carbon. The 1-fluorovinyl bromides $\mathbf{8 7} \mathbf{a}$ and chlorides $\mathbf{8 8 a}$ also underwent efficient couplings with $\mathrm{BrZn}\left(\mathrm{CH}_{2}\right)_{3} \mathrm{CO}_{2} \mathrm{Et}$ to give $89 \mathrm{a}(\mathrm{Z})$ in $70 \%$ and $80 \%$ yield (Table 3, entries 3 and 4).
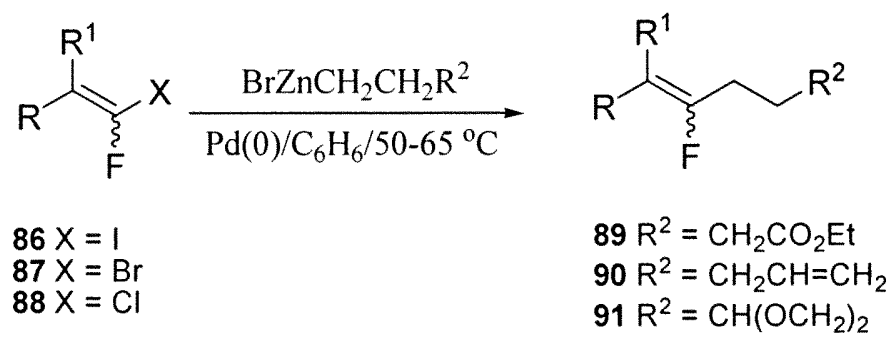

\begin{tabular}{cll} 
Compds 86-91 & $\mathrm{R}$ & $\mathrm{R}^{1}$ \\
\hline a & $\mathrm{Ph}$ & $\mathrm{H}$ \\
b & $\mathrm{PhCH}_{2} \mathrm{CH}_{2}$ & $\mathrm{H}$ \\
c & $\mathrm{PhCH}_{2} \mathrm{OCH}_{2}$ & $\mathrm{H}$ \\
d & $\mathrm{Ph}$ & $\mathrm{CH}_{3}$
\end{tabular}

Scheme 30. Couplings of 1-fluoro-1-haloalkenes with alkylzincs. 
In order to optimalize reaction conditions, we tested efficiency of various $\mathrm{Pd}$ catalysts for such Negishi monoalkylation (Scheme 31). We found that tris(dibenzylideneacetone)palladium $\left[\mathrm{Pd}_{2}(\mathrm{dba})_{3}\right] \quad$ and $1,4-$ bis(diphenylphosphinobutane)palladium chloride $\left[\mathrm{PdCl}_{2}(\mathrm{dppb})\right]$ gave smooth conversion of 86a into $91 \mathrm{a}$ in $2 \mathrm{~h}$ at $50{ }^{\circ} \mathrm{C} . \mathrm{Pd}\left(\mathrm{PPh}_{3}\right)_{4}$ effected only $11 \%$ conversion of 86a into 91a under analogous conditions. The $\mathrm{Pd}(\mathrm{OAc})_{2}$ and 1,1'-bis(diphenylphosphinoferrocene) palladium chloride $\left[\mathrm{PdCl}_{2}(\mathrm{dppf})\right]$ were also found to be less effective. In comparison with $\mathrm{Pd}\left(\mathrm{PPh}_{3}\right)_{4}$, coupling of $\mathbf{8 6 a}$ with $\mathrm{BrZn}\left(\mathrm{CH}_{2}\right)_{3} \mathrm{CO}_{2} \mathrm{Et}$ in the presence of $\mathrm{PdCl}_{2}(\mathrm{dppb})$ gave a higher yield of $\mathbf{8 9} \mathbf{a}(Z)(93 \%$, entry $2 \mathrm{vs}$. entry 1$)$ under milder conditions $\left(50{ }^{\circ} \mathrm{C}, 2\right.$ h). The cross-coupling reactions of the unconjugated 1-fluorovinyl halides $86 \mathbf{b}(E / Z$,

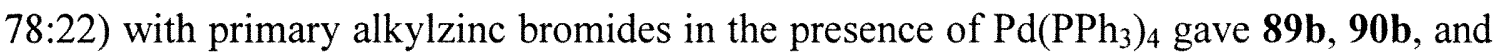
91b in high yields ( Table 3; entries 9, 13, and 14). The conversion of $\mathbf{8 6} \mathbf{b}$ into $\mathbf{8 9 b}$ was achieved in higher yield under milder conditions with $\mathrm{PdCl}_{2}(\mathrm{dppb})$ as catalyst ( Table 3 , entry 12).

The vinyl iodide 86c $(E / Z, 75: 25)$ with benzyloxymethyl substituent at carbon $\beta$ (analogue of the nucleoside precursor) reacted with $\mathrm{BrZn}\left(\mathrm{CH}_{2}\right)_{3} \mathrm{CH}=\mathrm{CH}_{2}\left[\mathrm{Pd}\left(\mathrm{PPh}_{3}\right)_{4}\right]$ to give the internal fluoroalkene $90 \mathrm{c}(Z)$ in moderate yield $(56 \%$, Table 3 , entry 17$)$ in addition to unchanged 86c with enriched $Z$ to $E$ ratio (56:44). It seems that the $\mathrm{PdCl}_{2}(\mathrm{dppb})$ catalyst not only increased the yield but also led to the formation of $90 \mathrm{c}$ as mixture of $E / Z$ isomers (20:80, $86 \%$; Table 3 , entry 18$)$. Also bromide $87 \mathbf{c}$ yielded $90 \mathbf{c}$ as $E / Z$ mixture in high yield (Table 3, entry 19 ).

The 1-fluorovinyl halides derived from acetophenone (series d) served as convenient starting material for the synthesis of multisubstituted alkenes. ${ }^{121}$ Thus, Pd- 
catalyzed monoalkylation of $\mathbf{8 6 d}(E / Z, 49: 51)$ in the presence of $\mathrm{Pd}\left(\mathrm{PPh}_{3}\right)_{4}$ produced 89d $(Z), 90 \mathbf{d}(Z)$, and $91 \mathbf{d}(Z)$ (Table 3, entries 20, 22, 23). Analogous coupling of 86d with more reactive $\mathrm{PdCl}_{2}(\mathrm{dppb})$ gave 89d as a mixture of $E / Z$ (16:84) isomers (Table 3, entry 21$)$.

In order to learn more about the stereochemistry of coupling reactions, the pure $E$ isomer and a mixture enriched in $Z$ isomer $(E / Z, 15: 85)$ of fluoro(iodo)alkenes $86 \mathbf{b}$ were synthesized by separation of the corresponding (fluoro)vinyl stannanes $\mathbf{8 5 \mathbf { b }}$ followed by the stereospecific iododestannylation. Treatment of $\mathbf{8 6} \mathbf{b}(E)$ with $\mathrm{BrZn}\left(\mathrm{CH}_{2}\right)_{3} \mathrm{CO}_{2} \mathrm{Et}$ or $\mathrm{BrZn}\left(\mathrm{CH}_{2}\right)_{2} \mathrm{CH}\left(\mathrm{OCH}_{2}\right)_{2}\left[\mathrm{Pd}\left(\mathrm{PPh}_{3}\right)_{4} / 12 \mathrm{~h} / 65^{\circ} \mathrm{C}\right]$ resulted in smooth conversion (GC/MS, ${ }^{19} \mathrm{~F} \mathrm{NMR}$ ) to $89 \mathrm{~b}(Z)$ or $91 \mathrm{~b}(Z)$ with the isolated yields of $88 \%$ and $89 \%$, respectively (Table 3, entries 10 and 15). On the other hand, analogous Negishi treatment of $86 \mathbf{b}(E / Z$, $15: 85)$ yielded $89 \mathrm{~b}(Z)$ or $91 \mathrm{~b}(Z)$ in $14 \%$ ( $96 \%$ conversion of $E$ isomers) while the corresponding $89 \mathrm{~b}(E)$ or $91 \mathrm{~b}(E)$ were not formed (Scheme 32). Prolonged reaction time and harsher condition resulted in decomposition of the $86 \mathbf{b}(Z)$ isomer (GC/MS, ${ }^{19} \mathrm{~F}$ NMR). 
Table 3. Pd-catalyzed alkylation of 1-fluoro-1-haloalkenes $86-88^{\mathrm{a}}$.

\begin{tabular}{|c|c|c|c|c|c|c|}
\hline Entry & substrate & $E / Z$ & product (Z) & time $(h)$ & yield $^{b}$ & yield $^{c}$ \\
\hline 1 & $86 a$ & $95 / 5$ & $89 a$ & 10 & $70 \%$ & $74 \%$ \\
\hline 2 & $86 a$ & $95 / 5$ & $89 \mathrm{a}^{d}$ & 2 & $93 \%$ & $97 \%$ \\
\hline 3 & $87 a$ & $93 / 7$ & $89 a$ & 10 & $70 \%$ & $75 \%$ \\
\hline 4 & $88 \mathrm{a}$ & $93 / 7$ & $89 a$ & 10 & $80 \%$ & $86 \%$ \\
\hline 5 & $86 a$ & $95 / 5$ & $90 \mathbf{a}^{e}$ & 10 & $65 \%$ & $69 \%$ \\
\hline 6 & $86 a$ & $95 / 5$ & $91 \mathrm{a}$ & 12 & $90 \%$ & $94 \%$ \\
\hline 7 & $86 a$ & $95 / 5$ & $91 a^{f}$ & 2 & $92 \%$ & $96 \%$ \\
\hline 8 & $86 a$ & $95 / 5$ & $91 \mathrm{a}^{d}$ & 2 & $94 \%$ & $98 \%$ \\
\hline 9 & $86 b$ & $78 / 22$ & $89 \mathrm{~b}$ & 24 & $60 \%$ & $78 \%$ \\
\hline 10 & $86 b$ & $100 / 0$ & $89 \mathrm{~b}$ & 12 & $88 \%$ & $88 \%^{g}$ \\
\hline 11 & $86 b$ & $15 / 85$ & $89 \mathrm{~b}$ & 24 & $14 \%$ & $96 \%$ \\
\hline 12 & $86 b$ & $84 / 16$ & $89 b^{d}$ & 8 & $82 \%$ & $98 \%$ \\
\hline 13 & $86 b$ & $78 / 22$ & $90 b^{h}$ & 20 & $76 \%$ & $98 \%$ \\
\hline 14 & $86 b$ & $78 / 22$ & $91 \mathrm{~b}$ & 20 & $74 \%$ & $94 \%$ \\
\hline 15 & $86 b$ & $100 / 0$ & $91 \mathrm{~b}$ & 12 & $89 \%$ & $89 \%{ }^{i}$ \\
\hline 16 & $86 \mathrm{~b}$ & $15 / 85$ & $91 \mathrm{~b}$ & 24 & $14 \%$ & $96 \%$ \\
\hline 17 & $86 c$ & $75 / 25$ & $90 \mathrm{c}$ & 48 & $56 \% \%^{j}$ & $74 \%$ \\
\hline 18 & $86 c$ & $67 / 33$ & $90 \mathbf{c}^{d, k}$ & 4 & $86 \%$ & \\
\hline 19 & $87 c$ & $77 / 23$ & $\mathbf{9 0 \mathbf { c } ^ { d , k }}$ & 6 & $84 \%$ & \\
\hline 20 & $86 d$ & $49 / 51$ & $89 d$ & 24 & $45 \%$ & $94 \%$ \\
\hline 21 & $86 d$ & $49 / 51$ & $89 \mathbf{d}^{d, l}$ & 8 & $60 \%$ & \\
\hline 22 & $86 d$ & $49 / 51$ & 90d & 24 & $45 \%$ & $92 \%$ \\
\hline 23 & $86 d$ & $49 / 51$ & 91d & 24 & $46 \%$ & $90 \%$ \\
\hline
\end{tabular}

${ }^{a} \mathrm{Pd}\left(\mathrm{Ph}_{3} \mathrm{P}\right)_{4}$ was used as a catalyst unless otherwise specified $\left(50-65{ }^{\circ} \mathrm{C}\right) .{ }^{b}$ isolated yield. ${ }^{c}$ isolated yield based on the conversion of the $E$ isomer only. ${ }^{d} \mathrm{PdCl}_{2}(\mathrm{dppb})$ catalyst. ${ }^{e}(Z, Z)-2,3$-difluoro-1,4diphenyl-1,3-butadiene 94 was also isolated $(8 \% ; 16 \%$ consumption of $86 a) .{ }^{f} \operatorname{Pd}_{2}(\mathrm{dba})_{3}$ catalyst. ${ }^{g} 96 \%$ based on GC-MS. ${ }^{h}(Z)-1$-fluoro-4-phenyl-1-butene, $E$ isomer of $90 \mathrm{~b}$ and (Z,Z)-4,5-difluoro-1,8-diphenyl3,5 -octadiene was also detected in crude reaction mixture ( ${ }^{19} \mathrm{~F}$ NMR). ${ }^{\prime} 98 \%$ based on GC-MS. ' $56 \%$ based on ${ }^{19} \mathrm{~F} \mathrm{NMR} .{ }^{k}(E / Z, 20: 80) .{ }^{~}\left(E / Z, 16: 84\right.$; based on ${ }^{19} \mathrm{~F} \mathrm{NMR}$ and GC-MS). 


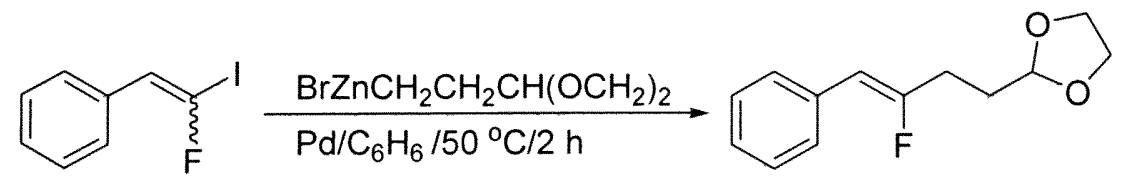

86a $(E / Z, 95: 5)$

$91 \mathrm{a}(Z)$

\begin{tabular}{cl} 
Catalyst $^{a}$ & Yield $^{b, c}$ \\
\hline $\mathrm{Pd}\left(\mathrm{PPh}_{3}\right)_{4}$ & $11 \%$ \\
$\mathrm{PdCl}_{2}(\mathrm{dppf})$ & $8 \%$ \\
$\mathrm{Pd}(\mathrm{OAc})_{2}$ & $75 \%^{d}$ \\
$\mathrm{Pd}_{2}(\mathrm{dba})_{3}$ & $93 \%^{\mathrm{e}}$ \\
$\mathrm{PdCl}_{2}(\mathrm{dppb})$ & $95 \%^{f}$
\end{tabular}

Key: ${ }^{a} 5 \%$ molar; ${ }^{b} \mathrm{GC} / \mathrm{MS}$ and ${ }^{19} \mathrm{~F}$ NMR; ${ }^{c}$ only $Z$ product was detected;

${ }^{d} 95 \%$ after $3.5 \mathrm{~h}$; ${ }^{e}$ Isolated yield $92 \% ;{ }^{f}$ Isolated yield $94 \%$.

Scheme 31. Effect of the Pd catalyst on the efficiency of Negishi coupling<smiles>FC(I)=CCCc1ccccc1</smiles>

$86 \mathrm{~b}(E)$<smiles>FC(I)=CCCc1ccccc1</smiles>

$\mathbf{8 6 b}(E / Z ; 15: 85)$

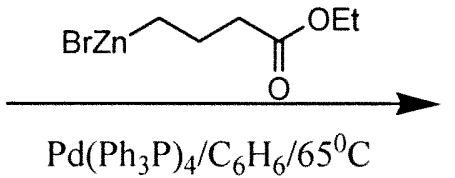

$\mathrm{Pd}\left(\mathrm{Ph}_{3} \mathrm{P}\right)_{4} / \mathrm{C}_{6} \mathrm{H}_{6} / 65^{\circ} \mathrm{C}$

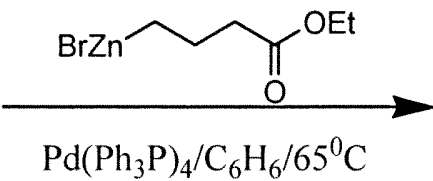

$\mathrm{Pd}\left(\mathrm{Ph}_{3} \mathrm{P}\right)_{4} / \mathrm{C}_{6} \mathrm{H}_{6} / 65^{\circ} \mathrm{C}$<smiles>CCOC(=O)CCC/C(F)=C/CCc1ccccc1</smiles>

$89 \mathrm{~b}(Z), 88 \%$ isolated yield $96 \%$ based on GC-MS<smiles>CCOC(=O)CCC/C(F)=C/CCc1ccccc1</smiles>

$89 b(Z), 14 \%$

$96 \%$ conversion of $E$ isomer

Scheme 32. Establishing the stereochemistry of couplings with 1,1-dihaloalkenes. 
Generally, we only observed formation (above detection limit ${ }^{122}$ of $1-2 \%,{ }^{19} \mathrm{~F}$ NMR) of the corresponding $E$ isomers via cis-couplings in a few instances (Table 3, entry $13,18,19,21)$. For example alkylation of $\mathbf{8 6} \mathbf{c}$ (iodide) and $\mathbf{8 7} \mathbf{c}$ (bromide) in the presence of $\mathrm{PdCl}_{2}(\mathrm{dppb})$ produced $90 \mathrm{c}$ as $E / Z(20: 80)$ mixture. These results are in agreement with trans-selective mono cross-coupling of 1,1-dihaloalkenes reported previously. ${ }^{72,76,100,123}$ Burton and coworkers showed that trans selectivity with 1-bromo-1-fluoroalkenes originate in oxidative addition step since formation of the $E$-palladium complex is faster than the formation of the $Z$-palladium complex which is hampered by steric hinderence of vicinal cis-substituent. ${ }^{123 a}$ They applied this finding for the kinetic resolution of the $E$ and $Z$ coupling products. ${ }^{123}$ The major by-product isolated from the coupling reactions resulted from the reductive homocoupling of dihalide components. For example, selfcoupling product of $\mathbf{8 6 a}$, e.g., (E,E)-2,3-difluoro-1,4-diphenyl-1,3-butadiene 94, was isolated in $8 \%$ yield from the reaction of $86 \mathbf{a}$ with $\mathrm{BrZn}\left(\mathrm{CH}_{2}\right)_{3} \mathrm{CH}=\mathrm{CH}_{2}$ (Table 3, entry $5)$.

We have also examined the Pd-catalyzed 1,1-dihaloalkenyl coupling with branched alkylzincs. Thus, $\mathrm{PdCl}_{2}(\mathrm{dppb})$ was found to be effective for monoalkylation of 86a $(E / Z, 95: 5)$ with tert $-\operatorname{BuZnBr}(\mathbf{9 2 a})$ to provide 93a $\left(80 \% ; 3 \mathrm{~h}, 50{ }^{\circ} \mathrm{C}\right.$; Scheme 33$)$. The $\mathrm{Pd}_{2}(\mathrm{dba})_{3}$ and $\mathrm{Pd}\left(\mathrm{PPh}_{3}\right)_{4}$ catalysts were less effective leading to the formation of the significant amount of self-coupling (E,E)-2,3-difluoro-1,4-diphenyl-1,3-butadiene 94 byproduct. Interestingly, attempted couplings of $\mathbf{8 6 a}(E / Z, 95: 5)$ with secondary 2- and 3pentylzinc bromide $(\mathbf{9 2} \mathbf{b}, \mathbf{c})$ in addition to various amount of desired products $\mathbf{9 3 b}$ and 93c gave also isomerization byproduct $93 \mathbf{d}(35-70 \%)$ in addition to selfcoupled diene 94 and reduced ( $Z$ )- $\beta$-fluorostyrene (in some cases). Formation of byproducts derived from 
isomerization of the alkyl group (secondary to primary) during Negishi cross-coupling reaction is known. ${ }^{123 c, 124}$

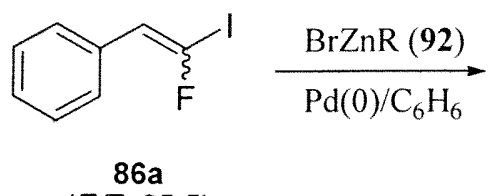

$(E / Z, 95: 5)$<smiles>[R]/C(C)=C/c1ccccc1</smiles>

93<smiles>FC(C=Cc1ccccc1)=Cc1ccccc1</smiles>

94

Compounds 92, 93: Series a $\mathrm{R}=$ tert-Bu

b $R=2$-pentyl

c $R=3$-pentyl

d $\mathrm{R}=n-\mathrm{Bu}$

Scheme 33. Couplings with branched alkylzincs.

\subsubsection{Coupling with 1,1-dichloro- and 1,1-dibromoalkenes}

In order to investigate the differentiation of the two identical halogens in 1,1dihaloalkenes for the selective monoalkylation with alkylzincs, we attempted Pdcatalyzed selective monosubstitution of 1,1-dichloro- and 1,1-dibromoalkenes with alkylzinc reagents. The corresponding 1,1-dichloro- and 1,1-dibromoalkenes were prepared using Rabinowitz and Marcus ${ }^{125}$ procedure. Thus, a solution of triphenylphosphine and the corresponding carbonyl compound in carbon tetrachloride (or carbon tetrabromide) were heated at $60{ }^{\circ} \mathrm{C}$ for $3 \mathrm{~h}$. Analysis of GC-MS spectrum revealed that the carbonyl compound disappeared while $\beta, \beta$-dihaloalkenes 96-97 were formed (Scheme 34). 


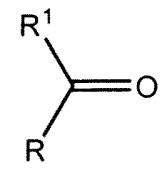

95

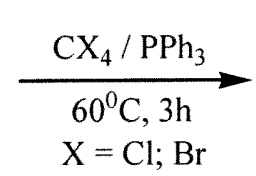

$\mathrm{X}=\mathrm{Cl} ; \mathrm{Br}$

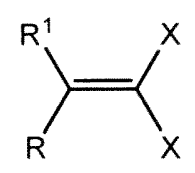

$$
96 \mathrm{X}=\mathrm{Cl}
$$$$
97 \mathrm{X}=\mathrm{Br}
$$

\begin{tabular}{ccc} 
Cmpds 96-97 & $\mathrm{R}$ & $\mathrm{R}^{1}$ \\
\hline a & $\mathrm{Ph}$ & $\mathrm{H}$ \\
b & $\left(\right.$ (4) $\mathrm{CH}_{3} \mathrm{OPh}$ & $\mathrm{H}$ \\
c & $\mathrm{Ph}$ & $\mathrm{CH}_{3}$
\end{tabular}

Scheme 34. Synthesis of 1,1-dichloro- and 1,1-dibromoalkenes.

In order to find the optimal reaction conditions for the monoalkylation reaction, we conducted a systematic screening of Pd-catalysts (Scheme 35). Screening of the Pdcatalyst in the monoalkylation of $\beta, \beta$-dichloro-4-methoxystyrene $98 \mathbf{b}$ revealed that $\mathrm{PdCl}_{2}(\mathrm{dppf})$ was the best catalyst for this reaction giving the desired monocoupling product in $70 \%$ isolated yield. $\mathrm{PdCl}_{2}(\mathrm{dppb})$ effected conversion of $\mathbf{9 6 \mathbf { b }}$ into $\mathbf{9 8 \mathbf { b }}$ in $63 \%$ yield under analogous conditions. On the other hand $\mathrm{Pd}\left(\mathrm{PPh}_{3}\right)_{4}, \mathrm{Pd}(\mathrm{OAc})_{2}$ and $\mathrm{Pd}_{2}(\mathrm{dba})_{3}$ were found to be less effective. It is worthy to note that the monoalkylation reaction was improved in the presence of DPEPhos [bis(o-diphenylphosphanylphenylether) ${ }^{126}$ as an extra ligand.

Negishi and $\operatorname{Tan}^{76 \mathrm{~b}}$ explained that DPEPhos plays an important role in the Pdmonoalkylation reaction and it is possible that the ethereal oxygen atom of DPEPhos may extert a chelation effect to facilitate the dissociation of alkenes (see section 1.3.4). Once the reaction conditions were established, we examined the Pd-catalyzed monocoupling 
using different 1,1-dichloro- and 1,1-dibromoalkenes (Scheme 36, Table 4). In agreement with literature reports, ${ }^{76}$ the Pd-catalyzed monoalkylation of 1,1-dihaloalkenes was found to be trans-selective.<smiles>CCOC(=O)CCC/C(Cl)=C/c1ccc(OC)cc1</smiles>

\begin{tabular}{lc} 
Catalyst $^{\mathrm{a}}$ & Yield $^{\mathrm{b}, \mathrm{c}}$ \\
\hline $\mathrm{PdCl}_{2}(\mathrm{dppf})$ & 70 \\
$\mathrm{PdCl}_{2}(\mathrm{dppb})$ & 63 \\
$\mathrm{Pd}\left(\mathrm{PPh}_{3}\right)_{4}$ & 55 \\
$\mathrm{Pd}(\mathrm{OAc})_{2}$ & 15 \\
$\mathrm{Pd}_{2}(\mathrm{dba})_{3}$ & 9
\end{tabular}

Key: ${ }^{\text {a }} 5 \%$ molar. ${ }^{b}$ Isolated yields..$^{c}$ Only $Z$ product was detected

Scheme 35. Screening of Pd catalyst for the monoalkylation reaction. 


$$
\begin{array}{lll}
96 \mathrm{X}=\mathrm{Cl} \\
97 \mathrm{X}=\mathrm{Br} & \begin{array}{l}
98 \mathrm{X}=\mathrm{Cl} \\
99 \mathrm{X}=\mathrm{Br}
\end{array}
\end{array}
$$

\begin{tabular}{|c|c|c|c|c|c|c|c|}
\hline Entry & Substrate & $\begin{array}{l}\text { Conditions } \\
\text { Catalyst }\end{array}$ & $\begin{array}{l}\text { Conditions } \\
\text { Ligand }\end{array}$ & $\begin{array}{l}\text { Conditions } \\
\text { Time }\end{array}$ & $\begin{array}{l}\text { Yield }(\%) \\
\text { Mono }\end{array}$ & $\begin{array}{l}\text { Yield }(\%) \\
\text { Dialkylated } \\
\end{array}$ & $\begin{array}{l}\text { Yield }^{a} \\
\text { Reduced }\end{array}$ \\
\hline 1 & $96 a$ & $\mathrm{PdCl}_{2}(\mathrm{dppf})$ & & 14 & 65 & 0 & 22 \\
\hline 2 & $96 a$ & $\mathrm{PdCl}_{2}(\mathrm{dppb})$ & & 12 & 53 & 27 & 15 \\
\hline 3 & $96 a$ & $\mathrm{Pd}\left(\mathrm{PPh}_{3}\right)_{4}$ & & 12 & 0 & 68 & 28 \\
\hline 4 & $96 \mathrm{~b}$ & $\mathrm{PdCl}_{2}$ (dppf) & DPEPhos & 8 & 70 & 27 & 0 \\
\hline 5 & $96 b$ & $\mathrm{PdCl}_{2}(\mathrm{dppb})$ & DPEPhos & 8 & 63 & 27 & 10 \\
\hline 6 & $96 b$ & $\mathrm{Pd}\left(\mathrm{PPh}_{3}\right)_{4}$ & DPEPhos & 8 & 55 & 35 & 10 \\
\hline 7 & $96 c$ & $\mathrm{PdCl}_{2}(\mathrm{dppb})$ & DPEPhos & 10 & 0 & 90 & 10 \\
\hline 8 & $97 a$ & $\mathrm{PdCl}_{2}(\mathrm{dppf})$ & & 10 & 0 & 69 & 28 \\
\hline 9 & $97 a$ & $\mathrm{PdCl}_{2}(\mathrm{dppb})$ & & 10 & 0 & 75 & 24 \\
\hline 10 & $97 a$ & $\mathrm{Pd}\left(\mathrm{PPh}_{3}\right)_{4}$ & & 10 & 0 & 60 & 38 \\
\hline 11 & $97 b$ & $\mathrm{PdCl}_{2}(\mathrm{dppf})$ & DPEPhos & 7 & 47 & 52 & 0 \\
\hline 12 & $97 \mathrm{~b}$ & $\mathrm{PdCl}_{2}(\mathrm{dppb})$ & DPEPhos & 7 & 0 & 78 & 21 \\
\hline 13 & $97 \mathrm{~b}$ & $\mathrm{Pd}\left(\mathrm{PPh}_{3}\right)_{4}$ & DPEPhos & 10 & 40 & 59 & 0 \\
\hline 14 & $97 b$ & $\mathrm{Pd}\left(\mathrm{PPh}_{3}\right)_{4}$ & & 10 & 0 & 72 & 26 \\
\hline 15 & $97 \mathrm{c}$ & $\mathrm{PdCl}_{2}(\mathrm{dppb})$ & DPEPhos & 12 & 0 & 87 & 10 \\
\hline
\end{tabular}

\begin{tabular}{lll} 
Cmpds. 96-101 & $\mathrm{R}^{1}$ & $\mathrm{R}^{2}$ \\
\hline a & $\mathrm{H}$ & $\mathrm{H}$ \\
b & $\mathrm{H}$ & $\mathrm{OCH}_{3}$ \\
c & & \\
& $\mathrm{CH}_{3}$ & $\mathrm{H}$
\end{tabular}

Scheme 36. Pd-catalyzed trans-selective monoalkylation of 1,1-dichloro- and 1,1-dibromoalkenes with alkyl zinc reagent.

Table 4. Pd-catalyzed monoalkylation of 1,1-dichloro- and 1,1-dibromoalkenes.

${ }^{a}$ isolated yield 
We found that the $\beta, \beta$-dichlorostyrene 96a coupled with $\mathrm{BrZn}\left(\mathrm{CH}_{2}\right)_{3} \mathrm{CO}_{2}$ in the presence of $\mathrm{PdCl}_{2}(\mathrm{dppf})$ to give the desired trisubstituted chloroalkene $\mathbf{9 8 \mathbf { a } ^ { 1 2 1 b }}(\mathrm{Z}, 65 \%$ Table 4, entry 1) in addition to the monocoupled/reduced byproduct 101a (22\%). Analogous coupling of $96 \mathbf{a}$ in the presence of $\mathrm{PdCl}_{2}(\mathrm{dppb})$ also produced $98 \mathbf{a}(Z, 53 \%$, Table 4, entry 2). Besides the desired monoalkylated product 98a, the formation of dialkylated byproduct 100a (27\%) and reduced byproduct 101a (15\%) was also observed. Similar couplings with more reactive $\beta, \beta$-dibromostyrene 97a did not produced the desired trisubstituted bromoalkene 99a. In fact coupling of 97a with $\mathrm{BrZn}\left(\mathrm{CH}_{2}\right)_{3} \mathrm{CO}_{2}$ in the presence of $\mathrm{PdCl}_{2}(\mathrm{dppf})$ or $\mathrm{PdCl}_{2}(\mathrm{dppb})$ produced mainly the dialkylated 100a $(69 \%$ or $75 \%$, Table 4 , entries 7 and 8 ) in addition to the reduced by-product $101 \mathbf{a}$.

We found that the addition of an extra ligand such as DPEPhos (bis-odiphenylphosphanylphenylether) can control the Pd-catalyzed monoalkylation reaction of 1,1-dihaloalkenes. Thus, treatment of $\mathbf{9 6} \mathbf{b}$ with $\mathrm{BrZn}\left(\mathrm{CH}_{2}\right)_{3} \mathrm{CO}_{2}$ in the presence of $\mathrm{PdCl}_{2}(\mathrm{dppf})$ as a catalyst and DPEPhos as a ligand gave the desired trisubstituted chloroalkene $\mathbf{9 8 b}$ in a higher yield ( $Z, 70 \%$ Table 4 , entry 4$)$. The major improvement of using DPEPhos was observed in coupling of $\beta, \beta$-dibromostyrene derivative $\mathbf{9 7} \mathbf{b}$ with an alkylzinc reagent. Thus, treatment of 97b with $\mathrm{BrZn}\left(\mathrm{CH}_{2}\right)_{3} \mathrm{CO}_{2} / \mathrm{PdCl}_{2}(\mathrm{dppf})$ and DPEPhos as a ligand afforded the desired trisubstituted bromoalkene $99 \mathrm{~b}(Z, 47 \%$, Table 4 , entry 11) in addition to the dialkylated by product $\mathbf{1 0 0 b}$. Analysis of ${ }^{1} \mathrm{H}$ NMR and GCMS spectra showed the characteristic peaks for a trisubstituted bromoalkene. Analogous coupling of $\mathbf{9 7 \mathbf { b }}$ with organozinc reagent in the presence of $\mathrm{Pd}\left(\mathrm{PPh}_{3}\right)_{4}$ as a catalyst and DPEPhos as ligand also furnished the desired bromoalkene $99 \mathbf{b}(Z, 40 \%$, Table 4 , entry 13). It is noteworthy that coupling of $\mathbf{9 7} \mathbf{b}$ using only $\mathrm{Pd}\left(\mathrm{PPh}_{3}\right)_{4}$ (without ligand) did not 
afford 99b (Table 4, entry 14). Treatment of 1,1-dihaloalkenes derived from the acetophenone (96c or 97c) with $\mathrm{PdCl}_{2}(\mathrm{dppb})$ and DPEPhos yielded mainly the dialkylated products (Table 4, entry 7 and 15).

Generally speaking, the major byproduct isolated from the Pd-catalyzed transselective monoalkylation of 1,1-dihaloalkenes was the dialkylated byproduct. It is clear that competitive formation of this type of byproduct is the major side reaction to be minimized in future work. 


\section{EXPERIMENTAL SECTION}

\subsection{General procedures}

UV spectra were measured with solutions in $\mathrm{MeOH} .{ }^{1} \mathrm{H}(400 \mathrm{MHz}$ and 600 $\mathrm{MHz}),{ }^{13} \mathrm{C}(100 \mathrm{MHz})$ and ${ }^{19} \mathrm{~F}$ NMR $(376.4 \mathrm{MHz})$ spectra were determined with solutions in $\mathrm{CDCl}_{3}$ unless otherwise noted. Mass spectra (MS) were obtained with atmospheric pressure chemical ionization (APCI) technique and HRMS using AP-ESI mode unless otherwise noted. Reagent grade chemicals were used, and solvents were dried by reflux over and distillation from $\mathrm{CaH}_{2}$ (except THF/potassium) under an argon atmosphere. TLC was performed with Merck kieselgel $60-\mathrm{F}_{254}$ sheets with $\mathrm{MeOH} / \mathrm{CHCl}_{3}$ (1:19), EtOAc/hexane $(2: 1)$ and $\mathrm{EtOAc} / \mathrm{i}-\mathrm{PrOH} / \mathrm{H}_{2} \mathrm{O}(4: 1: 2$, upper layer) as developing systems. Products were detected with $254 \mathrm{~nm}$ light or by development of color with $\mathrm{Ce}\left(\mathrm{SO}_{4}\right)_{2} /\left(\mathrm{NH}_{4}\right)_{6} \mathrm{Mo}_{7} \mathrm{O}_{24} \bullet 4 \mathrm{H}_{2} \mathrm{O} / \mathrm{H}_{2} \mathrm{SO}_{4} / \mathrm{H}_{2} \mathrm{O}$ or $\mathrm{I}_{2}$ or $10 \% \mathrm{H}_{2} \mathrm{SO}_{4} / \mathrm{MeOH}$. Merck kieselgel 60 (230-400 mesh) was used for column chromatography. HPLC purifications were performed using $X T$ erra ${ }^{\circledR}$ preparative $\mathrm{RP}_{18} \mathrm{OBD}^{\mathrm{TM}}$ column $(5 \mu \mathrm{m} 19 \times 150 \mathrm{~mm})$ with gradient program using $\mathrm{CH}_{3} \mathrm{CN} / \mathrm{H}_{2} \mathrm{O}$ as a mobile phase. Purity and identity of some products (crude and/or purified) were established using a Hewlett-Packard (HP) GC/MS (EI) system with a HP 5973 mass selective detector [capillary column HP-5MS (30 m $\times$

$0.25 \mathrm{~mm} \times 25 \mu \mathrm{m})]$. Elemental analyses were determined by Galbraith Laboratories, Knoxville, TN. 


\subsection{Synthesis}

$\mathbf{L}^{-2} \mathbf{2}^{\prime} \mathbf{3}^{\prime}$ - $\boldsymbol{O}$-Isopropylideneadenosine $\mathbf{( 5 3 )}$. L-Adenosine ${ }^{103} \quad \mathbf{5 2}, 200 \mathrm{mg}, 0.75$ mmol) was suspended in dried acetone $(6 \mathrm{~mL})$ containing $p$-toluenesulfonic acid monohydrate $(470 \mathrm{mg}, 2.5 \mathrm{mmol})$. Triethyl orthoformate $(1.5 \mathrm{~mL}, 1.34 \mathrm{mg}, 9.0 \mathrm{mmol})$ was then added over a period of 10 to $20 \mathrm{~min}$ at ambient temperature with vigorous mechanical stirring until a clear solution was obtained. After $18 \mathrm{~h}$, water $(4.5 \mathrm{~mL})$ and concentrated ammonium hydroxide $(0.1 \mathrm{~mL}$ ) were added (to $\mathrm{pH} \sim 7-8)$. Volatiles were evaporated and the residue was column chromatographed (EtOAc $\rightarrow 5 \% \mathrm{MeOH} / \mathrm{EtOAc}$ ) to give 53 (206 $\mathrm{mg}, 90 \%$ ) with spectroscopic data identical to the commercial sample of 2',3'-O-isopropylideneadenosine.

L-2',3'-O-Isopropylideneadenosine-5'-carboxaldehyde Oximes (54). A solution of 53 (100 mg, $0.33 \mathrm{mmol}$ ) and $N, N^{\prime}$-dicyclohexylcarbodiimide (DCC; $235 \mathrm{mg}$, $1.13 \mathrm{mmol})$ in dried DMSO $(1.5 \mathrm{~mL})$ was stirred under argon at ambient temperature. The $\mathrm{Cl}_{2} \mathrm{CHCO}_{2} \mathrm{H}(0.013 \mathrm{~mL}, 21 \mathrm{mg}, 0.16 \mathrm{mmol})$ was then added and stirring was continued for $90 \mathrm{~min}$. Pyridine $(0.5 \mathrm{~mL})$ and $\mathrm{NH}_{2} \mathrm{OH} \bullet \mathrm{HCl}(226 \mathrm{mg}, 3.25 \mathrm{mmol})$ were added to the solution of the crude L-adenosine-5'-carboxaldehyde and stirring was continued at ambient temperature overnight. Volatiles were evaporated, $\mathrm{CHCl}_{3}$ was added and the precipitated dicyclohexylurea (DCU) was filtered. The mother liquor was partitioned $\left(1 \% \mathrm{AcOH} / \mathrm{H}_{2} \mathrm{O} / / \mathrm{CHCl}_{3}\right)$ and the aqueous layer was extracted $\left(4 \times \mathrm{CHCl}_{3}\right)$. The combined organic phase was washed $\left(\mathrm{NaHCO}_{3} / \mathrm{H}_{2} \mathrm{O}\right.$, brine), dried $\left(\mathrm{Na}_{2} \mathrm{SO}_{4}\right)$, and was concentrated and column chromatographed $\left(2 \rightarrow 4 \% \mathrm{MeOH} / \mathrm{CHCl}_{3}\right)$ to give $\mathbf{5 4}(E / Z$, $\sim 6: 1 ; 83 \mathrm{mg}, 80 \%): \mathrm{MS}(\mathrm{APCI}) \mathrm{m} / z 321\left(100, \mathrm{MH}^{+}\right)$and other spectroscopic data as described for D-enantiomer. ${ }^{105}$ 
L-Adenosine-5'-carboxaldehyde oximes (55). A solution of 54 (83 $\mathrm{mg}, 0.08$ mmol) in $\mathrm{CF}_{3} \mathrm{CO}_{2} \mathrm{H} / \mathrm{H}_{2} \mathrm{O}(9: 1,5 \mathrm{~mL})$ was stirred at $0{ }^{\circ} \mathrm{C}$ for 45 min under argon. Volatiles were evaporated and the residue was coevaporated $(3 \times$ toluene $)$ and then column chromatographed (EtOAc $\rightarrow 8 \% \mathrm{MeOH} / \mathrm{EtOAc})$ to give $\mathbf{5 5}(E / Z, \sim 6: 1 ; 20 \mathrm{mg}$, $89 \%$ ) as an amorphous white solid: MS (APCI) $m / z 281\left(100, \mathrm{MH}^{+}\right)$; UV (MeOH) $\max$ $260 \mathrm{~nm}(\varepsilon 14100), \min 228(\varepsilon 4000) .{ }^{1} \mathrm{H}$ NMR $\left(\mathrm{MeOH}-d_{4}\right)$ for $\mathbf{5 5}(E) \delta 4.50(\mathrm{t}, J=4.7,1$, $\left.\mathrm{H}^{\prime}\right), 4.58\left(\mathrm{dd}, J=6.9,4.4 \mathrm{~Hz}, 1, \mathrm{H} 4^{\prime}\right), 4.83\left(\mathrm{t}, J=5.0 \mathrm{~Hz}, 1, \mathrm{H} 2^{\prime}\right), 6.06(\mathrm{~d}, J=5.0 \mathrm{~Hz}, 1$, H1'), $7.64\left(\mathrm{~d}, J=6.9 \mathrm{~Hz}, 1, \mathrm{H} 5^{\prime}\right), 8.24(\mathrm{~s}, 1, \mathrm{H} 2), 8.32(\mathrm{~s}, 1, \mathrm{H} 8) . \quad 55(Z) \delta 4.38(\mathrm{dd}, J=$ 4.6, 1.5 Hz, 1, H3'), 5.08 (dd, $\left.J=7.5,4.8 \mathrm{~Hz}, 1, \mathrm{H} 2^{\prime}\right), 5.22\left(\mathrm{dd}, J=5.2,1.6 \mathrm{~Hz}, 1, \mathrm{H} 4^{\prime}\right)$, $6.03\left(\mathrm{~d}, J=7.5 \mathrm{~Hz}, 1, \mathrm{H1} 1^{\prime}\right), 7.28\left(\mathrm{~d}, J=5.2 \mathrm{~Hz}, 1, \mathrm{H} 5^{\prime}\right), 8.24$ (s, 1, H2), 8.32 (s, 1, H8).

6- $N, N$-Dibenzoyl-5'-deoxy-5'-methylene-2,3-O-isopropylideneadenosine (61b). Benzoyl chloride $(323.4 \mathrm{mg}, 0.23 \mathrm{mmol})$ was added dropwise to a stirred solution of $\mathbf{6 0}^{35,37}(350 \mathrm{mg}, 1.15 \mathrm{mmol})$ in pyridine $(5 \mathrm{~mL})$ at $0{ }^{\circ} \mathrm{C}$ (ice bath) and the resulting mixture was stirred overnight at ambient temperature. $\mathrm{NaHCO}_{3} / \mathrm{H}_{2} \mathrm{O}(3 \mathrm{~mL})$ was added and the volatiles were evaporated. The residue was partitioned $\left(\mathrm{HCl} / \mathrm{H}_{2} \mathrm{O} / \mathrm{EtOAc}\right)$ and the organic layer was washed $\left(\mathrm{NaHCO}_{3}\right.$, brine), dried $\left(\mathrm{Na}_{2} \mathrm{SO}_{4}\right)$ and evaporated. Column chromatography $\left(30 \rightarrow 50 \%\right.$ EtOAc/hexanes) gave 61b $(560 \mathrm{mg}, 97 \%):{ }^{1} \mathrm{H}$ NMR $\delta 1.41$ (s, 3, $\left.\mathrm{CH}_{3}\right), 1.65\left(\mathrm{~s}, 3, \mathrm{CH}_{3}\right), 4.73-4.75\left(\mathrm{~m}, 1, \mathrm{H} 4^{\prime}\right), 4.95\left(\mathrm{dd}, J=3.3,6.2 \mathrm{~Hz}, 1, \mathrm{H} 3^{\prime}\right), 5.14$ ("d", $J=10.4 \mathrm{~Hz}, 1, \mathrm{H6}$ "), 5.22 ("d", $J=17.1 \mathrm{~Hz}, 1, \mathrm{H6}$ ), 5.50 (dd, $J=1.9,6.3 \mathrm{~Hz}, 1$, H2'), 5.90 (ddd, $\left.J=6.8,10.4,17.2 \mathrm{~Hz}, 1, \mathrm{H} 5^{\prime}\right), 6.20$ (d, $\left.J=1.9 \mathrm{~Hz}, 1, \mathrm{H} 1^{\prime}\right), 7.35$ (t, $J=$ $7.6 \mathrm{~Hz}, 4, \mathrm{Ph}), 7.46$ (t, $J=7.4 \mathrm{~Hz}, 2, \mathrm{Ph}), 7.85$ (d, $J=7.2 \mathrm{~Hz}, 4, \mathrm{Ph}), 8.16$ (s, 1, H2), 8.68 (s, 1, H8); ${ }^{13} \mathrm{C}$ NMR $\delta 25.7 \& 27.5\left(\mathrm{CMe}_{2}\right), 84.6\left(\mathrm{C}^{\prime}\right), 84.7\left(\mathrm{C}^{\prime}\right), 88.6\left(\mathrm{C}^{\prime}\right) 91.1\left(\mathrm{C} 1^{\prime}\right)$, $115.1\left(\mathrm{CMe}_{2}\right), 118.9\left(\mathrm{C}^{\prime}\right), 128.3(\mathrm{C} 5), 129.1(\mathrm{Ph}), 129.8(\mathrm{Ph}), 133.4(\mathrm{Ph}), 134.4(\mathrm{Ph})$, 
135.0 (C5'), 144.5 (C8), 152.4 (C4), 152.7 (C2), 152.8 (C6), 172.6 (CO); MS m/z 512 $\left(100, \mathrm{MH}^{+}\right)$. Anal. Calcd for $\mathrm{C}_{28} \mathrm{H}_{25} \mathrm{~N}_{5} \mathrm{O}_{5}(511.1856)$ : C, 65.74; H, 4.93. Found: $\mathrm{C}, 65.72$; $\mathrm{H}, 4.90$.

Ethyl 2-Aminohex-5-enoate (64). Step a. The 4-bromo-1-butene (1.7 mL, $2.27 \mathrm{~g}$, $16.8 \mathrm{mmol}$ ) was added to a heterogeneous mixture of $\mathrm{N}$-(diphenylmethylene)glycine ethyl ester 62 (3 g, $11.2 \mathrm{mmol})$, finely grounded $\mathrm{K}_{2} \mathrm{CO}_{3}(4.5 \mathrm{~g}, 32 \mathrm{mmol})$, and tetrabutylammonium bromide $(0.36 \mathrm{~g}, 1.12 \mathrm{mmol})$ in $\mathrm{CH}_{3} \mathrm{CN}(10 \mathrm{~mL})$ and the resulting mixture was refluxed with stirring (oil bath, $98{ }^{\circ} \mathrm{C}$ ). After $24 \mathrm{~h}$, the reaction mixture was cooled down to room temperature and was filtered. The filtrate was evaporated and the oily residue was partitioned $\left(\mathrm{H}_{2} \mathrm{O} / \mathrm{EtOAc}\right)$. The organic layer was dried $\left(\mathrm{Na}_{2} \mathrm{SO}_{4}\right)$, evaporated and column chromatographed (hexane/EtOAc, $85: 15)$ to give 63 (2.77 g, 77\%): ${ }^{1} \mathrm{H}$ NMR $\delta 1.30\left(\mathrm{t}, \mathrm{J}=7.0 \mathrm{~Hz}, 3, \mathrm{CH}_{3}\right), 1.98-2.13\left(\mathrm{~m}, 4, \mathrm{H} 3,3^{\prime}, 4,4^{\prime}\right), 4.08(\mathrm{t}, \mathrm{J}=6.1$ $\mathrm{Hz}, 1, \mathrm{H} 2), 4.21\left(\mathrm{q}, \mathrm{J}=7.0 \mathrm{~Hz}, 2, \mathrm{CH}_{2}\right), 4.92(\mathrm{dd}, \mathrm{J}=1.8,10.2 \mathrm{~Hz}, 1, \mathrm{H} 6), 4.98(\mathrm{dd}, \mathrm{J}=$ 1.8, 17.2 Hz, 1, H6'), 5.64-5.77 (m, 1, H5), 7.12-7.85 (m, 10, Ar); MS m/z $321(100$, $\left.\mathrm{MH}^{+}\right)$. Step $b .1 \mathrm{~N} \mathrm{HCl}(5.6 \mathrm{~mL}, 5.6 \mathrm{mmol})$ was added dropwise to a stirred solution of $63(2.0 \mathrm{~g}, 6.23 \mathrm{mmol})$ in $\mathrm{Et}_{2} \mathrm{O}(12 \mathrm{~mL})$ at $0 \mathrm{oC}$ (ice-bath). After $30 \mathrm{~min}$, the reaction mixture was allowed to warm-up to ambient temperature and stirring was continued for 5 h. The resulting two layers were separated, and the aqueous layer was neutralized with $\mathrm{NaHCO}_{3}$ to $\mathrm{pH} \sim 8$ and was then extracted with ether $(3 \times 15 \mathrm{~mL})$. The combined organic layer was evaporated to give $64^{127}(0.93 \mathrm{~g}, 95 \%)$ of sufficient purity for direct use in next step: ${ }^{1} \mathrm{H}$ NMR $\delta 1.25\left(\mathrm{t}, \mathrm{J}=7.1 \mathrm{~Hz}, 3, \mathrm{CH}_{3}\right), 1.52\left(\mathrm{br} \mathrm{s}, 2, \mathrm{NH}_{2}\right), 1.56-1.65\left(\mathrm{~m}, 1, \mathrm{H} 3{ }^{\prime}\right)$, 1.76-1.85 (m, 1, H3), 2.07-2.10 (m, 2, H4,4'), 3.39 (t, J = 7.7 Hz, 1, H2), 4.15 (q, J = 7.1 $\left.\mathrm{Hz}, 2, \mathrm{CH}_{2},\right), 4.97\left(\mathrm{dq}, \mathrm{J}=10.2,1.7 \mathrm{~Hz}, 1, \mathrm{H}^{\prime}\right), 5.04(\mathrm{dq}, \mathrm{J}=15.7,1.6 \mathrm{~Hz}, 1, \mathrm{H} 6), 5.73-$ 
$5.83(\mathrm{ddt}, \mathrm{J}=15.7,10.2,6.6 \mathrm{~Hz}, 1, \mathrm{H} 5) ;{ }^{13} \mathrm{C} \mathrm{NMR} \delta 14.6\left(\mathrm{CH}_{3}\right), 30.2(\mathrm{C} 4), 34.4(\mathrm{C} 3)$, $54.3(\mathrm{C} 2), 61.1\left(\mathrm{CH}_{2}\right), 115.6(\mathrm{C} 6), 137.9(\mathrm{C} 5), 176.4(\mathrm{C} 1) ; \mathrm{MS}$ m/z $158\left(100, \mathrm{MH}^{+}\right)$.

Ethyl 2- $N$-Benzoyl-2-aminohex-5-enoate (65). Benzoyl chloride $(0.82 \mathrm{~mL}, 992$ $\mathrm{mg}, 7.06 \mathrm{mmol}$ ) and DMAP (12 $\mathrm{mg}, 0.1 \mathrm{mmol}$ ) were added to a stirred solution of $\mathbf{6 4}$ (554 $\mathrm{mg}, 3.53 \mathrm{mmol})$ in pyridine $(5.5 \mathrm{~mL})$ at ambient temperature. The resulting mixture was stirred for $3 \mathrm{~h}$ at ambient temperature. Volatiles were evaporated and the residue was partitioned $\left(\mathrm{HCl} / \mathrm{H}_{2} \mathrm{O} / / \mathrm{CHCl}_{3}\right)$. The organic layer was washed $\left(\mathrm{NaHCO}_{3}\right.$, brine), dried $\left(\mathrm{MgSO}_{4}\right)$, evaporated and chromatographed $\left(\mathrm{CHCl}_{3}\right)$ to give $65(765 \mathrm{mg}, 84 \%)$ as a white solid: ${ }^{1} \mathrm{H}$ NMR $\delta 1.33\left(\mathrm{t}, J=7.1 \mathrm{~Hz}, 3, \mathrm{CH}_{3}\right), 1.89-1.95\left(\mathrm{~m}, 1, \mathrm{H} 3{ }^{\prime}\right), 2.15-2.23$ (m, 3, $\left.\mathrm{H} 3,4,4^{\prime}\right), 4.26\left(\mathrm{q}, J=7.1 \mathrm{~Hz}, 2, \mathrm{CH}_{2}\right), 4.87$ (ddd, $J=5.4,6.9,7.9 \mathrm{~Hz}, 1, \mathrm{H} 2$ ), 5.04 ( br d, $J$ $=10.2 \mathrm{~Hz}, 1, \mathrm{H} 6), 5.10$ (br d, $J=15.6 \mathrm{~Hz}, 1, \mathrm{H} 6$ '), 5.79-5.89 (m, 1, H5), 6.73 (br d, $J=$ $7.0 \mathrm{~Hz}, 1, \mathrm{NH}), 7.45$ (t, $J=7.5 \mathrm{~Hz}, 2, \mathrm{Ph}), 7.55$ (t, $J=7.2 \mathrm{~Hz}, 1, \mathrm{Ph}), 7.82$ (d, $J=7.0 \mathrm{~Hz}$, 2, Ph); ${ }^{13} \mathrm{C}$ NMR $\delta 14.5\left(\mathrm{CH}_{3}\right), 29.9(\mathrm{C} 4), 32.2(\mathrm{C} 3), 52.6(\mathrm{C} 2), 61.8\left(\mathrm{CH}_{2}\right), 116.0(\mathrm{C} 6)$, $127.4(\mathrm{Ph}), 128.9(\mathrm{Ph}), 132.1(\mathrm{Ph}), 134.4(\mathrm{Ph}), 137.5(\mathrm{C} 5), 167.4(\mathrm{CO}), 173.0(\mathrm{C} 1)$; MS $m / z 262\left(100, \mathrm{MH}^{+}\right)$. Anal. Calcd. for $\mathrm{C}_{15} \mathrm{H}_{19} \mathrm{NO}_{3}$ (261.32): C, 68.94; H, 7.33; N, 5.36. Found: C, 69.03; H, 7.46; N, 5.28.

Ethyl 2- $N$-(tert-Butoxycarbonylo)-2-aminohex-5-enoate (66). $\mathrm{NaHCO}_{3}(668$ $\mathrm{mg}, 7.95 \mathrm{mmol})$ and di-tert-butyl dicarbonate $(867 \mathrm{mg}, 3.98 \mathrm{mmol})$ were added to a stirred solution of $64(416 \mathrm{mg}, 2.65 \mathrm{mmol})$ in dioxane $/ \mathrm{H}_{2} \mathrm{O}(1: 1,8 \mathrm{~mL})$ at ambient temperature. After $18 \mathrm{~h}$, the reaction mixture was partitioned $\left(\mathrm{EtOAc} / \mathrm{H}_{2} \mathrm{O}\right)$ and the organic layer was washed (brine), dried $\left(\mathrm{Na}_{2} \mathrm{SO}_{4}\right)$ and evaporated. Column chromatography $\left(\mathrm{CHCl}_{3} \rightarrow 2 \% \mathrm{MeOH}\right)$ gave $66{ }^{113 \mathrm{c}, 128}(540 \mathrm{mg}, 79 \%):{ }^{1} \mathrm{H} \mathrm{NMR} \delta 1.28(\mathrm{t}$, $\left.J=7.1 \mathrm{~Hz}, 3, \mathrm{CH}_{3}\right), 1.44(\mathrm{~s}, 9, t-\mathrm{Bu}), 1.66-1.77(\mathrm{~m}, 1, \mathrm{H} 3 '), 1.85-1.96(\mathrm{~m}, 1, \mathrm{H} 3), 2.08-$ 
$2.16\left(\mathrm{~m}, 2, \mathrm{H} 4,4^{\prime}\right), 4.20\left(\mathrm{q}, J=7.1 \mathrm{~Hz}, 2, \mathrm{CH}_{2}\right), 4.25-4.35$ (m, 1, H2), 4.98 (br d, $J=10.2$ $\mathrm{Hz}, 1, \mathrm{H} 6), 5.02$ (br d, $J=15.6 \mathrm{~Hz}, 1, \mathrm{H} 6$ ), 5.04 (br, 1, NH), 5.76-5.80 (m, 1, H5); ${ }^{13} \mathrm{C}$ NMR $\delta 14.5\left(\mathrm{CH}_{3}\right), 28.7(t-\mathrm{Bu}), 29.8(\mathrm{C} 4), 32.4(\mathrm{C} 3), 53.4(\mathrm{C} 2), 61.6\left(\mathrm{CH}_{2}\right), 80.2(t-\mathrm{Bu})$, 115.9 (C6), 137.4 (C5), 155.7 (Boc), 173.1 (C1); MS m/z $258\left(20, \mathrm{MH}^{+}\right)$.

Ethyl 2- $N$-(tert-Butoxycarbonylo)-2-aminohex-5-enoate (66-R) and 2- $N-($ tertbutoxycarbonylo)-2-aminohex-5-enoic acid (74-S). Ester 66 (250 mg, $0.97 \mathrm{mmol})$ was suspended in phosphate buffer (15 mL, 0.1 M; pH 8.00) and $\alpha$-chymotrypsin (1.25 mg, 61 units/mg; Sigma) was added. The resulting mixture was gently stirred at $37{ }^{\circ} \mathrm{C}$ for 24 $\mathrm{h}(\mathrm{pH}$ decreased to 7.65$)$ and extracted with ethyl acetate. The combined organic layer was evaporated to give unreacted ester $66-R^{113 c, 128}(122 \mathrm{mg}, 49 \%)$ with data as reported above for 66. The aqueous solution was acidified to $\mathrm{pH} 2.5$ with $1 \mathrm{~N} \mathrm{HCl}$ and extracted with ethyl acetate $(5 \times)$. The combined organic layer was dried $\left(\mathrm{Na}_{2} \mathrm{SO}_{4}\right)$ and evaporated to give $74-S^{112}(109 \mathrm{mg}, 49 \%):{ }^{1} \mathrm{H}$ NMR $\delta 1.46(\mathrm{~s}, 9, t-\mathrm{Bu}), 1.70-1.85(\mathrm{~m}, 1, \mathrm{H} 3), 1.90-$ 2.05 (m, 1, H3'), 2.10-2.22 (m, 2, H4,4'), 4.32-4.42 (m, 1, H2), 5.00 (br d, $J=10.0 \mathrm{~Hz}, 1$, H6), 5.07 (br s, 1, NH), 5.10 (br d, $J=16.1 \mathrm{~Hz}, 1, \mathrm{H6}$ '), 5.76-5.86 (m, 1, H5), 9.06 (br s, 1, $\mathrm{COOH}) ; \mathrm{MS} m / z 230\left(100, \mathrm{MH}^{+}\right)$.

Notes. The enantiomeric purity of $66-R$ was determined using Mosher test with (R)-2-methoxy-2-trifluoromethyl-2-phenylacetyl chloride $\quad(R-\mathrm{MTPA}-\mathrm{Cl}):^{119}$ Step $\quad a$ (Deprotection). Treatment of 66- $R(30 \mathrm{mg}, 0.11 \mathrm{mmol})$ with $\mathrm{CF}_{3} \mathrm{CO}_{2} \mathrm{H} / \mathrm{H}_{2} \mathrm{O}(9: 1,2 \mathrm{~mL})$ by procedure $\mathrm{C}$ [column chromatography $\left.\left(\mathrm{CHCl}_{3} / \mathrm{MeOH}, 95: 5\right)\right]$ gave $64-R$ (16 mg, 90\%). Step b (Acylation). DMAP (0.46 mg, $0.0038 \mathrm{mmol})$ and (R)-MTPA-Cl (57.5 mg, $0.22 \mathrm{mmol})$ was added to a stirred solution of $64-R(30 \mathrm{mg}, 0.19 \mathrm{mmol})$ in pyridine/benzene $(3 \mathrm{~mL}, 1: 2)$ at ambient temperature. After $2 \mathrm{~h}$, volatiles were 
evaporated and the residue was partitioned $\left(\mathrm{NaHCO}_{3} / \mathrm{H}_{2} \mathrm{O} / / \mathrm{EtOAc}\right)$. The separated organic layer was washed (brine), dried $\left(\mathrm{Na}_{2} \mathrm{SO}_{4}\right)$, evaporated, and chromatographed (0 $\rightarrow 15 \%$ EtOAc/hexane) to give $76-R / R(53 \mathrm{mg}, 73 \%$; ee 96$):{ }^{19} \mathrm{~F}$ NMR $\delta-69.55(\mathrm{~s}, R / R$, $0.98 \mathrm{~F})$ and $-69.15(\mathrm{~s}, S / R, 0.02 \mathrm{~F})$.

Subjection of racemic $66-R / S$ to the analogous sequence with $(R)$-MTPA-Cl gave $1: 1\left({ }^{19} \mathrm{~F}\right.$ NMR) mixture of 76-R/R and its diastereomer 76-S/R.

\section{Ethyl $\quad 1,5,6,7,8,9-H e x a d e o x y-9(R / S)$-benzamido-1-(6- $N$-benzoyladenin-9-yl)-} 2,3-O-isopropylidene- $\beta$-D-ribo-dec-5(E)-enofuranuronate $\quad(67 \mathrm{~b})$. Procedure A. Compounds 61a (100 mg, $0.25 \mathrm{mmol}), 65(65 \mathrm{mg}, 0.25 \mathrm{mmol})$ and $1,3-[\mathrm{bis}(2,4,6-$ trimethylphenyl)-2-imidazolidinylidene]dichloro (isopropoxyphenylmethylene)ruthenium (7.8 $\mathrm{mg}, 0.0125 \mathrm{mmol}$ ) were dissolved in dried $\mathrm{CH}_{2} \mathrm{Cl}_{2}(6 \mathrm{~mL})$ at ambient temperature under $\mathrm{N}_{2}$ and the resulting mixture was heated overnight at $65^{\circ} \mathrm{C}$ (oil bath) in a pressure tube (Ace glass). Volatiles were evaporated and the residue was partitioned $\left(\mathrm{NaHCO}_{3} / / \mathrm{H}_{2} \mathrm{O} / \mathrm{CHCl}_{3}\right)$. The organic layer was washed (brine), dried $\left(\mathrm{Na}_{2} \mathrm{SO}_{4}\right)$, evaporated, and chromatographed $(50 \rightarrow 90 \%$ EtOAc/hexane) to give $67 \mathbf{b}(82 \mathrm{mg}, 51 \%$, $\left.9^{\prime} R / S \sim 1: 1\right)$ and dimer $73(14 \mathrm{mg}, 11 \%)$ as a less polar byproduct. 67b: ${ }^{1} \mathrm{H}$ NMR $\delta 1.12$ ("dt", $\left.J=2.5,7.1 \mathrm{~Hz}, 3, \mathrm{CH}_{3}\right), 1.25\left(\mathrm{~s}, 3, \mathrm{CH}_{3}\right), 1.48\left(\mathrm{~s}, 3, \mathrm{CH}_{3}\right), 1.52-2.02\left(\mathrm{~m}, 4 \mathrm{H}, 7^{\prime}, 7 "\right.$, 8',8"), 4.06 ("dq", $\left.J=3.0,7.1 \mathrm{~Hz}, 2, \mathrm{CH}_{2}\right), 4.54$ ("dt", $J=2.9,7.4 \mathrm{~Hz}, 1, \mathrm{H} 4$ '), $4.62(\mathrm{t}, J=$ $\left.7.4 \mathrm{~Hz}, 0.5, \mathrm{H} 9^{\prime}\right), 4.63\left(\mathrm{t}, J=7.4 \mathrm{~Hz}, 0.5, \mathrm{H} 9^{\prime}\right), 4.81-4.86\left(\mathrm{~m}, 1, \mathrm{H} 3^{\prime}\right), 5.39-5.43(\mathrm{~m}, 1$, H2'), 5.43 (dd, $\left.J=7.1,16.2 \mathrm{~Hz}, 1, \mathrm{H} 5^{\prime}\right), 5.56$ ("dt", $\left.J=7.3,16.4 \mathrm{~Hz}, 1, \mathrm{H} 6{ }^{\prime}\right), 6.00$ (s, 1, H1'), 6.59 ("t", $J=7.2 \mathrm{~Hz}, 1, \mathrm{NH})$, 7.24-7.30 (m, 2, Ph), 7.32-7.40 (m, 3, Ph), 7.43-7.49 (m, 1, Ph), 7.62-7.67 (m, 2, Ph), 7.87-7.90 (m, 2, Ph), 7.96 (s, 0.5, H2), 7.97 (s, 0.5, H2), $8.66(\mathrm{~s}, 0.5, \mathrm{H} 8), 8.67$ (s, 0.5, H8), 9.00 (br s, $1, \mathrm{NH}) ;{ }^{13} \mathrm{C}$ NMR $\delta 14.2\left(\mathrm{CH}_{3}\right), 25.4$ 
$\left(\mathrm{CH}_{3}\right), 27.1\left(\mathrm{CH}_{3}\right), 28.0\left(\mathrm{C}^{\prime}\right) 31.66 \& 31.75\left(\mathrm{C}^{\prime}\right), 52.01 \& 52.13\left(\mathrm{C}^{\prime}\right), 61.7\left(\mathrm{CH}_{2}\right)$, $84.2\left(\mathrm{C} 2^{\prime}\right), 84.49 \& 84.54\left(\mathrm{C}^{\prime}\right), 88.04 \& 88.09\left(\mathrm{C}^{\prime}\right), 90.78 \& 90.85\left(\mathrm{Cl}^{\prime}\right), 114.5\left(\mathrm{CMe}_{2}\right)$, $123.64 \& 123.70\left(\mathrm{C}^{\prime}\right), 127.0(\mathrm{Ph}), 127.7(\mathrm{C} 5), 127.9(\mathrm{Ph}), 128.6(\mathrm{Ph}), 128.8(\mathrm{Ph}), 131.8$ (Ph), $132.8(\mathrm{Ph}), 133.5\left(\mathrm{C}^{\prime}\right), 133.84$ (C4), 133.94 (C6), 142.27 \& 142.32 (C2), 151.4(C8), $167.0(\mathrm{Bz}), 172.34(\mathrm{Bz}), 172.38\left(\mathrm{C} 10^{\prime}\right)$; MS m/z $641\left(100 \%, \mathrm{MH}^{+}\right)$. HRMS calcd. for $\mathrm{C}_{34} \mathrm{H}_{36} \mathrm{~N}_{6} \mathrm{O}_{7}\left(\mathrm{M}+\mathrm{Li}^{+}\right)$647.2806, found 647.2809.

Dimer 73 [Diethyl 2,9-bis(benzamido)dec-5-enedioate] separated as a mixture of two isomers ( 9:1). The major isomer had: ${ }^{1} \mathrm{H}$ NMR $\delta 1.22(" \mathrm{dt} ", J=1.2,7.1 \mathrm{~Hz}, 6,2 \mathrm{x}$ $\left.\mathrm{CH}_{3}\right), 1.70-1.85(\mathrm{~m}, 2, \mathrm{H} 3 / 8), 1.90-2.15\left(\mathrm{~m}, 6, \mathrm{H}^{\prime}, 4,4^{\prime} / 7,7^{\prime}, 8^{\prime}\right), 4.16(\mathrm{q}, J=7.0 \mathrm{~Hz}, 4,2 \mathrm{x}$ $\mathrm{CH}_{2}$ ), 4.67-4.76 (m, 2, H2/9), 5.40 ("t", $\left.J=3.4 \mathrm{~Hz}, 2, \mathrm{H} 5 / 6\right), 6.62$ (d, $J=7.6 \mathrm{~Hz}, 2,2 \mathrm{x}$ $\mathrm{NH})$, 7.35-7.44 (m, 6, Ph), 7.71-7.73 (m, 4, Ph); ${ }^{13} \mathrm{CNMR} \delta 14.6\left(\mathrm{CH}_{3}\right), 28.8(\mathrm{C} 4 / 7), 32.7$ (C3/8), $52.6(\mathrm{C} 2 / 9), 61.9\left(\mathrm{CH}_{2}\right), 127.4(\mathrm{Ph}), 128.9(\mathrm{C} 5 / 6), 130.3(\mathrm{Ph}), 132.1(\mathrm{Ph}), 134.4$ (Ph), $167.3(\mathrm{CO}), 172.9(\mathrm{C} 1 / 10)$; MS m/z $495\left(100 \%, \mathrm{MH}^{+}\right)$. HRMS calcd for $\mathrm{C}_{28} \mathrm{H}_{34} \mathrm{~N}_{2} \mathrm{O}_{6}\left(\mathrm{M}+\mathrm{Li}^{+}\right)$501.2577, found 501.2573.

Ethyl $1,5,6,7,8,9-$ Hexadeoxy-9(R/S)-benzamido-1-(6- $N, N$-dibenzoyladenin-9yl)-2,3-O-isopropylidene- $\beta$-D-ribo-dec-5(E)-enofuranuronate (67c). Treatment of $61 \mathrm{~b}$ (92 $\mathrm{mg}, 0.18 \mathrm{mmol})$ with $65(47 \mathrm{mg}, 0.18 \mathrm{mmol})$ by procedure A [column chromatography $\left(30 \rightarrow 50 \%\right.$ EtOAc/hexanes)] gave 67c $\left(80 \mathrm{mg}, 60 \%, 9^{\prime} R / S \sim 1: 1\right)$ and $73(16 \mathrm{mg}, 18 \%) .67 \mathrm{c}:{ }^{1} \mathrm{H}$ NMR $\delta 1.20\left(\mathrm{t}, J=7.2 \mathrm{~Hz}, 3, \mathrm{CH}_{3}\right), 1.32\left(\mathrm{~s}, 3, \mathrm{CH}_{3}\right), 1.53(\mathrm{~s}, 3$, $\mathrm{CH}_{3}$ ), 1.54-1.69 (m, 2, H8', 8"), 1.81-2.10 (m, 2, H7',7"), 4.14 (q, J= 7.1 Hz, 2, $\mathrm{CH}_{2}$ ), 4.63 ("dt", $J=3.1,7.0 \mathrm{~Hz}, 1, \mathrm{H} 4$ '), 4.69 (t, $J=7.6 \mathrm{~Hz}, 0.5, \mathrm{H} 9$ '), 4.70 (t, $J=7.6 \mathrm{~Hz}, 0.5, \mathrm{H} 9$ '), 4.88 ("dt", $J=3.2,6.3 \mathrm{~Hz}, 1, \mathrm{H} 3$ '), 5.42-5.49 (m, 1, H2'), 5.50 (dd, $J=7.2,15.9 \mathrm{~Hz}, 1$, H5'), 5.59-5.68 (m, 1, H6'), 6.06 (s, 1, H1'), 6.70 ("t", $J=6.2 \mathrm{~Hz}, 1, \mathrm{NH}), 7.25-7.45$ (m, 9 , 
$\mathrm{Ph}), 7.68-7.80(\mathrm{~m}, 6, \mathrm{Ph}), 8.08$ (s, 0.5, H2), 8.09 (s, 0.5, H2), 8.58 (s, 0.5, H8), 8.61 (s, $0.5, \mathrm{H} 8) ;{ }^{13} \mathrm{CNMR} \delta 14.2\left(\mathrm{CH}_{3}\right), 25.3\left(\mathrm{CH}_{3}\right), 27.0\left(\mathrm{CH}_{3}\right), 28.2\left(\mathrm{C}^{\prime}\right), 31.7 \& 31.9\left(\mathrm{C} 8^{\prime}\right)$, $52.09 \& 52.20\left(\mathrm{C}^{\prime}\right), 61.6\left(\mathrm{CH}_{2}\right), 84.1\left(\mathrm{C}^{\prime}\right), 84.4\left(\mathrm{C}^{\prime}\right), 87.8 \& 87.9\left(\mathrm{C}^{\prime}\right), 90.8\left(\mathrm{C}^{\prime}\right)$, 114.6 $\left(\mathrm{CMe}_{2}\right), 127.1\left(\mathrm{C}^{\prime}\right), 128.6(\mathrm{Ph}), 128.7(\mathrm{Ph}), 128.8(\mathrm{C} 5), 129.5(\mathrm{Ph}), 131.7(\mathrm{Ph})$, $133.0(\mathrm{Ph}), 134.0\left(\mathrm{C} 6{ }^{\prime}\right), 152.0(\mathrm{C} 4), 152.3(\mathrm{C} 2), 152.5(\mathrm{C} 6), 167.10,167.13,172,28(\mathrm{Bz})$, $172.32\left(\mathrm{C}^{\prime}\right)$; $\mathrm{MS} m / z 745\left(100 \%, \mathrm{MH}^{+}\right)$. HRMS calcd for $\mathrm{C}_{41} \mathrm{H}_{40} \mathrm{~N}_{6} \mathrm{O}_{8}\left(\mathrm{M}+\mathrm{H}^{+}\right)$ 745.2986, found 745.2990 .

Ethyl 1,5,6,7,8,9-Hexadeoxy-9(R/S)-tert-butoxycarbonylamino-1-(6- $N$ -

benzoyladenin-9-yl)-2,3- $O$-isopropylidene- $\beta$-D-ribo-dec-5(E)-enofuranuronate $(68 \mathrm{~b})$.

Treatment of $61 \mathrm{a}(36 \mathrm{mg}, 0.09 \mathrm{mmol})$ with $66(23 \mathrm{mg}, 0.09 \mathrm{mmol})$ by procedure A [column chromatography $\left(20 \rightarrow 50 \%\right.$ EtOAc/hexanes)] gave $68 \mathbf{b}\left(35 \mathrm{mg}, 61 \%, 9^{\prime} R / S \sim\right.$ 1:1): ${ }^{1} \mathrm{H}$ NMR $\delta 1.18\left(\mathrm{t}, J=6.9 \mathrm{~Hz}, 3, \mathrm{CH}_{3}\right), 1.34\left(\mathrm{~s}, 3, \mathrm{CH}_{3}\right), 1.35(\mathrm{~s}, 9, \mathrm{Boc}), 1.46-1.53$ (m, 1, H8"), 1.56 (s, 3, CH $), 1.68-1.78$ (m, 1, H8'), 1.92-2.03 (m, 2, H7',7"), 4.10 ("dq", $J$ $\left.\left.=2,2,7.1 \mathrm{~Hz}, \mathrm{CH}_{2}\right), 4.15-4.20(\mathrm{~m}, 1, \mathrm{H} 9)^{\prime}\right), 4.60-4.65\left(\mathrm{~m}, 1, \mathrm{H} 4{ }^{\prime}\right), 4.92(\mathrm{dd}, J=3.3,6.2$ $\left.\mathrm{Hz}, 1, \mathrm{H}^{\prime}\right), 4.95-5.00(\mathrm{~m}, 1, \mathrm{NH}), 5.48\left(\mathrm{br} \mathrm{d}, J=7.7 \mathrm{~Hz}, 1, \mathrm{H} 2^{\prime}\right), 5.50(\mathrm{dd}, J=7.2,16.1$ $\left.\mathrm{Hz}, 1, \mathrm{H} 5^{\prime}\right), 5.62\left(\mathrm{dt}, J=6.7,15.9 \mathrm{~Hz}, 1, \mathrm{H} 6^{\prime}\right), 6.08\left(\mathrm{br} \mathrm{s}, 1, \mathrm{H} 1^{\prime}\right), 7.45$ (t, $J=7.2 \mathrm{~Hz}, 2$, $\mathrm{Ph}), 7.54$ (t, $J=7.3 \mathrm{~Hz}, 1, \mathrm{Ph}), 7.95$ (d, $J=7.4 \mathrm{~Hz}, 2, \mathrm{Ph}), 8.04$ (br s, 1, H2), 8.76 (s, 0.5, H8), 8.77 (s, 0.5, H8), 9.03 (br s, 1, NH); MS m/z $637\left(100 \%, \mathrm{MH}^{+}\right)$. HRMS calcd. for $\mathrm{C}_{32} \mathrm{H}_{40} \mathrm{~N}_{6} \mathrm{O}_{8}\left(\mathrm{M}+\mathrm{Li}^{+}\right)$643.3068, found 643.3076. Anal. Calcd. for $\mathrm{C}_{32} \mathrm{H}_{40}-\mathrm{N}_{6} \mathrm{O}_{8}(636.29)$ : C, 60.37; H, 6.33; N, 13.20. Found: C, 60.02; H, 6.54; N, 12.88 .

Ethyl $\quad 1,5,6,7,8,9-$ Hexadeoxy-9 $(R / S)$-tert-butoxycarbonylamino-1-(6- $N, N$ dibenzoyladenin-9-yl)-2,3- $O$-isopropylidene- $\beta$-D-ribo-dec-5(E)-enofuranuronate $(68 \mathrm{c}-\boldsymbol{R} / \boldsymbol{S})$. Treatment of $\mathbf{6 1 \mathrm { b }}(200 \mathrm{mg}, 0.4 \mathrm{mmol})$ with $66(103 \mathrm{mg}, 0.4 \mathrm{mmol})$ by 
procedure A [column chromatography $(30 \rightarrow 50 \%$ EtOAc/hexanes)] gave $68 \mathrm{c}-R / S(224$ $\left.\mathrm{mg}, 76 \%, 9^{\prime} R / S \sim 1: 1\right):$ UV $\max 270 \mathrm{~nm}(\varepsilon 15000, \mathrm{sh}), 250 \mathrm{~nm}(\varepsilon 19000), \min 227 \mathrm{~nm}$ ( $\varepsilon 12800) ;{ }^{1} \mathrm{H}$ NMR $\delta 1.23\left(\mathrm{t}, J=7.1 \mathrm{~Hz}, 3, \mathrm{CH}_{3}\right), 1.39\left(\mathrm{~s}, 3, \mathrm{CH}_{3}\right), 1.42(\mathrm{~s}, 9, \mathrm{Boc}), 1.61$ (s, 3, $\left.\mathrm{CH}_{3}\right), 1.58-1.65$ (m, 1, H8'), 1.78-1.84 (m, 1, H8"), 2.00-2.09 (m, 2, H7',7"), 4.15 (q, $\left.J=7.1 \mathrm{~Hz}, 2, \mathrm{CH}_{2}\right), 4.20-4.28\left(\mathrm{~m}, 1, \mathrm{H}^{\prime}\right), 4.62-4.69$ (m, 1, H4'), 4.95 (dd, $J=3.6,6.2$ $\left.\mathrm{Hz}, 1, \mathrm{H} 3^{\prime}\right), 5.07$ ("t", $\left.J=8.5 \mathrm{~Hz}, 1, \mathrm{NH}\right), 5.43-5.50$ (m, 1, H2'), 5.58 (dd, $J=7.3,15.2$ $\left.\mathrm{Hz}, 1, \mathrm{H}^{\prime}\right), 5.73\left(\mathrm{dt}, J=6.5,15.2 \mathrm{~Hz}, 1, \mathrm{H} 6^{\prime}\right), 6.120\left(\mathrm{~d}, J=2.1 \mathrm{~Hz}, 0.5, \mathrm{H} 1^{\prime}\right), 6.122(\mathrm{~d}, J$ $\left.=2.1 \mathrm{~Hz}, 0.5, \mathrm{H1}{ }^{\prime}\right), 7.35(\mathrm{t}, J=7.6 \mathrm{~Hz}, 4, \mathrm{Ph}), 7.49(\mathrm{t}, J=7.4 \mathrm{~Hz}, 2, \mathrm{Ph}), 7.85(\mathrm{~d}, J=7.1$ $\mathrm{Hz}, 4, \mathrm{Ph}), 8.147$ (s, 0.5, H2), 8.149 (s, 0.5, H2), 8.68 (s, 1, H8); ${ }^{13} \mathrm{C}$ NMR $\delta 14.2\left(\mathrm{CH}_{3}\right)$, $25.3\left(\mathrm{CH}_{3}\right), 27.1\left(\mathrm{CH}_{3}\right), 28.0\left(\mathrm{C}^{\prime}\right), 28.3$ (Boc), $31.76 \& 31.80\left(\mathrm{C} 8^{\prime}\right), 52.9\left(\mathrm{C}^{\prime}\right), 61.3$ $\left(\mathrm{CH}_{2}\right), 80.2(\mathrm{Boc}), 84.16 \& 84.19\left(\mathrm{C}^{\prime}\right), 84.33 \& 84.37\left(\mathrm{C} 3^{\prime}\right), 87.83 \& 87.91\left(\mathrm{C} 4^{\prime}\right), 90.58$ \& $90.67\left(\mathrm{Cl}^{\prime}\right), 114.7\left(\mathrm{CMe}_{2}\right), 127.47 \& 127.51\left(\mathrm{C}^{\prime}\right), 128.0(\mathrm{C} 5), 128.7(\mathrm{Ph}), 129.4(\mathrm{Ph})$, $133.0(\mathrm{Ph}), 134.0(\mathrm{Ph}), 134.30 \& 134.31\left(\mathrm{C} 6{ }^{\prime}\right), 144.0(\mathrm{C} 8), 152.0(\mathrm{C} 4), 152.3(\mathrm{C} 2), 152.4$ (C6), 155.3 (Boc), $172.2(\mathrm{Bz}), 172.50 \& 172.57\left(\mathrm{C} 10^{\prime}\right) ; \mathrm{MS} m / z 741\left(100 \%, \mathrm{MH}^{+}\right)$. HRMS $\left(\mathrm{FAB}^{+}\right)$calcd for $\mathrm{C}_{39} \mathrm{H}_{44} \mathrm{~N}_{6} \mathrm{O}_{9}\left(\mathrm{M}+\mathrm{H}^{+}\right) 741.3248$, found 741.3243 .

Ethyl $\quad 1,5,6,7,8,9-H e x a d e o x y-9(R)$-tert-butoxycarbonylamino-1-(6- $N, N$ dibenzoyladenin-9-yl)-2,3-O-isopropylidene- $\beta$-D-ribo-dec-5(E)-enofuranuronate $(68 \mathrm{c}-R)$. Metathesis of $61 \mathrm{~b}(25 \mathrm{mg}, 0.05 \mathrm{mmol})$ with $66-R(13 \mathrm{mg}, 0.05 \mathrm{mmol})$ by procedure A [column chromatography $(30 \rightarrow 50 \%$ EtOAc/hexanes)] gave 68c- $R(28.5$ mg, 77\%): ' ${ }^{1} \mathrm{H}$ NMR $\delta 1.23\left(\mathrm{t}, J=7.1 \mathrm{~Hz}, 3, \mathrm{CH}_{3}\right), 1.39\left(\mathrm{~s}, 3, \mathrm{CH}_{3}\right), 1.42$ (s, 9, Boc), $1.61\left(\mathrm{~s}, 3, \mathrm{CH}_{3}\right), 1.58-1.65$ (m, 1, H8'), 1.78-1.84 (m, 1, H8"), 2.00-2.09 (m, 2, H7',7"), $4.15\left(\mathrm{q}, J=7.1 \mathrm{~Hz}, 2, \mathrm{CH}_{2}\right), 4.20-4.28\left(\mathrm{~m}, 1, \mathrm{H} 9^{\prime}\right), 4.66\left(\mathrm{dd}, J=3.4,7.3 \mathrm{~Hz}, 1, \mathrm{H} 4^{\prime}\right)$, 4.95 (dd, $\left.J=3.6,6.2 \mathrm{~Hz}, 1, \mathrm{H} 3^{\prime}\right), 5.05(\mathrm{br} \mathrm{d}, J=8.4 \mathrm{~Hz}, 1, \mathrm{NH}), 5.47$ (dd, $J=2.2,6.3 \mathrm{~Hz}$, 
1, H2'), $5.58\left(\mathrm{dd}, J=7.3,15.1 \mathrm{~Hz}, 1, \mathrm{H} 5^{\prime}\right), 5.73\left(\mathrm{dt}, J=6.5,15.3 \mathrm{~Hz}, 1, \mathrm{H} 6^{\prime}\right), 6.12(\mathrm{~d}, J=$ $\left.2.1 \mathrm{~Hz}, 1, \mathrm{H1} 1^{\prime}\right), 7.35$ (t, $\left.J=7.6 \mathrm{~Hz}, 4, \mathrm{Ph}\right), 7.49(\mathrm{t}, J=7.4 \mathrm{~Hz}, 2, \mathrm{Ph}), 7.85(\mathrm{~d}, J=7.1 \mathrm{~Hz}$, 4, Ph), 8.14 (s, 1, H2), $8.68(\mathrm{~s}, 1, \mathrm{H} 8) ;{ }^{13} \mathrm{C}$ NMR $\delta 14.2\left(\mathrm{CH}_{3}\right), 25.3\left(\mathrm{CH}_{3}\right), 27.1\left(\mathrm{CH}_{3}\right)$, $28.0\left(\mathrm{C}^{\prime}\right), 28.3(\mathrm{Boc}), 31.80\left(\mathrm{C}^{\prime}\right), 52.9\left(\mathrm{C}^{\prime}\right), 61.3\left(\mathrm{CH}_{2}\right), 80.2(\mathrm{Boc}), 84.19\left(\mathrm{C}^{\prime}\right), 84.37$ (C3'), 87.91 (C4'), $90.67\left(\mathrm{Cl}^{\prime}\right), 114.7\left(\mathrm{CMe}_{2}\right), 127.51\left(\mathrm{C}^{\prime}\right), 128.0(\mathrm{C} 5), 128.7(\mathrm{Ph}), 129.4$ (Ph), $133.0(\mathrm{Ph}), 134.0(\mathrm{Ph}), 134.31$ (C6') 144.0 (C8), 152.0 (C4), 152.3 (C2), 152.4 (C6), 155.3 (Boc), 172.2 (Bz), $172.57\left(\mathrm{C} 10^{\prime}\right)$; MS m/z 741 (100\%, $\left.\mathrm{MH}^{+}\right)$. HRMS (FAB ${ }^{+}$) calcd for $\mathrm{C}_{39} \mathrm{H}_{44} \mathrm{~N}_{6} \mathrm{O}_{9}\left(\mathrm{M}+\mathrm{H}^{+}\right) 741.3248$, found 741.3246.

\section{Methyl 2-N-(tert-Butoxycarbonylo)-2-aminohex-5-enoate}

$(75-S)$.

Diazomethane $^{129}$ was added to a solution of $\mathbf{7 4 - S}(120 \mathrm{mg}, 0.52 \mathrm{mmol})$ in EtOH $(2 \mathrm{~mL})$ at ambient temperature. After 30 min (reaction was monitored by LC/MS), the volatiles were evaporated to give $75-S^{112}(118 \mathrm{mg}, 93 \%)$ as an oily residue: ${ }^{1} \mathrm{H}$ NMR $\delta 1.37(\mathrm{~s}, 9$, $t$-Bu), 1.59-1.69 (m, 1, H3), 1.78-1.91 (m, 1, H3'), 2.00-2.10 (m, 2, H4,4'), 3.67 (s, 3, $\mathrm{OCH}_{3}$ ), 4.22 ("q", $J=7.9 \mathrm{~Hz}, 1, \mathrm{H} 2$ ), 4.93 ( br d, $J=10.2,1, \mathrm{H6}$ '), 4.97 (dq, $J=17.1,1.5$ $\mathrm{Hz}, 1, \mathrm{H} 6), 4.99$ (br s, 1, NH), 5.83 (ddt, $J=17.0,10.2,6.7 \mathrm{~Hz}, 1, \mathrm{H} 5),{ }^{13} \mathrm{C}$ NMR $\delta 27.3$ (Boc), $28.4(\mathrm{C} 4), 30.9(\mathrm{C} 3), 51.2\left(\mathrm{OCH}_{3}\right), 51.9(\mathrm{C} 2), 78.8$ (Boc), $114.6(\mathrm{C} 6), 135.9(\mathrm{C} 5)$, $154.3(\mathrm{CO}), 172.3(\mathrm{C} 1)$; MS $m / z 244\left(100 \% \mathrm{MH}^{+}\right)$.

Methyl $\quad 1,5,6,7,8,9-$ Hexadeoxy-9(S)-tert-butoxycarbonylamino-1-(6- $N, N$ dibenzoyladenin-9-yl)-2,3-O-isopropylidene- $\beta$-D-ribo-dec-5(E)-enofuranuronate (77S). Metathesis of $\mathbf{6 1 b}(200 \mathrm{mg}, 0.39 \mathrm{mmol})$ with $75-S(95 \mathrm{mg}, 0.39 \mathrm{mmol})$ by procedure A [column chromatography $(30 \rightarrow 50 \%$ EtOAc/hexanes $)]$ gave $77-S(218 \mathrm{mg}, 77 \%):{ }^{1} \mathrm{H}$ NMR $\delta 1.40\left(\mathrm{~s}, 3, \mathrm{CH}_{3}\right), 1.44\left(\mathrm{~s}, 9, t\right.$-Bu), $1.61\left(\mathrm{~s}, 3, \mathrm{CH}_{3}\right), 1.56-1.63(\mathrm{~m}, 1, \mathrm{H} 8 "), 1.75-$ 1.86 (m, 1, H8'), 2.00-2.11 (m, 2, H7',7"), 3.71 (s, 3, OMe), 4.27 ("q", J=6.7 Hz, 1, H9'), 
$4.67\left(\mathrm{dd}, J=6.8,3.1 \mathrm{~Hz}, 1, \mathrm{H} 4^{\prime}\right), 4.95\left(\mathrm{dd}, J=6.2,3.5 \mathrm{~Hz}, 1, \mathrm{H} 3^{\prime}\right), 5.11$ (br d, $J=8.4 \mathrm{~Hz}$, 1, NH), 5.50 (dd, $\left.J=6.4,2.0 \mathrm{~Hz}, 1, \mathrm{H} 2^{\prime}\right), 5.54$ (dd, $\left.J=15.3,7.2 \mathrm{~Hz}, 1, \mathrm{H} 5^{\prime}\right), 5.68$ (dt, $J=$ 15.0, 6.4 Hz, 1, H6'), 6.15 (d, $\left.J=1.9 \mathrm{~Hz}, 1, \mathrm{H} 1^{\prime}\right), 7.35$ (t, $\left.J=7.9 \mathrm{~Hz}, 4, \mathrm{Ph}\right), 7.48$ (t, $J=$ $7.4 \mathrm{~Hz}, 2, \mathrm{Ph}), 7.85$ (d, $J=7.1 \mathrm{~Hz}, 4, \mathrm{Ph}), 8.17$ (s, 1, H2), 8.69 (s, 1, H8); ${ }^{13} \mathrm{C}$ NMR $\delta$ $25.3\left(\mathrm{CH}_{3}\right), 27.1\left(\mathrm{CH}_{3}\right), 27.9\left(\mathrm{C}^{\prime}\right), 28.3$ (Boc), 31.7 (C8'), 52.3 (OMe), 52.9 (C9'), 79.9 (Boc), 84.1 (C2'), $84.3\left(\mathrm{C}^{\prime}\right), 87.8\left(\mathrm{C}^{\prime}\right), 90.5\left(\mathrm{Cl}^{\prime}\right), 114.7\left(\mathrm{CMe}_{2}\right), 127.5\left(\mathrm{C} 5^{\prime}\right), 128.0$ (C5), $128.7(\mathrm{Ph}), 129.4(\mathrm{Ph}), 133.0(\mathrm{Ph}), 133.9(\mathrm{Ph}), 134.1$ (C6'), 144.1 (C8), $152.0(\mathrm{C} 4)$, 152.3 (C2), 152.4 (C6), 155.3 (Boc), 172.2 (CO), 172.9 (C10'); MS m/z 727 (100\%, $\mathrm{MH}^{+}$). HRMS calcd for $\mathrm{C}_{38} \mathrm{H}_{42} \mathrm{~N}_{6} \mathrm{O}_{9}\left(\mathrm{M}+\mathrm{H}^{+}\right)$727.3092, found 727.3099.

\section{Methyl 1,5,6,7,8,9-Hexadeoxy-9(S)-tert-butoxycarbonylamino-1-(adenin-9-}

yl)-2,3-O- isopropylidene- $\beta$-D-ribo-dec-5(E)-enofuranuronate (69-S). Procedure B:

Saturated $\left(\sim 0{ }^{\circ} \mathrm{C}\right) \mathrm{NH}_{3} / \mathrm{MeOH}(3 \mathrm{~mL})$ was added to a solution of $77-S(210 \mathrm{mg}, 0.29$ mmol) in $\mathrm{MeOH}(3 \mathrm{~mL})$ at $5{ }^{\circ} \mathrm{C}$, and the resulting mixture was stirred for $48 \mathrm{~h}$ at $0{ }^{\circ} \mathrm{C}$. Volatiles were evaporated and the residue was column chromatographed $(50 \rightarrow 95 \%$ EtOAc/hexanes) to give 69-S (136 mg, 91\%): ${ }^{1} \mathrm{H}$ NMR $\delta 1.35\left(\mathrm{~s}, 3, \mathrm{CH}_{3}\right), 1.37(\mathrm{~s}, 9$, Boc), $1.55\left(\mathrm{~s}, 3, \mathrm{CH}_{3}\right), 1.52-1.60(\mathrm{~m}, 1, \mathrm{H} 8 "), 1.69-1.80(\mathrm{~m}, 1, \mathrm{H} 8$ '), 1.90-2.00 (m, 2, H7',7"), 3.65 (s, 3, OMe), 4.20 ("q", $\left.J=7.0 \mathrm{~Hz}, 1, \mathrm{H} 9^{\prime}\right), 4.56$ (dd, $J=3.4,7.1 \mathrm{~Hz}, 1, \mathrm{H} 4$ '), $4.89\left(\mathrm{dd}, J=3.4,6.1 \mathrm{~Hz}, 1, \mathrm{H}^{\prime}\right), 5.05(\mathrm{br} \mathrm{d}, J=8.1 \mathrm{~Hz}, 1, \mathrm{NH}), 5.44(\mathrm{~d}, J=6.0 \mathrm{~Hz}, 1$, H2'), $5.53\left(\mathrm{dd}, J=7.2,15.3 \mathrm{~Hz}, 1, \mathrm{H} 5^{\prime}\right), 5.61\left(\mathrm{dt}, J=15.3,6.2 \mathrm{~Hz}, 1, \mathrm{H} 6^{\prime}\right), 6.01(\mathrm{~d}, J=$ $1.9 \mathrm{~Hz}, 1, \mathrm{H1}$ ), 6.35 (br s, 2, $\left.\mathrm{NH}_{2}\right), 7.83$ (s, 1, H2), 8.29 (s, 1, H8); ${ }^{13} \mathrm{C}$ NMR $\delta 25.3$ $\left(\mathrm{CH}_{3}\right), 27.1\left(\mathrm{CH}_{3}\right), 27.9\left(\mathrm{C}^{\prime}\right), 28.3(\mathrm{Boc}), 31.7\left(\mathrm{C}^{\prime}\right), 52.3(\mathrm{OMe}), 52.9\left(\mathrm{C}^{\prime}\right), 79.9$ (Boc), $84.2\left(\mathrm{C}^{\prime}\right), 84.5\left(\mathrm{C}^{\prime}\right), 87.8\left(\mathrm{C}^{\prime}\right), 90.4\left(\mathrm{C}^{\prime}\right), 114.5\left(\mathrm{CMe}_{2}\right), 120.3$ (C5), $127.8\left(\mathrm{C}^{\prime}\right)$, 133.7 (C6'), 140.0 (C8), 149.9 (C4), 152.5 (C2), 155.2 (Boc), 155.3 (C6), 173.1 (C10'); 
MS $m / z 519\left(100 \%, \mathrm{MH}^{+}\right)$. HRMS calcd for $\mathrm{C}_{24} \mathrm{H}_{34} \mathrm{~N}_{6} \mathrm{O}_{7}\left(\mathrm{M}+\mathrm{H}^{+}\right)$519.2567, found 519.2564 .

Methyl 9(S)-Amino-1,5,6,7,8,9-hexadeoxy-1-(adenin-9-yl)- $\beta$-D-ribo-dec-5(E)enofuranuronate (71a-S). Procedure C: A solution of $69-S(130 \mathrm{mg}, 0.25 \mathrm{mmol})$ in $\mathrm{CF}_{3} \mathrm{CO}_{2} \mathrm{H} / \mathrm{H}_{2} \mathrm{O}(9: 1,3 \mathrm{~mL})$ was stirred at $0{ }^{\circ} \mathrm{C}$ for $30 \mathrm{~min}$. Volatiles were evaporated and the residue was coevaporated $(3 \times$ toluene), and purified on RP-HPLC column $\left[\mathrm{CH}_{3} \mathrm{CN} / \mathrm{H}_{2} \mathrm{O}\right.$ (10:90) for $15 \mathrm{~min}$ followed by gradient $10 \rightarrow 25 \% \mathrm{CH}_{3} \mathrm{CN} / \mathrm{H}_{2} \mathrm{O}$ for 35 $\min$ at $2 \mathrm{~mL} / \mathrm{min}$ ] to give $71 \mathrm{a}-S\left(85 \mathrm{mg}, 90 \% ; t_{\mathrm{R}} 24 \mathrm{~min}\right)$ : UV $\max 260 \mathrm{~nm}(\varepsilon 14700)$, $\min 227 \mathrm{~nm}(\varepsilon) 3250) ;{ }^{1} \mathrm{H}$ NMR $\left(\mathrm{MeOH}-d_{4}\right) \delta$ 1.65-1.78 (m, 1, H8"), 1.79-1.89 (m, 1, H8'), 2.07-2.18 (m, 2, H7',7"), $3.61\left(\mathrm{t}, J=6.3 \mathrm{~Hz}, 1, \mathrm{H} 9{ }^{\prime}\right), 3.66(\mathrm{~s}, 3, \mathrm{OMe}), 4.13(\mathrm{t}, J=$ $\left.5.1 \mathrm{~Hz}, 1, \mathrm{H} 3{ }^{\prime}\right), 4.32$ (t, $\left.J=5.3 \mathrm{~Hz}, 1, \mathrm{H} 4{ }^{\prime}\right), 4.64\left(\mathrm{t}, J=4.6 \mathrm{~Hz}, 1, \mathrm{H} 2^{\prime}\right), 5.70-5.73$ (m, 2, $\left.\mathrm{H} 5^{\prime}, 6^{\prime}\right), 5.89\left(\mathrm{~d}, J=4.4 \mathrm{~Hz}, 1, \mathrm{H} 1^{\prime}\right), 8.11(\mathrm{~s}, 1, \mathrm{H} 2), 8.13(\mathrm{~s}, 1, \mathrm{H} 8) ;{ }^{13} \mathrm{C} \mathrm{NMR}\left(\mathrm{MeOH}-d_{4}\right)$ $\delta 28.9\left(\mathrm{C}^{\prime}\right), 33.3\left(\mathrm{C} 8^{\prime}\right), 52.9(\mathrm{OMe}), 54.0\left(\mathrm{C}^{\prime}\right), 75.03\left(\mathrm{C}^{\prime}\right), 75.66\left(\mathrm{C} 3^{\prime}\right), 86.29\left(\mathrm{C} 4{ }^{\prime}\right)$, $90.2\left(\mathrm{C}^{\prime}\right), 120.6(\mathrm{C} 5), 130.4\left(\mathrm{C}^{\prime}\right), 134.1\left(\mathrm{C}^{\prime}\right), 141.3$ (C8), $150.6(\mathrm{C} 4), 153.9$ (C2), 157.3 (C6), $174.7\left(\mathrm{C} 10^{\prime}\right)$; $\mathrm{MS} \mathrm{m} / z 379\left(100 \%, \mathrm{MH}^{+}\right)$. HRMS calcd. for $\mathrm{C}_{16} \mathrm{H}_{22} \mathrm{~N}_{6} \mathrm{O}_{5}(\mathrm{M}+$ $\left.\mathrm{H}^{+}\right) 379.1730$, found 379.1724 .

Methyl 9(R/S)-Amino-1,5,6,7,8,9-hexadeoxy-1-(adenin-9-yl)-p-D-ribo-dec5(E)-enofuranuronate (71a) and Ethyl 9(R/S)-Amino-1,5,6,7,8,9-hexadeoxy-1-

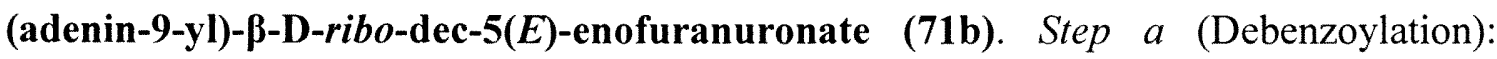
Treatment of $68 \mathrm{c}-R / S(100 \mathrm{mg}, 0.13 \mathrm{mmol})$ with $\mathrm{NH}_{3} / \mathrm{MeOH}(3 \mathrm{~mL})$ by procedure $\mathrm{B}$ gave mixture of 69 and $70\left(\sim 3: 2 ; 63 \mathrm{mg}, \sim 92 \%, 9^{\prime} R / S \sim 1: 1\right): \mathrm{MS} m / z 519\left(100 \%, \mathrm{MH}^{+}\right.$; 69), $533\left(80 \%, \mathrm{MH}^{+}\right.$; 70); HRMS calcd for $69 \mathrm{C}_{24} \mathrm{H}_{34} \mathrm{~N}_{6} \mathrm{O}_{7}\left(\mathrm{M}+\mathrm{H}^{+}\right), 519.2567$, found 519.2562; calcd for $70 \mathrm{C}_{25} \mathrm{H}_{36} \mathrm{~N}_{6} \mathrm{O}_{7}\left(\mathrm{M}+\mathrm{H}^{+}\right)$533.2724, found 533.2718. Step $b$ (Acid 
deprotection): Treatment of the above material 69/70 $(63 \mathrm{mg})$ with $\mathrm{CF}_{3} \mathrm{CO}_{2} \mathrm{H} / \mathrm{H}_{2} \mathrm{O}(9: 1,4$ $\mathrm{mL}$ ) by procedure $\mathrm{C}$ gave $71 \mathrm{a}\left(23 \mathrm{mg}, 47 \%\right.$ from $\left.\mathbf{6 8 c} ; t_{\mathrm{R}} 23 \mathrm{~min}\right)$ and $71 \mathrm{~b}(15 \mathrm{mg}, 29 \%$; $\left.t_{\mathrm{R}} 25 \mathrm{~min}\right) .71 \mathrm{a}:{ }^{1} \mathrm{H}$ NMR $\left(\mathrm{MeOH}-d_{4}\right) \delta$ 1.65-1.95 (m, 2, H8',8"), 2.07-2.22 (m, 2, H7',7"), 3.59-3.65 (m, 1, H9'), 3.66 (s, 3, OMe), 4.13 (t, $\left.J=5.1 \mathrm{~Hz}, 1, \mathrm{H} 3^{\prime}\right), 4.30-4.39$ (m, 1, H4'), $4.64\left(\mathrm{t}, J=4.6 \mathrm{~Hz}, 1, \mathrm{H} 2^{\prime}\right), 5.70-5.74\left(\mathrm{~m}, 2, \mathrm{H} 5^{\prime}, 6^{\prime}\right), 5.89$ (d, $\left.J=4.4 \mathrm{~Hz}, 1, \mathrm{H} 1^{\prime}\right), 8.11(\mathrm{br}$ s, 1, H2), 8.13 (s, 1, H8); ${ }^{13} \mathrm{C} \mathrm{NMR}\left(\mathrm{MeOH}-d_{4}\right) \delta 28.9$ (C7'), 33.3 (C8'), $52.9(\mathrm{OMe}), 54.0$ (C9'), $75.03 \& 75.10\left(\mathrm{C}^{\prime}\right), 75.66 \& 75.68\left(\mathrm{C}^{\prime}\right), 86.29 \& 86.35$ (C4'), $90.2\left(\mathrm{C}^{\prime}\right), 120.6$ (C5), 130.4 (C5'), 134.1 (C6'), 141.3 (C8), 150.6 (C4), 153.9 (C2), 157.3 (C6), 174.7 ( $\left.\mathrm{Cl}^{\prime}\right)$; HRMS calcd. for $\mathrm{C}_{16} \mathrm{H}_{22} \mathrm{~N}_{6} \mathrm{O}_{5}\left(\mathrm{M}+\mathrm{H}^{+}\right)$379.1730, found 379.1724. Anal. Calcd. for $\mathrm{C}_{16} \mathrm{H}_{22} \mathrm{~N}_{6} \mathrm{O}_{5}(378.38): C, 50.79 ; \mathrm{H}, 5.86 ; \mathrm{N}, 22.21$. Found: $\mathrm{C}, 51.11 ; \mathrm{H}, 6.20 ; \mathrm{N}$, 21.85. 71b: UV max $260 \mathrm{~nm}(\varepsilon 13900)$, $\min 228 \mathrm{~nm}\left(\varepsilon\right.$ 3600); ${ }^{1} \mathrm{H} \mathrm{NMR}\left(\mathrm{MeOH}-d_{4}\right) \delta$ $1.22\left(\mathrm{t}, J=7.2 \mathrm{~Hz}, 3, \mathrm{CH}_{3}\right), 1.81-1.96$ (m, 2, H8',H8"), 2.10-2.21 (m, 2, H7',7"), 3.88 (t, $J$ $=6.4 \mathrm{~Hz}, 1, \mathrm{H} 9 '), 4.15-4.21\left(\mathrm{~m}, 3, \mathrm{H} 3 ', \mathrm{CH}_{2}\right), 4.33\left(" \mathrm{t} ", J=5.1 \mathrm{~Hz}, 1, \mathrm{H} 4{ }^{\prime}\right), 4.64-4.67(\mathrm{~m}$, 1, H2'), 5.68-5.76 (m, 2, H5',6'), 5.90 (d, $\left.J=4.2 \mathrm{~Hz}, 1, \mathrm{H} 1^{\prime}\right), 8.11$ (s, 1, H2), 8.13 (br s, 1, $\mathrm{H} 8) ;{ }^{13} \mathrm{C}$ NMR $\left(\mathrm{MeOH}-d_{4}\right) \delta 14.3\left(\mathrm{CH}_{3}\right), 28.5\left(\mathrm{C}^{\prime}\right), 31.2\left(\mathrm{C} 8^{\prime}\right), 53.4\left(\mathrm{C}^{\prime}\right), 63.5\left(\mathrm{CH}_{2}\right)$, $74.89 \& 74.94\left(\mathrm{C}^{\prime}\right), 75.6\left(\mathrm{C}^{\prime}\right), 86.09 \& 86.14\left(\mathrm{C} 4^{\prime}\right), 90.33 \& 90.37\left(\mathrm{C} 1^{\prime}\right), 120.7(\mathrm{C} 5)$, $130.98 \& 131.00\left(\mathrm{C}^{\prime}\right), 133.09 \& 133.25\left(\mathrm{C} 66^{\prime}\right), 141.4(\mathrm{C} 8), 150.6(\mathrm{C} 4), 153.9(\mathrm{C} 2), 157.4$ (C6), $170.8\left(\mathrm{C} 10^{\prime}\right)$. HRMS calc. for $\mathrm{C}_{17} \mathrm{H}_{24} \mathrm{~N}_{6} \mathrm{O}_{5}\left(\mathrm{M}+\mathrm{H}^{+}\right)$393.1886, found 393.1881 . Anal. Calcd. for $\mathrm{C}_{17} \mathrm{H}_{24}-\mathrm{N}_{6} \mathrm{O}_{5}$ (392.18): C, 52.03; H, 6.16; N, 21.42. Found: C, 52.32; H, $6.54 ; \mathrm{N}, 20.99$.

\section{9(R/S)-Amino-1,5,6,7,8,9-hexadeoxy-1-(adenin-9-yl)- $\beta$-D-ribo-dec-5(E)-}

enofuranuronic acid (72). Procedure $\mathrm{D} . \mathrm{NaOH} / \mathrm{H}_{2} \mathrm{O}(1 \mathrm{M}, 0.5 \mathrm{~mL})$ was added to a solution of $71 \mathbf{b}(25 \mathrm{mg}, 0.06 \mathrm{mmol})$ in $\mathrm{MeOH}(4 \mathrm{~mL})$ and stirring was continued at 
ambient temperature overnight. The resulting mixture was neutralized with $\mathrm{AcOH}$ to $\mathrm{pH}$ $\sim 7$. Volatiles were evaporated and the residue was purified by RP-HPLC $\left[\mathrm{CH}_{3} \mathrm{CN} / \mathrm{H}_{2} \mathrm{O}\right.$ (5:95), $\left.t_{\mathrm{R}} 15 \mathrm{~min}\right]$ to give $72(17 \mathrm{mg}, 80 \%)$ : ${ }^{1} \mathrm{H}$ NMR $\left(\mathrm{MeOH}-d_{4}\right) \delta 1.87-1.95\left(\mathrm{~m}, 1, \mathrm{H} 8{ }^{\prime}\right)$, 1.96-2.05 (m, 1, H8"), 2.22-2.30 (m, 2, H7',7"), 3.53 (dd, $\left.J=2.4,6.1 \mathrm{~Hz}, 0.5, \mathrm{H} 9^{\prime}\right), 3.55$ (dd, $\left.J=2.4,6.1 \mathrm{~Hz}, 0.5, \mathrm{H} 9{ }^{\prime}\right), 4.24\left(\mathrm{t}, J=5.2,0.5, \mathrm{H} 3^{\prime}\right), 4.26\left(\mathrm{t}, J=5.2,0.5, \mathrm{H} 3^{\prime}\right), 4.42(\mathrm{t}$, $\left.J=5.9 \mathrm{~Hz}, 1, \mathrm{H} 4^{\prime}\right), 4.74\left(\mathrm{t}, J=4.6 \mathrm{~Hz}, 1, \mathrm{H} 2^{\prime}\right), 5.85\left(\mathrm{ddd}, J=1.8,6.0,15.7 \mathrm{~Hz}, 1, \mathrm{H} 6^{\prime}\right)$, $5.81\left(\mathrm{dd}, J=6.3,15.7 \mathrm{~Hz}, 1, \mathrm{H} 5^{\prime}\right), 6.02$ (d, $J=4.3 \mathrm{~Hz}, 1, \mathrm{H} 1$ '), 8.23 (s, 1, H2), 8.26 (s, $0.5, \mathrm{H} 8), 8.27$ (s, 0.5, H8); MS m/z $365\left(100 \%, \mathrm{MH}^{+}\right)$. HRMS calcd. for $\mathrm{C}_{15} \mathrm{H}_{20} \mathrm{~N}_{6} \mathrm{O}_{5}(\mathrm{M}$ $\left.+\mathrm{H}^{+}\right) 365.1573$ found 365.1568

Note: Treatment of 71a $(15 \mathrm{mg}, 0.04 \mathrm{mmol})$ with $\mathrm{NaOH}(1 \mathrm{M}, 0.4 \mathrm{~mL})$ by procedure D also gave $72(11.8 \mathrm{mg}, 82 \%)$.

9(R/S)-Amino-5-bromo-1,5,6,7,8,9-hexadeoxy-1-(adenin-9-yl)- $\beta$-D-ribo-dec5(Z)-enofuranuronic acid (82). Procedure E: Step a (Bromination): Pyridinium tribromide (40 mg, $0.12 \mathrm{mmol})$ was added to a solution of $68 \mathrm{c}-R / S(62 \mathrm{mg}, 0.083 \mathrm{mmol})$ in dioxane and the resulting mixture was stirred at ambient temperature for $8 \mathrm{~h}$. Volatiles were evaporated and the residue was partitioned $\left(\mathrm{NaHCO}_{3} / / \mathrm{H}_{2} \mathrm{O} / \mathrm{EtOAc}\right)$. The organic layer was washed (brine), dried $\left(\mathrm{Na}_{2} \mathrm{SO}_{4}\right)$ and evaporated to give crude $\mathbf{7 8}$ of sufficient purity for direct use in next step: MS $m / z 903\left(55 \%, \mathrm{MH}^{+}\left[{ }^{81} \mathrm{Br}_{2}\right]\right), 901(100 \%$, $\left.\mathrm{MH}^{+}\left[{ }^{81 / 79} \mathrm{Br}_{2}\right]\right), 899\left(50 \%, \mathrm{MH}^{+}\left[{ }^{79} \mathrm{Br}_{2}\right]\right)$. Step $b$ (Dehydrobromination): DBU $(0.3 \mathrm{~mL})$ was added to a solution of the crude $\mathbf{7 8}$ in dried THF $(3 \mathrm{~mL})$ and the resulting mixture was stirred at room temperature overnight. Volatiles were evaporated and the residue was partitioned $\left(\mathrm{NaHCO}_{3} / / \mathrm{H}_{2} \mathrm{O} / \mathrm{EtOAc}\right)$. The organic layer was washed (brine), dried $\left(\mathrm{Na}_{2} \mathrm{SO}_{4}\right)$, evaporated and chromatographed $(30 \rightarrow 90 \%$ EtOAc/Hexane $)$ to give $79 \mathbf{b}\{48$ 
$\mathrm{mg}, 70 \%$ from 68c; MS $m / z 821\left(100 \%, \mathrm{MH}^{+}\left[{ }^{81} \mathrm{Br}\right], 819\left(95 \%, \mathrm{MH}^{+}\left[{ }^{79} \mathrm{Br}\right]\right\}\right.$ and the corresponding $N^{6}$ monobenzoylated product 79a $\{12 \mathrm{mg}, 20 \%$ from $68 \mathrm{c} ; \mathrm{MS} \mathrm{m} / \mathrm{z} 717$ $\left(100 \%, \mathrm{MH}^{+}\left[{ }^{81} \mathrm{Br}\right]\right), 715\left(95 \%, \mathrm{MH}^{+}\left[{ }^{79} \mathrm{Br}\right]\right\}$. Step $c$ (Debenzoylation): Treatment of $79 \mathrm{~b}$ and the $N^{6}$ monobenzoylated material 79a from step b with $\mathrm{NH}_{3} / \mathrm{MeOH}$ at $0{ }^{\circ} \mathrm{C}$ by procedure B (24 h) gave 80 as a 1:1 mixture of methyl and ethyl esters of sufficient purity for direct use in next step: MS $m / z 599\left(100 \%, \mathrm{MH}^{+}\left[{ }^{81} \mathrm{Br}\right]\right), 597\left(99 \%, \mathrm{MH}^{+}\left[{ }^{79} \mathrm{Br}\right]\right)$ for $80(\mathrm{R}=\mathrm{Me})$ and $613\left(97 \%, \mathrm{MH}^{+}\left[{ }^{81} \mathrm{Br}\right]\right), 611\left(95 \%, \mathrm{MH}^{+}\left[{ }^{79} \mathrm{Br}\right]\right)$ for $80(\mathrm{R}=\mathrm{Et})$. Step $d$ (Acid deprotection): Treatment of $\mathbf{8 0}$ with $\mathrm{CF}_{3} \mathrm{CO}_{2} \mathrm{H}_{/} \mathrm{H}_{2} \mathrm{O}(9: 1,3 \mathrm{~mL})$ by procedure $\mathrm{C}$ gave $81\left(33 \mathrm{mg}, t_{\mathrm{R}} 22 \mathrm{~min}\right)$ as $\sim 1: 1$ mixture of methyl and ethyl esters: MS $\mathrm{m} / z 459$ $\left(99 \%, \mathrm{MH}^{+}\left[{ }^{81} \mathrm{Br}\right]\right), 457\left(100 \%, \mathrm{MH}^{+}\left[{ }^{79} \mathrm{Br}\right]\right)$ for $81(\mathrm{R}=\mathrm{Me})$ and $473\left(86 \%, \mathrm{MH}^{+}\left[{ }^{81} \mathrm{Br}\right]\right)$, $471\left(83 \%, \mathrm{MH}^{+}\left[{ }^{79} \mathrm{Br}\right]\right)$ for $\mathbf{8 1}(\mathrm{R}=\mathrm{Et})$. Step e (Saponification): Treatment of $\mathbf{8 1}(33 \mathrm{mg})$ with $\mathrm{NaOH}(0.5 \mathrm{~mL}, 1 \mathrm{M})$ by procedure D gave $82(20 \mathrm{mg}, 54 \%$ overall yield from $68 \mathrm{c}$; $\left.t_{\mathrm{R}} 19 \mathrm{~min}\right): \mathrm{UV} \max 259 \mathrm{~nm}(\varepsilon 14100), \min 227 \mathrm{~nm}(\varepsilon 4100) ;{ }^{1} \mathrm{H} \mathrm{NMR}\left(\mathrm{MeOH}-d_{4}\right) \delta$ $1.86-2.09$ (m, 2, H8',8"), 2.39-2.49 (m, 2, H7',7"), 3.58-3.61 (m, 1, H9'), 4.52 ("q", $J=$ $\left.5.7 \mathrm{~Hz}, 1, \mathrm{H} 3^{\prime}\right), 4.67-4.70\left(\mathrm{~m}, 1, \mathrm{H} 2^{\prime}\right), 4.98\left(\mathrm{~d}, J=6.7 \mathrm{~Hz}, 0.5, \mathrm{H} 4^{\prime}\right), 5.01(\mathrm{~d}, J=6.4 \mathrm{~Hz}$, $0.5, \mathrm{H} 4$ '), $6.11\left(\mathrm{~d}, J=2.9 \mathrm{~Hz}, 1, \mathrm{H} 1^{\prime}\right), 6.40\left(\mathrm{t}, J=7.6 \mathrm{~Hz}, 1, \mathrm{H} 66^{\prime}\right), 8.23$ (s, 1, H2), 8.39 (s, 0.5, H8), $8.40(\mathrm{~s}, 0.5, \mathrm{H} 8) ;{ }^{13} \mathrm{C} \mathrm{NMR}\left(\mathrm{MeOH}-d_{4}\right) \delta 26.7 \& 26.9$ (C7'), $32.06\left(\mathrm{C}^{\prime}\right), 55.35$ \& $55.42\left(\mathrm{C}^{\prime}\right), 74.15 \& 74.33\left(\mathrm{C} 3^{\prime}\right), 75.43 \& 75.48$ (C2'), $81.35 \& 81.52\left(\mathrm{C}^{\prime}\right), 90.00 \&$ 90.29 (C1'), 120.1 (C5), $125.13 \& 125.15$ (C5'), 138.7 (C6'), $140.72 \& 140.79$ (C8), $150.57 \& 150.63$ (C4), 154.0 (C2), 157.4 (C6), 174.0 (C10'); MS m/z 445 (100\%, $\left.\mathrm{MH}^{+}\left[{ }^{81} \mathrm{Br}\right]\right), 443\left(98 \%, \mathrm{MH}^{+}\left[{ }^{79} \mathrm{Br}\right]\right)$. HRMS calcd for $\mathrm{C}_{15} \mathrm{H}_{19}{ }^{79} \mathrm{BrN}_{6} \mathrm{O}_{5}\left(\mathrm{M}+\mathrm{H}^{+}\right)$ 443.0678, found 443.0673 . 
Diethyl fluoro(phenylsulfonyl)methylphosphonate. Step a: Oxidation. A solution of oxone $(20.11 \mathrm{~g}, 32.7 \mathrm{mmol}, 50 \%$ reagent $)$ in deionized $-\mathrm{H}_{2} \mathrm{O}(150 \mathrm{~mL})$ was added slowly to a diethyl (phenylthiomethyl)phosphonate $(2.00 \mathrm{~g}, 7.9 \mathrm{mmol})$ dissolved in $\mathrm{MeOH}(40 \mathrm{~mL})$ at $0{ }^{0} \mathrm{C}$. A white precipitate was formed immediately and the heterogeneous reaction was left stirring at ambient temperature for $4 \mathrm{~h}$. The volatiles were evaporated and the residue was partitioned between $\mathrm{H}_{2} \mathrm{O} / \mathrm{CHCl}_{3}$ to give diethyl (phenylsulfonyl)methylphosphonate (2.10 g, 92\%). Step b: Fluorination. LHMDS (1M, $9.16 \mathrm{~mL}, 9.16 \mathrm{mmol}$ ) was added dropwise to a stirred solution of diethyl (phenylsulfonyl)methylphosphonate $(2.10 \mathrm{~g}, 7.32 \mathrm{mmol})$ in dried THF $(25 \mathrm{~mL})$ under $\mathrm{N}_{2}$ at $-78{ }^{\circ} \mathrm{C}$. After $30 \mathrm{~min}$ Selectfluor $(3.90 \mathrm{~g}, 11.0 \mathrm{mmol})$ was added and the heterogeneous reaction mixture was stirred for $5 \mathrm{~min}$. DMF $(15 \mathrm{~mL})$ was added and the resulting yellow solution was allowed to warm to $0{ }^{\circ} \mathrm{C}$ and stirring was continued for 3.0 h. $\mathrm{CHCl}_{3}(10 \mathrm{~mL})$ and saturated $\mathrm{NH}_{4} \mathrm{Cl} / \mathrm{H}_{2} \mathrm{O}(10 \mathrm{~mL})$ were added and the volatiles were evaporated. The residue was partitioned $\left(\mathrm{NaHCO}_{3} / \mathrm{H}_{2} \mathrm{O} / / \mathrm{CHCl}_{3}\right)$ and the organic layer was washed (brine), dried $\left(\mathrm{Na}_{2} \mathrm{SO}_{4}\right)$, evaporated and chromatographed (90:10 EtOAc/hexanes) to give diethyl fluoro(phenylsulfonyl)methyl phosphonate ${ }^{130}$ ( $1.9 \mathrm{~g}$, $85 \%)$.

(E/Z)-1-Fluoro-2-phenyl-1-(phenylsulfonyl)ethene $\quad(84 a)$. Procedure F. LHMDS (1.0 M/THF, $2.0 \mathrm{~mL}, 2.0 \mathrm{mmol}$ ) was added dropwise to a stirred solution of diethyl fluoro(phenylsulfonyl)methylphosphonate $(0.5 \mathrm{~g}, 1.61 \mathrm{mmol})$ in dried THF $(8$ $\mathrm{mL})$ under $\mathrm{N}_{2}$ at $-78{ }^{\circ} \mathrm{C}$. After $30 \mathrm{~min}, 83 \mathrm{a}(0.18 \mathrm{~mL}, 0.19 \mathrm{~g}, 1.77 \mathrm{mmol})$ was added and the resulting yellow solution was allowed to warm to $-30{ }^{0} \mathrm{C}$ over $1.5 \mathrm{~h}$. Saturated $\mathrm{NH}_{4} \mathrm{Cl} / \mathrm{H}_{2} \mathrm{O}(\sim 1 \mathrm{~mL})$ was added, volatiles were evaporated and the residue was 
partitioned $\left(\mathrm{NaHCO}_{3} / \mathrm{H}_{2} \mathrm{O} / / \mathrm{CHCl}_{3}\right)$. The organic layer was washed (brine), dried $\left(\mathrm{Na}_{2} \mathrm{SO}_{4}\right)$, evaporated and chromatographed $\left(\mathrm{CHCl}_{3}\right)$ to give $\mathbf{8 4 a}{ }^{131}(E / Z, 95: 5 ; 0.36 \mathrm{~g}$, $85 \%$ ). Crystallization of the crude product (without chromatography) from $\mathrm{MeOH}$ also afforded 84a (E/Z, 95:5).

(E/Z)-1-Fluoro-4-(phenylsulfonyl)-1-butene (84b). Subjection of $83 \mathrm{~b}(0.23 \mathrm{~mL}$, $0.24 \mathrm{~g}, 1.77 \mathrm{mmol})$ to procedure F gave $\mathbf{8 4} \mathbf{b}^{132}(E / Z, 71: 29 ; 0.42 \mathrm{~g}, 90 \%)$.

(E/Z)-1-Fluoro-3-benzyloxy-1-(phenylsulfonyl)-1-propene (84c). Subjection of 83c $(0.1 \mathrm{~mL}, 0.10 \mathrm{~g}, 0.71 \mathrm{mmol})$ to procedure $\mathrm{F}$, gave $84 \mathrm{c}(E / Z, 63: 37 ; 0.18 \mathrm{~g}, 92 \%):{ }^{1} \mathrm{H}$ NMR $\delta 4.24(\mathrm{~m}, 2, \mathrm{H} 3, E), 4.54(\mathrm{~s}, 2, \mathrm{Bz})(E), 4.60(\mathrm{~s}, 2, \mathrm{Bz})(Z), 4.68$ (m, 2, H3), (Z), $6.03(\mathrm{dt}, J=21.9,4.9 \mathrm{~Hz}, 1, \mathrm{H} 2)(\mathrm{Z}), 6.40(\mathrm{dt}, J=32.7,5.0 \mathrm{~Hz}, 1, \mathrm{H} 2)(\mathrm{E}), 7.30-7.45$ (m, 5, Ph), $7.58(\mathrm{t}, J=5.7 \mathrm{~Hz}, 2, \mathrm{Ph}), 7.70-7.76(\mathrm{~m}, 1, \mathrm{Ph}), 7.95(\mathrm{t}, J=7.8 \mathrm{~Hz}, 2, \mathrm{Ph}) ;{ }^{13} \mathrm{C}$ NMR $\delta: 62.78\left(\mathrm{~d}, J_{\mathrm{C}-\mathrm{F}}=3.1 \mathrm{~Hz}, \mathrm{CH}_{2}, \mathrm{C} 3, Z\right), 63.39\left(\mathrm{~d}, J_{\mathrm{C}-\mathrm{F}}=6.1 \mathrm{~Hz}, \mathrm{CH}_{2}, \mathrm{C} 3, E\right)$, $128.31(\mathrm{CH}, \mathrm{Ph}, E), 128.40(\mathrm{CH}, \mathrm{Ph}), 128.47(\mathrm{CH}, \mathrm{Ph}), 128.78(\mathrm{CH}, \mathrm{Ph}), 128.87(\mathrm{CH}$, $\mathrm{Ph}), 128.97(\mathrm{CH}, \mathrm{Ph}), 129.17(\mathrm{CH}, \mathrm{Ph}), 129.986(\mathrm{CH}, \mathrm{Ph}), 135.11(\mathrm{CH}, \mathrm{Ph}), 135.25(\mathrm{CH}$, $\mathrm{Ph}), 137.45(\mathrm{CH}, \mathrm{Ph}), 137.66(\mathrm{CH}, \mathrm{Ph}), 137.97(\mathrm{CH}, \mathrm{Ph}), 138.08(\mathrm{CH}, \mathrm{Ph}), 151.57\left(\mathrm{~d}, J_{\mathrm{C}-}\right.$ $\mathrm{F}=292.7 \mathrm{~Hz}, \mathrm{CF}, \mathrm{C} 1, Z), 153.93\left(\mathrm{~d}, J_{\mathrm{C}-\mathrm{F}}=299.7, \mathrm{CF}, \mathrm{C} 1, E\right) ;{ }^{19} \mathrm{~F}$ NMR $\delta-114.91(\mathrm{~d}, J=$ $22.6 \mathrm{~Hz}, 0.37 \mathrm{~F}, Z),-123.42(\mathrm{~d}, J=33.9 \mathrm{~Hz}, 0.63 \mathrm{~F}, E)$; GC-MS $m / z 306\left[2 \%, \mathrm{M}^{+} ; t_{\mathrm{R}}=\right.$ $25.27 \mathrm{~min}(Z)$ and $25.86 \mathrm{~min}(E)]$. HRMS(AP-ESI) Calcd for $\mathrm{C}_{16} \mathrm{H}_{15} \mathrm{FO}_{3} \mathrm{~S}\left(\mathrm{M}+\mathrm{H}^{+}\right)$: 307.0804; Found: 307.0801

(E/Z)-1-Fluoro-2-phenyl-1-(phenylsulfonyl)-1-propene (84d). Subjection of 83d $(0.21 \mathrm{~mL}, 0.21 \mathrm{~g}, 1.77 \mathrm{mmol})$ to procedure $\mathrm{F}$, gave $\mathbf{8 4 d}^{131}(E / Z, 42: 58 ; 0.37 \mathrm{~g}, 90 \%)$. Column chromatography (hexane/EtOAc, 85:15) gave fractions enriched in each isomers. 
(E/Z)-1-Fluoro-2-phenyl-1-(tributyltin)ethene (85a). Procedure G. Argon was bubbled through a solution of $\mathbf{8 4 a}(E / Z, 95: 5 ; 490 \mathrm{mg}, 1.87 \mathrm{mmol})$ in anhydrous benzene $(10 \mathrm{~mL})$ for $15 \mathrm{~min} . \mathrm{Bu}_{3} \mathrm{SnH}(0.5 \mathrm{~mL}, 544 \mathrm{mg}, 1.87 \mathrm{mmol})$ and AIBN (76.7 mg, 0.46 mmol) were added and degassing of oxygen was continued for another $10 \mathrm{~min}$. The solution was then heated $\left(85^{0} \mathrm{C}\right.$, oil bath) for $2 \mathrm{~h}$ [additional AIBN $(38 \mathrm{mg}, 0.23 \mathrm{mmol})$ and $\mathrm{Bu}_{3} \mathrm{SnH}(1.87 \mathrm{mmol}, 0.5 \mathrm{~mL})$ in degassed benzene $(2 \mathrm{~mL})$ was injected through a septum via a precision syringe pump or periodically by manual injection over the $2 \mathrm{~h}$ period]. The volatiles were evaporated and the residue was chromatographed (hexane) to give $\mathbf{8 5 a} \mathbf{a}^{131}(E / Z, 95: 5 ; 740 \mathrm{mg}, 96 \%)$.

(E/Z)-1-Fluoro-4-phenyl-1-(tributyltin)-1-butene (85b). Treatment of 84b (E/Z, 71:29; $690 \mathrm{mg}, 2.37 \mathrm{mmol})$ with $\mathrm{Bu}_{3} \mathrm{SnH}(0.636 \mathrm{~mL}, 689 \mathrm{mg}, 2.37 \mathrm{mmol})$ and AIBN (97 $\mathrm{mg}, 0.59 \mathrm{mmol})$ by procedure $\mathrm{G}$ gave $85 \mathbf{b}^{132}(E / Z, 86: 14 ; 976 \mathrm{mg}, 93 \%):{ }^{19} \mathrm{~F}$ NMR $\delta$ $99.36\left(\mathrm{~d}, J=37.6 \mathrm{~Hz}, \mathrm{dd}, J_{\mathrm{Sn}-\mathrm{F}}=263 \mathrm{~Hz}, 0.14 \mathrm{~F}, Z\right),-102.9\left(\mathrm{~d}, J=52.7 \mathrm{~Hz}, \mathrm{dd}, J_{\mathrm{Sn}-\mathrm{F}}=\right.$ $229 \mathrm{~Hz}, 0.86 \mathrm{~Hz}, E)$.

Note: Careful separation on column chromatography (hexane) gave partially separated isomers of $\mathbf{8 5 b}(E)$ ( $450 \mathrm{mg}, 43 \%)$ followed by $\mathbf{8 5 b}(E / Z, 15: 85 ; 520 \mathrm{mg}, 50 \%)$.

(E/Z)-1-Fluoro-3-benzyloxy-1-(tributyltin)-1-propene (85c). Treatment of 84c $(E / Z, 63: 37 ; 252 \mathrm{mg}, 0.87 \mathrm{mmol})$ with $\mathrm{Bu}_{3} \mathrm{SnH}(0.23 \mathrm{~mL}, 252 \mathrm{mg}, 0.87 \mathrm{mmol})$ and AIBN (71 $\mathrm{mg}, 0.43 \mathrm{mmol})$ by procedure $\mathrm{G}$ gave $85 \mathrm{c}(E / Z, 77: 23 ; 352 \mathrm{mg}, 92 \%):{ }^{1} \mathrm{H}$ NMR $\delta$ 0.90-0.97 (m, 9H, Bu), 1.00-1.03 (m, 6H, Bu), $1.29(\mathrm{q}, J=14.7 \mathrm{~Hz}, 6 \mathrm{H}, \mathrm{Bu}), 1.50-1.61$ (m, 6H, Bu), $3.91(\mathrm{~d}, J=7.47 \mathrm{~Hz}, 2, \mathrm{H} 3, Z), 4.20(\mathrm{~d}, J=6.61 \mathrm{~Hz}, 2, \mathrm{H} 3, E), 4.50(\mathrm{~s}, 2$, $\left.\mathrm{CH}_{2}, E / Z\right), 5.05(\mathrm{dt}, J=6.8,46.64 \mathrm{~Hz}, 1, \mathrm{H} 2, E), 6.05(\mathrm{dt}, J=3.2,39.5 \mathrm{~Hz}, 1, \mathrm{H} 2, Z)$, 7.30-7.40 (m, 10, Ph); ${ }^{19} \mathrm{~F}$ NMR $\delta-92.71\left(\mathrm{dd}, J_{\mathrm{Sn}-\mathrm{F}}=240.9 \mathrm{~Hz}, 16 \%, Z\right),-93.03(\mathrm{~d}, J=$ 
$35.4 \mathrm{~Hz}, 84 \%, 0.23 \mathrm{~F}, Z),-97.94\left(\mathrm{dd}, J_{\mathrm{Sn}-\mathrm{F}}=233.4 \mathrm{~Hz}, 16 \%, E\right) ;-98.25(\mathrm{~d}, J=53.5 \mathrm{~Hz}$, $84 \% 0.77 \mathrm{~F}, E)$; GC-MS $\mathrm{m} / z 399\left[18 \%, \mathrm{M}^{+}-\mathrm{Bu}\left[{ }^{120} \mathrm{Sn}\right] ; t_{\mathrm{R}}=25.59 \mathrm{~min}(Z)\right.$ and $26.18 \mathrm{~min}$ (E)]. HRMS(AP-ESI) Calcd for $\mathrm{C}_{22} \mathrm{H}_{37} \mathrm{FO}^{120} \mathrm{Sn}\left(\mathrm{M}+\mathrm{Na}^{+}\right): 479.1748$; Found:479.1747.

(E/Z)-1-Fluoro-2-phenyl-1-(tributyltin)-1-propene (85d). Treatment of $84 \mathrm{~d}$ $(E / Z, 48: 52 ; 380 \mathrm{mg}, 1.38 \mathrm{mmol})$ with $\mathrm{Bu}_{3} \mathrm{SnH}(0.37 \mathrm{~mL}, 400 \mathrm{mg}, 1.38 \mathrm{mmol})$ and AIBN (56 mg, $0.34 \mathrm{mmol})$ by procedure G gave $\mathbf{8 5} \mathbf{d}^{131}(E / Z, 45: 55 ; 555 \mathrm{mg}, 95 \%)$.

(E/Z)-1-Fluoro-1-iodo-2-phenylethene (86a). Procedure H. A solution of NIS (273 $\mathrm{mg}, 1.22 \mathrm{mmol})$ in $\mathrm{CH}_{2} \mathrm{Cl}_{2}(5 \mathrm{~mL})$ was added to $85 \mathrm{a}(E / Z, 95: 5 ; 400 \mathrm{mg}, 0.97$ mmol) dissolved in $\mathrm{CH}_{2} \mathrm{Cl}_{2}(5 \mathrm{~mL})$ at $-20{ }^{\circ} \mathrm{C}$. The reaction mixture was allowed to warm to $0{ }^{0} \mathrm{C}$ over $30 \mathrm{~min}$ and $\mathrm{NaHSO}_{3}(\sim 0.5 \mathrm{~mL})$ was added to decolorize the reaction mixture. Volatiles were evaporated and the residue was partitioned $\left(\mathrm{NaHCO}_{3} / \mathrm{H}_{2} \mathrm{O} / / \mathrm{CH}_{2} \mathrm{Cl}_{2}\right)$. The organic layer was washed (brine), dried $\left(\mathrm{Na}_{2} \mathrm{SO}_{4}\right)$, evaporated and chromatographed (hexane $\rightarrow 15 \%$ EtOAc/hexane) to give $86 \mathbf{a}^{133}(E / Z$, 95:5; $229 \mathrm{mg}, 95 \%):{ }^{19} \mathrm{~F}$ NMR $\delta-60.02(\mathrm{~d}, J=18.4 \mathrm{~Hz}, 0.05 \mathrm{~F}, Z),-62.90(\mathrm{~d}, J=36.9 \mathrm{~Hz}$, $0.95 \mathrm{~F}, E)$.

(E/Z)-1-Fluoro-1-iodo-4-phenyl-1-butene (86b). Treatment of $\mathbf{8 5 b}(E / Z, 86: 14$; $380 \mathrm{mg}, 0.87 \mathrm{mmol})$ with NIS $(0.25 \mathrm{~g}, 1.10 \mathrm{mmol})$ by procedure $\mathrm{H}$ gave $86 \mathbf{b}^{133}(E / Z$, 78:22; $221 \mathrm{mg}, 94 \%):{ }^{19} \mathrm{~F}$ NMR $\delta-66.26(\mathrm{~d}, J=16.9 \mathrm{~Hz}, 0.22 \mathrm{~F}, Z),-70.21(\mathrm{~d}, J=34.6$ $\mathrm{Hz}, 0.78 \mathrm{~F}, E)$.

Analogous treatment of $\mathbf{8 5 b}(E)(450 \mathrm{mg}, 1.02 \mathrm{mmol})$ gave $86 \mathbf{b}(E)(252 \mathrm{mg}, 91 \%)$. Analogous treatment of $\mathbf{8 5 b}(E / Z, 15: 85 ; 520 \mathrm{mg}, 1.18 \mathrm{mmol})$ gave $\mathbf{8 6 b}(E / Z, 15: 85$; $295 \mathrm{mg}, 92 \%)$. 
(E/Z)-3-Benzyloxy-1-fluoro-1-iodo-1-propene (86c). Treatment of 85c $(E / Z$, 77:23; $400 \mathrm{mg}, 0.88 \mathrm{mmol}$ ) with NIS ( $246 \mathrm{mg}, 1.09 \mathrm{mmol}$ ) by procedure $\mathrm{H}$ gave $86 \mathrm{c}$ (E/Z, 67:33; $236 \mathrm{mg}, 0.80 \mathrm{mmol}, 92 \%) .{ }^{1} \mathrm{H}$ NMR $\delta 3.91$ (dd, $J=1.9,7.1 \mathrm{~Hz}, 2, \mathrm{H} 3, Z$ ), 4.01 (dd, $J=2.9,7.1 \mathrm{~Hz}, 2, \mathrm{H} 3, E), 4.42$ (s, 2, $\left.\mathrm{CH}_{2} \mathrm{O}, E\right), 4.43$ (s, 2, $\mathrm{CH}_{2} \mathrm{O}, Z$ ), 5.44 (dt, $J$ $=7.1,34.0 \mathrm{~Hz}, 1, \mathrm{H} 2, E), 5.67(\mathrm{dt}, J=7.1,16.1 \mathrm{~Hz}, 1, \mathrm{H} 2, Z), 7.21-7.30(\mathrm{~m}, 5, \mathrm{Ph}) .{ }^{13} \mathrm{C}$ NMR $\delta: 63.62\left(\mathrm{~d}, J_{\mathrm{C}-\mathrm{F}}=4.8 \mathrm{~Hz}, \mathrm{CH}_{2}, \mathrm{C} 3, Z\right), 68.80\left(\mathrm{~d}, J_{\mathrm{C}-\mathrm{F}}=7.1 \mathrm{~Hz}, \mathrm{CH}_{2}, \mathrm{C} 3, E\right), 72.29$ $\left(\mathrm{CH}_{2} \mathrm{O}, \mathrm{E} / \mathrm{Z}\right), 115.19\left(\mathrm{~d}, J_{\mathrm{C}-\mathrm{F}}=12.4 \mathrm{~Hz}, \mathrm{C}, \mathrm{C} 1, E / Z\right), 120.19\left(\mathrm{~d}, J_{\mathrm{C}-\mathrm{F}}=7.5 \mathrm{~Hz}, \mathrm{CH}, \mathrm{C} 2\right.$, E/Z), $127.83(\mathrm{CH}, \mathrm{Ph}, E / Z), 128.45(\mathrm{CH}, \mathrm{Ph}, E / Z), 137.71(\mathrm{CH}, \mathrm{Ph}, E / Z) .{ }^{19} \mathrm{~F}$ NMR $\delta$ : $59.92(\mathrm{dt}, J=2.1,16.3 \mathrm{~Hz}, Z),-65.18(\mathrm{dt}, J=2.7,33.9 \mathrm{~Hz})$. GC-MS $m / z 292\left[2 \%, \mathrm{M}^{+} ; t_{\mathrm{R}}\right.$ $=15.09 \min (Z)$ and $15.48 \min (E)$ ]. Anal. Calcd. for $\mathrm{C}_{10} \mathrm{H}_{10} \mathrm{FIO}$ (291.97): C, 41.12; H, 3.45; Found: C, 41.56; H, 3.87 .

(E/Z)-1-Fluoro-1-iodo-2-phenyl-1-propene (86d). Treatment of $85 \mathrm{~d}(E / Z$, 45:55; $450 \mathrm{mg}, 1.06 \mathrm{mmol}$ ) with NIS (300 $\mathrm{mg}, 1.32 \mathrm{mmol}$ ) by procedure $\mathrm{H}$ gave $\mathbf{8 6 \mathbf { d }}$ (E/Z, 49:51; $263 \mathrm{mg}, 95 \%) .{ }^{1} \mathrm{H}$ NMR $\delta: 2.18(\mathrm{~d}, J=3.7 \mathrm{~Hz}, 1, \mathrm{H} 3, E), 2.21(\mathrm{~d}, J=4.6$ $\mathrm{Hz}, 1, \mathrm{H} 3, \mathrm{Z}), 7.28(\mathrm{~m}, 2 \mathrm{H}, \mathrm{Ph}), 7.31(\mathrm{~m}, 2 \mathrm{H}, \mathrm{Ph}), 7.36-7.45(\mathrm{~m}, 6 \mathrm{H}, \mathrm{Ph}) .{ }^{19} \mathrm{~F}$ NMR $\delta$ $68.27 \mathrm{~Hz}(\mathrm{~s}, E),-68.81(\mathrm{~s}, Z) ; \mathrm{GC}-\mathrm{MS} m / z 262\left[100 \%, \mathrm{M}^{+} ; t_{\mathrm{R}}=10.96 \mathrm{~min}(Z)\right.$ and 12.31 $\min (E)]$. HRMS Calcd. for $\mathrm{C}_{9} \mathrm{H}_{8} \mathrm{FI}\left(\mathrm{M}^{+}\right)$: 261.9655; Found: 261.9662.

(E/Z)-1-Bromo-1-fluoro-2-phenylethene (87a). Treatment of 85a $(E / Z, 95: 5$; $800 \mathrm{mg}, 1.95 \mathrm{mmol}$ ) with NBS (430 mg, $2.43 \mathrm{mmol}$ ) by procedure H (using NBS instead of NIS) gave 87a ${ }^{134}(E / Z, 93: 7 ; 390 \mathrm{mg}, 100 \%):{ }^{1} \mathrm{H}$ NMR $\delta 6.00(\mathrm{~d}, J=32.9 \mathrm{~Hz}, 0.93$, $\mathrm{H} 2, E), 6.70(\mathrm{~d}, J=15.1 \mathrm{~Hz}, 0.07, \mathrm{H} 2, Z), 7.20(\mathrm{t}, J=7.3 \mathrm{~Hz}, 2, \mathrm{Ph}), 7.30(\mathrm{t}, J=7.8 \mathrm{~Hz}$, 1, Ph), 7.45 (d, $J=7.4 \mathrm{~Hz}, 2, \mathrm{Ph}) ;{ }^{19} \mathrm{~F}$ NMR $\delta-69.5(\mathrm{~d}, J=32.7 \mathrm{~Hz} ; 0.93 \mathrm{~F}, E),-65.5(\mathrm{~d}, J$ $=15.1 \mathrm{~Hz}, 0.07 \mathrm{~F}, Z)$. 
(E/Z)-1-Fluoro-1-bromo-3-benzyloxy-1-propene (87c). Treatment of 85c $(E / Z$, $77: 23 ; 250 \mathrm{mg}, 0.55 \mathrm{mmol}$ ) with NBS (122 $\mathrm{mg}, 0.68 \mathrm{mmol}$ ) by procedure H (using NBS instead of NIS) gave 87c (E/Z, 77:23; $125 \mathrm{mg}, 93 \%):{ }^{1} \mathrm{H}$ NMR $\delta 3.97$ (dd, $J=1.9,7.1$ $\mathrm{Hz}, 2, \mathrm{H} 3, Z$ ), 4.00 (dd, $J=2.6,7.3 \mathrm{~Hz}, 2, \mathrm{H} 3, E), 4.42\left(\mathrm{~s}, \mathrm{CH}_{2} \mathrm{O}, 2, E\right), 4.43$ (s, $\mathrm{CH}_{2} \mathrm{O}, 2$, Z), $5.19(\mathrm{dt}, \mathrm{J}=7.3,30.5 \mathrm{~Hz}, 1, \mathrm{H} 2, E), 5.64(\mathrm{dt}, J=7.1,12.2 \mathrm{~Hz}, 1, \mathrm{H} 2, Z), 7.23-7.28$ $(\mathrm{m}, 5, \mathrm{Ph}) .{ }^{13} \mathrm{C}$ NMR $\delta: 63.17\left(\mathrm{CH}_{2}, \mathrm{C} 3, E\right), 63.20\left(\mathrm{CH}_{2}, \mathrm{C} 3, \mathrm{Z}\right), 66.30\left(\mathrm{CH}_{2}, \mathrm{C} 3, Z\right)$, $72.28\left(\mathrm{CH}_{2} \mathrm{O}, E / Z\right), 107.33(\mathrm{C}, \mathrm{C} 1, E), 107.49$ (C, C1, Z), $109.89(\mathrm{CH}, \mathrm{C} 2, Z), 110.00$ $(\mathrm{CH}, \mathrm{C} 2, E), 127.83(\mathrm{CH}, \mathrm{Ph}, E / Z), 128.46(\mathrm{CH}, \mathrm{Ph}, E / Z), 129.69(\mathrm{C}, \mathrm{Ph}, E / Z) ;{ }^{19} \mathrm{~F}$ NMR $\delta-66.05(\mathrm{dd}, J=2.2,13.5 \mathrm{~Hz}, Z),-70.41(\mathrm{dt}, J=2.3,30.9 \mathrm{~Hz}, E)$. GC-MS $m / z 245[2 \%$, $\mathrm{M}^{+} ; t_{\mathrm{R}}=13.11 \mathrm{~min}(Z)$ and $13.43 \mathrm{~min}(E)$. HRMS(AP-ESI) Calcd for $\mathrm{C}_{10} \mathrm{H}_{10}{ }^{79} \mathrm{BrFO}$ $\left(\mathrm{M}+\mathrm{H}^{+}\right): 244.9977$; Found: 244.9970.

(E/Z)-1-Chloro-1-fluoro-2-phenylethene (88a). Compound 85a $(E / Z, 95: 5 ; 50$ $\mathrm{mg}, 0.12 \mathrm{mmol})$ was dissolved in dried $\mathrm{CH}_{2} \mathrm{Cl}_{2}(5 \mathrm{~mL})$ and the temperature was adjusted to $-50{ }^{\circ} \mathrm{C}$. Chlorine gas was bubbled through the solution over $5 \mathrm{~min}$. until a light yellow solution was obtained and the reaction mixture was allowed to warm to $0{ }^{0} \mathrm{C}$. Volatiles were evaporated and the residue was chromatographed (hexane $\rightarrow 5 \%$ EtOAc/hexane) to give $\mathbf{8 8 a}{ }^{19}(E / Z, 93: 7 ; 13 \mathrm{mg}, 70 \%):{ }^{1} \mathrm{H}$ NMR $\delta 5.80(\mathrm{~d}, J=31.0 \mathrm{~Hz}, 1, \mathrm{H} 2, E), 6.30(\mathrm{~d}, J$ $=12.8 \mathrm{~Hz}, 1, \mathrm{H} 2, Z), 7.20(\mathrm{t}, J=7.3 \mathrm{~Hz}, 2, \mathrm{Bz}), 7.30(\mathrm{t}, J=7.8 \mathrm{~Hz}, 1, \mathrm{Bz}), 7.45(\mathrm{~d}, J=$ $7.3 \mathrm{~Hz}, 2, \mathrm{Bz}) ;{ }^{19} \mathrm{~F}$ NMR $\delta-74.0(\mathrm{~d}, J=30.5 \mathrm{~Hz}),-71.5(\mathrm{~d}, J=12.8 \mathrm{~Hz})$.

\section{Ethyl 5-Fluoro-6-phenyl-5(Z)-hexenoate (89a). Procedure I. 4-Ethoxy-4-} oxobutylzinc bromide $(0.5 \mathrm{M}, 0.60 \mathrm{~mL}, 0.30 \mathrm{mmol})$ was added via syringe to a stirring solution of $86 \mathbf{a}(E / Z, 95: 5 ; 50 \mathrm{mg}, 0.20 \mathrm{mmol})$ in dried benzene $(5 \mathrm{~mL})$ containing $\mathrm{Pd}\left(\mathrm{PPh}_{3}\right)_{4}(23 \mathrm{mg}, 0.02 \mathrm{mmol})$ under $\mathrm{N}_{2}$. Additional $\mathrm{Pd}\left(\mathrm{PPh}_{3}\right)_{4}(10 \mathrm{mg}, 0.009 \mathrm{mmol})$ and 
4-ethoxy-4-oxobutylzinc bromide $(0.270 \mathrm{~mL}, 0.135 \mathrm{mmol})$ were added to the reaction mixture over the $8 \mathrm{~h}$ period. Volatiles were evaporated and the residue was partitioned $\left(\mathrm{NaHCO}_{3} / \mathrm{H}_{2} \mathrm{O} / / \mathrm{EtOAc}\right)$. The organic layer was washed (brine), dried $\left(\mathrm{Na}_{2} \mathrm{SO}_{4}\right)$, evaporated and chromatographed (hexane $\rightarrow 15 \%$ EtOAc/hexane) to give $89 \mathbf{a}(Z)(33 \mathrm{mg}$, $70 \% ; 73 \%$ based on $E$ isomer only): ${ }^{1} \mathrm{H}$ NMR $\delta 1.26$ (t, $\left.J=7.1 \mathrm{~Hz}, 3, \mathrm{OEt}, 3 \mathrm{H}\right), 1.95$ (quint, $J=7.3 \mathrm{~Hz}, 2, \mathrm{H} 3), 2.40(\mathrm{~m}, 4, \mathrm{H} 2, \mathrm{H} 4), 4.10(\mathrm{q}, J=7.1 \mathrm{~Hz}, 2, \mathrm{OEt}), 5.50(\mathrm{~d}, J=$ $39.4 \mathrm{~Hz}, 1, \mathrm{H6}), 7.15$ (t, $J=7.2 \mathrm{~Hz}, 1, \mathrm{Ph}), 7.30$ (t, $J=7.4 \mathrm{~Hz}, 2, \mathrm{Ph}), 7.40$ (d, $J=7.4 \mathrm{~Hz}$, $\mathrm{Ph}) ;{ }^{13} \mathrm{C}$ NMR $\delta 14.64(\mathrm{OEt}), 22.05(\mathrm{C} 3), 32.34\left(\mathrm{~d}, J_{C-F}=26.9 \mathrm{~Hz}, \mathrm{C} 4\right), 33.55(\mathrm{C} 2)$, $60.82(\mathrm{OEt}), 106.92\left(\mathrm{~d}, J_{C-F}=8.5 \mathrm{~Hz}, \mathrm{C} 6\right), 127.21(\mathrm{Ph}), 128.74(\mathrm{Ph}), 128.88(\mathrm{Ph}), 133.98$ $(\mathrm{Ph}), 158.93\left(\mathrm{~d}, J_{C-F}=266.7 \mathrm{~Hz}, \mathrm{C} 5\right), 173.52(\mathrm{CO}) ;{ }^{19} \mathrm{~F}$ NMR $\delta-102.2(\mathrm{dt}, J=18.8 \mathrm{~Hz}$, $41.4 \mathrm{~Hz})$; MS $m / z 237\left(100 \%, \mathrm{MH}^{+}\right)$. Anal. Calcd. for $\mathrm{C}_{14} \mathrm{H}_{17} \mathrm{FO}_{2}$ (236.12): C, 71.16; H, 7.25; Found: C, 70.80; H, 7.16.

Treatment $(2 \mathrm{~h})$ of $86 \mathbf{a}(E / Z, 95: 5 ; 50 \mathrm{mg}, 0.20 \mathrm{mmol})$ with $\mathrm{PdCl}_{2}(\mathrm{dppb})(6.0 \mathrm{mg}$, $0.01 \mathrm{mmol})$ and 4-ethoxy-4-oxobutylzinc bromide $(0.5 \mathrm{M}, 0.74 \mathrm{~mL}, 0.37 \mathrm{mmol})$ as described in procedure I gave 89a (Z) (44 mg, 93\%, 97\% based on $E$ isomer).

Treatment of $87 \mathbf{a}(E / Z, 93: 7 ; 50 \mathrm{mg}, 0.25 \mathrm{mmol})$ with $\mathrm{Pd}\left(\mathrm{PPh}_{3}\right)_{4}(23 \mathrm{mg}, 0.25$ mmol) and 4-ethoxy-4-oxobutylzinc bromide $(0.5 \mathrm{M}, 0.74 \mathrm{~mL}, 0.37 \mathrm{mmol})$ as described in procedure I gave $89 \mathrm{a}(Z)(41 \mathrm{mg}, 70 \%, 75 \%$ based on $E$ isomer).

Treatment of 88a $(E / Z, 93: 7 ; 120 \mathrm{mg}, 0.77 \mathrm{mmol})$ with $\mathrm{Pd}\left(\mathrm{PPh}_{3}\right)_{4}(77 \mathrm{mg}, 0.06$ $\mathrm{mmol})$ and 4-ethoxy-4-oxobutylzinc bromide $(0.5 \mathrm{M}, 2.30 \mathrm{~mL}, 1.15 \mathrm{mmol})$ as described in procedure I gave $89 \mathrm{a}(Z)(145 \mathrm{mg}, 80 \% ; 86 \%$ based on $E$ isomer).

Ethyl 5-Fluoro-8-phenyl-5(Z)-octenoate (89b). Treatment of $86 \mathbf{b}(E / Z, 78: 22$; $50 \mathrm{mg}, 0.18 \mathrm{mmol})$ with $\mathrm{Pd}\left(\mathrm{PPh}_{3}\right)_{4}(20 \mathrm{mg}, 0.018 \mathrm{mmol})$ and 4-ethoxy-4-oxobutylzinc 
bromide $(0.5 \mathrm{M}, 0.54 \mathrm{~mL}, 0.27 \mathrm{mmol})$ in dried benzene $(5 \mathrm{~mL})$ as described in procedure I [ additional $\mathrm{Pd}\left(\mathrm{PPh}_{3}\right)_{4}(10 \mathrm{mg}, 0.009 \mathrm{mmol})$ and 4-ethoxy-4-oxobutylzinc bromide $(0.270 \mathrm{~mL}, 0.135 \mathrm{mmol})$ were added to the reaction mixture over the $24 \mathrm{~h}$ period ] gave $89 \mathrm{~b}(Z)\left(29 \mathrm{mg}, 60 \% ; 78 \%\right.$ based on $E$ isomer only): ${ }^{1} \mathrm{HNMR} \delta 1.25(\mathrm{t}, J=7.3 \mathrm{~Hz}, 3$, OEt), 1.79 (quint, $J=7.3 \mathrm{~Hz}, 2, \mathrm{H} 3$ ), $2.15(\mathrm{dt}, J=7.2,18.2 \mathrm{~Hz}, 2, \mathrm{H} 4), 2.28(\mathrm{t}, J=7.5$ $\mathrm{Hz}, 2, \mathrm{H} 2), 2.41$ (m, 2, H7), 2.65 (t, $J=7.8 \mathrm{~Hz}, 2, \mathrm{H} 8), 4.13$ (q, $J=6.1 \mathrm{~Hz}, 2, \mathrm{OEt}), 4.48$ (dt, $J=7.3,37.7 \mathrm{~Hz}, 1, \mathrm{H} 6), 7.20(\mathrm{t}, J=7.3 \mathrm{~Hz}, 2, \mathrm{Ph}), 7.30$ (t, $J=7.9 \mathrm{~Hz}, 1, \mathrm{Ph}), 7.45$ $(\mathrm{d}, J=7.4 \mathrm{~Hz}, 2, \mathrm{Ph}) ;{ }^{13} \mathrm{C}$ NMR $\delta 14.63\left(\mathrm{CH}_{3}, \mathrm{OEt}\right), 21.92\left(\mathrm{CH}_{2}, \mathrm{C} 3\right), 25.61\left(\mathrm{~d}, J_{C-F}=4.7\right.$ $\left.\mathrm{Hz}, \mathrm{CH}_{2}, \mathrm{C} 7\right), 31.50\left(\mathrm{CH}_{2}, \mathrm{C} 2\right), 33.50\left(\mathrm{CH}_{2}, \mathrm{C} 8\right), 36.09\left(\mathrm{CH}_{2}, \mathrm{C} 4\right), 60.69\left(\mathrm{CH}_{2}, \mathrm{OEt}\right)$, $105.32\left(\mathrm{~d}, J_{C-F}=15.5 \mathrm{~Hz}, \mathrm{CH}, \mathrm{C} 6\right), 126.25(\mathrm{CH}, \mathrm{Ph}), 128.67(\mathrm{CH}, \mathrm{Ph}), 128.81(\mathrm{CH}, \mathrm{Ph})$, $142.07(\mathrm{C}, \mathrm{Ph}), 157.93\left(\mathrm{~d}, J_{C-F}=253.7 \mathrm{~Hz}, \mathrm{CF}, \mathrm{C} 5\right), 173.60(\mathrm{C} 1, \mathrm{CO}) ;{ }^{19} \mathrm{~F}$ NMR $\delta-110.1$ (dt, $J=37.6,15.1 \mathrm{~Hz}$ ), MS m/z $265\left(100, \mathrm{MH}^{+}\right)$. HRMS (AP-ESI) Calcd for $\mathrm{C}_{16} \mathrm{H}_{21} \mathrm{FO}_{2}$ $\left(\mathrm{M}+\mathrm{Li}^{+}\right): 271.0938$; Found: 271.0940.

Analogous treatment $(12 \mathrm{~h})$ of $\mathbf{8 6 b}(E)(15 \mathrm{mg}, 0.054 \mathrm{mmol})$ produced only $89 \mathrm{~b}(Z)(11.9 \mathrm{mg}, 88 \% ; 98 \%$ quantitative yield based on GC/MS).

Analogous treatment $(24 \mathrm{~h})$ of $\mathbf{8 6 b}(E / Z, 15: 85 ; 15 \mathrm{mg}, 0.054 \mathrm{mmol})$ showed (GC/MS, ${ }^{19} \mathrm{~F}$ NMR) a conversion of the $E$ isomer into $89 \mathrm{~b}(Z)(\sim 14 \%)$ and slowly decomposition of $86 \mathrm{~b}(Z)$ but formation of $89 \mathrm{~b}(E)$ was not detected.

Analogous treatment $(8 \mathrm{~h})$ of $\mathbf{8 6 \mathbf { b }}(E / Z, 84: 16 ; 25 \mathrm{mg}, 0.09 \mathrm{mmol})$ with $\mathrm{PdCl}_{2}(\mathrm{dppb})(5 \%$ molar) and 4-ethoxy-4-oxobutylzinc bromide $(0.5 \mathrm{M}, 0.28 \mathrm{~mL}, 0.14$ $\mathrm{mmol})$ gave $89 \mathrm{~b}(Z)(19.5 \mathrm{mg}, 82 \% ; 98 \%$ based on $E$ isomer $)$.

Ethyl 5-Fluoro-6-phenyl-5(Z)-heptenoate (89d). Treatment of 86d $(E / Z, 49: 51$; $55 \mathrm{mg}, 0.21 \mathrm{mmol})$ with $\mathrm{Pd}\left(\mathrm{PPh}_{3}\right)_{4}(24 \mathrm{mg}, 0.02 \mathrm{mmol})$ and 4-ethoxy-4-oxobutylzinc 
bromide $(0.5 \mathrm{M}, 0.60 \mathrm{~mL}, 0.30 \mathrm{mmol})$ as described in procedure I (reaction was heated at $60{ }^{0} \mathrm{C}$ for $24 \mathrm{~h}$ ) gave $89 \mathrm{~d}(Z)$ (23 mg, 45\%; 94\% based on $E$ isomer): ${ }^{1} \mathrm{H}$ NMR $\delta 1.26(\mathrm{t}, J$ $=7.1 \mathrm{~Hz}, 3, \mathrm{OEt}), 1.56(\mathrm{~s}, 3, \mathrm{H} 7), 1.92-2.10(\mathrm{~m}, 2, \mathrm{H} 3), 2.40(\mathrm{dt}, J=7.1,14.4 \mathrm{~Hz}, 2, \mathrm{H} 4)$, $2.49(\mathrm{t}, J=7.2 \mathrm{~Hz}, 2, \mathrm{H} 2), 4.14$ (q, $J=7.1 \mathrm{~Hz}, 2, \mathrm{OEt}), 7.25-7.35(\mathrm{~m}, 3, \mathrm{Ph}), 7.36-7.45$ (m, 2, Ph); ${ }^{13} \mathrm{C}$ NMR $\delta 14.63\left(\mathrm{CH}_{3}, \mathrm{OEt}\right), 17.59\left(\mathrm{~d}, J=4.5 \mathrm{~Hz}, \mathrm{CH}_{3} \mathrm{C} 7\right), 22.25\left(\mathrm{CH}_{2}\right.$, C3), $28.84\left(\mathrm{~d}, J=29.11 \mathrm{~Hz}, \mathrm{CH}_{2}, \mathrm{C} 4\right), 33.59\left(\mathrm{CH}_{2}, \mathrm{C} 2\right), 60.76\left(\mathrm{CH}_{2}, \mathrm{OEt}\right), 113.50\left(\mathrm{~d}, J_{C-}\right.$ $\left.F_{F}=15.5 \mathrm{~Hz}, \mathrm{C}, \mathrm{C} 6\right), 127.08(\mathrm{CH}, \mathrm{Ph}), 128.39(\mathrm{CH}, \mathrm{Ph}), 128.55(\mathrm{CH}, \mathrm{Ph}), 138.80(\mathrm{C}, \mathrm{Ph})$, $154.5\left(\mathrm{~d}, J_{C-F}=253.5 \mathrm{~Hz}, \mathrm{C}, \mathrm{C} 5\right), 173.62(\mathrm{CO}, \mathrm{C} 1) ;{ }^{19} \mathrm{~F}$ NMR $\delta-108.19(\mathrm{t}, J=22.6 \mathrm{~Hz})$. HRMS (AP-ESI) Calcd. for $\mathrm{C}_{15} \mathrm{H}_{19} \mathrm{FO}_{2}\left(\mathrm{M}+\mathrm{Na}^{+}\right)$: 273.1266; Found: 273.1293 .

Analogous treatment $(8 \mathrm{~h})$ of $\mathbf{8 6 \mathbf { d }}(E / Z, 49: 51 ; 15 \mathrm{mg}, 0.06 \mathrm{mmol})$ with $\mathrm{PdCl}_{2}(\mathrm{dppb})(5 \%$ molar) and 4-ethoxy-4-oxobutylzinc bromide $(0.5 \mathrm{M}, 0.18 \mathrm{~mL}, 0.09$ mmol) gave in addition to $89 \mathrm{~d}(Z)$ a new product tentatively assigned as $89 \mathrm{~d}(E):{ }^{19} \mathrm{~F}$ NMR $\delta$-107.82 ("tq", $J=22.6,2.1 \mathrm{~Hz}, 0.84 \mathrm{~F}$ ), -109.91 ("tq", $J=22.5,3.4 \mathrm{~Hz}, 0.16 \mathrm{~F}$ ); GC-MS $\mathrm{m} / \mathrm{z} 250\left[8 \%, \mathrm{M}^{+} ; \mathrm{t}_{\mathrm{R}}=17.20 \mathrm{~min}(E)\right.$ and $\left.18.74 \min (Z)\right]$.

(Z)-2-Fluoro-1-phenyl-1,6-heptadiene (90a). Treatment of 86a $(E / Z, 95: 5 ; 75$ $\mathrm{mg}, 0.30 \mathrm{mmol})$ with $\mathrm{Pd}\left(\mathrm{PPh}_{3}\right)_{4}(17 \mathrm{mg}, 0.015 \mathrm{mmol})$ and 4-pentenylzinc bromide $(0.5$ $\mathrm{M}, 0.9 \mathrm{~mL}, 0.45 \mathrm{mmol})$ as described in procedure I gave $90 \mathrm{a}(Z)(37 \mathrm{mg}, 65 \% ; 69 \%$ based on $E$ isomer): ${ }^{1} \mathrm{H}$ NMR $\delta 1.70$ (q, $\left.J=7.5 \mathrm{~Hz}, 2, \mathrm{H} 4\right), 2.15$ (quint, $J=6.8 \mathrm{~Hz}, 2, \mathrm{H} 5$ ), 2.32 (dt, $J=7.7 \mathrm{~Hz}, 15.4 \mathrm{~Hz}, 2, \mathrm{H} 3$ ), 5.03 (dd, $J=1.3,10.2 \mathrm{~Hz}, 1, \mathrm{Ha} 7$ ), 5.04 (dd, $J=1.7$, $17.3 \mathrm{~Hz}, 1, \mathrm{Hb} 7), 5.45$ (d, $J=39.5 \mathrm{~Hz}, 1, \mathrm{H1}), 5.81$ (ddt, $J=7.1,10.2,17.0 \mathrm{~Hz}), 7.2(\mathrm{t}, J$ $=7.78 \mathrm{~Hz}, 1, \mathrm{Ph}), 7.32(\mathrm{~d}, J=7.3 \mathrm{~Hz}, 2, \mathrm{Ph}), 7.5(\mathrm{~d}, J=8.15 \mathrm{~Hz}, 2, \mathrm{Ph}) ;{ }^{13} \mathrm{C}$ NMR $\delta$ : $25.91\left(\mathrm{CH}_{2}, \mathrm{C} 4\right), 32.71\left(\mathrm{CH}_{2}, \mathrm{C} 5\right), 33.29\left(\mathrm{CH}_{2}, \mathrm{C} 3\right), 106.2\left(\mathrm{~d}, J_{\mathrm{C}-\mathrm{F}}=28.6 \mathrm{~Hz}, \mathrm{CH}, \mathrm{C} 1\right)$, $115.69\left(\mathrm{CH}_{2}, \mathrm{C} 7\right), 127.08(\mathrm{CH}, \mathrm{Ph}), 128.56(\mathrm{CH}, \mathrm{Ph}), 129.74(\mathrm{CH}, \mathrm{Ph}), 134.26(\mathrm{C}, \mathrm{Ph})$, 
$138.40(\mathrm{CH}, \mathrm{C} 6), 159.93\left(\mathrm{~d}, J_{\mathrm{C}-\mathrm{F}}=266.6 \mathrm{~Hz}, \mathrm{C} 2\right) ;{ }^{19} \mathrm{~F}$ NMR $\delta-101.45(\mathrm{dt}, J=18.8,41.3$ $\mathrm{Hz}$ ); GC-MS $m / z 190\left[25 \%, \mathrm{M}^{+} ; t_{\mathrm{R}}=13.97 \mathrm{~min}(Z)\right]$. Anal. Calcd. for $\mathrm{C}_{13} \mathrm{H}_{15} \mathrm{~F}$ (190.26): C, 82.07, H, 7.95. Found: C, 82.41, H, 8.15.

Also 2,3-difluoro-1,4-diphenyl-1,3-butadiene ${ }^{131}$ (6 mg, 8\%) was isolated during chromatography as a less polar compound: ${ }^{19} \mathrm{~F}$ NMR $\delta-127.95(\mathrm{dd}, J=14.6,28.6 \mathrm{~Hz})$; GC-MS $m / z 242\left[100 \%, \mathrm{M}^{+} ; t_{\mathrm{R}}=21.46 \mathrm{~min}\right]$.

(Z)-6-Fluoro-9-phenyl-1,6-nondiene (90b). Treatment of 86b $(E / Z, 78: 22 ; 70$ $\mathrm{mg}, 0.26 \mathrm{mmol})$ with $\mathrm{Pd}\left(\mathrm{PPh}_{3}\right)_{4}(15 \mathrm{mg}, 0.013 \mathrm{mmol})$ and 4-pentenylzinc bromide $(0.77$ $\mathrm{mL}, 0.38 \mathrm{mmol})$ in dried benzene $(5 \mathrm{~mL})$ as described in procedure I [additional $\mathrm{Pd}\left(\mathrm{PPh}_{3}\right)_{4}(8 \mathrm{mg}, 0.007 \mathrm{mmol})$ and 4-pentenylzinc bromide $(0.4 \mathrm{~mL}, 0.2 \mathrm{mmol})$ were added to the reaction mixture] gave $90 \mathrm{~b}(Z)$ ( $43 \mathrm{mg}, 76 \%$; $98 \%$ based on $E$ isomer): ${ }^{1} \mathrm{H}$ NMR $\delta 1.55(\mathrm{q}, J=7.7 \mathrm{~Hz}, 2, \mathrm{H} 4), 2.04-2.20(\mathrm{~m}, 4, \mathrm{H} 3, \mathrm{H} 5), 2.38(\mathrm{dt}, J=7.6,15.0 \mathrm{~Hz}$, 2, H8), 2.65 (t, $J=7.3 \mathrm{~Hz}, 2, \mathrm{H} 9), 4.45$ (dt, $J=7.4,37.9 \mathrm{~Hz}, 1, \mathrm{H} 7), 4.65-5.05$ ( m, 1, $\mathrm{H} 1)$, 5.75-5.85 (m, 1, H2), 7.18-7.25 (m, 3, Ph), 7.30-7.35 (m, 2, Ph); ${ }^{13} \mathrm{C}$ NMR $\delta 23.04$ $\left(\mathrm{CH}_{2} \mathrm{C} 4\right), 25.75\left(\mathrm{CH}_{2}, \mathrm{C} 8\right), 31.5\left(\mathrm{CH}_{2}, \mathrm{C} 3\right), 33.18\left(\mathrm{CH}_{2}, \mathrm{C} 9\right), 36.19\left(\mathrm{CH}_{2}, \mathrm{C} 5\right), 104.64$ $\left(\mathrm{d}, J_{\mathrm{C}-\mathrm{F}}=15.6 \mathrm{~Hz}, \mathrm{CH}, \mathrm{C} 7\right), 115.40\left(\mathrm{CH}_{2}, \mathrm{C} 1\right), 126.24(\mathrm{CH}, \mathrm{Ph}), 128.68(\mathrm{CH}, \mathrm{Ph}), 128.85$ $(\mathrm{CH}, \mathrm{Ph}), 138.58(\mathrm{C}, \mathrm{Ph}), 142.18(\mathrm{CH}, \mathrm{C} 2), 158.76\left(\mathrm{~d}, J_{\mathrm{C}-\mathrm{F}}=253.7 \mathrm{~Hz}, \mathrm{CF} \mathrm{C} 6\right) ;{ }^{19} \mathrm{~F}$ NMR $\delta-109.65(\mathrm{dt}, J=15.0,41.3 \mathrm{~Hz})$. MS m/z $219\left(100 \%, \mathrm{MH}^{+}\right)$. Anal. Calcd. for $\mathrm{C}_{15} \mathrm{H}_{19} \mathrm{~F}$ (218.15): C, 82.53, H, 8.77. Found: C, 82.43, H, 8.80.

The ${ }^{19} \mathrm{~F}$ NMR of the crude reaction mixture in addition to $90 \mathrm{~b} Z(0.73 \mathrm{~F})$ showed the presence of the $E$-isomer of $90 \mathbf{b}[-104.71 \mathrm{ppm}(\mathrm{dt}, J=22.6,64.0 \mathrm{~Hz}, 0.12 \mathrm{~F})]$ in addition to the by-product tentatively as (Z)-1-fluoro-4-phenyl-1-butene [ ${ }^{19}$ F NMR $\delta$ - 
$130.33(\mathrm{dd}, J=41.4,82.8 \mathrm{~Hz}, 0.03 \mathrm{~F})$ and (Z,Z)-4,5-difluoro-1,8-diphenyl-3,5-octadiene [ $-132.34 \mathrm{ppm}(\mathrm{dd}, J=13.2,26.3 \mathrm{~Hz}, 0.10 \mathrm{~F})]$.

(E/Z)- 6-Fluoro-8-benzyloxy-1,6-octadiene (90c). Treatment of 86c $(E / Z, 67: 33$; $63 \mathrm{mg}, 0.215 \mathrm{mmol}$ ) with $\mathrm{PdCl}_{2}(\mathrm{dppb})$ ( $5 \%$ molar ) and 4-pentenylzinc bromide $(0.5 \mathrm{M}$, $0.86 \mathrm{~mL}, 0.43 \mathrm{mmol})$ as described in procedure I $\left[55^{\circ} \mathrm{C}\right.$ for $8 \mathrm{~h}$ ] gave $90 \mathrm{c}(E / Z, 80: 20$, $46 \mathrm{mg}, 86 \%$ ). ${ }^{1} \mathrm{H}$ NMR $\delta 1.55$ (quint, $J=7.4 \mathrm{~Hz}, 2, \mathrm{H} 4, E / Z$ ), 1.98-2.04 (m, 2, H5, E/Z), $2.08-2.19(\mathrm{~m}, 2, \mathrm{H} 3, E / Z), 3.87\left(\mathrm{~d}, J=7.8 \mathrm{~Hz}, 0.4, \mathrm{OCH}_{2}, Z\right), 4.02(\mathrm{~d}, J=7.1 \mathrm{~Hz}, 1.6$, $\left.\mathrm{OCH}_{2}, E\right), 4.41\left(\mathrm{~s}, 2, \mathrm{CH}_{2} \mathrm{O}, E / Z\right), 4.66(\mathrm{dt}, J=7.2,36.7 \mathrm{~Hz}, 0.8, \mathrm{H1}, E), 4.88-4.97$ (m, 2 , $\mathrm{H} 7, E / Z), 5.17$ (dt, J = 7.8, 20.52 Hz, 0.2, H1, Z), 5.65-5.75 (m, 1, H6, E/Z), 7.20-7.27 (m, 5, Ph, E/Z); ${ }^{13} \mathrm{C}$ NMR $\delta 25.13\left(\mathrm{CH}_{2}, \mathrm{C} 4, E\right), 25.45\left(\mathrm{CH}_{2}, \mathrm{C} 4, \mathrm{Z}\right), 31.13\left(\mathrm{CH}_{2}, \mathrm{C} 5, E\right)$, $31.40\left(\mathrm{CH}_{2}, \mathrm{C} 5, \mathrm{Z}\right), 32.82\left(\mathrm{CH}_{2}, \mathrm{C} 3, \mathrm{E} / \mathrm{Z}\right), 62.70\left(\mathrm{OCH}_{2}, \mathrm{Z}\right), 62.77\left(\mathrm{OCH}_{2}, E\right), 71.86$ $\left(\mathrm{CH}_{2} \mathrm{O}, \mathrm{Z}\right), 72.06\left(\mathrm{CH}_{2} \mathrm{O}, E\right), 102.31(\mathrm{~d}$,

$\left.J_{\mathrm{C}-\mathrm{F}}=13.79 \mathrm{~Hz}, \mathrm{CH}, \mathrm{C} 1, Z\right), 102.82\left(\mathrm{~d}, J_{\mathrm{C}-\mathrm{F}}=22.85 \mathrm{~Hz}, \mathrm{CH}, \mathrm{C} 1, E\right), 115.19\left(\mathrm{CH}_{2}, \mathrm{C} 7\right.$, E/Z), 127.58 (CH, Ph, E/Z), 127.82 (CH, Ph, E/Z), 128.36 (CH, Ph, E/Z), 137.85 (C, Ph, $E / Z), 138.34(\mathrm{CH}, \mathrm{C} 6, E / Z), 160.93\left(\mathrm{~d}, J_{\mathrm{C}-\mathrm{F}}=259.1 \mathrm{~Hz}, \mathrm{CF}, \mathrm{C} 2, E\right), 162.62\left(\mathrm{~d}, J_{\mathrm{C}-\mathrm{F}}=\right.$ $254.8 \mathrm{~Hz}, \mathrm{CF}, \mathrm{C} 2, Z) ;{ }^{19} \mathrm{~F}$ NMR $\delta-98.05$ (q, $\left.J=22.8 \mathrm{~Hz}, 1, Z\right),-104.21(\mathrm{dt}, J=17.31$, $36.74 \mathrm{~Hz}, 5, E)$; GC-MS $m / z 235\left[1 \%, \mathrm{M}^{+} ; t_{\mathrm{R}}=16.95 \mathrm{~min}(Z)\right.$ and $\left.17.57 \mathrm{~min}(E)\right]$. HRMS Calcd. for $\mathrm{C}_{15} \mathrm{H}_{19} \mathrm{FO}\left(\mathrm{M}+\mathrm{H}^{+}\right)$235.1498; Found: 235.1490 .

Treatment of 86c $(E / Z, 75: 25,20 \mathrm{mg}, 0.07 \mathrm{mmol})$ with $\mathrm{Pd}\left(\mathrm{PPh}_{3}\right)_{4}(5 \%$ molar $)$ and 4-pentenylzinc bromide $(0.5 \mathrm{M}, 0.28 \mathrm{~mL}, 0.14 \mathrm{mmol})$ as described in procedure I (48 h) gave 90c $\left(56 \%,{ }^{19} \mathrm{~F}\right.$ NMR $\delta:-104.56(\mathrm{dt}, J=15.05,37.6 \mathrm{~Hz})$ in addition to unchanged 86c $(43 \%, E / Z, \sim 44: 56)$. 
Treatment of $87 \mathbf{c}(\mathrm{E} / \mathrm{Z}, 77 / 23,45 \mathrm{mg}, 0.18 \mathrm{mmol})$ with $\mathrm{PdCl}_{2}(\mathrm{dppb})(5 \%$ molar $)$ and 4-pentenylzinc bromide $(0.5 \mathrm{M}, 0.7 \mathrm{~mL}, 0.36 \mathrm{mmol})$ as described in procedure I gave 90c $(E / Z, 80: 20 ; 36 \mathrm{mg}, 84 \%)$.

(Z)-6-Fluoro-7-phenyl-1,6-octadiene (90d).Treatment of 86d (E/Z, 49:51; 65 $\mathrm{mg}, 0.25 \mathrm{mmol})$ with $\mathrm{Pd}\left(\mathrm{PPh}_{3}\right)_{4}(14.3 \mathrm{mg}, 0.012 \mathrm{mmol})$ and 4-pentenylzinc bromide $(0.5$ $\mathrm{M}, 0.75 \mathrm{~mL}, 0.38 \mathrm{mmol})$ as described in procedure $\mathrm{I}\left[55^{\circ} \mathrm{C}\right.$ for $\left.4 \mathrm{~h}\right]$ gave $90 \mathrm{~d}(Z)(23 \mathrm{mg}$, $45 \%$; 92\% based on $E$ isomer): ${ }^{1} \mathrm{H}$ NMR $\delta 1.68$ (quint, $\left.J=7.9 \mathrm{~Hz}, 2, \mathrm{H} 4\right), 1.95$ (s, 3, H8), 2.12-2.20 (m, 2, H3), 2.38 (dt, $J=7.1,23.6 \mathrm{~Hz}, 2, \mathrm{H} 5), 4.98$ (dd, $J=8.0,10.2 \mathrm{~Hz}, 2, \mathrm{H1}$ ), 5.78-5.90 (m, 1, H2), 7.15-7.38(m, 5, Ph); ${ }^{13} \mathrm{C}$ NMR $\delta 17.72\left(\mathrm{CH}_{3}, \mathrm{C} 8\right), 26.16\left(\mathrm{CH}_{2}, \mathrm{C} 4\right)$, $31.38\left(\mathrm{CH}_{2}, \mathrm{C} 5\right), 33.41\left(\mathrm{CH}_{2}, \mathrm{C} 3\right), 110.08(\mathrm{C}, \mathrm{C} 7), 115.51\left(\mathrm{CH}_{2}, \mathrm{C} 1\right) 126.99(\mathrm{CH}, \mathrm{Ph})$, $128.40(\mathrm{CH}, \mathrm{Ph}), 128.54(\mathrm{CH}, \mathrm{Ph}), 138.61(\mathrm{C}, \mathrm{Ph}), 139.02(\mathrm{CH}, \mathrm{C} 2), 154.82\left(\mathrm{~d}, J_{\mathrm{C}-\mathrm{F}}=\right.$ $255.6 \mathrm{~Hz}, \mathrm{CF}, \mathrm{C} 6) ;{ }^{19} \mathrm{~F}$ NMR $\delta-108.10(\mathrm{t}, J=23.1 \mathrm{~Hz})$; GC-MS $m / z 204\left[5 \%, \mathrm{M}^{+} ; t_{\mathrm{R}}=\right.$ 14.59 min, Z]. Anal. Calcd. for $\mathrm{C}_{14} \mathrm{H}_{17} \mathrm{FO}_{2}$ (204.28): C, 82.31; H, 8.39. Found: C, 82.56; H, 8.78.

Assesment of the reaction progress by GC-MS and ${ }^{19} \mathrm{~F}$ NMR showed the gradual conversion of the $86 \mathrm{~d}(E)$ isomer into $90 \mathrm{~d}(Z)$ [ $2 \mathrm{~h}(6 \%), 8 \mathrm{~h}(35 \%), 16 \mathrm{~h}(60 \%), 24 \mathrm{~h}$ $(92 \%)]$ while $86 \mathrm{~d}(Z)$ isomer remained unchanged.

2-Fluoro-1-phenyl-4-[2-(1,3-dioxolanyl)]-1(Z)-butene (91a). Treatment of 86a $(E / Z, 95: 5 ; 25 \mathrm{mg}, 0.10 \mathrm{mmol})$ with $\mathrm{Pd}\left(\mathrm{PPh}_{3}\right)_{4}(10 \mathrm{mg}, 0.01 \mathrm{~mL})$ and 2-[2-(1,3dioxolanyl]ethylzinc bromide $(0.5 \mathrm{M}, 0.4 \mathrm{~mL}, 0.2 \mathrm{mmol})$ as described in procedure I [additional $\mathrm{Pd}\left(\mathrm{PPh}_{3}\right)_{4}(20 \mathrm{mg}, 0.02 \mathrm{mmol})$ and 2-[2-(1,3- dioxolanyl]ethylzinc bromide $(0.8 \mathrm{~mL}, 0.4 \mathrm{mmol})$ were added to the reaction mixture over the $24 \mathrm{~h}$ period] gave $91 \mathrm{a}$ (Z) (20 mg, 90\%; 94\% based on $E$ isomer): ${ }^{1} \mathrm{H}$ NMR $\delta 1.96(\mathrm{dt}, J=4.6,11.1 \mathrm{~Hz}, 2, \mathrm{H} 4)$, 
$2.45(\mathrm{dt}, J=7.6,17.8 \mathrm{~Hz}, 2, \mathrm{H} 3), 3.85\left(\mathrm{t}, J=5.4 \mathrm{~Hz}, 2, \mathrm{CH}_{2}\right.$ dioxolanyl) $3.92(\mathrm{t}, J=5.0$ $\mathrm{Hz}, 2, \mathrm{CH}_{2}$ dioxolanyl), 4.95 (t, $\left.J=4.5 \mathrm{~Hz}, 1, \mathrm{H} 5\right), 5.50$ (d, $\left.J=39.3 \mathrm{~Hz}, 1, \mathrm{H} 1\right), 7.20$ (t, $J$ $=7.4 \mathrm{~Hz}, 2, \mathrm{Ph}), 7.30(\mathrm{t}, J=7.8 \mathrm{~Hz}, 1, \mathrm{Ph}), 7.45(\mathrm{~d}, J=7.3 \mathrm{~Hz}, 2, \mathrm{Ph}) ;{ }^{13} \mathrm{C}$ NMR $\delta 27.82$ (d, $\left.J_{\mathrm{C}-\mathrm{F}}=27.8 \mathrm{~Hz}, \mathrm{CH}_{2}, \mathrm{C} 3\right), 31.03\left(\mathrm{CH}_{2}, \mathrm{C} 4\right), 65.45\left(\mathrm{CH}_{2}, 2 \times \mathrm{CH}_{2}\right.$ from dioxolanyl), $103.74(\mathrm{CH}, \mathrm{C} 1), 106.37(\mathrm{CH}, \mathrm{C} 5), 127.16(\mathrm{CH}, \mathrm{Ph}), 128.66(\mathrm{CH}, \mathrm{Ph}), 128.81(\mathrm{CH}, \mathrm{Ph})$, $134.08(\mathrm{C}, \mathrm{Ph}), 159.25\left(\mathrm{~d}, \mathrm{~J}_{C-F}=266.2 \mathrm{~Hz}, \mathrm{CF}, \mathrm{C} 2\right)$; GC-MS $m / z 222\left[10 \%, \mathrm{M}^{+} ; t_{\mathrm{R}}=\right.$ $18.19 \mathrm{~min}, Z$ Z]. HRMS (AP-ESI) Calcd for $\mathrm{C}_{13} \mathrm{H}_{15} \mathrm{FO}_{2}\left(\mathrm{M}+\mathrm{Li}^{+}\right)$: 229.1216. Found: 229.1207 .

Effect of the Pd catalysts on the efficiency of coupling: Progress of the reactions was monitored by ${ }^{19} \mathrm{~F}$ NMR GC-MS and yields are based on ${ }^{19} \mathrm{~F}$ NMR and GC-MS of the crude reaction mixtures.

Treatment of 86a $(E / Z, 95: 5,25 \mathrm{mg}, 0.10 \mathrm{mmol})$ with $\mathrm{Pd}\left(\mathrm{Ph}_{3} \mathrm{P}\right)_{4}(5 \%$ molar $)$ and 2-[2-(1,3- dioxolanyl]ethylzinc bromide $(0.5 \mathrm{M}, 0.4 \mathrm{~mL}, 0.2 \mathrm{mmol})$ as described in procedure I $\left[2 \mathrm{~h}, 50{ }^{\circ} \mathrm{C}\right]$ gave $91 \mathrm{a}(11 \%)$ and unchanged $86 \mathrm{a}(E / Z, 95: 5,85 \%)$.

Treatment of $86 \mathbf{a}(E / Z, 95: 5,25 \mathrm{mg}, 0.10 \mathrm{mmol})$ with $\mathrm{PdCl}_{2}(\mathrm{dppf})(5 \%$ molar $)$ and 2-[2-(1,3-dioxolanyl] ethylzinc bromide $(0.5 \mathrm{M}, 0.4 \mathrm{~mL}, 0.2 \mathrm{mmol})$ as described in procedure I $\left[2 \mathrm{~h}, 50{ }^{\circ} \mathrm{C}\right]$ gave $91 \mathrm{a}(8 \%)$, unchanged $86 \mathrm{a}(E / Z, 95: 5,85 \%)$ and reduction product $(6 \%)$.

Treatment of 86a $(E / Z, 95: 5,25 \mathrm{mg}, 0.10 \mathrm{mmol})$ with $\mathrm{Pd}(\mathrm{OAc})_{2}(5 \%$ molar $)$ and 2-[2-(1,3- dioxolanyl]ethylzinc bromide $(0.5 \mathrm{M}, 0.4 \mathrm{~mL}, 0.2 \mathrm{mmol})$ as described in procedure I [3.5h, $\left.50{ }^{\circ} \mathrm{C}\right]$ gave $91 \mathbf{a}(95 \%)$. 
Treatment of 86a $(E / Z, 95: 5,25 \mathrm{mg}, 0.10 \mathrm{mmol})$ with $\mathrm{Pd}(\mathrm{dba})_{3}(5 \%$ molar $)$ and 2[2-(1,3- dioxolanyl] ethylzinc bromide $(0.5 \mathrm{M}, 0.4 \mathrm{~mL}, 0.2 \mathrm{mmol})$ as described in procedure I $\left[2 \mathrm{~h}, 50{ }^{\circ} \mathrm{C}\right]$ gave $91 \mathrm{a}(93 \%)$.

Treatment of 86a $(E / Z, 95: 5,25 \mathrm{mg}, 0.10 \mathrm{mmol})$ with $\mathrm{PdCl}_{2}(\mathrm{dppb})(5 \%$ molar$)$ and 2-[2-(1,3- dioxolanyl]ethylzinc bromide $(0.5 \mathrm{M}, 0.4 \mathrm{~mL}, 0.2 \mathrm{mmol})$ as described in procedure I $\left[2 \mathrm{~h}, 50{ }^{\circ} \mathrm{C}\right]$ gave $91 \mathrm{a}(95 \%)$.

4-Fluoro-1-phenyl-6-[2-(1,3-dioxolanyl)]-3(Z)-hexene (91b). Treatment of 86b $(E / Z, 78: 22 ; 30 \mathrm{mg}, 0.11 \mathrm{mmol})$ with $\mathrm{Pd}\left(\mathrm{PPh}_{3}\right)_{4}(7 \mathrm{mg}, 0.005 \mathrm{mmol})$ and 2-[2-(1,3dioxolanyl)]ethylzinc bromide $(0.5 \mathrm{M}, 0.44 \mathrm{~mL}, 0.22 \mathrm{mmol})$ in dried benzene $(5 \mathrm{~mL})$ as described in procedure I [additional $\mathrm{Pd}\left(\mathrm{PPh}_{3}\right)_{4}(4 \mathrm{mg}, 0.0028 \mathrm{mmol})$ and 2-[2-(1,3dioxolanyl)]ethylzinc bromide $(0.5 \mathrm{M}, 0.2 \mathrm{~mL}, 0.1 \mathrm{mmol})$ were added] gave $91 \mathrm{~b}(Z)(20$ $\mathrm{mg}, 74 \%$; 94\% based on $E$ isomer): ${ }^{1} \mathrm{H}$ NMR $\delta 1.80-1.91$ (m, 2, H6), 2.22 (dt, $J=5.0$, $17.3 \mathrm{~Hz}, 2, \mathrm{H} 5), 2.40$ (q, $J=7.5 \mathrm{~Hz}, 2, \mathrm{H} 2), 2.63$ (t, $J=7.9 \mathrm{~Hz}, 2, \mathrm{H} 1), 3.86-3.90$ (m, 2, $\mathrm{CH}_{2}$ dioxolanyl), 3.96-4.02 (m, 2, $\mathrm{CH}_{2}$ dioxolanyl), 4.50 (dt, $J=7.4,37.6 \mathrm{~Hz}, 1, \mathrm{H} 3$ ), $4.86(\mathrm{t}, J=4.6 \mathrm{~Hz}, 1, \mathrm{H} 7), 7.18-7.25(\mathrm{~m}, 3, \mathrm{Ph}), 7.28-7.35(\mathrm{~m}, 2, \mathrm{Ph}) ;{ }^{13} \mathrm{C} \mathrm{NMR} \delta: 25.60$ $\left(\mathrm{d}, J_{\mathrm{C}-\mathrm{F}}=4.9 \mathrm{~Hz}, \mathrm{CH}_{2} \mathrm{C} 2\right), 26.76\left(\mathrm{~d}, J_{\mathrm{C}-\mathrm{F}}=28.8 \mathrm{~Hz}, \mathrm{CH}_{2}, \mathrm{C} 5\right) 31.02\left(\mathrm{CH}_{2}, \mathrm{C} 6\right), 36.08$ $\left(\mathrm{CH}_{2}, \mathrm{C} 1\right), 65.26\left(\mathrm{CH}_{2}, 2 \mathrm{x} \mathrm{CH}\right.$ dioxolanyl), $103.87(\mathrm{CH}, \mathrm{C} 7), 104.68\left(\mathrm{~d}, J_{\mathrm{C}-\mathrm{F}}=15.49 \mathrm{~Hz}\right.$, $\mathrm{CH}, \mathrm{C} 3), 126.23(\mathrm{CH}, \mathrm{Ph}), 128.66(\mathrm{CH}, \mathrm{Ph}), 128.93(\mathrm{CH}, \mathrm{Ph}), 142.11(\mathrm{C}, \mathrm{Ph}), 158.24$ (d, $\left.J_{\mathrm{C}-\mathrm{F}}=253.2 \mathrm{~Hz}, \mathrm{CF}, \mathrm{C} 4\right) ;{ }^{19} \mathrm{~F}$ NMR $\delta-109.37(\mathrm{dt}, J=15.04,37.6 \mathrm{~Hz}) ; \mathrm{GC}-\mathrm{MS} m / z 250$ $\left[1 \%, \mathrm{M}^{+} ; t_{\mathrm{R}}=17.74 \mathrm{~min}, Z\right]$. FAB-HRMS: Calcd for $\mathrm{C}_{15} \mathrm{H}_{19} \mathrm{FO}_{2}\left(\mathrm{MH}^{+}\right):$251.1448; Found: 251.1455.

Analogous treatment of $86 \mathrm{~b}(E)(15 \mathrm{mg}, 0.054 \mathrm{mmol})$ produced only $91 \mathrm{~b}(Z)$ (89\%, $98 \%$ based on GC/MS). 
Analogous treatment of $\mathbf{8 6 \mathbf { b }}(E / Z, 15: 85 ; 15 \mathrm{mg}, 0.055 \mathrm{mmol})$ showed a conversion of the $E$ isomer into $91 \mathrm{~b}(Z)(\sim 14 \%)$ and disappearance of $86 \mathrm{~b}(Z)$, but no formation of $\mathbf{9 b}(E)$ was detected (GC/MS, ${ }^{19} \mathrm{~F}$ NMR).

3-Fluoro-2-phenyl-5-[2-(1,3-dioxolanyl)]-2(Z)-pentene (91d). Treatment of 86d $(E / Z, 49: 51 ; 30 \mathrm{mg}, 0.11 \mathrm{mmol})$ with $\mathrm{Pd}\left(\mathrm{PPh}_{3}\right)_{4}(6.5 \mathrm{mg}, 0.0057 \mathrm{mmol})$ and 2-[2-(1,3dioxolanyl]ethylzinc bromide $(0.45 \mathrm{~mL}, 0.23 \mathrm{mmol})$ as described in procedure I [ $60^{\circ} \mathrm{C}$ for $24 \mathrm{~h}$; additional $\mathrm{Pd}\left(\mathrm{PPh}_{3}\right)_{4}(6 \mathrm{mg}, 0.005 \mathrm{mmol})$ and 2-[2-(1,3- dioxolanyl]ethylzinc bromide $(0.45 \mathrm{~mL}, 0.23 \mathrm{mmol})$ were added to the reaction mixture over a $24 \mathrm{~h}$ period)] gave $91 \mathrm{~d}(Z)\left(12 \mathrm{mg}, 46 \%\right.$; $90 \%$ based on $E$ isomer]): ${ }^{1} \mathrm{HNMR} \delta 1.30$ (s, 3, H1), $1.94-$ 2.03 (m, 2, H4), 2.5 (dt, $J=8.1,23.1 \mathrm{~Hz}, 2, \mathrm{H} 5), 3.89-3.94\left(\mathrm{~m}, 2, \mathrm{CH}_{2}\right.$ dioxolanyl), 3.954.05 (m, 2, $\mathrm{CH}_{2}$ dioxolanyl), $4.95(\mathrm{t}, J=4.5 \mathrm{~Hz}, 1, \mathrm{H} 6), 7.20-7.38(\mathrm{~m}, 5, \mathrm{Ph}) ;{ }^{13} \mathrm{C}$ NMR $\delta$ $17.57\left(\mathrm{CH}_{3}, \mathrm{C} 1\right), 24.25\left(\mathrm{~d}, J_{\mathrm{C}-\mathrm{F}}=29.2 \mathrm{~Hz}, \mathrm{CH}_{2}, \mathrm{C} 4\right), 30.12\left(\mathrm{CH}_{2}, \mathrm{C} 5\right), 65.42\left(2 \mathrm{x} \mathrm{CH}_{2}\right.$ dioxolanyl), 103.95 (C, C2), 112.8 (CH, C6), 127.04 (CH, Ph), 128.40 (CH, Ph), 128.56 $(\mathrm{CH}, \mathrm{Ph}), 138.88(\mathrm{C}, \mathrm{Ph}), 153.8\left(\mathrm{~d}, J_{\mathrm{C}-\mathrm{F}}=255.8 \mathrm{~Hz}, \mathrm{C}, \mathrm{CF}\right) ;{ }^{19} \mathrm{~F}$ NMR $\delta-108.75(\mathrm{t}, J=$ 22.6 Hz). HRMS (ESI) Calcd for $\mathrm{C}_{14} \mathrm{H}_{17} \mathrm{FO}_{2}\left(\mathrm{M}+\mathrm{Li}^{+}\right)$: 243.1373; Found: 243.1361 .

3,3-Dimethyl-2-Fluoro-1-phenyl-1-butene (93a). Treatment of 86a $(E / Z, 95: 5$, $40 \mathrm{mg}, 0.16 \mathrm{mmol})$ with $\mathrm{PdCl}_{2}(\mathrm{dppb})(5 \%$ molar$)$ and tert-butylzinc bromide $(0.5 \mathrm{M}, 0.6$ $\mathrm{mL}, 0.32 \mathrm{mmol})$ as described in procedure $\mathrm{I}\left[3 \mathrm{~h}, 50{ }^{\circ} \mathrm{C}\right]$ gave $93 \mathrm{a}(23 \mathrm{mg}, 80 \%, 95 \%$ bsed on GC-MS and ${ }^{19} \mathrm{~F}$ NMR ): ${ }^{1} \mathrm{H}$ NMR $\delta 1.15(\mathrm{~s}, 9, t-\mathrm{Bu}), 5.40(\mathrm{~d}, J=40.7 \mathrm{~Hz}, \mathrm{H1})$, 7.17-7.41 (m, 5, Ph); ${ }^{19} \mathrm{~F}$ NMR $\delta-109.47(\mathrm{~d}, J=40.7 \mathrm{~Hz}) ;$ GC-MS $m / z 178\left[80 \%, \mathrm{M}^{+} ; t_{\mathrm{R}}\right.$ $=10.78 \mathrm{~min}] . \mathrm{HRMS}$ Calcd. for $\mathrm{C}_{12} \mathrm{H}_{15} \mathrm{~F}\left(\mathrm{M}+\mathrm{H}^{+}\right)$179.1237; Found: 179.1246.

Treatment of 86a $(E / Z, 95: 5,32 \mathrm{mg}, 0.12 \mathrm{mmol})$ with tert-butylzinc bromide $(0.5 \mathrm{M}, 0.48$ $\mathrm{mL}, 0.24 \mathrm{mmol})$ in the presence of $\mathrm{Pd}\left(\mathrm{Ph}_{3} \mathrm{P}\right)_{4}(5 \%$ molar $)$ as described in procedure I [ 24 
h, $65{ }^{\circ} \mathrm{C}$ ] gave $93 \mathbf{a}(60 \%)$ and $94^{131}(20 \%, 40 \%$ consumption of $86 a):{ }^{19} \mathrm{~F}$ NMR $\delta-109.47$ (d, $J=40.7 \mathrm{~Hz}, 0.60 \mathrm{~F}$ ), -127.95 (“dd", $J=28.6,14.6 \mathrm{~Hz}, 0.40 \mathrm{~F}$ ).

Treatment of $86 \mathbf{a}(E / Z, 95: 5,40 \mathrm{mg}, 0.16 \mathrm{mmol})$ with tert-butylzinc bromide $(0.5$ $\mathrm{M}, 0.6 \mathrm{~mL}, 0.32 \mathrm{mmol})$ in the presence of $\mathrm{Pd}_{2}(\mathrm{dba})_{3}(5 \%$ molar $)$ as described in procedure I [12 h, $50{ }^{\circ} \mathrm{C}$ ] gave $94^{131}$ (35 $\left.\mathrm{mg}, 45 \%\right)$ based on ${ }^{19} \mathrm{~F}$ NMR.

\section{Coupling with secondary alkylzinc bromides:}

Treatment of 86a $(E / Z, 95: 5 ; 18 \mathrm{mg}, 0.07 \mathrm{mmol})$ with $\mathrm{Pd}_{2}(\mathrm{dba})(5 \%$ molar $)$ and 1methylbutylzinc bromide $(0.5 \mathrm{M}, 0.29 \mathrm{~mL}, 0.14 \mathrm{mmol})$ as described in procedure I [3h, $\left.50{ }^{0} \mathrm{C}\right]$ gave a mixture of $\mathbf{9 3 b}(50 \%)$ and $94(12 \%)$ in addition to $Z$ - $\beta$-fluorostyrene ${ }^{136}$ (26\%): ${ }^{19} \mathrm{~F}$ NMR $\delta-109.34(\mathrm{dd}, J=40.2,22.9 \mathrm{~Hz}, 0.50 \mathrm{~F}, 93 \mathrm{~b}),-122.49$ (dd, $J=82.5$, $44.6 \mathrm{~Hz}, 0.26 \mathrm{~F}, Z$ - $\beta$-fluorostyrene), -127.95 (“dd”, $J=28.6,14.6 \mathrm{~Hz}, 0.24 \mathrm{~F}, 94)$ ) GC-MS for $\mathbf{9 3 b} / \mathbf{9 4}$ had $\mathrm{m} / z 192\left(65 \%, \mathrm{M}^{+} ; t_{\mathrm{R}}=14.08 \mathrm{~min} ; \mathbf{9 3 b}\right), 242\left(100 \%, \mathrm{M}^{+} ; \mathrm{t}_{\mathrm{R}}=21.46 \mathrm{~min}\right.$; 94)

Treatment $\left(18 \mathrm{~h}, 65{ }^{0} \mathrm{C}\right)$ of $86 \mathrm{a}(E / Z, 95: 5 ; 22 \mathrm{mg}, 0.088 \mathrm{mmol})$ with 1methylbutylzinc bromide $(0.5 \mathrm{M}, 0.35 \mathrm{~mL}, 0.17 \mathrm{mmol})$ in the presence of $\mathrm{Pd}\left(\mathrm{Ph}_{3} \mathrm{P}\right)_{4}(5 \%$ molar) gave 93d $\left[37 \% ;{ }^{19} \mathrm{~F}\right.$ NMR $\left.\delta-101.01(\mathrm{dt}, J=18.8,40.3 \mathrm{~Hz})\right], 94(19 \%)$ and $Z-\beta-$ fluorostyrene (4\%) as estimated based on the ${ }^{19} \mathrm{~F}$ NMR and GC-MS of the crude reaction mixture.

Treatment of 86a $(E / Z, 95: 5,50 \mathrm{mg}, 0.20 \mathrm{mmol})$ and 3-pentylzinc bromide $(0.5$ $\mathrm{M}, 0.60 \mathrm{~mL}, 0.30 \mathrm{mmol})$ in the presence of $\mathrm{Pd}\left(\mathrm{Ph}_{3} \mathrm{P}\right)_{4}(5 \%$ molar $)$ as described in procedure I gave inseparable mixture of $93 \mathbf{c}$ and $93 \mathbf{d}(30 / 70)$ : GC-MS $m / z 192\left(85 \%, \mathrm{M}^{+}\right.$; $\left.t_{\mathrm{R}}=11.67 \mathrm{~min}, \mathbf{9 3 c}\right), 192\left(60 \%, \mathrm{M}^{+} ; \mathrm{t}_{\mathrm{R}}=12.55 ; \mathbf{9 3 d}\right)$. HRMS (AP-ESI) Calcd. for $\mathrm{C}_{13} \mathrm{H}_{17} \mathrm{~F}\left(\mathrm{M}+\mathrm{Li}^{+}\right):$199.1474; Found: 199.1478 . 
(Z)-Ethyl 5-Chloro-6-phenyl-5-hexenoate (98a). Procedure J. 4-ethoxy-4oxobutylzinc bromide $(0.5 \mathrm{M}, 1.45 \mathrm{~mL}, 0.722 \mathrm{mmol})$ was added via syringe to a stirring solution of $96 \mathbf{a}^{125}(50 \mathrm{mg}, 0.29 \mathrm{mmol})$ in dried THF ( $\left.3 \mathrm{~mL}\right)$ containing $\mathrm{PdCl}_{2}$ (ddpf) (24 $\mathrm{mg}, 0.029 \mathrm{mmol}$ ) under $\mathrm{N}_{2}$. The resulting mixture was heated at $65{ }^{0} \mathrm{C}$ overnight. Volatiles were evaporated and the residue was partitioned $\left(\mathrm{NaHCO}_{3} / \mathrm{H}_{2} \mathrm{O} / \mathrm{EtOAc}\right)$. The organic layer was washed (brine), dried $\left(\mathrm{Na}_{2} \mathrm{SO}_{4}\right)$, evaporated, and chromatographed (hexane $\rightarrow 10 \%$ EtOAc/hexane) to give $98 \mathrm{a}(47 \mathrm{mg}, 65 \%)$ and $101 \mathrm{a}^{137}(14 \mathrm{mg}, 22 \%)$. Compound 98a had: ${ }^{1} \mathrm{H}$ NMR $\delta 1.16(\mathrm{t}, J=7.1 \mathrm{~Hz}, 3, \mathrm{OEt}$ ), 1.89 (quint, $J=7.1 \mathrm{~Hz}, 2$, H3), 2.27 (t, $J=7.4 \mathrm{~Hz}, 2, \mathrm{H} 4), 2.45$ (t, $J=7.1 \mathrm{~Hz}, 2, \mathrm{H} 2), 4.04$ (q, $J=7.1 \mathrm{~Hz}, 2$, OEt), $6.40(\mathrm{~s}, 1, \mathrm{H} 6), 7.15(\mathrm{t}, J=7.3 \mathrm{~Hz}, 2, \mathrm{Ph}), 7.25(\mathrm{t}, J=7.9 \mathrm{~Hz}, 1, \mathrm{Ph}), 7.45(\mathrm{~d}, J=7.4 \mathrm{~Hz}$, 2, Ph). ${ }^{13} \mathrm{C}$ NMR $\delta: 14.05\left(\mathrm{CH}_{3}, \mathrm{OEt}\right), 22.61(\mathrm{CH} 2, \mathrm{C} 3), 31.56(\mathrm{CH} 2, \mathrm{C} 2), 40.28(\mathrm{CH} 2$, C4), 60.34 (OEt, CH2), 125.25 (CH, C6), 127.55 (CH, Ph), 128.13 (CH, Ph), 128.98 (CH, Ph), 133.63 (C, C5), 134.97 (C, Ph), 174.10 (CO, C1). GC-MS m/z 252 (30\%, M $\left.\left[{ }^{35} \mathrm{Cl}\right] ; t_{\mathrm{R}}=20.00 \mathrm{~min}\right)$. HRMS (AP-ESI) Calcd for $\mathrm{C}_{14} \mathrm{H}_{17} \mathrm{ClO}_{2}\left(\mathrm{M}+\mathrm{H}^{+}\right): 253.0995$; Found: 253.0989 .

Analogous treatment $\left(65^{\circ} \mathrm{C}, 2 \mathrm{~h}\right)$ of $96 \mathrm{a}(50 \mathrm{mg}, 0.29 \mathrm{mmol})$ with 4-ethoxy-4oxobutylzinc bromide $(0.5 \mathrm{M}, 1.45 \mathrm{~mL}, 0.722 \mathrm{mmol})$ in dried THF (5 mL) in the presence of $\mathrm{PdCl}_{2}(\mathrm{dppb})(5 \%$ molar) gave 98a (39 mg, $53 \%$ ), 100a (26 mg, 27\%), $101 \mathbf{a}^{137}(10 \mathrm{mg}, 15 \%)$.

Analogous treatment $\left(65^{\circ} \mathrm{C}, 2 \mathrm{~h}\right)$ of $\mathbf{9 6 a}(50 \mathrm{mg}, 0.29 \mathrm{mmol})$ with 4-ethoxy-4oxobutylzinc bromide $(0.5 \mathrm{M}, 1.45 \mathrm{~mL}, 0.722 \mathrm{mmol})$ in dried THF (5 mL) in the presence of $\mathrm{Pd}\left(\mathrm{PPh}_{3}\right)_{4}(5 \%$ molar) gave only the dialkylated byproduct $100 \mathrm{a}(68 \%)$ and $101 \mathbf{a}^{137}(28 \%)$. 
(Z)-Ethyl 5-Chloro-6-(4-methoxyphenyl)-5-hexenoate (98b). Treatment $\left(50{ }^{\circ} \mathrm{C}\right.$ to $65{ }^{\circ} \mathrm{C}$, overnight) of $96 \mathbf{b}(41 \mathrm{mg}, 0.20 \mathrm{mmol}$ ) with 4-ethoxy-4-oxobutylzinc bromide $(0.5 \mathrm{M}, 2 \mathrm{~mL}, 1.01 \mathrm{mmol})$ in the presence of $\mathrm{PdCl}_{2}(\mathrm{dppf})(5 \%$ molar) and DPEPhos ( $3 \%$ molar) in dried benzene $(5 \mathrm{~mL})$ as described in procedure $\mathrm{J}$ gave $\mathbf{9 8 b}(Z)(39.5 \mathrm{mg}, 70 \%)$ and 100b (19 mg, $27 \%$ ). Compound 98b had: ${ }^{1} \mathrm{H}$ NMR $\delta 1.26(\mathrm{t}, J=7.1 \mathrm{~Hz}, 3, \mathrm{OEt})$, 2.01 (quint, $J=7.3 \mathrm{~Hz}, 2, \mathrm{H} 3$ ), 2.36 (t, $J=7.4 \mathrm{~Hz}, 2, \mathrm{H} 4), 2.52$ (t, $J=7.2 \mathrm{~Hz}, 2, \mathrm{H} 2$ ), $3.82(\mathrm{~s}, 3, \mathrm{OMe}), 4.13$ (q, $J=7.1 \mathrm{~Hz}, 2, \mathrm{OEt}), 6.43(\mathrm{~s}, 1, \mathrm{H} 6), 6.88$ (d, $J=8.8 \mathrm{~Hz}, 2, \mathrm{Ph})$, $7.57(\mathrm{~d}, J=8.7 \mathrm{~Hz}, 2, \mathrm{Ph}) .{ }^{13} \mathrm{C} \mathrm{NMR} \delta: 14.25\left(\mathrm{CH}_{3}, \mathrm{OEt}\right), 22.80\left(\mathrm{CH}_{2}, \mathrm{C} 3\right), 32.84\left(\mathrm{CH}_{2}\right.$, C2), $40.28\left(\mathrm{CH}_{2}, \mathrm{C} 4\right), 55.21(\mathrm{OMe}), 60.34\left(\mathrm{OEt}, \mathrm{CH}_{2}\right), 113.56(\mathrm{CH}, \mathrm{Ph}), 124.67(\mathrm{CH}$, C6), 127.55 (CH, Ph), 130.63 (CH, Ph), 131.63 (C5), $158.93(\mathrm{Ph}), 173.22$ (CO, C1). GCMS $m / z 282\left[25 \%, \mathrm{M}^{+}\left[{ }^{35} \mathrm{Cl}\right] ; t_{\mathrm{R}}=23.50 \mathrm{~min}\right]$

Analogous treatment of $\mathbf{9 6 \mathbf { b }}(35 \mathrm{mg}, 0.17 \mathrm{mmol})$ with 4-ethoxy-4-oxobutylzinc bromide $(0.5 \mathrm{M}, 0.57 \mathrm{~mL}, 0.28 \mathrm{mmol})$ in dried benzene $(5 \mathrm{~mL})$ in the presence of $\mathrm{PdCl}_{2}(\mathrm{dppb})(5 \%$ molar) and DPEPhos (3\%) as described in procedure $\mathrm{J}$ gave $\mathbf{9 8 \mathbf { b }}$ (30 $\mathrm{mg}, 63 \%), \mathbf{1 0 0 b}(17 \mathrm{mg}, 27 \%)$ and $\mathbf{1 0 1 b}(4 \mathrm{mg}, 10 \%)$.

Analogous treatment of $\mathbf{9 6 \mathbf { b }}(45 \mathrm{mg}, 0.22 \mathrm{mmol})$ with 4-ethoxy-4-oxobutylzinc bromide $(0.5 \mathrm{M}, 0.57 \mathrm{~mL}, 0.28 \mathrm{mmol})$ in dried benzene $(5 \mathrm{~mL})$ in the presence of $\mathrm{Pd}\left(\mathrm{PPh}_{3}\right)_{4}(5 \%$ molar $)$ and DPEPhos $(3 \%$ molar) as described in procedure $\mathrm{J}$ gave $\mathbf{9 8 b}$ (34 mg, 55\%), 100b (28 mg, 35\%) and 101b (5.5 mg, 10\%).

Analogous treatment of $96 \mathrm{c}(45 \mathrm{mg}, 0.24 \mathrm{mmol})$ with 4-ethoxy-4-oxobutylzinc bromide $(0.5 \mathrm{M}, 0.57 \mathrm{~mL}, 0.28 \mathrm{mmol})$ in dried benzene $(5 \mathrm{~mL})$ in the presence of $\mathrm{PdCl}_{2}(\mathrm{dppb})(5 \%$ molar) and DPEPhos (3\% molar ) as described in procedure $\mathrm{J}$ gave 100c (75 mg, 90\%) and 101c ( $5.5 \mathrm{mg}, 10 \%)$. 
Treatment of $97 \mathbf{a}(50 \mathrm{mg}, 0.19 \mathrm{mmol})$ with 4-ethoxy-4-oxobutylzinc bromide $(0.5$ $\mathrm{M}, 0.57 \mathrm{~mL}, 0.28 \mathrm{mmol})$ in dried THF $(5 \mathrm{~mL})$ in the presence of $\mathrm{PdCl}_{2}(\mathrm{dppf})(21 \mathrm{mg}$, $0.025 \mathrm{mmol})$ as described in procedure $\mathrm{J}$ gave $100 \mathrm{a}(29 \mathrm{mg}, 69 \%)$ and 101a (18mg, $28 \%)$.

Analogous treatment of $97 \mathbf{a}(50 \mathrm{mg}, 0.19 \mathrm{mmol})$ with 4-ethoxy-4-oxobutylzinc bromide $(0.5 \mathrm{M}, 0.57 \mathrm{~mL}, 0.28 \mathrm{mmol})$ in dried THF $(5 \mathrm{~mL})$ in the presence of $\mathrm{PdCl}_{2}(\mathrm{dppb})(5 \%$ molar $)$ as described in procedure $\mathrm{J}\left(65{ }^{\circ} \mathrm{C}\right.$, overnight $)$ gave 100a (47 $\mathrm{mg}, 75 \%)$ and 101a (10 mg, 24\%).

Analogous treatment of $97 \mathbf{a}(50 \mathrm{mg}, 0.19 \mathrm{mmol})$ with 4-ethoxy-4-oxobutylzinc bromide $(0.5 \mathrm{M}, 0.57 \mathrm{~mL}, 0.28 \mathrm{mmol})$ in dried THF $(5 \mathrm{~mL})$ in the presence of $\mathrm{Pd}\left(\mathrm{Ph}_{3} \mathrm{P}\right)_{4}$ ( $29 \mathrm{mg}, 0.025 \mathrm{mmol}$ ) gave 100a (38 mg, 60\%) and 101a (16 mg 38\%).

(Z)-Ethyl 5-Bromo-6-(4-methoxyphenyl)-5-hexenoate (99b). Treatment of 97b (40 mg, $0.13 \mathrm{mmol}$ ) with 4-ethoxy-4-oxobutylzinc bromide $(0.5 \mathrm{M}, 2 \mathrm{~mL}$ ) in the presence of $\mathrm{PdCl}_{2}(\mathrm{dppf})(5 \%$ molar) and DPEPhos ( $3 \%$ molar) in dried benzene $(5 \mathrm{~mL})$ as described in procedure $\mathrm{J}$ gave $99 \mathrm{~b}(Z)(20 \mathrm{mg}, 47 \%)$ and $100 \mathrm{~b}(13 \mathrm{mg}, 27 \%)$. Compound 99b had: 'H NMR $\delta 1.17$ (t, $J=7.1 \mathrm{~Hz}, 3, \mathrm{OEt}$ ), 1.92 (quint, $J=7.3 \mathrm{~Hz}, 2$, H3), 2.29 (t, $J=7.4 \mathrm{~Hz}, 2, \mathrm{H} 4), 2.57$ (t, $J=7.4 \mathrm{~Hz}, 2, \mathrm{H} 2), 3.74(\mathrm{~s}, 3, \mathrm{OMe}), 4.06$ (q, $J=$ $7.1 \mathrm{~Hz}, 2, \mathrm{OEt}), 6.61(\mathrm{~s}, 1, \mathrm{H} 6), 6.80(\mathrm{~d}, J=8.8 \mathrm{~Hz}, 2, \mathrm{Ph}), 7.47(\mathrm{~d}, J=8.7 \mathrm{~Hz}, 2, \mathrm{Ph})$. ${ }^{13} \mathrm{C}$ NMR $\delta: 14.26\left(\mathrm{CH}_{3}, \mathrm{OEt}\right), 23.49\left(\mathrm{CH}_{2}, \mathrm{C} 3\right), 32.72\left(\mathrm{CH}_{2}, \mathrm{C} 2\right), 42.34\left(\mathrm{CH}_{2}, \mathrm{C} 4\right)$, $55.26(\mathrm{OMe}), 60.39\left(\mathrm{OEt}, \mathrm{CH}_{2}\right), 113.47(\mathrm{CH}, \mathrm{Ph}), 124.54(\mathrm{CH}, \mathrm{C} 6), 127.83(\mathrm{CH}, \mathrm{Ph})$, $128.32(\mathrm{C} 5), 131.63(\mathrm{CH}, \mathrm{Ph}), 159.03(\mathrm{Ph}), 173.22(\mathrm{CO}, \mathrm{C} 1) . \mathrm{GC}-\mathrm{MS} \mathrm{m} / z 326[2 \%$, $\left.\mathrm{M}^{+}[79 \mathrm{Br}] ; t_{\mathrm{R}}=23.50 \mathrm{~min}\right]$. 
Analogous treatment of $\mathbf{9 7 b}(45 \mathrm{mg}, 0.15 \mathrm{mmol})$ with 4-ethoxy-4-oxobutylzinc bromide $(0.5 \mathrm{M}, 0.57 \mathrm{~mL}, 0.28 \mathrm{mmol})$ in dried benzene $(5 \mathrm{~mL})$ in the presence of $\mathrm{PdCl}_{2}(\mathrm{dppb})$ (5\% molar) and DPEPhos (3\%) as described in procedure $\mathrm{J}$ gave $100 \mathbf{b}$ (42 $\mathrm{mg}, 78 \%)$ and $\mathbf{1 0 1 b}(8 \mathrm{mg}, 21 \%)$.

Analogous treatment of $\mathbf{9 7 b}(45 \mathrm{mg}, 0.15 \mathrm{mmol})$ with 4-ethoxy-4-oxobutylzinc bromide $(0.5 \mathrm{M}, 0.57 \mathrm{~mL}, 0.28 \mathrm{mmol})$ in dried benzene $(5 \mathrm{~mL})$ in the presence of $\mathrm{Pd}\left(\mathrm{PPh}_{3}\right)_{4}(5 \%$ molar) and DPEPhos (3\%) as described in procedure $\mathrm{J}$ gave $99 \mathbf{b}$ (20 mg, 40\%), $100 \mathrm{~b}$ (32 mg, 59\%).

Treatment of $\mathbf{9 7 b}$ (45 mg, $0.15 \mathrm{mmol}$ ) with 4-ethoxy-4-oxobutylzinc bromide ( 0.5 $\mathrm{M}, 0.57 \mathrm{~mL}, 0.28 \mathrm{mmol})$ in dried benzene $(5 \mathrm{~mL})$ in the presence of $\mathrm{Pd}\left(\mathrm{PPh}_{3}\right)_{4}(5 \%$ molar) as described in procedure $\mathrm{J}$ gave only $\mathbf{1 0 0 b}(39 \mathrm{mg}, 72 \%)$ and $\mathbf{1 0 1 b}(9.6 \mathrm{mg}$, $26 \%)$.

Treatment of $97 \mathrm{c}(50 \mathrm{mg}, 0.18 \mathrm{mmol})$ with 4-ethoxy-4-oxobutylzinc bromide $(0.5$ $\mathrm{M}, 0.57 \mathrm{~mL}, 0.28 \mathrm{mmol})$ in dried benzene $(5 \mathrm{~mL})$ in the presence of $\mathrm{PdCl}_{2}(\mathrm{dppb})(5 \%$ molar) and DPEPhos (3\%) as described in procedure J gave 100c (17 mg, 27\%) and 101c (4 mg, 10\%).

Ethyl 6-phenyl-5-(3-ethoxycarbonylpropyl)hexenoate (100a). Compound 100a had: ${ }^{1} \mathrm{H}$ NMR $\delta 1.15(\mathrm{t}, J=7.1 \mathrm{~Hz}, 3, \mathrm{OEt}), 1.19(\mathrm{t}, J=7.1 \mathrm{~Hz}, 3, \mathrm{OEt}) 1.66-1.82(\mathrm{~m}, 4$, H3), 2.10-2.22 (m, 4, H4), 2.27 (t, $J=7.4 \mathrm{~Hz}, 4, \mathrm{H} 2), 3.98-4.09$ (m, 4, OEt), 6.25 (s, 1, H6), 7.08-7.25 (m, 5, Ph); ${ }^{13} \mathrm{C}$ NMR $\delta 14.56\left(\mathrm{CH}_{3}, \mathrm{OEt}\right), 14.62\left(\mathrm{CH}_{3}, \mathrm{OEt}\right), 23.69\left(\mathrm{CH}_{2}\right.$, C3), $23.77\left(\mathrm{CH}_{2}, \mathrm{C}^{\prime}\right), 30.08\left(\mathrm{CH}_{2}, \mathrm{C}^{\prime}{ }^{\prime}\right), 34.18\left(\mathrm{CH}_{2}, \mathrm{C} 2\right), 34.47\left(\mathrm{CH}_{2}, \mathrm{C}^{\prime}{ }^{\prime}\right), 36.50$ $\left(\mathrm{CH}_{2}, \mathrm{C} 4\right), 60.60\left(\mathrm{OEt}, \mathrm{CH}_{2}\right), 60.62\left(\mathrm{OEt}, \mathrm{CH}_{2}\right), 126.51(\mathrm{CH}, \mathrm{C} 6), 127.07$ ( $\left.\mathrm{CH}, \mathrm{Ph}\right)$, $128.98(\mathrm{CH}, \mathrm{Ph}), 129.0(\mathrm{CH}, \mathrm{Ph}), 138.47(\mathrm{CH}, \mathrm{Ph}), 141.45(\mathrm{C}, \mathrm{C} 5), 173.71(\mathrm{CO})$, 
173.91(CO); GC-MS $m / z 332\left[35 \%, \mathrm{M}^{+} ; t_{\mathrm{R}}=25.36 \mathrm{~min}\right]$. Anal. Calcd. for $\mathrm{C}_{20} \mathrm{H}_{28} \mathrm{FO}_{4}$ (332.20): C, 72.26; H, 8.49. Found: C, 71.92; H, 8.59.

Ethyl 6-(4-methoxyphenyl)-5-(3-ethoxycarbonylpropyl)hexenoate (100b).

Compound 100b had: 'H NMR $\delta: 1.20(\mathrm{t}, J=7.1 \mathrm{~Hz}, 3, \mathrm{OEt}), 1.26(\mathrm{t}, J=7.1 \mathrm{~Hz}, 3$, OEt), 1.77-1.85 (m, 4, H3), 2.18-2.28 (m, 4, H4), 2.36 (t, J= $7.4 \mathrm{~Hz}, 4, \mathrm{H} 2), 3.82$ (s, 3, OMe), 4.08-4.18 (m, 4, OEt), 6.27 (s, 1, H6), 6.85 (d, $J=8.7 \mathrm{~Hz}, \mathrm{Ph}), 7.12(\mathrm{~d}, J=8.4 \mathrm{~Hz}$, $\mathrm{Ph}) ;{ }^{13} \mathrm{C}$ NMR $\delta: 14.22\left(\mathrm{CH}_{3}, \mathrm{OEt}\right), 14.26\left(\mathrm{CH}_{3}, \mathrm{OEt}\right), 23.33\left(\mathrm{CH}_{2}, \mathrm{C} 3\right), 23.38\left(\mathrm{CH}_{2}\right.$, C3'), $29.65\left(\mathrm{CH}_{2}, \mathrm{C} 4\right), 33.82\left(\mathrm{CH}_{2}, \mathrm{C} 2\right), 34.13\left(\mathrm{CH}_{2}, \mathrm{C} 2{ }^{\prime}\right), 36.21\left(\mathrm{CH}_{2}, \mathrm{C} 4\right), 55.24$ $\left(\mathrm{OMe}, \mathrm{CH}_{3}\right) 60.28\left(\mathrm{OEt}, \mathrm{CH}_{2}\right), 60.62\left(\mathrm{OEt}, \mathrm{CH}_{2}\right), 113.56(\mathrm{CH}, \mathrm{Ph}), 126.13(\mathrm{CH}, \mathrm{C} 6)$, $129.72(\mathrm{CH}, \mathrm{Ph}), 130.62(\mathrm{Ph}), 139.78$ (C, C5), 157.91 (C, Ph) 173.45 (CO), 173.66 (CO); GC-MS $m / z 362\left[50 \%, \mathrm{M}^{+} ; t_{\mathrm{R}}=27.80 \mathrm{~min}\right]$.

Ethyl 6-phenyl-5-(3-ethoxycarbonylpropyl)heptenoate (100c). Compound 100c had: ${ }^{1} \mathrm{H}$ NMR $\delta: 1.12(\mathrm{t}, J=7.1 \mathrm{~Hz}, \mathrm{OEt}), 1.19(\mathrm{t}, J=7.1 \mathrm{~Hz}, \mathrm{OEt}), 1.51-1.56(\mathrm{~m}, 4$, H3), 1.51 (quint, $J=7.3 \mathrm{~Hz}, 2, \mathrm{H} 3$ ), 1.71 (quint, $\mathrm{J}=7.3 \mathrm{~Hz}, 2, \mathrm{H} 3$ '), 1.81 (t, $J=7.2 \mathrm{~Hz}$, 2, H4), 1.87 (s, 3, $\left.\mathrm{CH}_{3}\right), 2.00$ (t, $J=7.1 \mathrm{~Hz}, 2, \mathrm{H} 4$ '), 2.12 (t, $\left.J=7.1 \mathrm{~Hz}, 2, \mathrm{H} 2\right), 2.28$ (t, $J$ $\left.=7.1 \mathrm{~Hz}, 2, \mathrm{H} 2^{\prime}\right), 3.96(\mathrm{q}, J=7.2 \mathrm{~Hz}, 2, \mathrm{OEt}), 4.08(\mathrm{q}, J=7.2 \mathrm{~Hz}, 2, \mathrm{OEt}), 6.98-7.24(\mathrm{~m}$, 5, Ph). ${ }^{13} \mathrm{C}$ NMR $\delta: 14.19\left(\mathrm{CH}_{3}, \mathrm{OEt}\right), 14.28\left(\mathrm{CH}_{3}, \mathrm{OEt}\right), 21.13\left(\mathrm{CH}_{3}, \mathrm{C} 7\right), 23.67\left(\mathrm{CH}_{2}\right.$, C3), $23.91\left(\mathrm{CH}_{2}, \mathrm{C} 3\right.$ '), $30.19\left(\mathrm{CH}_{2}, \mathrm{C} 4\right), 31.95\left(\mathrm{CH}_{2}, \mathrm{C}^{\prime}\right), 34.11\left(\mathrm{CH}_{2}, \mathrm{C} 2\right), 34.14\left(\mathrm{CH}_{2}\right.$, C2), $60.15\left(\mathrm{CH}_{2}, \mathrm{OEt}\right), 60.31\left(\mathrm{CH}_{2}, \mathrm{OEt}\right), 125.95(\mathrm{C}, \mathrm{C} 6), 128.06(\mathrm{CH}, \mathrm{Ph}), 128.13(\mathrm{CH}$, Ph), 133.33 (C, C5), 133.68 (CH, Ph), 145.05 (C, Ph), 173.55 (C1, CO), 173.64 (C1, CO). GC-MS $m / z 346\left[50 \%, \mathrm{M}^{+} ; t_{\mathrm{R}}=25.15 \mathrm{~min}\right]$. 


\section{CONCLUSION}

$S$-Adenosyl-L-homocysteine (AdoHcy) hydrolase is an intracellular enzyme which is crucial for the maintenance of biomethylation processes. The standard mechanistic sequence involves the oxidation of AdoHcy at C3' ("oxidative activity") followed by elimination of L-homocysteine, Michael type addition of water ("hydrolytic activity") and reduction of the 3'-keto adenosine intermediate to yield adenosine. The 6'halo(homovinyl)adenosine analogues were found to be concentration and time dependent inactivators of AdoHcy hydrolase. They underwent hydration of the 5',6' double bond by the "hydrolytic activity" of the enzyme. To probe further "hydrolytic activity" of AdoHcy hydrolase, analogues of AdoHcy with the carbon-5' and sulfur atoms replaced by a vinyl or halovinyl unit were designed and synthesized. Also, L-adenosine, the enantiomer of the natural substrate, was synthesized in order to examine the possibility of whether Ladenosine can act as (un)likely substrate and/or inhibitor of AdoHcy hydrolase.

The first targets were L-adenosine and its 5'-aldehyde oxime. Their synthesis started from L-xylose utilizing literature protocols. L-adenosine and its 5'-aldehyde oxime were evaluated for their ability to inhibit the activity of recombinant human placental AdoHcy hydrolase by incubating the enzyme with them at $200 \mu \mathrm{M}$ for $20 \mathrm{~min}$ at $37{ }^{\circ} \mathrm{C}$. The AdoHcy hydrolase activity was determined by assaying the enzyme's ability to catalyze the conversion of Ado and Hcy to AdoHcy. Under these conditions, L-adenosine and its 5'-aledehyde oxime were found to be inactive as inhibitors of the AdoHcy hydrolase. Docking calculations showed that binding of L-Ado is not as specific as that of D-Ado for the AdoHcy hydrolase and that the binding energy of the D-Ado/enzyme complex is lower than that of the L-Ado/enzyme complex. These results 
might explain why L-Ado and its analogues are inactive as inhibitors of AdoHcy hydrolase.

The second targets were AdoHcy analogues in which the sulfur and $\mathrm{C5}^{\prime}$ ' atoms in the $S$-adenosyl-L-homocysteine were replaced by the vinyl or halovinyl unit. These analogues should form a "stable" complex with the enzyme, which would interact with the enzyme to identify the major binding groups of the active site of AdoHcy that interact with Hcy moiety and participates in elimination and hydrolytic activity steps. These targets were synthesized employing a metathesis approach to construct a new C5'-C6' double bond and Negishi Pd-catalyzed cross-coupling to build a new C6'-C7' single bond.

Cross-metathesis of the protected 5'-deoxy-5'-methyleneadenosine analogue with racemic 2-amino-5-hexenoate (unnatural aminoacid) in the presence of HoveydaGrubb's catalyst followed by standard deprotections afforded $5^{\prime} E$ isomer of the inseparable mixture of $9^{\prime} R / S$ diastereomers. Metathesis of the chiral homoallylglycine [(2S)-amino-5-hexenoate $] \quad$ with 6-N-dibenzoyl protected 5'-deoxy-5'methyleneadenosine precursor afforded the AdoHcy analogue with established stereochemistry $\left(5^{\prime} E, 9^{\prime} S\right)$. Contrary to products obtained from racemic homoallylglycine, the ${ }^{13} \mathrm{C}$ NMR spectra for products obtained from chiral homoallylglycine showed only a single set of peaks. ${ }^{1} \mathrm{H}$ NMR also showed some spectral differences especially for $\mathrm{H} 2$ and $\mathrm{H} 8$ from the adenine base. The 5'-bromovinyl analogue was synthesized using the bromination-dehydrobromination strategy with pyridinium tribromide and DBU. 
Since literature reports on the Pd-catalyzed monoalkylation of dihaloalkenes $\left(\mathrm{Csp}^{2}-\mathrm{Csp}^{3}\right.$ coupling) were scarce, we undertook model studies on Pd-catalyzed crosscoupling reactions between vinyl dihalides and alkyl organometallics. A series of 1fluoro-1-haloalkenes was chosen as precursors to study Pd-catalyzed Negishi coupling with alkylzincs. It was found that 1-fluoro-1-haloalkenes underwent Pd-catalyzed Negishi cross-couplings with primary alkylzinc bromides to give multisubstituted fluoroalkenes. The alkylation was trans-selective giving pure Z-fluoroalkenes in most cases. The highest yields were obtained with $\mathrm{Pd}_{2}(\mathrm{dba})_{3}$ and $\mathrm{PdCl}_{2}(\mathrm{dppb})$ catalysts but the best stereochemical outcome was observed with less reactive $\mathrm{Pd}\left(\mathrm{PPh}_{3}\right)_{4}$. The tertiary alkylzincs also produced desired fluoroalkenes. Coupling of $\beta, \beta$-dichlorostyrene and $\beta, \beta$-dibromostyrene with alkylzinc reagents afforded the monohalo substituted olefins, but addition of DPEPhos ligands was found to be critical.

In summary, we have synthesized AdoHcy analogues in which the sulfur and C5' atoms in the $S$-adenosyl-L-homocysteine were replaced by the vinyl or halovinyl unit using a metathesis approach. We have also developed Pd-catalyzed Negishi crosscoupling of 1-fluoro-1-(iodo, or bromo, or chloro)alkenes with alkylzincs, thus providing stereoselective access to the internal fluoroalkenes. 
Figure 11. List of chemical structures for chemicals

MFSTA: $N$-Methyl- $N$-(trimethylsilyl)trifluoroacetamide<smiles>CN(C)C(=O)C(F)(F)F</smiles>

$\mathrm{BzCl}$ : benzoyl chloride<smiles>O=C(Cl)c1ccccc1</smiles>

DCC: dicyclohexylcarbodiimide<smiles>C(=NC1CCCCC1)NC1CCCCC1</smiles>

dppb: 1,4-bis(diphenylphosphino)butane<smiles>c1ccc(P(CCCP(c2ccccc2)c2ccccc2)c2ccccc2)cc1</smiles>

$(\mathrm{tBuO})_{2} \mathrm{CO}$ : di-t -butylcarbonate<smiles>CC(C)(C)OC(=O)OC(C)(C)C</smiles>

DBU: 1,8-diazabicyclo[5.4.0]undec-7-ene<smiles>C1CCC2=NCCCN2CC1</smiles>

dpephos:bis(o-diphenylphosphanyl)phenylether<smiles>c1ccc(P(c2ccccc2)c2ccccc2Oc2ccccc2P(c2ccccc2)c2ccccc2)cc1</smiles>

dba: dibenzylideneacetone<smiles>O=C(/C=C/c1ccccc1)/C=C/c1ccccc1</smiles>

NBS: $N$-bromosuccinimide<smiles>O=C1CCC(=O)N1Br</smiles> 
NIS: $N$-iodosuccinimide<smiles>O=C1CCC(=O)N1I</smiles>

THF: tetrahydrofuran<smiles>C1CCOC1</smiles>

DMSO: dimethyl sulfoxide

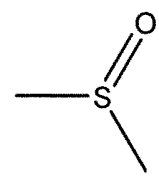

$t \mathrm{BuPh}_{2} \mathrm{SiCl}$ : tert-butylchlorodiphenylsilane<smiles>CC(C)(C)[Si](Cl)(c1ccccc1)c1ccccc1</smiles>

$\mathrm{Ac}_{2} \mathrm{O}$ : Acetic anhydride<smiles>CC(=O)OC(C)=O</smiles>

triethyl orthoformate

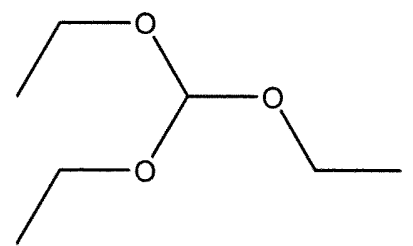

TMSOTf: trimethylsilyl trifluoromethane sulfonate p-toluenesulfonic acid<smiles>C[Si](C)(C)OS(=O)(=O)C(F)(F)F</smiles>

TFA: trifluoroacetic acid

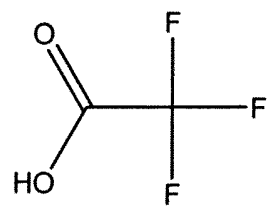<smiles>Cc1ccc(S(=O)(=O)O)cc1</smiles>

Imidazole<smiles>c1c[nH]cn1</smiles>

Pyr: pyridine<smiles>c1ccncc1</smiles> 


\section{REFERENCES}

1. Cantoni, G. L.; Chiang, P. K., In Natural Sulfur Compounds. Novel Biochemical and Structural Aspects (Cavallini, D.; Gaulle, G. E.; Zappie, V., eds.), Plenum Press, New York, 1980, 67-80.

2. Borchardt, R. T. J. Med. Chem. 1980, 23, 347-357

3. Biological Methylation and Drug Design; Borchardt, R. T.; Creveling, C. R.; Ueland, P. M., Eds.; Humana Press: Clifton, 1986.

4. Ueland, P. M. Pharmacol. Rev., 1982, 34, 223-253.

5. De la Haba, G.; Cantoni, G. L. J. Biol. Chem. 1959, 234, 603.

6. (a) Wolfe, M. S.; Borchardt, R. T. J. Med. Chem., 1991, 34, 1521-1530. (b) Yuan, C. S.; Liu, S.;Wnuk, S. F.; Robins, M. J.; Borchardt, R. T. In Advances in Antiviral Drug Design; Erik DeClercq, Ed.; JAI Press: Greenwich, CT, 1996, Vol.2, 41-88.

7. (a) Ueland, P. M.; Refsum, H. J. Lab. Clin. Med., 1989, 114, 473-501. (b) Chen, P.; Poddar, R.; Tipa, E. V.; Dibello, P. M.; Moravec, C. D.; Robinson, K.; Green, R.; Krugger, W. D.; Garrow, T. A.; Jacobsen, D. W. Advan. Enzyme Regul., 1999, 39, 93-109.

8. (a) Malinow, M. R. Clin. Chem., 1995, 41, 173-176. (b) Refsum, H.; Ueland, P.; Nygard, O.; Vollset, S.E. Annu. Rev. Med., 1998, 49, 31-62. (c) Langman, L. J. Cole, D. E.C. Crit. Rev. Clin. Lab. Sci., 1999, 36, 365-406.

9. Yuan, C. S.; Saso, Y.; Lazarides, E.; Borchardt, R. T.; Robins, M. J. Exp. Opin. Ther. Patents, 1999, 9, 1197-1206.

10. Bethin, K. E.; Cimato, T. R.; Ettinger, M. J. J. Biol. Chem. 1995, 270, 2070320711.

11. Bethin, K. E.; Petrovic, N.; Etiinger, M. J. J. Biol. Chem. 1995, 270, 2069820702.

12. Yuan, C. S.; Liu, S.; Wnuk, S. F.; Robins, M. J.; Borchardt, R. T. Nucleosides Nucleotides 1995, 14, 439-447. (b) Liu, S.; Wolfe, M. S.; Borchardt, R. T. Antiviral Res. 1992, 19, 247-265.

13. De Clercq, E. Biochem. Pharmacol. 1987, 36, 2567-2575; (b) De Clercq, E. Nucleosides Nucleotides, 1998, 17, 625-634; (c) Cools, M.; De Clercq, E. Biochem. Pharmacol. 1989, 38, 1061-1067. 
14. Daelemans, D.; Este, J. A.; Witvrouw, M.; Pannecouque, C.; Jonckheere, H.; Aquaro, S.; Perno, C. F.; De Clercq, E.; VanDamme, A. M. Mol. Pharm. 1997, 52, 1157-1163.

15. Masuta, C.; Tanaka, H.; Uehara, K.; Kuwata, S.; Koiwai, A.; Noma, M. Proc. Natl. Acad. Sci. USA 1995, 92, 6117-6121.

16. (a) Bitonti, A. J.; Baumann, J.; Varvi, T.; McCarthy, J.R.; McCan, P. P.Biochem. Pharmcol. 1990, 40, 601-606; (b) Henderson, D. M.; Hanson, S.; Allen, T.; Wilson, K.; Coulter-Karis, D. E.; Greenberg, M.L.; Hershfield, M. S.; Ullman, B. Mol. Biochem. Parasitol. 1992, 53, 169-184.

17. Wools, J. A.; Frondorf, K. A.; Esser, R. E. J. Immunol. 1993, 151, 526-234.

18. (a) Wools, J. A.; Frondorf, K. A.; Babcock, G. E.; Stripp, S. A.; Bowlin, T. L. Cell Immuniol. 1993, 149, 402-408. (b) Wolos, J. A.; Frondorf, K. A.; Davis, G. F.; Jarvi, E. T.; McCarthy, J.R.; Bowlin, T. L. J. Immunol. 1993, 150, 3264-3273.

19. De Clercq, E.; Cools, M.; Balzarini, J.; Marquez, V. E.; Borcherding, D. R.; Borchardt, R. T.; Drach, J. C.; Kitakota, S.; Konno, T. Antimicrob. Agents Chemother. 1989, 33, 1291.

20. (a) Palmer, J.L.; Abeles, R. H. J. Biol. Chem. 1976, 251, 5817-5819; (b) Palmer, J. L.; Abeles, R. H. J. Biol. Chem. 1979, 254, 1217-1226.

21. Sinhababu, A. K.; Bartel, R. L.; Pochopin, N.; Borchardt, R. T.; J. Am. Chem. Soc., 1985, 107, 1628-1632.

22. Parry, R.; Askonas, L. J. J. Am. Chem. Soc., 1985, 107, 1417-1418.

23. (a) Porter, D. J. T. J. Biol. Chem., 1993, 268, 66-73. (b) Porter, D. J. T.; Boyd, F. L. J. Biol. Chem. 1992, 267, 3205-3213.

24. Vederas, J. C.; Floss, H. G. Acc. Chem. Res. 1980, 13, 455-463.

25. Yuan, C. S.; Yeh, J.; Liu, S.; Borchardt, R. T. J. Biol. Chem., 1993, 268, 1703017037.

26. (a) Yuan, C. S.; Saso, Y.; Lazarides, E.; Borchardt, R. T.; Robins, M. J. Exp. Opin.Ther. Patents, 1999, 9, 1197-1206; (b) Yin, D.;Yang, X.; Borchardt, R. T. In Biomedical Chemsitry: Applying Principles to the Understanding and Tretament of Diseases; Paul F. Torrence, Ed.;John Wiley \& Sons: NY, 2000, 41-77.

27. Turner, M. A.; Yuan, C. S.; Borchardt, R. T.; Hershfield, M. S.; Smith, G. D.; Howell, P. L. Nature Struct. Biol. Chem. 1998, 5, 369-376. 
28. Hu, Y,; Komoto, J.; Huang, Y.; Gomi, T.; Ogawa, H.; Takata, Y.; Fujioka, M.; Takusagawa, F. Biochemistry, 1999, 38, 8323-8333.

29. Keller, B. T.; Borchardt, R. T. In Antiviral Drug Development, De Clercq, E.; Walker, R. T., eds. 1988,123-138, Plenium Publishing Corp., NY.

30. Guillerm, G.; Muzard, M.; Glapski, S. P.; De Clercq, E. J. Med. Chem. 2006, 49, 1223-1226.

31. (a) McCarthy, J.R.; Jarvi, E. T., Matthews, D. P., Edwards, M. L., Prakash, N. J.; Bowlin, T. L., Mehdi, S., Sunkara, P. S., Bey, P. J. Am. Chem. Soc., 1989, 111,1127-1128. (b) Mehdi, S.; Jarvi, E.T.; Koehl, J.R.; McCarthy, J.R.; Bey, P. J. Enzyme Inhibition, 1990, 4, 1-13. (c) Jarvi, E. T.; McCarthy, J. R.; Mehdi, S.; Matthews, D. P.; Edwards, M. L.; Prakash, N. J.; Bowlin, T.L.; Sunkara, P.S.; Bey, P. J. Med. Chem. 1991, 34, 647-656.

32. Liu, S.; Wnuk, S. F.; Yuan, C. S.; Robins, M. J.; Borchardt, R. T. J. Med. Chem. 1993, 36, 883-887.

33. Robins, M. J.; Wnuk, S. F.; Mullah, K. B.; Dalley, N. K.; Borchardt, R. T.; Lee, Y.; Yuan, C. S. In Nucleosides as Antitumor and Antiviral Agents; Chung K. Chu, David C. Baker, Eds.; Plenum Press: New York, 1993, 115-126.

34. Wnuk, S. F.; Dalley, N. K.; Robins, M. J. J.Org. Chem., 1993, 58, 111-117.

35. Wnuk, S. F.; Yuan, C. S.; Borchardt, R. T.; Balzarini, J.; De Clercq, E.; Robins, M. J. J. Med. Chem., 1994, 37, 3579-3587.

36. (a)Yuan, C. S.; Liu, S.; Wnuk, S. F.; Robins, M. J.; Borchardt, R.T.; Biochemistry, 1994, 33, 3758-3765. Yuan, C. S.; (b) Wnuk, S. F.; Liu, S.; Robins, M. J.; Borchardt, R.T.; Biochemistry, 1994, 33, 12305-12311.

37. Wnuk, S. F.; Robins, M. J.; Can. J. Chem., 1991, 69, 334-338.

38. Tius, M. A.; Kawakami, J. K. Synlett, 1993, 207-208.

39. Wnuk, S. F.; Yuan, C. S.; Borchardt, R.T.; Robins, M. J. Nucleosides Nucleotides, 1998, 17, 99- 113.

40. (a) Liu, S.; Wolfe, M. S.; Yuan, C. S.; Ali, M. S.; Borchardt, R. T. Bioorg. Med. Chem. Lett., 1992, 2, 1741-1744. (b) Liu, S.; Yuan, C. S.; Borchardt, R. T. J. Med. Chem., 1996, 39, 2347-2353.

41. Robins, M. J.; Neschadimenko, V.; Ro, B. O.; Yuan, C. S.; Borchardt, R.T.; Wnuk, S. F. J. Org. Chem. 1998, 63, 1205-1211. 
42. Wnuk, S. F.; Mao, Y.; Yuan, C. S.; Borchardt, R. T.; Andrei, G.; Balzarini, J.; De Clercq, E.; Robins, M. J. J. Med. Chem. 1998, 41, 3078-3083.

43. Yuan, C. S.; Wnuk, S. F.; Robins, M. J.; Borchardt, R. T.; J. Biol. Chem. 1998, 273, 18191- 18197.

44. (a) Grubbs, R. H.; Pine, S. H. in Comprehensive Organic Synthesis, Trost, B. M.; Fleming, I.; Paquette, L. A. Eds.; Pergamon: NY, 1991, vol. 5, chapter 9.3. (b) Ivin, K. J.; Mol, J. C. Olefin Metathesis and Metathesis Polymerization, Academic Press, San Diego, 1997, 496.

45. Grubbs, R. H.; Chang, S. Tetrahedron, 1998, 4413-4450.

46. Nicolau, K.C.; Bulger, P. G.; Sarlah, D. Angew. Chem. Inl. Ed., 2005, 44, 44904527.

47. (a) Nicolau, K.C.; Snyder, S. A.; Classics in Total Synthesis II, Wiley-VCH, Weinheim, 2003, 166-172. (b) Trnka, T.M.; Grubbs, R. H. Acc. Chem. Res. 2001, 34, 18-29.

48. Herisson, J.L.; Chauvin, Y. Macromol. Chem. 1971, 141, 161-176.

49. Casey, C. P.; Burkhardt, T. J. J. Am. Chem. Soc. 1974, 96, 7808-7809.

50. Katz, T. J.; McGinnis, J. J. Am. Chem. Soc 1975, 97, 1592-1594.

51. Grubbs, R. H.; Burk, P.L.; Carr, D. D. J. Am. Chem. Soc. 1975, 97, 3265-3267. Grubbs, R. H.; Carr, D. D.; Hoppin, C.; Buurk, P.L.; J. Am. Chem. Soc 1976, 98 , 3478-3483.

52. Schrock, R. R.; Murdzek, J. S.; Bazan, G.C.; Robbins, J.; DiMare, M.; O'Regan, M. J. Am. Chem. Soc. 1990, 112, 3875-3886.

53. McGinnis, J.; Katz, T.J.; Hurwitz, S. J. Am. Chem. Soc. 1976, 98, 605-606.

54. Toreki, R.; Schrock, R. R. J. Am. Chem. Soc. 1990, 112, 2448-2449.

55. Nguyen, S. T.; Johnson, L. K.; Grubbs, R. H.; Ziller, J. W. J. Am. Chem. Soc. 1992, 114, 3974- 3975.

56. Grubbs, R. H. J. Macromolec. Sci. - Pure Appl. Chem. 1994, A31, 1829-1833.

57. Randl, S.; Gessler, S; Wakamatsu, H.; Blechert, S. Synlett, 2001, 430. 
58. (a) Amblard, F.; Nolan, S. P.; Agrofoglio, L. A. Tetrahedron, 2005, 61, 70677080. (b) Amblard, F.; Nolan, S. P.; Gillaizeau, I.; Agrofoglio, L. A. Tetrahedron, 2003, 44, 9177-9180.

59. Agrofoglio, L. A.; Nolan, S. P.; Current Topics in Medicinal Chemistry, 2005, 5, 1541-1558.

60. Crimmins, M.T.; King, B. W. J.Org. Chem. 1996, 61, 4192.

61. Kuang, R.; Ganguly, A. K.; Chan, T. M.; Pramanik, B. N.; Blythin, D. J.; McPhail, A. T.; Saksena, A. K. Tetrahedron Lett. 2000, 41, 9575.

62. Borchardt, R. T.; Keller, B.; Patel-Thrombe, U. J. Biol. Chem. 1984, 259, 43534358.

63. (a) Gillaizeau, I.; Charamon, S.; Agrofolio, L.A. Tetrahedron Lett. 2001, 42, 8817-8819. (b) Agrofolio, L.A.; Amblard, F.; Nolan, S. P.; Charamon, S.; Gillaizeau, I.; Zevaco, T. A.; Guenot, P. Tetrahedron, 2004, 60, 8397-8404.

64. Jin, Y. H.; Liu, P.; Wang, J.; Baker, R.; Huggins, J.; Chu, C. K. J. Org. Chem. 2003, 68, 9012-9018.

65. Houston, D. M.; Matuszewska, B.; Borchardt, R. T. J. Med. Chem. 1985, 28, 478482.

66. Houston, D. M.; Dolence, E. K.; Keller, B. T.; Patel-Thrombe, U. ; Borchardt, R. T. J. Med. Chem. 1985, 28, 471-477.

67. Hasobe, M.; Liang, H.; Ault-Riche, D. B.; Borcherding, D. R.; Wolfe, M. S.; Borchardt, R. T.; Antiviral Chem. \& Chemother. 1993, 4, 245-248.

68. Bestmann, H. J.; Roth, D. Synlett, 1990, 751-753.

69. Moon, H. R.; Choi, W. J.; Kim, H. O.; Jeong, L. S. Tetrahedron: Asymmetry, 13, 2002, 1189-1193.

70. Furstner, A. Angew. Chem. Inl. Ed. 2000, 39, 3012-3043.

71. (a) Metal-Catalyzed Cross-Coupling Reactions; de Meijere, A., Diederich, F., Eds.; Wiley-VCH: Weinheim, Germany, 2004. (b) Topics in Current Chemistry; Miyaura, N., Ed.; Springer-Verlag: NY, 2002, vol. 219.

72. Negishi, E.-I.; Hu, Q.; Huang, Z.; Qian, M.; Wang, G. Aldrichim. Acta 2005, 38, 71-88. 
73. (a) Negishi, E. -I.; Liu, F. In Metal-Catalyzed Cross-Coupling Reactions; Diederich, F., Stang, P. J., Eds.; Wiley-VCH: Weinheim, Germany, 1998; Chapter 1, pp 1-47. (b) Dai, C.; Fu, G. C. J. Am. Chem. Soc. 2001, 123, 2719-2724.

74. (a) Zeng, X.; Hu, Q.; Quian, M.; Negishi, E. -I. J. Am. Chem. Soc. 2003, 125, 13636-13637. (b) ) Zeng, X.; Quian, M.; Hu, Q.; Negishi, E. -I. Angew. Chem., Int. Ed. 2004, 43, 2259-2263. (c) Minato, A. J. Org. Chem. 1991, 56, 4052-4056. (d) Negishi, E. -I.; Shi, J. C.; Zeng, X. Tetrahedron 2005, 61, 9886-9895. (e) Shi, J.-C.; Zeng, X.; Negishi, E. I. Org. Lett. 2003, 5, 1825-1828.

75. Lei, X.; Dutheuil, G.; Pannecoucke, X.; Quirion, J.-C. Org. Lett 2004, 6, 21012104.

76. (a) Minato, A.; Suzuki, K.; Tamao, K. J. Am. Chem. Soc. 1987, 109, 1257-1258.

(b) Tan, Z.; Negishi, E.-I. Angew. Chem. Int. Ed. 2006, 45, 762-765.

77. Baba, S.; Negishi, E. J. Am. Chem. Soc. 1976, 98, 6729-6731.

78. Negishi, E.; Baba, S. J. Chem. Soc., Chem. Commun. 1976, 596-597.

79. King, A. O., Okukada, N.; Negishi, E. J. Chem. Soc., Chem. Commun. 1977, $683-$ 684.

80. Negishi, E.; King, A.; Okukada, N. J. Org. Chem. 1977, 42, 1821-1823.

81. Negishi, E. Aspects Mech. Organomet. Chem., [Proc. Symp.] (ed. Brewster, J. H.), 285-317 (Plenum NY, 1978).

82. Erdik, E. Tetrahedron 1987, 43, 2203-2212.

83. Zhu, L.; Wehmeyer, R. M.; Rieke, R. D. J. Org. Chem. 1991, 56, 1445-1453.

84. Miyaura, N.; Suzuki, A. Chem. Rev. 1995, 95, 2457-2483.

85. Negishi, E. Handbook of Organopalladium Chemistry for Organic Synthesis, 1, 229-247, John Wiley \& Sons Inc., NY, 2002.

86. Sammakia, T.; Stangeland, E. L.; Whitcomb, M. C. Org. Lett., 2002, 4, 23852388 .

87. Negishi, E.-I.; Liou, S. Y.; Xu, C.; Huo, S. Org. Lett. 2002, 4, 261.

88. Zhou, J.; Fu, G. C. J. Am. Chem. Soc. 2003, 125, 12527.

89. Wiskur, S. L.; Korte, A.; Fu, G. C. J. Am. Chem. Soc. 2004, 126, 82. 
90. Chemler, S. R.; Trauner, D.; Danishefsky, S. J. Angew. Chem. Int. Ed. 2001, 40, 4544.

91. (a) Dang, H. P.; Linstrumelle, G. Tetrahedron Lett. 1978, 19, 191. (b) Hayashi, T.; Konishi, M.; Kumada, M. Tetrahedron Lett. 1979, 20, 1871. (c) Hayashi, T.; Konishi, M.; Yokota, K.; Kumada, M. Chem. Lett. 1980, 767.

92. (a) Smith, A. B., Qiu, Y.; Jones, D. R.; Kobayashi, K. J. Am. Chem. Soc. 1995, 117, 12011. (b) Smith, A. B.; Beauchamp, T. J. ; LaMarche, M. J.; Kaufman, M. D.; Qiu, Y.; Arimato, H.; Jones, D. R.; Kobayashi, K. J. J. Am. Chem. Soc. 2000, 122, 8654. (c) Paterson, I.; Florence, G. J. Eur. J. Org. Chem. 2003, 2193.

93. Langille, N.F.; Panek, J. S. Org. Lett. 2004, 6, 3203.

94. Novak, T.; Tan, Z.; Liang, B.; Negishi, E.-I. J. Am. Chem. Soc. 2005, 127, 2838.

95. Hu, T.; Takenaka, N.; Panek, J. S. J. Am. Chem. Soc. 2002, 124, 12806.

96. Tan, Z.; Negishi, E. -I. Angew. Chem. Int. Ed. 2004, 43, 2911.

97. (a) Grushin, V. V.; Alper, H. Chem. Rev. 1994, 94, 1047-1062. (b) Grushin, V. V.; Alper, H. In Activation of Unreactive Bonds and Organic Synthesis; Murai, S., Ed.; Springer-Verlag: Berlin, 1999, 193-226.

98. Shi, J.; Negishi, E.-I. J. Organomet. Chem. 2003, 687, 518.

99. Panek, J. S.; Hu, T. J. Org. Chem. 1997, 62, 4914.

100. (a) Roush, W. R.; Moriarty, K. J.; Brown, B. B.; Tetrahedron Lett. 1990, 31, 6509. (b) Roush, W. R.; Koyama, K.; Martine, M. L.; Moriarty, K. J. J. Am. Chem. Soc. 1996, 118, 7502. (c) Ogasawara, M.; Ikeda, H.; Hayshi, T. Angew. Chem. Int. Ed. 2000, 39, 1042.

101. Arefolov, A.; Panek, J. S. J. Am. Chem. Soc. 2005, 127, 5596.

102. (a) Wipf, P.; Lim, S. J. Am. Chem. Soc. 1995, 117, 558. (b) Williams, D. R.; Brooks, D. A.; Berliner, M. A. J. Am. Chem. Soc. 1999, 121, 4924.

103. Moyround, E.; Strazewski, P. Tetrahedron 1999, 55, 1277-1284.

104. (a)Vorbruggen H.; Krolikiewicz K.; Bennua B.; Chem. Ber. 1981, 114, 12341255. (b)Vorbruggen H.; Hofle G. Chem. Ber. 1981, 114, 1256-1268. (c) Vorbruggen H.; Acta Biochem. Polon. 1996, 43, 25-36.

105. Wnuk, S. F.; Yuan, C. S.; Borchardt, R. T.; Balzarini, J.; De Clercq E.; Robins, M. J. J. Med. Chem. 1997, 40, 1608-1618. 
106. (a) Wang, M; Zhang, J.; Andrei, D.; Kuczera, K.; Borchardt, R.T.; Wnuk, S.F. J. Med. Chem. 2005, 48, 3649-3653. (b) Wang, J. F.; Yang, X. D.; Zhang, L. R.; Yang, Z. J.; Zhang, L. H. Tetrahedron 2004, 38, 8535- 8546.

107. (a) Goodsell, D. M.; Olson, A. J. Proteins 1990, 8, 195-202. (b) Morris, G. M.; Goodsell, D. S.; Huey, R.; Olson, A. J. J. Comput. -Aided Mol. Des. 1996, 10, 293-304. (c) Morris, G. M.; Goodsell, D. S.; Halliday, R. S.; Huey, R.; Hart, W. E.; Belew, R. K.; Olson, A. J. J. Comput. Chem. 1998, 19, 1639-1662.

108. Huang, H.; Yuan, C. S.; Wnuk, S. F.; Robins, M. J.; Borchardt, R. T. Arch. Biochem. Biophys. 1997, 343, 109-117.

109. O’Donell, M. J.; Wojciechowski, K.; Synthesis 1984, 313-315.

110. O'Donell, M. J.; Polt, R. L. J. Org. Chem. 1982, 47, 2663-2666.

111. (a) Garber, S. B.; Kingsbury, J. S.; Gray, B. L.; Hoveyda, A. H. J. Am. Chem. Soc. 2000, 122, 8168-8179. (b) Gessler, S.; Randl, S.; Blecheret, S. Tetrahedron Lett. 2000, 41, 9973-9976.(c) Andrei, D.; Wnuk, S. F. Org. Lett. 2006, 8, 5093-5096.

112. Biagini, S. C. G.; Gibson, S. E.; Keen, S. P. J. Chem. Soc., Perkin Trans. 1998, 1, 2485-2499.

113. (a) Dunn, M. J.; Jackson, R. F. W.; Pietrusza, J.; Turner, D. J. Org. Chem. 1995, 60, 2210-2215. (b) Waelchli, R.; Beerli, C.; Meigel, H.; Revesz, L. Bioorg. Med. Chem. Lett. 1997, 7, 2831-2836. (c) Lohr, B.; Orlich, S.; Kunz, H. Synlett, 1999, 1139-1141.

114. Schricker, B.; Thirring, K.; Berner, H. Bioorg. Med. Chem. Lett. 1992, 2, 387390.

115. Dale, J. A.; Dull, D. L.; Mosher, H. S. J. Org. Chem. 1969, 34, 2543.

116. Tamelen, E. E.; Seiler, M. P.; Wierenga, W. J. Am. Chem. Soc. 1972, 94, 8229.

117. Dale, J. A.; Mosher, H. S. J. Am. Chem. Soc. 1973, 95, 512.

118. Oh, S. S.; Butler, W. M.; Koreeda, M. J. Org. Chem. 1989, 54, 4499-4503.

119. Husstedt, U.; Schafer, H. J. Tetrahedron Lett. 1981, 623-624.

120. McCarthy, J. R.; Huber, E. W.; Le, T. -B.; Laskovics, M.; Matthews, D. P. Tetrahedron 1996, 52, 45-58. 
121. (a) Itami, K.; Nokami, T.; Ishimura, Y.; Mitsudo, K.; Kamei, T.; Yoshida, J. -I. J. Am. Chem. Soc. 2001, 123, 11577-11585. (b) Andrei, D.; Wnuk, S. F. J. Org. Chem., 2006, 71, 405-408.

122. Robins, M. J.; Sarker, S.; Wnuk, S. F.; Nucleosides Nucleotides 1998, 17, 785790 .

123. (a) Zhang, X.; Burton, D. J. J. Fluorine Chem. 2001, 112, 47-54. (b) Xu, J.; Burton, D. J. J. Org. Chem. 2005, 70, 4346-4353.(c) Xu, J.; Burton, D. J. Tetrahedron Lett. 2002, 43, 2877-2879.

124. Hayashi, T.; Konishi, M.; Kobori, Y.; Kumada, M.; Higuchi, T.; Hirotsu, K. J. Am. Chem Soc. 1984, 106, 158-163.

125. Rabinowitz, R.; Marcus, R. J. Am. Chem. Soc.1962, 84, 1312-1313.

126. Van Leeuwen, P. W. N. M.; Kamer, P. C. J.; Reek, J. N. H.; Dierkes, P. Chem. Rev. 2000, 100, 2741.

127. Merget, M.; Bertermann, R.; Wagner, B.; Tacke, R. Organometallics 2001, 20, 3650-3654.

128. Bachmann, S.; Knudsen, K. R.; Jorgensen, K. A. Org. Biol. Chem. 2004, 2, 20442049.

129. Org. Synth. Coll. Vol. IV, pp.250-253.

130. Appell, R. B. Synth. Commun. 1995, 25, 3583-3587.

131. Chen, C.; Wilcoxen, K.; Zhu, Y. F.; Kim, K. I.; McCarthy, J.R. J. Org. Chem. 1999, 64, 3476-3482.

132. McCarthy, J. R.; Huber, E. W.; Le, T. B.; Laskovics, M.; Matthews, D. P. Tetrahedron 1996, 52, 45-58.

133. Gross, R. S. Synth. Commun. 1995, 25, 3583-3587.

134. (a) Xu, J.; Burton, D. J. Tetrahedron Lett. 2002, 43, 2877-2879.(b) Vanderhaar, R. W.; Burton, D. J.; Naae, D. G. J. Fluorine Chem. 1972, 1, 381-383.

135. Van Hamme, M. J.; Burton, D. J. J. Fluorine Chem. 1977, 10, 131-143.

136. Burton, D. J.; Greenlimb, P.E. J. Org. Chem. 1975, 40, 2796-2801.

137. Tamaru, Y.; Ochiai, H.; Nakamura, T.; Yoshida, Z. Tetrahedron Lett. 1986, 27, 955-958. 


\section{DANIELA ANDREI}

\section{$\underline{\text { Education }}$}

Ph.D. Candidate, Chemistry, Fall 2006, Florida International University, Dissertation:"Synthesis of multi- substituted halo-olefins via Pd-catalyzed crosscoupling reactions. Applications in nucleoside chemistry".

Advisor: Professor Stanislaw Wnuk.

M.S. Natural Products, "Gh. Asachi” Technical University, Iasi, Romania.

B.E. Biochemical Engineering, "Gh. Asachi” Technical University, Iasi, Romania.

\section{Honors \& Scholarships}

- Outstanding Organic Chemistry Teaching Assistant Award (2005-2006)

- SoFLACS Graduate Travel Award, 2006

- Graduate Students Scholarly Forum, FIU, Spring $2006-1^{\text {st }}$ place

\section{Publications}

1. Andrei, D.; Wnuk, S. F. "S-Adenosylhomocysteine Analogues with the Carbon-5' and Sulfur Atoms Replaced by a Vinyl Unit" Org. Lett. 2006, 8(22), 5093-5096.

2. Andrei, D.; Wnuk, S. F. "Synthesis of the Multisubstituted Halogenated Olefins via Cross-Coupling of Dihaloalkenes with Alkylzinc Bromides". J. Org. Chem. 2006, 71(1), 405-408.

3. Wang, M.; Zhang, J.; Andrei, D.; Kuczera, K.; Borchardt, R. T.; Wnuk, S. F. "Are LAdenosine and Its Derivatives Substrates for S-Adenosyl-L-homocysteine Hydrolase?" J. Med. Chem. 2005, 48(10), 3649-3653.

4. Popa, M. I.; Aelenei, N.; Popa, V. I.; Andrei, D. "Study of the interactions between polyphenolic compounds and chitosan". Reactive \& Functional Polymers 2000, 45(1), $35-43$. 


\section{Presentations at Conferences}

1. Andrei, D.; Wnuk, S. F."Synthesis of S-adenosylhomocysteine analogues via metathesis of 5'-deoxy-5'-methyleneadenosine analogues and homoallylglycine" Division of Carbohydrate Chemistry, $232^{\text {nd }}$ ACS National Meeting, San Francisco, CA, September 10-14, 2006.

2. Andrei, D.; Wnuk, S. F. "Negishi coupling of dihaloalkenes with alkylzinc bromides". $231^{\text {th }}$ ACS National Meeting, Atlanta, GA, March 26-30, 2006.

3. Andrei, D.; Gonzalez, A.; Wnuk, S. F. "Cross-coupling reactions of 1,1-dihalo-1with alkylzinc bromides". $229^{\text {th }}$ ACS National Meeting, San Diego, CA, March 13-17, 2005.

4. Wnuk, S. F.; Lalama, J.; Andrei, D.; Garmendia, C. A.; Robert, J."SAdenosylhomocysteine and S-ribosylhomocysteine analogues with sulfur atom replaced by the vinyl unit". $229^{\text {th }}$ ACS National Meeting, San Diego, CA, March 1317, 2005.

5. Lalama, J; Andrei, D.; Garmendia, C.A.; Wnuk, S. F. "Synthesis of S-ribosyl-Lhomocysteine analogues via trans-selective Negishi coupling of sugar-derived dihaloalkenes". 227 $7^{\text {th }}$ ACS National Meeting, Anaheim, CA, March 28-April 1, 2004.

6. Andrei, D.; Aelenei, N.; Popa, M. I; Costin, D. "Controlled release of drugs using carboxymethylcellulose-chitosan complex and polyvinylalcohol hydrogels". $3^{\text {rd }}$ International Symposium on Frontiers in Biomedical Polymers Including Polymer Therapeutics- From Laboratory to Clinical Practice, May 23-27, 1999, Shiga, Japan.

\section{Affiliations}

American Chemical Society

South Florida American Chemical Society. 